\title{
O NEGATIVO E O POSITIVO a fotografia entre os Asuriní do Xingu
}

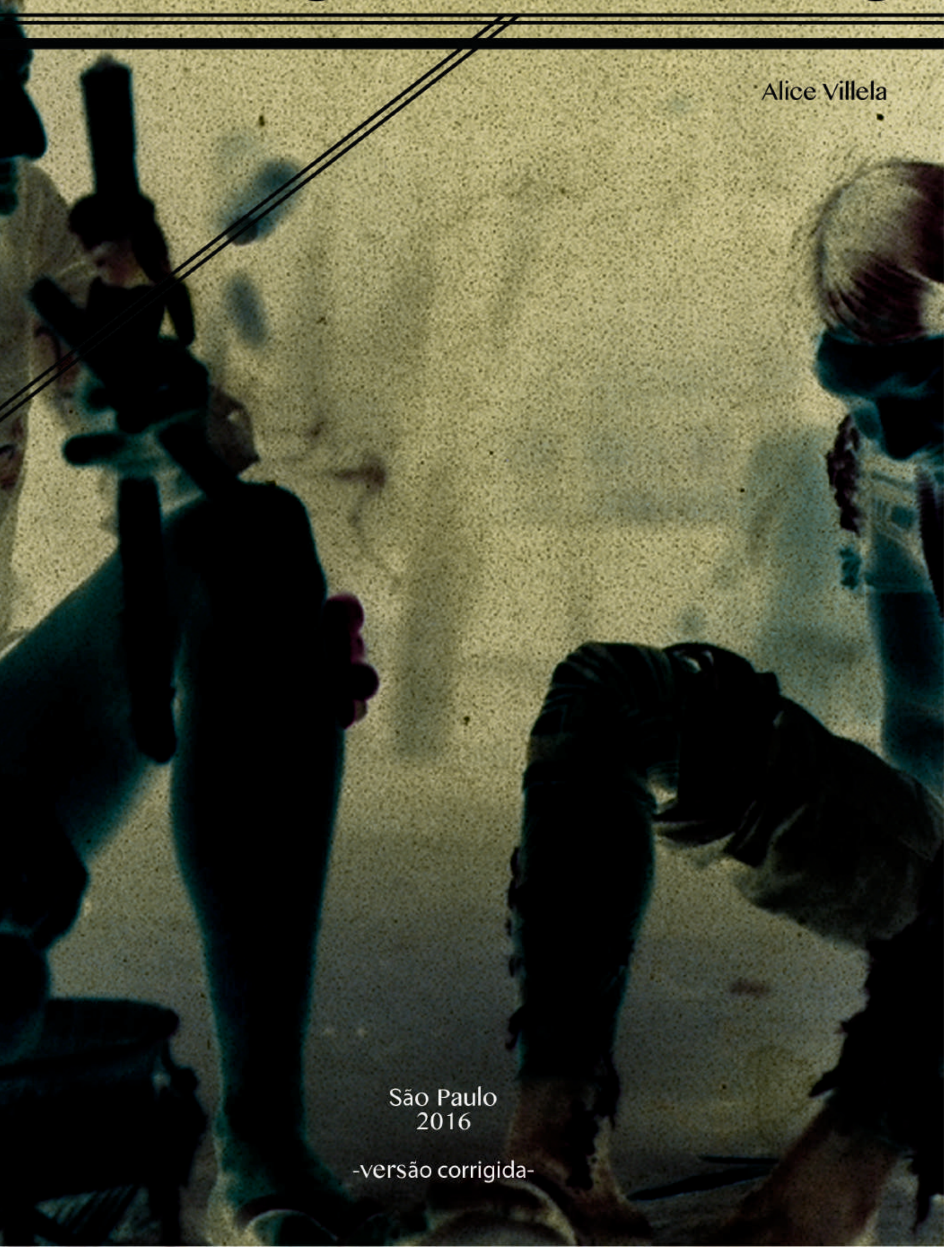


UNIVERSIDADE DE SÃO PAULO

FACULDADE DE FILOSOFIA, LETRAS E CIÊNCIAS HUMANAS

DEPARTAMENTO DE ANTROPOLOGIA

PROGRAMA DE PÓS-GRADUAÇÃO EM ANTROPOLOGIA SOCIAL

\title{
0 negativo e o positivo
}

\author{
a fotografia entre os Asuriní do Xingu
}

Alice Villela

Tese apresentada ao Programa de PósGraduação em Antropologia Social da Faculdade de Filosofia, Letras e Ciências Humanas da Universidade de São Paulo para obtenção do título de Doutor em Antropologia Social.

Orientador: Profa. Dra. Sylvia Caiuby Novaes

São Paulo

2016

- versão corrigida - 
Autorizo a reprodução e divulgação total ou parcial deste trabalho, por qualquer meio convencional ou eletrônico, para fins de estudo e pesquisa, desde que citada a fonte.

Catalogação na Publicação

Serviço de Biblioteca e Documentação

Faculdade de Filosofia, Letras e Ciências Humanas da Universidade de São Paulo

VV735n Villela, Alice

O negativo e o positivo. A fotografia entre os Asuriní do Xingu / Alice Villela ; orientadora Sylvia Caiuby Novaes. - São Paulo, 2016.

$$
248 \mathrm{f} \text {. }
$$

Tese (Doutorado)- Faculdade de Filosofia, Letras e Ciências Humanas da Universidade de São Paulo. Departamento de Antropologia. Área de concentração: Antropologia Social.

1. $\mathrm{CH} 764,1,16,2, \mathrm{CH} 764,1,3,4,3, \mathrm{CH} 741,11$. I. Caiuby Novaes, Sylvia, orient. II. Título. 
Para Hidalgo e Francisco 


\section{AGRADECIMENTOS}

Aos Asuriní do Xingu, pelos anos de convivência e aprendizado. Meu agradecimento especial a Marakauá e Mure'yra, por me permitirem entrar em suas vidas de forma tão generosa. A Koain, Koatireí, Parajuá e Takamuin, pelas conversas instigantes. A Murapijava, Parakakuja e Matuia, pelas conversas descontraídas e pelo acolhimento.

Aos companheiros de campo Fabíola Andrea Silva, a quem agradeço também o convite para participar da expedição ao igarapé Piranhaquara; a Clea e Sayonara, pelos momentos compartilhados; a Lucilene e Delma, pela companhia.

A minha orientadora Sylvia Caiuby Novaes pela disposição irrestrita, confiança e pela leitura deste trabalho em suas diferentes etapas. Devo a ela, também, o estímulo em trabalhar com imagens fotográficas, que não estava previsto no projeto de pesquisa inicial.

A Regina Müller, por ter me apresentado os Asuriní, e por ter me lançado no universo da antropologia das formas estéticas quando eu ainda era uma estudante de graduação. Minha gratidão por ter disponibilizado o acervo integral das fotografias de Renato Delarole, bem como outros materiais em que as fotos foram publicadas.

Aos colegas do Gravi - Grupo de Antropologia Visual e do Napedra- Núcleo de Antropologia, Performance e Drama, que propiciaram um ambiente intelectual vivo e estimulante. Ao Lisa- Laboratório de Antropologia Visual e a sua equipe, especialmente a Mariana Vanzolini (in memoriam) e Paula Morgado.

Ao Programa de Pós-Graduação em Antropologia Social, especialmente a Soraya Gebara.

À Fapesp, pela bolsa regular de pesquisa e pela bolsa de estágio de pesquisa no exterior, que me proporcionou uma experiência riquíssima em Paris.

Ao centro de pesquisa EREA - Enseignement et Recherche en Ethnologie Amérindienne, da Universidade de Nanterre, pela ótima recepção durante minha permanência no exterior. Aos meus supervisores Patrick Desahyes e Jean Pierre Chaumeil, pela recepção. A Bonnie Chaumeil, pela calorosa guarida. Jean Pierre 
forneceu valiosos comentários ao meu trabalho em seminário interno do grupo, ao que sou muito grata. Aos colegas David Jabin, pelas sugestões e conversas sobre a pesquisa, e a Íris Moraes Araújo, pela leitura de um dos textos apresentados durante essa estadia. Aos demais colegas e amigos com quem partilhei a vida acadêmica em Paris: Eduardo Pires Rossi, Ana Cecília Venci Bueno, Leandro Mahalem de Lima e Romain Bragard. Aos amigos Renata Franco, Carlos Valverde, Letícia Canelas, Paulo José de Lara, Seba Yahia e Esther Briso, que tornaram a vida fora do país muito agradável.

A Barbara Glowczewski, pela abertura e pelas conversas. Seu admirável trabalho junto aos povos aborígines e sua postura generosa são fontes de inspiração.

A Magda Ribeiro, companheira e amiga, antropóloga e mãe, com quem partilhei ideias e também afetos. A Vitor Grunvald, pela parceria acadêmica, pelas conversas e pelo compartilhamento de momentos intensos no fim da tese. A Rafael Hupsel pelas trocas de ideias sobre fotografia, magia e religião. A Sônia Lorenz por acompanhar minha caminhada acadêmica ainda que de longe.

A Francirosy Ferreira, que auxiliou na formulação do projeto de pesquisa inicial. A professora Dominique Gallois pelas preciosas sugestões no exame de qualificação. Aos professores presentes na banca de defesa da tese: Edgar Teodoro da Cunha, Rose Satiko, Regina Müller e Renato Sztutman, pela leitura atenta e curiosa. Renato acompanhou este trabalho em seus diferentes momentos fornecendo importantes contribuições, a ele um agradecimento especial. A professora Lux Vidal que, apesar de suplente, nos deu a honra de sua presença no momento da defesa oferecendo seus ricos comentários.

Aos amigos Júlio e Coraci, compadres queridos, pela força. A Alan Carneiro, Julinda Santana e a todos os outros amigos que estiveram por perto, pelo carinho e incentivo. Aos integrantes do bloco de samba Cupinzeiro, pelos valiosos momentos de alegria e música vividos nestes anos, momentos que foram fundamentais para a melhor fruição do trabalho.

A minha família, especialmente à Neusa, Luana e Marília, pelo apoio. A minha mãe, que forneceu suporte e condições de trabalho em diversos 
momentos. Ao meu pai, pela leitura cuidadosa e pela revisão do texto; sua retidão no trato com as palavras é sempre uma fonte de aprendizado e inspiração.

Por fim, gostaria de agradecer ao Hidalgo pelo amor e incentivo, pela parceria e pelo apoio incondicional durante todo o processo da pesquisa, e ao Francisco, que no início do doutorado era um bebê e agora é um menino, pela paciência e companheirismo em todos os momentos. 


\section{RESUMO}

O tema deste trabalho é a relação dos Asuriní do Xingu, grupo tupi que vive na margem direita do rio Xingu (Pará), com imagens produzidas pelas tecnologias dos brancos, especialmente as fotográficas. 0 que interessa é a maneira como essas novas imagens provocam agenciamentos e reflexões da perspectiva asuriní, ao dialogarem com conceitos nativos para o domínio da imagem tais como ynga e ayngava. A relação com as fotografias, entendidas aqui como imagens materiais, é abordada do momento do primeiro contato aos dias atuais. Se no encontro com os padres católicos a fotografia agiu de modo patogênico, causando doenças e mortes, nos dias de hoje ela pode ativar memórias e lembranças dos parentes falecidos, experiência que passa a ser vista de forma positiva pelos índios. Desse modo, procurou-se evidenciar que a relação dos Asuriní com imagens técnicas não é estanque, varia de acordo com o contexto histórico e, principalmente, conforme o tipo de relação que se estabelece com os seus produtores, os brancos. Não foi apenas como ferramenta de trabalho de campo que a fotografia se mostrou potente, mas se constituiu como um tema de pesquisa vigoroso ao possibilitar a abertura a diversos conteúdos asuriní ligados ao estatuto da imagem, à morte, ao xamanismo, à memória, às narrativas do contato, ao processo histórico e às mudanças pelas quais o grupo tem passado nos mais de quarenta anos de convívio intenso com os não-indígenas.

Palavras-chave: Asuriní do Xingu, fotografia, imagem, agência, brancos. 


\begin{abstract}
The subject of this work is the relationship developed by the Xingu Asuriní, a Tupi group living on the right bank of the Xingu River (Pará), with images produced by technologies of the non-indigenous, in particular, photographic. The study's emphasis is on the manner in which these new images provoke agency and reflections from the Asuriní perspective, in a dialogue with native concepts for the image domain, such as ynga and ayngava. The relationship with photos, understood here as material images, is dealt with from the moment of first contact to the present day. If in the encounter with Catholic priests photography functioned in a pathogenic way, causing illness and death, nowadays it can evoke memories of deceased relatives, an experience that has come to be seen in a positive light by indigeous people. Therefore, it can be seen that the Asuriní's relationship to images is not a restrictive one, but varies according to historical context and, in particular, is dependent on the type of relationship established with the non-indigenous producers of these images. It is not only as an instrument for field work that photography has demonstrated its power, but it has also become a subject for vigorous research by making possible the access to numerous Asuriní concepts related to the image, to death, shamanism, memory, stories of contact, to the historical process and to changes that the group has experienced in the more than forty years of intense interaction with nonindigenous people.
\end{abstract}

Keywords: Asuriní of Xingu, photography, image, agency, non-indigenous. 


\section{CONVENÇÃO ORTOGRÁFICA DAS PALAVRAS ASURINÍ 1}

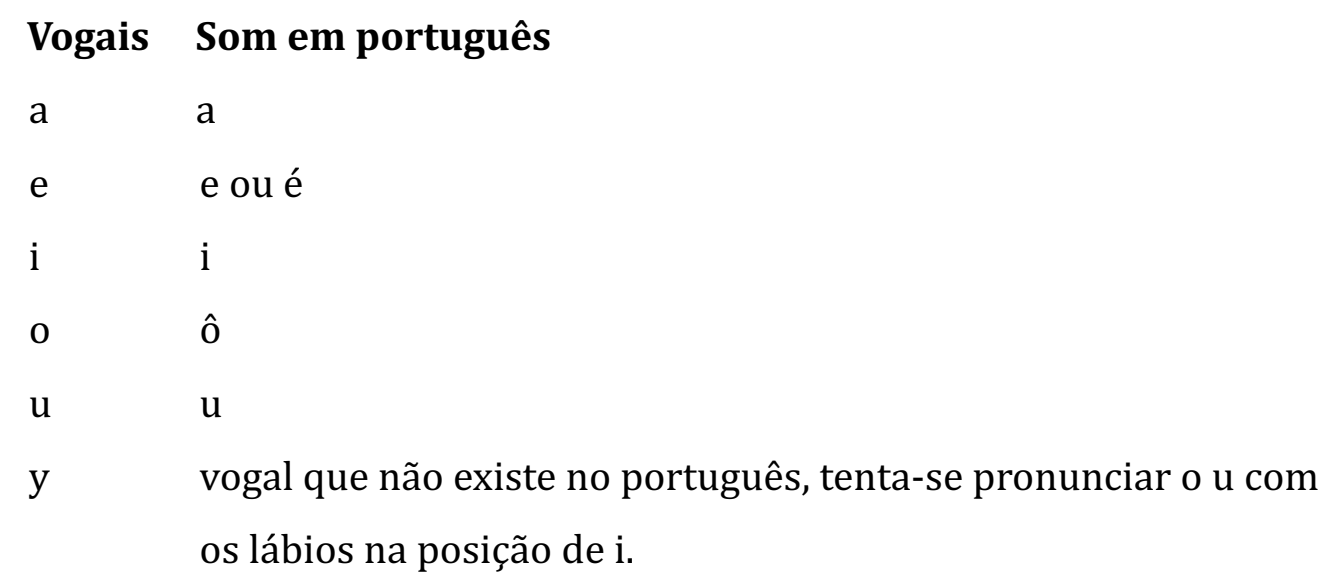

\section{Consoantes Som em português}

$\mathrm{b}$

como no espanhol caballo e como b do português

j dj, j, i, e nh

$\mathrm{k} \quad \mathrm{c}$

kw como qu no português quase

m $\quad \mathrm{me} \mathrm{mb}$

n n e nd

p pef

r r em cara

s tx ou $x$

$\mathrm{t} \quad \mathrm{t}$

V V v do português e w do inglês

' (apóstrofo) oclusiva glotal - uma parada súbita entre duas vogais vogais nasalizadas possuem til.

* Todas as palavras na língua asuriní estão em itálico, exceto nomes próprios (incluindo também lugares, espíritos e festas).

${ }^{1}$ Para a convenção que apresento me servi da sistemaização utilizada pela antropóloga Regina Müller, que contou com a colaboração do linguista Aryon D. Rodrigues, do Instituto de Estudos da Linguagem/ Unicamp. Ver Müller, 1993, p. 11. 


\section{LISTA DE IMAGENS}

\section{Introdução}

Imagem 1 - 27

Imagem 2 - 27

\section{Capítulo 1}

Imagem 1 - 55

\section{Capítulo 2}

Imagem 1 - 97

Imagem 2 - 115

\section{Capítulo 3}

Imagem 1 - 128

Imagem 2 - 133

Imagem 3 - 134

Imagem 4 - 136

Imagem 5 - 144

Imagem 6 - 145

Imagem 7 - 146

Imagem 8 - 148

Imagem 9 - 156

Imagem 10 - 158

Imagem 11 - 159

Imagem 12 - 162

Imagem 13 - 163

Imagem 14 - 164

Imagem 15 - 166

Imagem 16 - 168

\section{Capítulo 4}

Imagem 1 - 188

Imagem 2 - 188

Imagem 3 - 190

Imagem 4 - 193

Imagem 5 - 193

Imagem 6 - 196

Imagem 7 - 202

Imagem 8 - 208

Imagem 9 - 209

Imagem 10 - 214

Imagem 11 - 218

Imagem 12 - 219

Imagem 13 - 220

Imagem 14 - 223 


\section{LISTA DE PRANCHAS}

Introdução

Prancha 1 - 35

Prancha 2 - 36

\section{Capítulo 2}

Prancha 1 - 119

Prancha 2 - 120

\section{Capítulo 3}

Prancha 1 - 141

Prancha 2 - 151-155

Prancha 3 - 160

\section{Capítulo 4}

Prancha 1 - 189

Prancha 2 - 197-198

Prancha 3 - 199

Prancha 4 - 200

Prancha 5 - 204-205

Prancha 6 - 206-207

Prancha 7 - 215 


\section{SUMÁRIO}

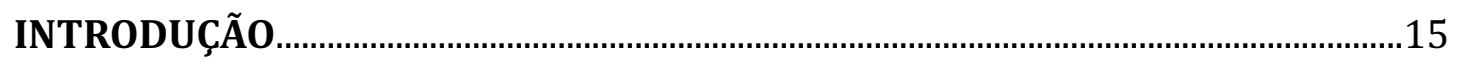

Os Asuriní do Xingu e a pesquisa de campo......................................................................24

CAPÍTULO 1 - NOÇõES DE IMAGEM E POSSIBILIDADES TRADUTIVAS................37

1.1. Problemas colocados pela imagem …………….................................................38

1.2. Trilogia ynga, ikwasiat e ayngava ……………..............................................46

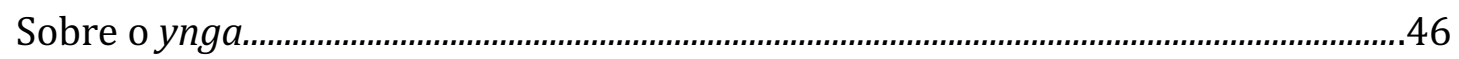

Ikwasiat, desenho ...........................................................................................................

Ikwasiat e tayngava, relações entre grafismo e figuração .............................................57

Ayngava, imitação e perigo.............................................................................................61

1.3. Termos, usos e apropriações das imagens técnicas...........................................66

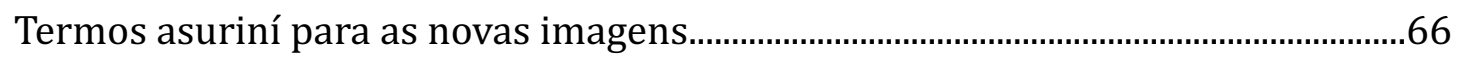

Usos, apropriações e reflexões suscitados pelo audiovisual...........................................72

CAPÍTULO 2 - A FOTOGRAFIA COMO OBJETO PATOGÊNICO....................................83

2.1. Agência, pessoa e imagem.....................................................................................87

2.2. A magia da fotografia ..........................................................................................

2.3. Consubstanciação do ynga entre pessoas, espíritos e imagens................ 97

Tayngava, um paradigma para a fotografia......................................................................97

Fluxos do ynga nos processos de cura e tratamento....................................................100

2.4. Brancos, feiticeiros e inimigos.........................................................................102

2.5. Os anhynga e a morte............................................................................................108

0 espectro anhynga e a desintegração da pessoa.........................................................108

Tavyve, vida e morte..............................................................................................................114

CAPÍTULO 3 - ENCONTROS E DESENCONTROS EM TORNO DA FOTOGRAFIA

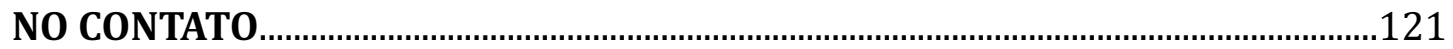

3.1. A fotografia no contato, um percurso de pensamento.................................122

Bearded Indians..., o livro...............................................................................................127

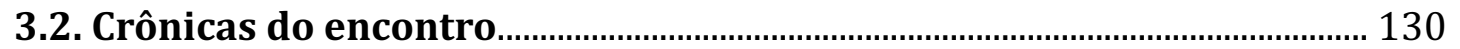

0 primeiro encontro com os índios barbados...............................................................131

0 dia em que um homem amansou os brancos.............................................................136 
3.3. Legendas e nomes, descrever e reconhecer

3.4. Barbas, poses e presentes.

CAPÍTULO 4 - 0 RETORNO DOS ANTIGOS: FOTOGRAFIAS DE RENATO

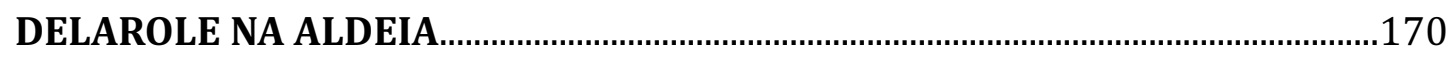

4.1. 0 retorno das fotografias como forma de abordagem..............................171

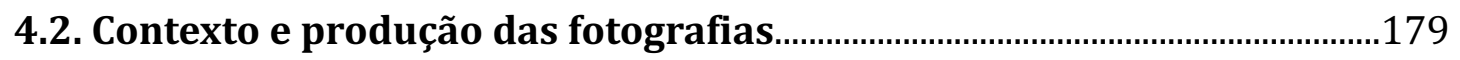

O acervo fotográfico de Renato Delarole......................................................................179

Idas e vindas: o percurso de Renato Delarole entre os Asuriní..................................180

Renato - fotógrafo na aldeia..........................................................................................182

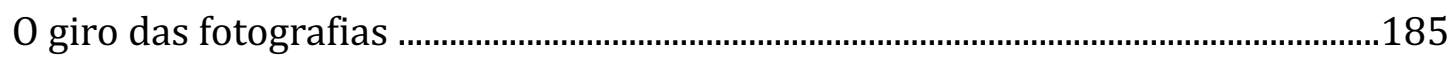

De volta, o retorno das fotografias...........................................................................190

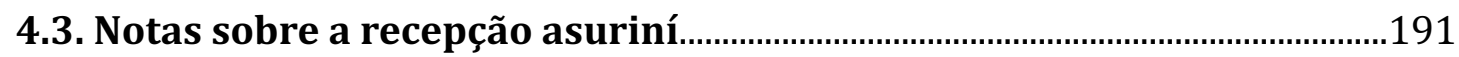

Lembranças de si, no tempo em que era nova ............................................................193

4.4. Ver e lembrar, a memória dos parentes..........................................................201

O album da Marakauá, o álbum do Mure'yra................................................................202

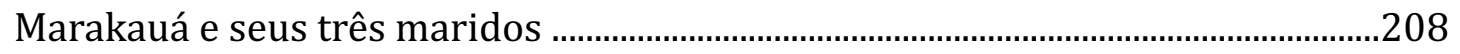

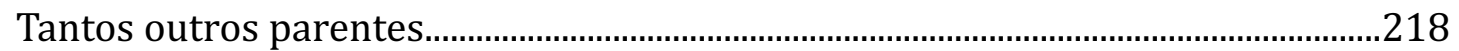

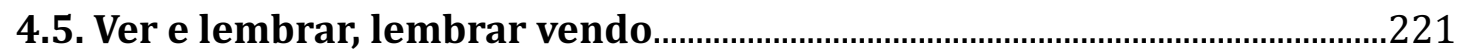

$\begin{array}{lllllllll}\text { CONSIDERAÇÕES } & \text { FINAIS } & - & 0 & \text { NEGATIVO } & \text { E } & 0 & \text { POSITIVO } & \text { EM }\end{array}$

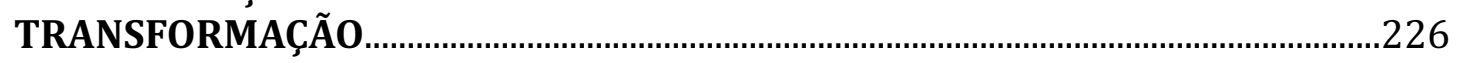

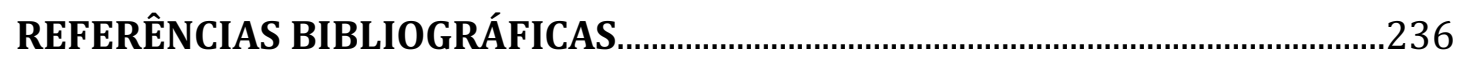

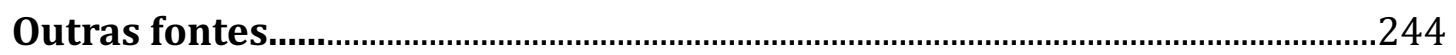

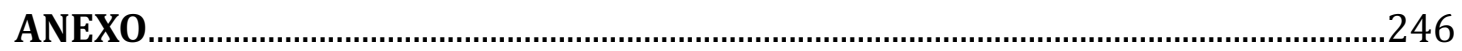



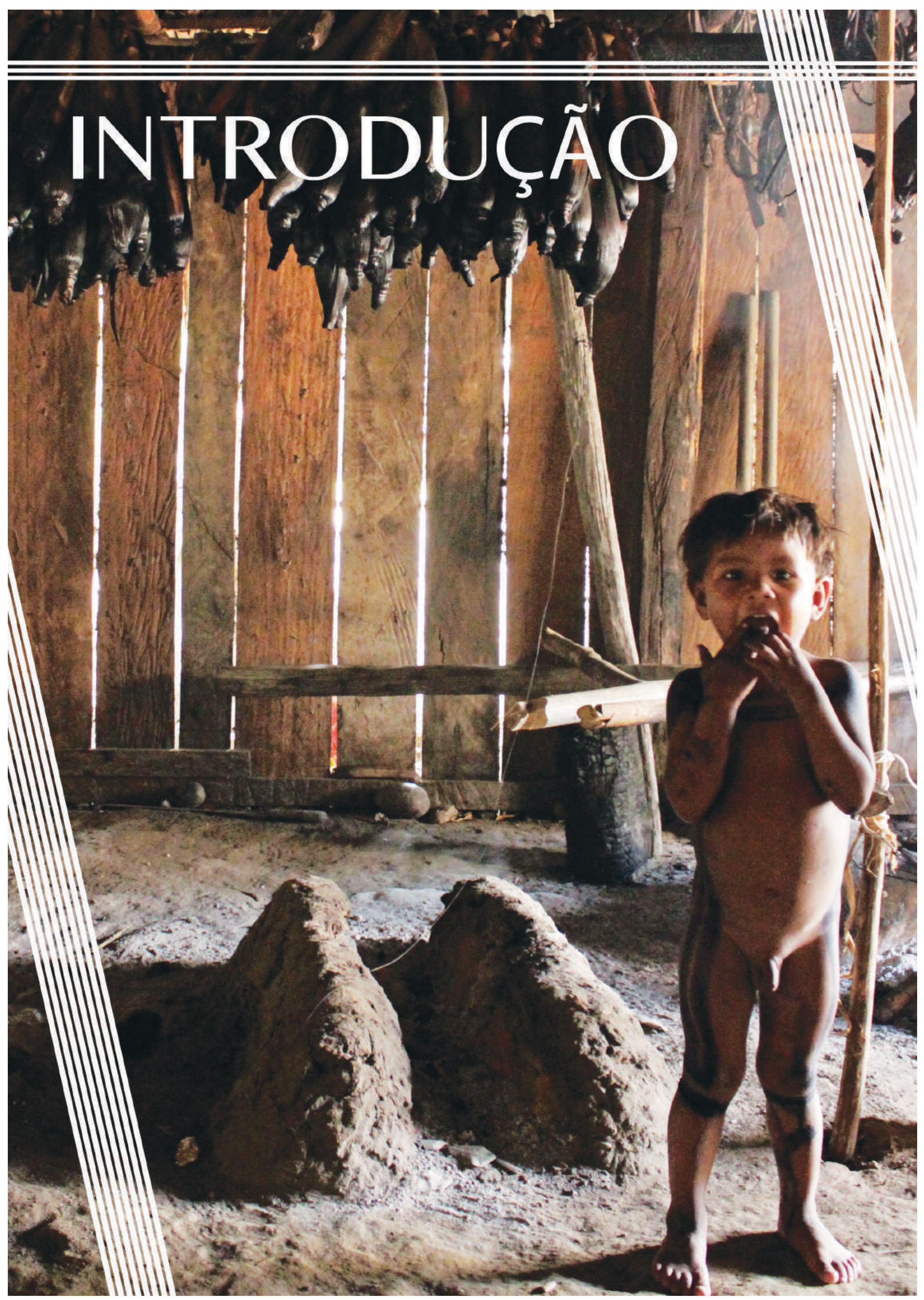


\section{INTRODUÇÃO}

Este trabalho trata da relação dos Asuriní do Xingu, povo tupi que vive na margem direita do rio Xingu no Pará, com imagens técnicas produzidas pelos brancos, especialmente as fotográficas. Do contato oficial até os dias atuais, o que nos interessa é a maneira como essas novas imagens provocam agenciamentos e reflexões ao dialogarem com conceitos nativos ligados ao domínio da imagem, tais como ynga (princípio vital) e ayngava (imitação, imagem).

Fotografias, aqui, são entendidas como imagens materiais. Isso significa não apenas que trabalhei exclusivamente com imagens produzidas por câmeras analógicas e impressas em papel, mas também que a opção de tomá-las como objetos consistiu em uma escolha teórico-metodológica, o que me possibilitou abrir um diálogo com alguns trabalhos antropológicos que discutem a agência das imagens e dos objetos.

Comecemos com alguns esclarecimentos a respeito da materialidade das fotografias utilizadas ${ }^{1}$. Os conjuntos fotográficos com que trabalho foram produzidos em dois momentos: na ocasião do contato oficial em 1971, quando os irmãos Lukesch registraram o primeiro encontro dos "civilizados" com os índios do Ipiaçava, e durante o período de 1976 a 1986, quando o fotógrafo Renato Delarole acompanhou a antropóloga Regina Müller em seu trabalho de pesquisa.

\footnotetext{
1 Todas as imagens reproduzidas nesta tese foram tratadas pelo artista visual Hidalgo Romero, a quem agradeço a parceria também na concepção e apresentação visual do trabalho. As fotografias utilizadas estão devidamente creditadas, a exceção das imagens que abrem os capítulos, a introdução e capa da tese; essas imagens são, na verdade, fotografias escolhidas dentre o conjunto analisado no trabalho com alguma intervenção gráfica. A imagem que abre a conclusão é a única que não aparece ao longo do texto. Trata-se de uma fotografia de minha autoria produzida em maio de 2015 durante estadia entre os Asuriní do Xingu. Tanto nessa imagem quanto na imagem da capa da tese, o que se dá a ver é o negativo da fotografia, efeito produzido intencionalmente.
} 
Portanto, ambos os conjuntos de imagens foram produzidos em uma época em que as câmeras digitais ainda não haviam sido popularizadas. 0 que isso implica na relação dos Asuriní com essas fotografias é que, entre a tomada de fotos e o momento em que as imagens se tornavam disponíveis, transcorria, geralmente, um tempo que era necessário não apenas para que o rolo do filme pudesse ser revelado, mas também para que as imagens pudessem retornar aos Asuriní, via os próprios produtores ou por intermédio de outras pessoas.

Na prática, apenas um índio disse se lembrar das imagens produzidas por Anton Lukesch, que foram publicadas em 1976 no livro Bearded indians of the tropical forest, e um maior número deles já havia visto as fotografias de Renato Delarole, que tiveram circulação mais ampla por estarem associadas ao trabalho de Regina Müller - que desde 1976 retorna freqüentemente 2 à área indígena. Ainda assim, os Asuriní disseram nunca ter visto todas as fotos de Delarole pois, de fato, o volume do material é grande; são mais de 700 imagens.

Obtive as informações mencionadas acima por ocasião do meu último trabalho de campo realizado entre os meses de maio e junho de 2015, quando circulei os dois conjuntos de imagens em impressões em papel fotográfico (tamanho $15 \mathrm{~cm} \times 21 \mathrm{~cm}$ ). Embora todas as fotografias já estivessem disponíveis em suporte digital, a opção por levar fotos em papel me conferiu maior agilidade para o trabalho na aldeia - local onde usar computador nem sempre é fácil.

No início da pesquisa, quando questionei os Asuriní a respeito da presença da fotografia no episódio do contato, a resposta corrente associou a captura de fotos às mortes e aos adoecimentos que ocorreram nos anos subseqüentes. Os Asuriní não tinham memória das imagens em si, mas dos efeitos que a tomada de fotografias teria gerado no primeiro encontro com os padres católicos. 0 esforço em compreender o que eles estavam me apontando, ao dizerem que a fotografia tirou o ynga das pessoas fotografadas, levou-me a

\footnotetext{
${ }^{2}$ Nesta tese, optei pelo uso do trema. A escrita, como definida desde os gregos que consolidaram o alfabeto por volta do século VI a.C., compromissa-se em reproduzir a língua falada. Acresce que a tal "reforma" recente da língua brasileira atendeu apenas a conveniências da indústria editorial, com ênfase para a de livros didáticos. Falar de uma forma mas escrever consequência é inconseqüência.
} 
explorar as relações que podiam ser estabelecidas entre ynga (princípio vital) e ayngava (imitação, imagem).

A ideia de que a fotografia pode "tirar" o ynga do retratado e, portanto, estabelecer novas relações com a pessoa ao compartilhar o seu princípio vital, impôs-se com tamanha luminosidade no início da investigação que não tive outra opção a não ser persegui-la. Assim, toda a primeira parte deste trabalho se desenvolveu em torno da ideia da fotografia como objeto patogênico.

A ênfase asuriní na ação da fotografia me levou a trabalhos que problematizam as relações entre a clássica separação entre pessoas e objetos, ou pessoas e coisas. Há, na teoria antropológica contemporânea, um crescente interesse pela agência das imagens bem como pela "vida dos objetos" 3 , debate que, pelo menos no campo da antropologia da arte, teve a importante contribuição de Alfred Gell (1998). No caso das artes ameríndias, há diversos estudos que trabalham nesta perspectiva, por exemplo, os trabalhos de Lagrou (2007), Barcelos Neto (2008) e Van Velthem (2003), que abordam temas como a corporalidade, a agência dos objetos e o estatuto ontológico da arte para os ameríndios. Uma discussão mais recente sobre figuração levada adiante por Descola (2006, 2010), e também por Taylor (2010), Lagrou e Severi (2013), parece enfatizar a presença de artefatos num universo povoado por agências passíveis de serem conhecidas, que muitas vezes fazem a mediação entre o invisível e o que é visível para os homens comuns.

Longe de pretender dar à fotografia o estatuto de um artefato envolvido nas tramas do xamanismo e das artes que tradicionalmente os Asuriní realizam, a exemplo dos autores citados acima, o que faço é me beneficiar dessa discussão para pensar o caso das imagens técnicas. Me parece ser este um caminho não muito usual quando o assunto pertence ao domínio da subárea da antropologia visual. Encontrei poucos estudos publicados que abordam usos e agências de fotografias entre povos indígenas. Sem dúvida, o trabalho de Silvia Pellegrino (2008) é pioneiro neste sentido. A autora aborda as imagens fotográficas entre os Wajãpi, e o sangue entre os Yanomami, como vínculos de pertencimento em relação aos saberes e memória de cada povo. Além dos possíveis paralelos

\footnotetext{
${ }^{3}$ Ver, por exemplo, a coletânea A vida social das coisas. Appadurai, 2008 [1986].
} 
quanto à compreensão do que sejam imagens fotográficas, há, no trabalho de Pellegrino, a menção clara dos Wajãpi de que a fotografia pode ser utilizada em práticas de feitiçaria, argumento que trago para pensar o caso asuriní.

Durante estágio de pesquisa no exterior em Paris, França ${ }^{4}$, tive contato com o texto "Retoucher les morts, les usages magiques de la photographie en Mongolie", escrito por Georges Delaplace (2014), uma leitura curta e instigante. Explorando relações entre fotografia e magia, o autor trata das fotografias mortuárias, fabricadas a partir de fotos de cédulas de identidade coloridas e ampliadas, que são exibidas nos funerais na Mongólia, e que depois ficam expostas recebendo oferendas. Em mongol, como entre os Asuriní, os termos utilizados para designar uma fotografia significam também "alma" ou "sombra". A ação de tirar uma foto é referida pelo termo "tirar a sombra".

Ainda sobre fotografia e morte, José de Souza Martins comenta a reação dos velhos Tapirapé diante das fotografias de seus parentes que ilustram o livro de Herbert Baldus, quando receberam um exemplar muitos anos depois de publicado. Diante das imagens, os Tapirapé choraram o pranto ritual próprio da sua cultura no reencontro com os parentes falecidos. Martins afirma que:

\begin{abstract}
A imagem fotográfica, nessa reação, revela-se como suporte inesperado de um imaginário poderoso, vivo, na função do imagético no imaginado e na memória, como documento interior de pertencimento, e não como documento exterior de ciência e de uma modalidade objetiva de conhecimento social (Martins, 2008, p.154).
\end{abstract}

A concepção da fotografia como coisa viva, comum a diversos povos ameríndios, não sustenta apenas a construção da ideia de objeto com ação patogênica, argumento apresentado na primeira parte deste trabalho, mas se estende aos demais capítulos, quando trato da circulação das imagens de Anton Lukesch e de Renato Delarole entre os Asuriní atuais. Nessas ocasiões, fotografias

\footnotetext{
${ }^{4}$ Junto ao EREA - Enseignement et Recherche en Ethnologie Amérindienne do LESC Laboratoire d'Ethnologie et de Sociologie Comparative, CNRS - Centre National de la Recherche Scientifique, Université Paris Ouest Nanterre La Défense. O que foi possível graças à bolsa de Estágio de Pesquisa no Exterior Bepe - Fapesp (Proc. 2013/07177-3), com vigência de 01/09/2013 a 30/06/2014.
} 
agem no sentido descrito por José de Souza Martins, ativando um imaginário poderoso e avivando a memória, apresentando-se como "documento interior de pertencimento". Parentes falecidos retornam via imagens e memória e, neste momento, a potência da fotografia não esteve direcionada no sentido negativo, elas evocaram positivamente as lembranças vividas na relação com os "antigos".

Entre os Asuriní, o estatuto vivo das imagens, incluindo aí as novas imagens, tem sua base no xamanismo como forma de pensar e conhecer o mundo. Não é nada estranho que os termos que são empregados para se referirem às imagens técnicas apontem para ações de "guardar" e "capturar" o ynga, atividades que empreende o xamã nos rituais xamanísticos. Narrativas e prescrições presentes no cotidiano asuriní indicam que nem tudo pode ser imitado sem efeitos pois, aqui, estamos longe de uma ideia de representação como "imitação da aparência"; antes, a imitação está associada à partilha de qualidades e à evocação de propriedades do original. Objetos que imitam, como o tayngava, boneco antropomórfico utilizado nos procedimentos de cura, são dotados de agência poderosa e por isso perigosa, e sua manipulação, restrita aos xamãs em contextos rituais. Desta maneira, o estatuto da imagem asuriní estaria próximo ao regime das imagens na Grécia Antiga, em que ídolos gregos, tais como descreve Vernant (1990[1973]), "presentificam o invisível" (mortos e deuses), e da ideia de mimesis de Taussig (1993), em que o objeto que imita captura as qualidades e o poder do original.

O trabalho desta tese se inicia ao ajustar o foco analítico e metodológico em vias de ir ao encontro de noções de imagem da perspectiva asuriní. Que ideia de imagem estaria sendo operacionalizada por mim ao lançar mão do termo para compreender o domínio ameríndio? A partir do reconhecimento de que a palavra imagem pode ser uma cilada, procurei problematizar seu uso e suas possibilidades tradutivas. Em vias de conhecer o que seja o domínio da imagem entre os Asuriní, investigo alguns conceitos nativos, quais sejam, ynga, ayngava e ikwasiat, que se referem ao princípio vital, duplo, sombra, imitação, imagem e desenho. Neste momento, valho-me da etnografia de Müller, que estudou a fundo a arte gráfica asuriní, além do trabalho de outros autores que pensam conceitos ameríndios ligados ao "princípio vital animado" (Viveiros de Castro, 1986; e 
Garcia, 2010) e à figuração na arte ameríndia (Lagrou, 2013; Descola, 2006; Taylor, 2010, dentre outros). A partir daí, é possível chegar aos termos que eles empregam para se referir às novas imagens, bem como alguns usos e agenciamentos a elas relacionados. Todo esse percurso é realizado no primeiro capítulo que, de certa maneira, objetiva ordenar, pelo menos um pouco, o aparente caos em que se fazem presentes múltiplos entendimentos sobre o que seja imagem, num contexto de pesquisa intercultural.

São inúmeras as ressonâncias entre o que imagens fotográficas provocam entre os Asuriní e o que teóricos da fotografia já haviam notado como especificidade deste tipo de imagem técnica. Para citar um exemplo, em diferentes momentos ao longo da história asuriní pós-contato, as fotografias têm o mesmo poder de evocar o retratado. A presença do referente é mencionada por Dubois (2014[1990]) como o aspecto indicial e a "pregnância do real na fotografia". Barthes, em uma de suas obras dedicadas à fotografia (1984), afirma ser a aderência do referente à imagem a característica que distingue a fotografia de todas as outras formas de produção de imagem. E ainda, Bazin vai falar em "transferência de realidade da coisa para a sua reprodução" (1991[1945], p. 22). Aproximações entre o que pensam os Asuriní e teóricos da fotografia existem, o que não me leva a supor que estejam falando a mesma coisa. Semelhança icônica e implicância indicial são notadas e formuladas à sua maneira pelos índios. Dubois ficaria contente em ver que os Asuriní notaram o aspecto indicial da fotografia, mas não porque eles conhecem o processo técnico de impressão luminosa, e sim porque está implícito no domínio da imagem asuriní que um objeto representa partilhando qualidades com o modelo.

A identidade entre a imagem fotográfica e o referente não remete, da perspectiva asuriní, de modo algum à ideia de objetividade. Neste ponto, a semelhança perfeita evoca sobretudo relações com a magia, como uma forma de especulação sobre a realidade. Como bem foi notado por Caiuby Novaes, "[a]lém da enorme semelhança entre a imagem e o real que ela representa, na fotografia o referente adere à imagem tal como nas práticas mágicas, em que se supõe que qualquer elemento que tenha tido contato com uma pessoa possa, pelo contágio, remeter a ela" (2008, p. 462). Em um tipo de regime ontológico em que objetos 
podem ser dotados de intencionalidade ou estarem imersos em redes personificadas de relações, não é nada inusitado que a fotografia possa adquirir agência e atuar sobre corpos de pessoas. Este é o tema do capítulo dois, que explora a ideia da fotografia como objeto patogênico e suas relações com a magia, com o xamanismo (destaque para o objeto tayngava), com a morte, com a desintegração da pessoa, além da exploração da ideia de que os brancos podem ser considerados alteridades causadoras de malefícios.

Mais uma camada é agregada à análise ao considerarmos a dimensão da mudança na relação com imagens fotográficas ao longo do tempo. 0 modo como os Asuriní entendem a fotografia não é estanque, muda de acordo com o contexto e com as diferentes relações travadas com os seus produtores, os brancos. Sem pretender realizar um trabalho exaustivo acerca das diversas situações com que os Asuriní foram confrontados com a fotografia desde o contato, escolho pontos neste período que me parecem significativos para pensar a compreensão dessas imagens de uma perspectiva nativa.

Ao tentar entender por que mudam as narrativas dos índios a respeito da fotografia no contato, deparei-me com a maneira como os Asuriní interpretam e constroem sua própria história, ao produzirem discursos internos sobre o passado. Como aponta Gow (2006), que busca compreender as narrativas dos nativos do Baixo Urubamba, os discursos internos ao grupo são construídos a partir do que é significativo para eles, contrapondo-se à história externa construída a partir de documentos e vidência. Neste sentido, inspirada em Gow, que busca levar a sério o que os nativos fazem e dizem, creio ser produtivo partir da ideia de que as variações nos discursos sobre a fotografia no contato são dados significativos para os Asuriní.

De certa forma, mudanças e transformações - demográficas, na estrutura social, e mais amplamente no modo de vida asuriní - estão o tempo todo aparecendo quando o tema são as novas imagens e, por isso, acredito que pensar a relação dos Asuriní com essas imagens ao longo do tempo pode nos ajudar a compreender a continuidade da cultura asuriní, por meio dos modos específicos pelos quais ela se transforma, para falar nos termos de Sahlins (1997). No entanto, é preciso que se diga que a história asuriní não está no centro da análise, 
é antes um tema que decorre do problema central relacionado à fotografia, funcionando como um pano de fundo para a reflexão que se pretende construir.

O que me possibilitou verificar a diversidade de discursos sobre a agência da fotografia no contato, bem como o modo como esse tipo de imagem atua nos dias de hoje, foi a circulação dos conjuntos fotográficos que já foram mencionados. Anton Lukesch fotografou os Asuriní na margem direita do igarapé Ipiaçava, e as quase 70 imagens publicadas em 1976 acompanham um texto em que o autor apresenta uma descrição da expedição, além de considerações sobre o modo de vida asuriní, formuladas a partir de algumas semanas de convivência com o grupo. Renato Delarole fotografou os Asuriní na aldeia Koatinemo Velho nas margens do Ipiaçava de 1976 a 1985, e também na aldeia Avasikirera, onde os índios permaneceram um curto espaço de tempo entre 1985 e 1986.

Tanto as fotos de Lukesch como as de Delarole foram chamadas de bavarayngava, em que bava se refere aos "antigos" (Asuriní que já morreram), na tradução que fazem para o português, e ayngava, à imagem (e imitação). Creio que ao chamar as fotografias de bavarayngava era aos parentes mortos retratados nas imagens que eles estavam se referindo ${ }^{5}$. As relações que se estabeleceram com as imagens dos "antigos" passam pelos vínculos de parentesco; fotografias lhes possibilitaram ver e lembrar dos parentes (jeretá, meu parente). 0 modo como explorei esse fenômeno, que sucedeu em campo, foi apontar para a potencialidade e a positividade da fotografia em afirmar laços e vínculos de pertencimento, ao trazer memórias do passado. Seria tema de um outro trabalho identificar como são constituídos os parentes e exatamente que parentes são lembrados por quem. 0 parentesco foi um tema bem pouco explorado entre os Asuriní; apenas Müller (1993) se dedicou a ele, ainda assim como tópico em segundo plano e pano de fundo para suas análises acerca da arte gráfica e do xamanismo. Uma atualização desse estudo com novos dados está

\footnotetext{
${ }^{5}$ No mito do desenho, os bava são mencionados de uma maneira similar. Na versão contada por Burí e traduzida por Matuia (registrada por mim em novembro de 2012), Anhyngavuí, que aprendeu a arte gráfica passando para o trançado os desenhos do corpo de seu tio, Anhyngakwasiat, ensinou o trançado com desenhos aos bava (asuriní que já morreram) e estes ensinaram de pai para filho. Na transcrição que faz do mesmo mito, Müller (1993, p. 253) traduz bava por "mortos". Neste trabalho, opto pela tradução de bava por "antigos", pois é esse o termo em português usado correntemente pelos Asuriní.
} 
para ser feita, o que seria bastante interessante, haja vistas as mudanças nos arranjos matrimoniais e a existência de diversos casamentos interétnicos.

Enquanto as fotografias de Delarole evocaram lembranças de situações vividas junto às pessoas retratadas, expressas em narrativas de cunho pessoal, as fotos de Lukesch despertaram histórias do evento do contato. Obtive algumas versões a respeito do momento preciso da chegada dos padres e de sua equipe e, em todas elas, chamou-me atenção a ênfase ao homem que teria amansado os brancos. 0 xamã que sonhou e amansou os brancos chamava-se Avona, e as memórias do contato a ele associadas foram evocadas por uma fotografia específica de Lukesch em que ele é retratado.

0 tema do "amansamento" dos brancos não é novidade. A coletânea Pacificando o branco, publicada em 2000, nos mostra que o leitmotiv da "pacificação dos brancos" é recorrente entre diversos grupos indígenas, bem como o enigma do perigo de estabelecer relações sociais e trocas materiais com estes "selvagens", que associam à equação branco - espíritos maléficos e ao tema das epidemias como a fumaça letal emanada de suas mercadorias ${ }^{6}$. Entre os Asuriní, o desafio do contato mobiliza um intenso trabalho simbólico e político relacionado ao convívio com esses novos interlocutores.

O terceiro capítulo desta tese aborda os encontros e os desencontros de concepções e entendimentos entre os Asuriní e os padres em torno da fotografia no contato. Apresento o relato do contato na versão publicada por Anton Lukesch (1976) ao lado de suas fotografias, e as narrativas asuriní que se produziram no encontro dos índios com as fotos dos padres, mais de quarenta anos depois. 0 objetivo do capítulo é construir uma narrativa fotográfica do contato informada por versões de padres-etnólogos e dos índios. Tais narrativas por vezes se contrapõem a, ao mesmo tempo que revelam, que fotografias funcionam como mediadoras de relações entre índios e brancos. Se as fotografias são as mesmas,

\footnotetext{
${ }^{6}$ Diversos outros estudos foram desenvolvidos no sentido de debater como as diferentes populações indígenas vêm se transformando a partir do encontro colonial e, ao mesmo tempo, reagindo diante do processo de globalização e da força do sistema capitalista. Ver, além de Albert \& Ramos (Orgs.), 2000, Wright, 2005 e Gordon, 2006.
} 
seus usos são bastante distintos: os padres as empregam como evidências de que o contato foi pacífico, e os Asuriní as utilizam como artefatos da memória.

O quarto capítulo aborda os efeitos da circulação do acervo das mais de 700 imagens produzidas por Renato Delarole. Servindo-me de memórias, relatos, reações e reflexões que são engendradas e produzidas a partir do contato com as fotografias, procuro mostrar que novos usos das imagens dos antigos são possíveis de acordo com o momento histórico atual. Ao abordar, principalmente, a reação dos velhos e suas memórias provocadas pelas imagens, procuro trazer seus relatos para evidenciar que o que as fotografias fizeram, de forma potente, foi fazê-los lembrar dos antigos com afeto. No âmbito da tese, o último capítulo nos permite reconhecer o movimento e a oscilação que a fotografia percorreu entre os Asuriní, de patogênica, perigosa, maléfica e inconveniente a uma ação positiva, construtiva, profícua, e benéfica, sem deixar de ser, no entanto, potencialmente perigosa - o que nos ensina o manifesto perigo das fotografias dos recém-falecidos.

Os Asuriní do Xingu e a pesquisa de campo

Os Asuriní do Xingu vivem em duas aldeias localizadas na margem direita do médio rio Xingu, estado do Pará, na Terra Indígena Koatinemo ${ }^{7}$. São falantes do asuriní, língua que pertence à família tupi-guarani. Além dos Asuriní, outros cinco grupos ocupam o bloco de terras localizadas no médio Xingu: Araweté (T.I. Araweté / Igarapé Ipixuna), Parakanã (T.I. Apyterewa), Kararaô (T.I. Kararaô), Xikrin do Bacajá (T.I. Trincheira Bacajá) e Arara (T.I. Cachoeira Seca / T.I. Arara).

0 nome Asuriní vem do Asonéri, que quer dizer "vermelho" na língua juruna, denominação dada desde o século XIX aos índios que dominavam a região entre os rios Xingu e Bacajá, segundo o etnógrafo Curt Nimuendajú (1948). A autodenominação do grupo é Avaeté, que significa "gente de verdade" (ava= gente, eté $=$ verdadeiro) .

7 Área de 387.834,2501 ha, homologada em 1996. Fonte: DAF/Funai. 
As primeiras referências aos Asuriní do Xingu datam do fim do século XIX, de acordo com relatos de Nimuendajú (1948, p. 225) e Coudreau (1977 [1897], p. 32), que registraram ataques do grupo indígena a regionais na região da praia Grande, acima da boca do rio Bacajá, em 1894, e na região da serra do Passahy e da praia Grande, em 1896.

Localização da Terra Indígena Koatinemo

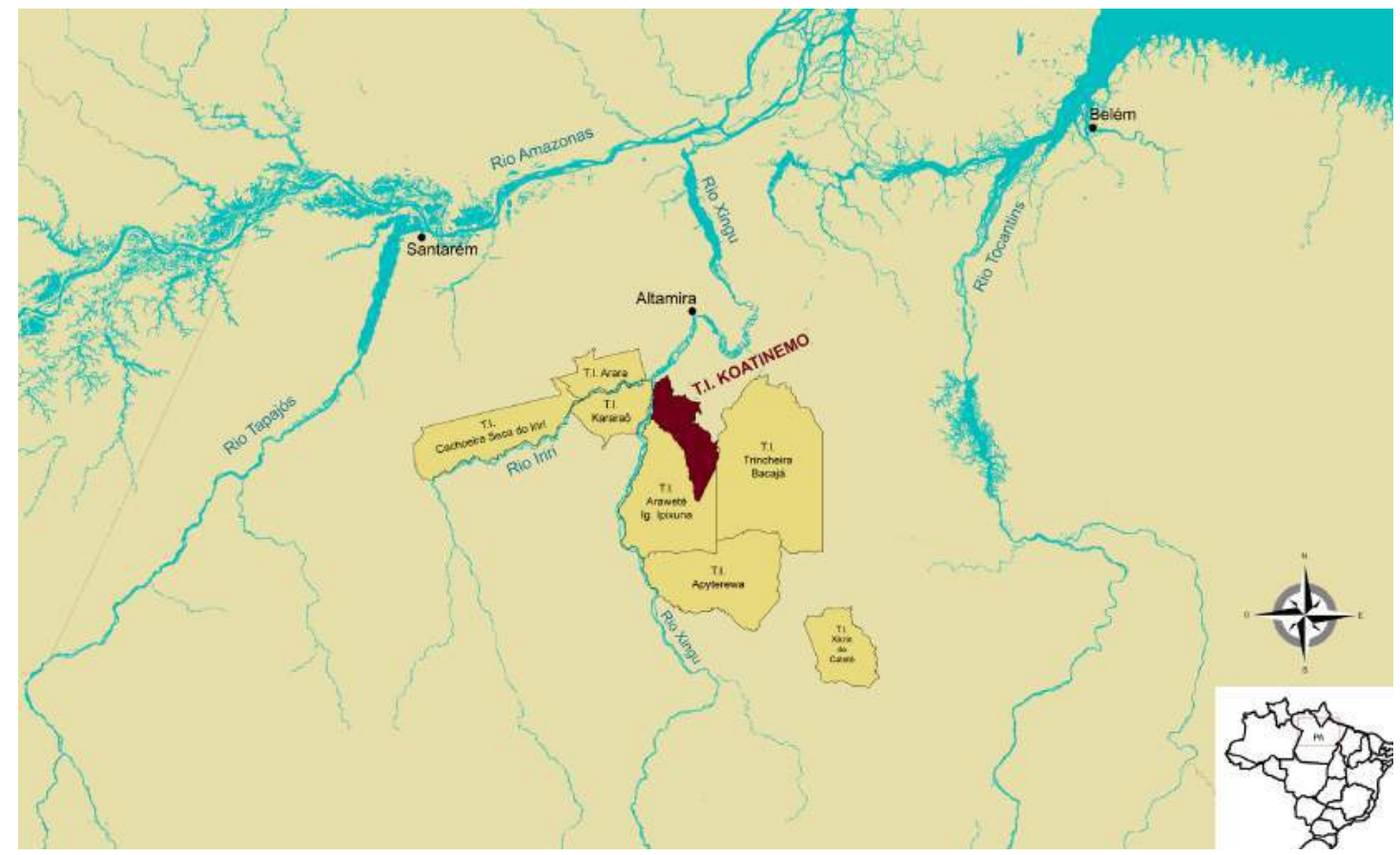

Na boca do igarapé Bom Jardim, os Asuriní mataram outro regional, em 1932. Nesse período, o grupo indígena deslocou-se da margem do rio Bacajá para oeste, nas cabeceiras dos igarapés Ipiaçava e Piranhaquara, fugindo de ataques de regionais, provavelmente extratores de caucho, cuja exploração era uma das principais atividades econômicas da sociedade nacional da região (Müller, 1993, p. 37). Em 1936, os Asuriní foram atacados pelos índios Gorotire (subgrupo Kayapó) durante sua expansão em direção ao norte, o que forçou o seu deslocamento para as margens do rio Ipixuna, onde permaneceram até 1960 (Nimuendajú, 1948).

Entre 1960 e 1970, intensificaram-se os conflitos intertribais entre os grupos Xikrin, Araweté e Asuriní. Em 1966, foram atacados pelos Xikrin do Bacajá, outro subgrupo Kayapó (Op. cit., p. 225) e, ainda nessa década, sofreram ataques dos Araweté, denominados por eles como Ararava. Desalojados das 
margens do igarapé Ipixuna pelos inimigos, foram obrigados a retornar para as cabeceiras dos igarapés Ipiaçava e Piranhaquara, e continuar a manter relações de hostilidade com os não-indígenas do entorno. Em encontros rápidos e fugidios, os Asuriní saqueavam os acampamentos dos brancos - que entravam nos afluentes da margem direita do Xingu para a caça ao gato selvagem e extração da seringa - para obter artigos de metal (facões, machados, etc.). No entanto, no final da década de 1960, parte do grupo decide estabelecer contato com os brancos que se encontravam no Ipiaçava, em busca de aliados para fazer frente às investidas dos inimigos, o que expande a localização das aldeias para seu limite máximo ao norte (Müller, 1993, p. 36).

$\mathrm{Na}$ década de 1970, intensificou-se a presença dos brancos com a finalidade de contatar os grupos indígenas da região, em decorrência do surgimento de novas atividades econômicas: mineração, agropecuária e projetos do governo, e em especial a construção da rodovia Transamazônica (BR-230). Os Asuriní ficaram encurralados entre inimigos tradicionais (os Xikrin, na margem do Bacajá, e os Araweté, nas margens do igarapé Ipixuna) e os brancos, que os alcançavam pelo Xingu e afluentes da margem direita. Entre os inimigos, de quem levavam desvantagens nos últimos anos, e os brancos, que deixavam presentes e pareciam não atacá-los, “[...] os Asuriní não tiveram outra saída senão aceitar a convivência com estes para pôr fim ao estado de guerra que os vinha debilitando há vários anos" (Müller, 1993, p. 40). Foi então que dois padres católicos austríacos, Anton e Karl Kukesch, contratados pela empresa Meridional Consórcio United States Steel Curd, que estava interessada na extensão da província ferrífera dos Carajás até a margem direita do Xingu, encabeçaram o programa de "pacificação" dos indígenas.

Após o contato, os Asuriní juntaram-se em uma única aldeia, chamada Koatinemo Velho, às margens do Ipiaçava, onde permaneceram até 1985, quando foram deslocados para a foz desse igarapé formando a aldeia Avasikirera, e depois para a confluência do igarapé com o Xingu, onde permanecem até hoje. Há cinco anos os Asuriní se concentravam em uma única aldeia, quando Koain, líder de um grupo doméstico, resolveu fundar um novo aldeamento na margem direita do Xingu, ainda mais perto da cidade de Altamira. Foi então que se formou a 
aldeia Ita'aka, que abriga hoje um pouco menos da metade da população total; são 57 pessoas nesta aldeia e 137 na aldeia do Koatinemo, totalizando 194 índios.

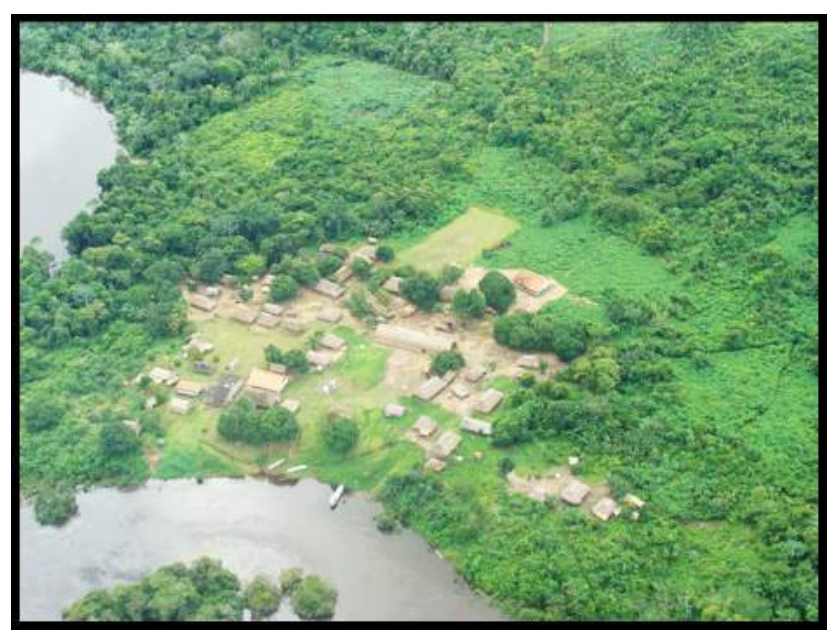

Imagem 1

Vista aérea da aldeia Koatinemo. Destaque para a casa grande ao centro da aldeia. Fonte: EIA-Rima Belo Monte, 2009.

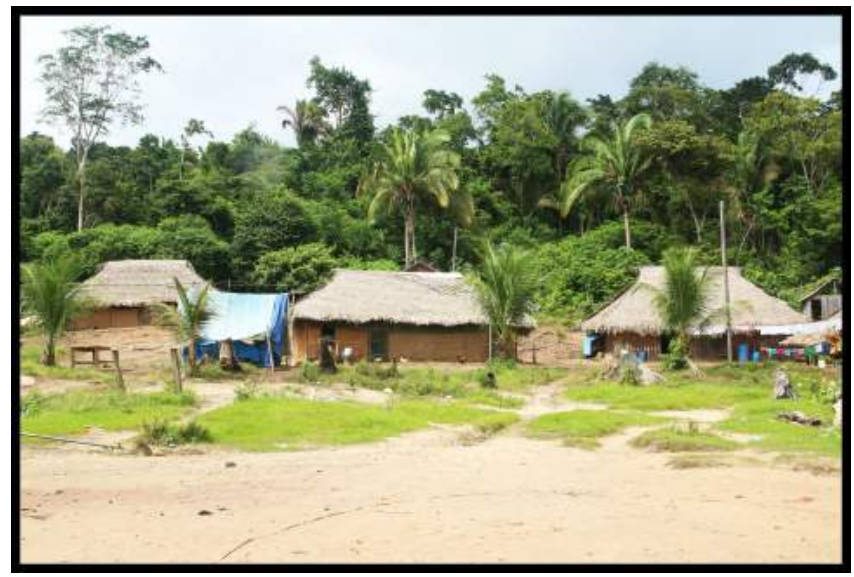

Imagem 2

Vista da aldeia Ita'aka. Foto: Alice Villela, maio de 2015

A partir de informações dos Asuriní e da antropóloga Berta Ribeiro (1982), em 1930, a população somava aproximadamente 150 indivíduos. Desta época até 1971, iniciou-se um processo de decréscimo populacional, resultado dos ataques dos grupos inimigos e do controle da natalidade. Na seqüência, o extenso contato com os brancos deu início a um traumático processo de redução demográfica; muitas mortes foram ocasionadas por gripe, tuberculose e epidemias de malária. Entre 1971 e 1982, a população Asuriní passou de 100 
indivíduos para 52 (Müller, 2002, p. 190). Em meados da década de 1980, os Asuriní iniciaram um processo de recuperação demográfica, com incremento da taxa de natalidade, que se estende até os dias atuais ${ }^{8}$.

Em 2006, ocasião em que realizei pesquisa de campo para o mestrado, a população somava 122 indivíduos, 65 mulheres e 57 homens (Cf. Villela, 2009). Na ocasião, anotei que pouco mais de dois terços da população (96 pessoas) tinha até 20 anos, e que o número de crianças (até 10 anos) correspondia a quase metade (63 crianças) da população total. No ano do contato, a população infantil representava apenas 7,8\% do total de 100 indivíduos e, em 1985, correspondia a aproximadamente 15\% de um total de 53 indivíduos (Müller, 1984-85, p. 95).

Em minha última ida ao campo no primeiro semestre de 2015 , a população Asuriní contava com 104 mulheres e 90 homens, incluídas aí quatro mulheres Parakanã e duas Munduruku, que se casaram com homens Asuriní, já tiveram filhos e residem nas aldeias asuriní. Atualmente a população de crianças (0-10 anos) soma 88 pessoas, quase metade da população total, em contraste ao reduzido número de velhos: entre as duas aldeias são 13 pessoas com 60 anos ou mais. Tal disparidade pode ser mais bem visualizada na figura seguinte, em que apresento a distribuição da população atual por faixas de idade.

Distribuição da população asuriní por faixas de idade em 2015.

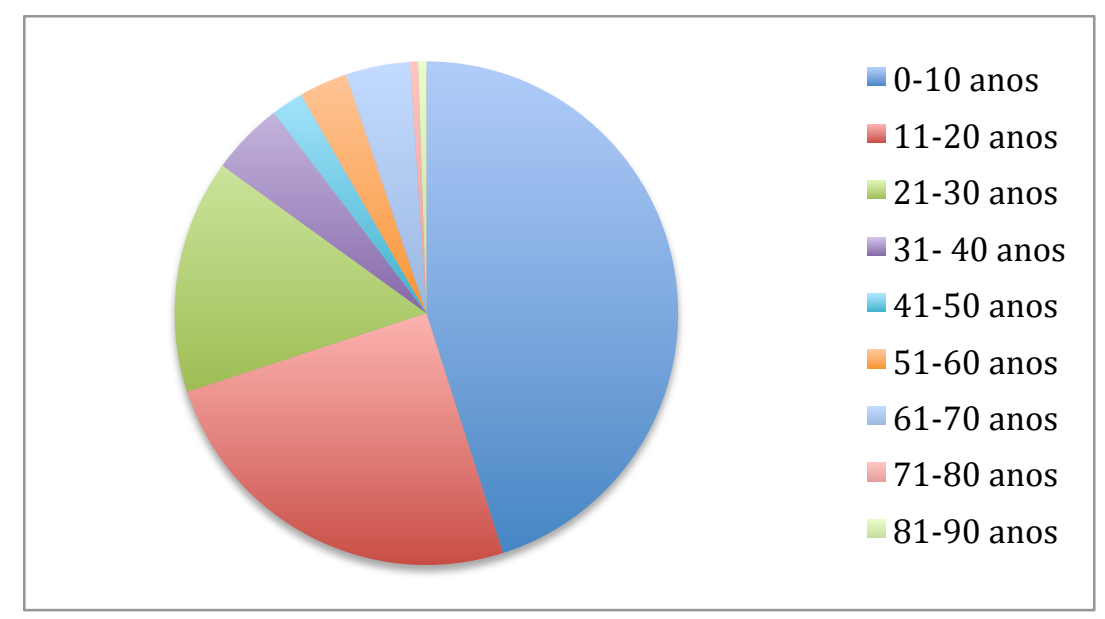

Fonte: Dados de campo.

\footnotetext{
${ }^{8}$ Em 1990, a população Asuriní somava 56 indivíduos; em 1996, passou para 79; em 2002 o número saltou para 105; e hoje conta com 194 pessoas. Fonte: Funasa/ Ministério da Saúde.
} 
O tema da demografia foi bastante explorado pela literatura sobre os Asuriní. Diversos estudiosos, entre eles Berta Ribeiro (1982, 1984-85), Regina Müller (1993, 2002) e Xanda Miranda (2014), mencionam as mudanças nos padrões de casamento e de procriação, incluindo as práticas de contenção ou não da natalidade. Miranda (2014), que centrou sua dissertação de mestrado sobre as criancas Asuriní, afirma que, a respeito da narrativa demográfica, a literatura asuriní pode ser dividida em dois momentos: o primeiro cunhado de "gerontocrático", caracterizado pelos estudos relacionados à notável contenção demográfica, e o segundo, de "infantocrático", identificado pela ausência desta contenção, que se inicia nos anos 1980 com o processo de recuperação demográfica.

A respeito das regras de casamento e das categorias de parentesco, Müller afirma que, quando chega aos Asuriní em 1976, o decréscimo populacional póscontato não permitiu que ela pudesse realizar estudos e descrições como "tradicionalmente vinham sendo realizadas pela antropologia". 0 que observa em seu período de estudo é que as regras de casamento estavam baseadas na diferença de idade e não em categorias de parentesco, além da distinção de sexo. Idade e sexo operam conjuntamente nas regras de casamento e estão, portanto, relacionados à formação dos grupos domésticos, definidos como “[...] unidade básica da estrutura social tanto por ser uma unidade social e política (tradicionalmente identificada com o grupo local) quanto por suas atividades de subsistência" (Müller, 1993, p. 64). 0 casamento geracional, ou seja, com cônjuges de duas gerações, podia ser realizado tanto na forma poligínica quanto na poliândrica. A ênfase na uxorilocalidade garantia a permanência de mulheres parentes entre si num mesmo grupo doméstico, e o casamento entre gerações garantia a permanência de um grupo de homens também relacionados pelo parentesco consangüíneo. Assim, uma posição de prestígio $^{9}$ estava relacionada ao

\footnotetext{
${ }_{9}^{9}$ Segundo Müller, o modo tradicional de chefia entre os Asuriní estaria relacionado ao sentido tradicional tratado na bibliografia tupi-guarani, "[i]sto é, o sogro que atrai para si homens, através do casamento uxorilocal com as filhas e exerce, assim, sua liderança" (Müller, 1993, p. 60). Ainda a respeito da liderança entre os Asuriní, eu mesma teci algumas considerações em outro trabalho ao afirmar que "[o] padrão político tradicional é caracterizado pela independência dos grupos domésticos, liderados por um homem, geralmente um xamã. No entanto, embora o xamã ocupe posição de grande prestígio, a chefia também é definida circunstancialmente conforme a atividade a ser exercida, como
} 
número de pessoas que um homem conseguia atrair e conservar no grupo, entre eles irmãos e filhos, sendo o casamento poliândrico e geracional uma possibilidade de manter, por exemplo, um filho consigo.

O crescimento demográfico, segundo Müller (2002), ocorreu com transformações nas práticas tradicionais e na organização social, observadas em 1976, como a alteração do grupo familiar pelo aumento de filhos na família nuclear e o abandono integral das antigas práticas de controle de natalidade, caracterizando o que a antropóloga chama de "maternidade ampla e irrestrita" (Müller, 2002, p. 192). Observou-se, também, o decréscimo no número de adultos e velhos, o que implicou o desaparecimento de muitos xamãs e líderes de grupos domésticos.

A figura seguinte apresenta a evolução demográfica entre os Asuriní de 1930 aos dias atuais.

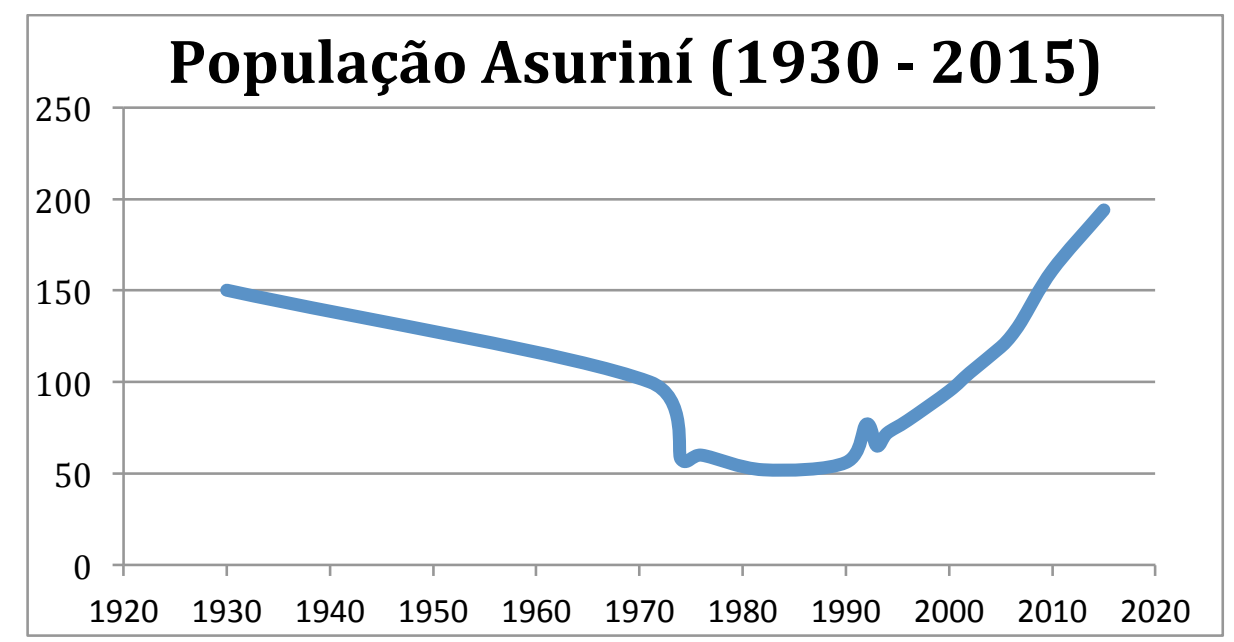

Fonte: Funasa, Berta Ribeiro (1982), Müller (2002) e dados de campo.

A presença massiva de crianças nas aldeias nos dias atuais tem implicações diretas sobre o tipo de experiência de campo que se pode ter entre os Asuriní. Quem realiza trabalho em aldeias sabe que as crianças são a porta de entrada na vida indígena pela curiosidade e espontaneidade com que se aproximam do pesquisador de fora. No caso Asuriní não é diferente, com a especificidade de que de mim elas se aproximavam aos bandos. Algumas crianças se tornaram 
importantes companheiras, principalmente durante as atividades cotidianas que a subsistência na aldeia exige, tais como lavar roupa, tomar banho no rio, tratar um peixe, salgar uma carne de caça, e também no tempo livre que eu tinha entre uma conversa e outra em torno das fotografias com os velhos asuriní.

Embora eu tenha trabalhado com acervos fotográficos de terceiros, não deixei de levar, em todas as idas a campo, uma câmera fotográfica, e foi entre as crianças que a presença da câmera provocou as reações mais interessantes. Elas não apenas se deixavam fotografar como propunham jogos para que eu participasse com o equipamento. Pediram-me, por exemplo, que registrasse a chegada de uma corrida para saberem quem realmente foi o vencedor. Em outra situação me solicitaram que fotografasse seus saltos de uma pedra na beira do Xingu, para que elas pudessem ver a si próprias nas imagens, ou então, simplesmente me levavam para andar na aldeia e se ofereciam para o retrato. A prancha 1 apresenta algumas dessas situações vividas nas aldeias com as crianças ${ }^{10}$.

O trabalho de campo para a pesquisa de doutorado realizou-se por meio de três incursões à área indígena, com períodos grandes entre uma e outra, totalizando três meses e meio de permanência. A primeira viagem realizou-se em outubro e novembro de 2012; a segunda, em abril e maio de 2013; e a terceira, entre os meses de maio e junho de 2015.

Na segunda ocasião, em parte dos dias de trabalho de campo, acompanhei a expedição às aldeias antigas ao longo do igarapé Piranhaquara junto à equipe de arqueólogos do MAE- Museu de Arqueologia e Etnologia da Usp coordenados pela Profa. Dra. Fabíola Andréa Silva11. A expedição durou 17 dias e contou com a participação de 98 Asuriní, metade da população. Além da colaboração com a equipe de arqueólogos por meio de filmagens, meu interesse particular na viagem

10 Parte dessas fotos integrou o ensaio Kunumi, exposto durante o Encontro Internacional de Antropologia Visual - EIAV ocorrido entre os dias 3 e 8 de novembro de 2014 na Usp.

${ }^{11} \mathrm{~A}$ expedição foi uma das atividades do projeto "Território e memória dos Asurini do Xingu: arqueologia colaborativa na T.I. Kuatinemu, Pará", e teve apoio da Fapesp (Processo 2012/51312-0). 
consistiu na possibilidade de conhecer um pouco mais a respeito da história asuriní, já que as aldeias ocupadas ao longo do Piranhaquara foram habitadas antes do contato. Além disso, pude ouvir um pouco mais a respeito dos anhynga, espectros dos mortos, tema que certamente viria à tona pois uma das evidências das aldeias antigas são os esteios da casa grande e seus cemitérios (avytera), onde estão enterrados os antigos Asuriní, além dos cacos de cerâmica e da capoeira, que indica mata secundária crescendo no local de uma antiga aldeia.

Para os Asuriní, e também para mim, as incursões ao campo são uma continuidade do trabalho com o grupo indígena, iniciado em 2006. Neste ano, viajei pela primeira vez à área indígena para levar gravações de cantos, vídeos e fotografias do acervo pessoal de Regina Müller sobre os Asuriní que haviam sido recém-digitalizados por edital do Instituto do Patrimônio Histórico Artístico Nacional - Iphan ${ }^{12}$. As fotografias eram, inclusive, as de Renato Delarole que retomo neste trabalho. Em 2007, permaneci durante dois meses na aldeia Koatinemo para acompanhar e filmar o ritual Apykwara, meu tema de pesquisa, trabalho que rendeu uma etnografia da performance ritual (Ver Villela, 2009), apresentada no mestrado pelo Programa de Pós-Graduação em Artes da Unicamp e em um documentário ${ }^{13}$ sobre a experiência no ritual.

Ao acompanhar os Asuriní nos últimos dez anos noto que as coisas mudaram velozmente. Um dos agentes dessas alterações do cotidiano indígena e da paisagem da aldeia é o complexo hidrelétrico Belo Monte. Entre a realidade que encontrei em 2012 e a que vi em 2015 há um hiato. Em junho de 2010 começou a ser construída a usina, nas cidades de Altamira, Vitória do Xingu e Senador José Porfírio (PA), e, embora nenhum dos grupos índigenas do médio Xingu tenham tido suas terras alagadas, os impactos socioeconômicos são enormes.

Apenas rapidamente, as principais diferenças que observei em 2015 em relação a períodos anteriores foram visitas mais frequentes à cidade de Altamira,

12 Trata-se do projeto "Documentação e Transmissão dos Saberes Tradicionais dos Asuriní do Xingu", patrocinado pelo Iphan por meio do edital de apoio ao Patrimônio Imaterial de 2005. O projeto digitalizou o acervo pessoal da antropóloga Regina Müller que conta com mais de 1.000 fotografias (negativos, positivos, contatos e ampliações), 50 horas de áudio (K7 e rolo) e 100 horas de vídeo (Super 8, Betacam e VHS) com registros de cantos, rituais, técnicas de confecção de objetos, atividades de subsistência e o cotidiano da aldeia desde a década de 1970.

13 Trata-se do filme Acontecências (23', DVD, cor, 2009), que dirigi com Hidalgo Romero. 
aumento significativo do consumo de bens e produtos (roupas, alimentos industrializados, ferramentas, voadeiras, televisores, DVDs, aparelhos de som, etc.) e aumento do consumo de bebidas alcoólicas. Tudo isso é financiado por recursos que entram nas aldeias provenientes de negociações diretas com a Norte Energia ${ }^{14}$, os chamados "acordos de canteiro"15, além de montantes do Plano Emergencial ${ }^{16}$, bolsa família, bolsa maternidade e aposentadorias.

O cotidiano nas aldeias durante os três trabalhos de campo era sempre marcado pela chegada e partida de múltiplas equipes do PBA, da Funai, da Funasa, ou da Norte Energia. Lideranças jovens e professores indígenas estavam a todo tempo sobrecarregados de atividades, reuniões e viagens para a cidade. Não raro eu tinha que marcar com antecedência uma conversa ou atividade com os mais jovens, com o risco de ser desmarcada, haja vista a agitada agenda deles. Assim, o dia a dia na aldeia era sempre bastante movimentado, muito distante do que se imagina seja um trabalho de campo em uma aldeia na Amazônia.

0 ritmo frenético alcançou seu auge em minha última viagem em 2015 quando, além das múltiplas equipes de trabalho, estavam presentes em cada aldeia cerca de 30 peões, um encarregado de obra, uma cozinheira, caminhões, tratores, e muito cimento e areia. Uma das ações de infraestrutura oferecida pela Norte Energia consiste na construção de casas para moradias nas aldeias e, diferentemente de outros povos, que escolheram receber habitações de madeira, os Asuriní optaram pelas residências de alvenaria. Em maio e junho de 2015 a equipe da obra estava finalizando as casas no Koatinemo e iniciando as residências no Ita'aka.

\footnotetext{
${ }^{14}$ A Norte Energia S. A. é uma empresa de capital misto que venceu o leilão realizado em 20 de abril de 2010 de concessão para a construção da hidrelétrica e exploração do potencial hidrelétrico por um prazo de 35 anos. Mais inofrmações: http://norteenergiasa.com.br.

15 Exigências feitas pelas lideranças indígenas para a desocupação dos canteiros de obra da construção da UHE Belo Monte, invadidos como estratégia de reivindicação.

${ }^{16}$ Listas de bens indiscriminadamente oferecidos às populações indígenas atingidas pelo empreendimento eram feitas pelos indígenas compreendendo desde alimentação, higiene pessoal e vestimenta, a combustível, embarcações e motores, eletrodomésticos, etc, em lugar de projetos de etnodesenvolvimento, previstos num Plano Emergencial exigido pela Funai à NE, até que se iniciassem os programas do PBA-CI - Plano Básico Ambiental - Componente Indígena do processo de licenciamento ambiental para construção e operação da obra.
} 
De fato, a mudança na paisagem das aldeias com as casas de alvenaria é qualquer coisa colossal. No período em que realizei o trabalho de campo eles ainda não tinham se mudado para as novas casas e, portanto, as casas antigas de palha e barro não haviam sido destruídas. Na prancha 2 apresento algumas fotografias com as novas e as velhas habitações, e são novamente as crianças que me mostram suas casas antigas e as recém-adquiridas. Em passeios pela aldeia elas me mostraram onde cada família irá morar e, com o mesmo entusiasmo, apresentaram-me suas casas antigas e as novas.

Embora as crianças não estejam presentes ao longo da tese, é com elas que gostaria de abrir este trabalho e, neste momento, apenas destacar sua atitude espontânea e receptiva em relação à câmera fotográfica, muito distante do que pode sugerir a ideia da fotografia como objeto patogênico manifesta no pós contato. 
prancha 1

\section{Criancas Asuriní}
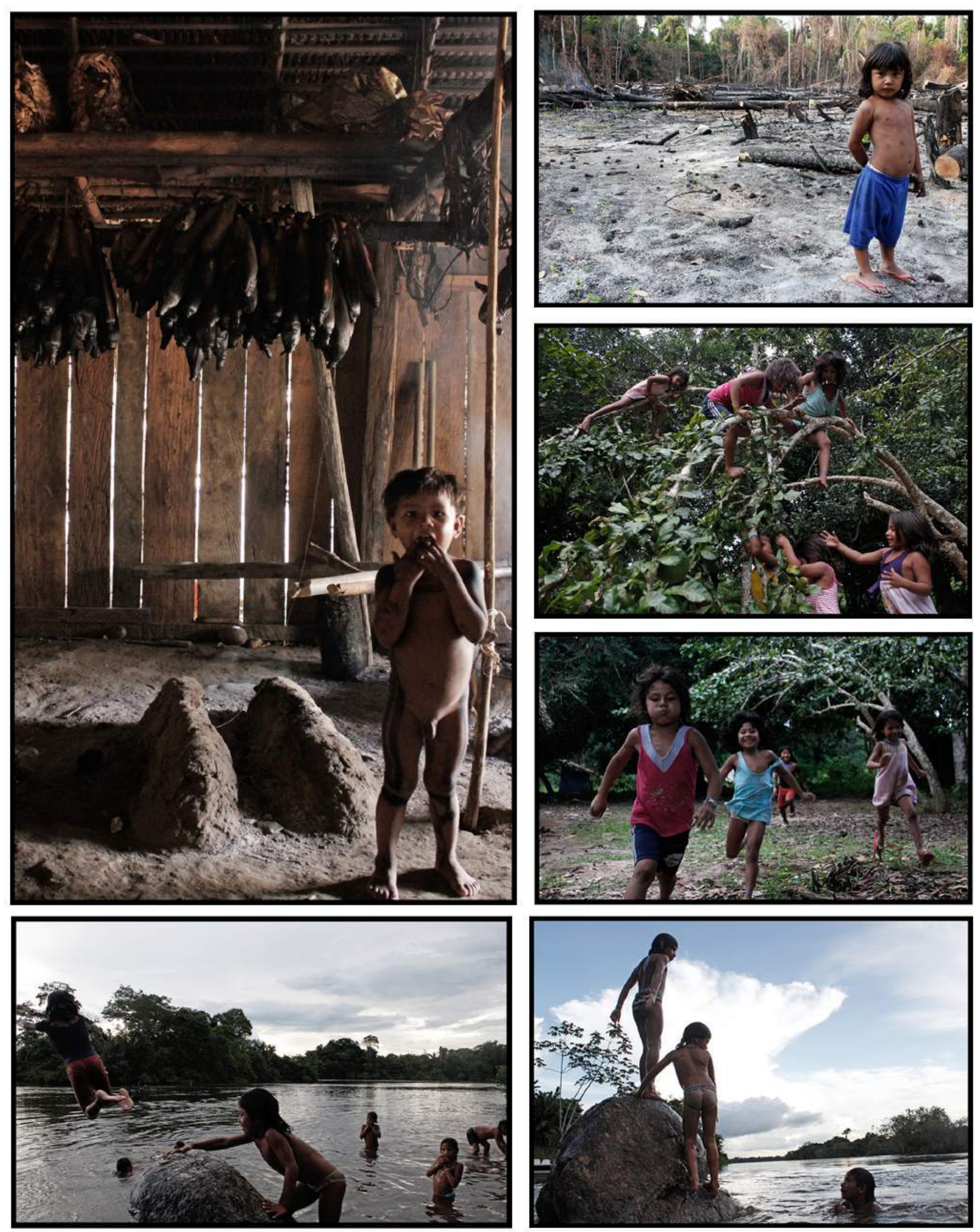

Fotos: Alice Villela 


\section{prancha 2 Antigas e novas habitaçöes}

Fotos: Alice Villela

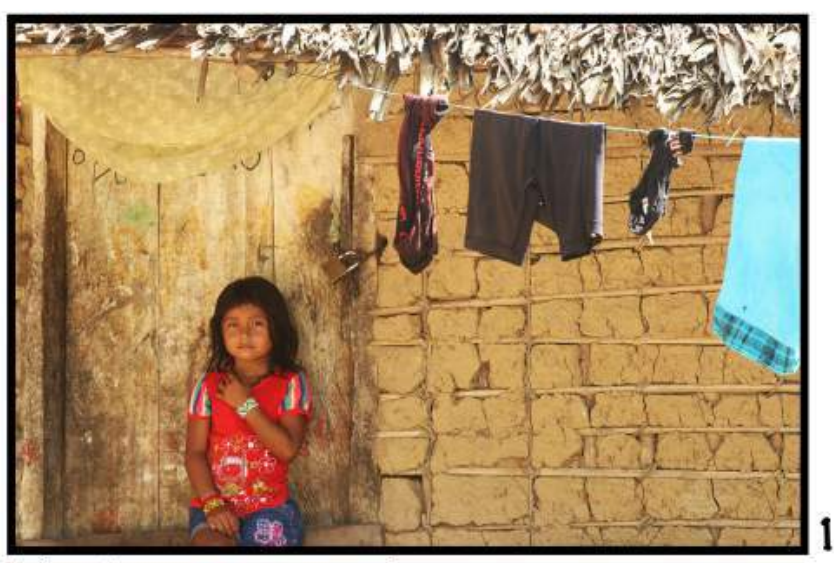

Mure 'e em sua casa atual.

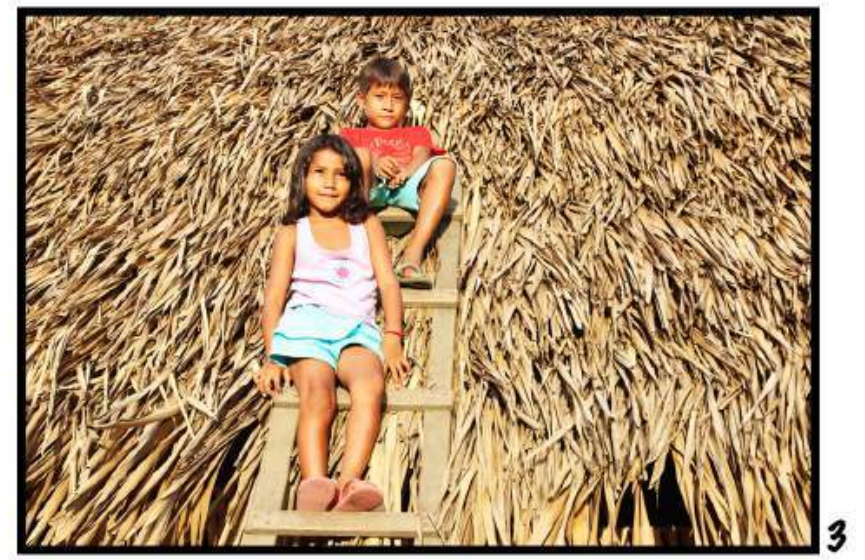

Japu e Atoaré brincam no telhado da casa de Takamuin .

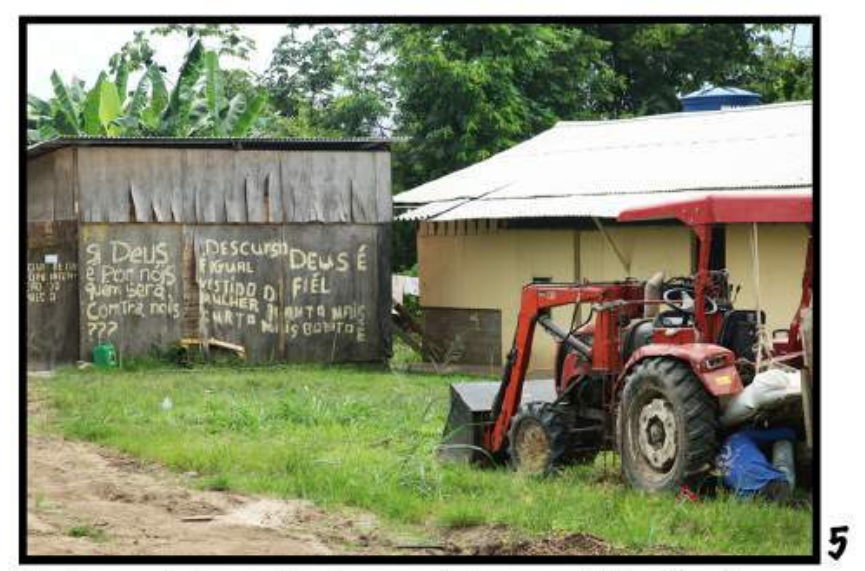

Trator e alojamento dos operários na aldeia Koatinemo.

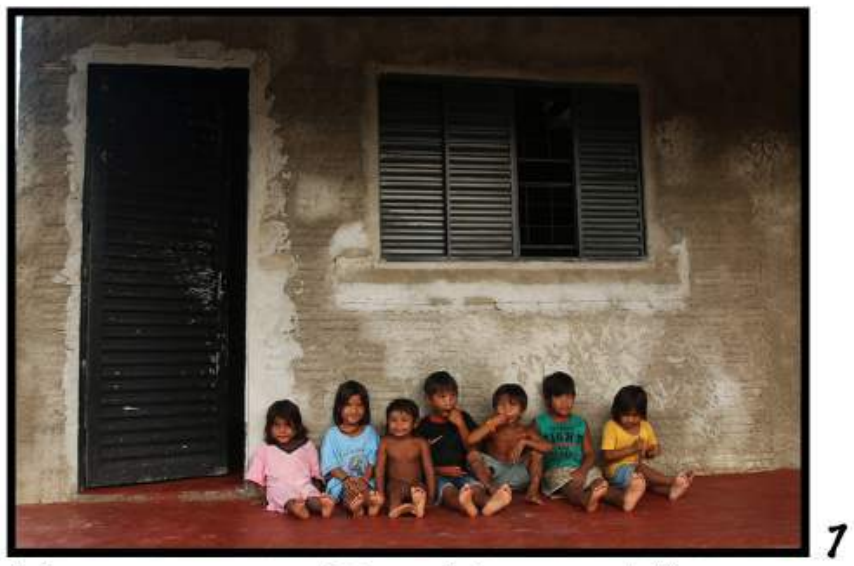

Criancas posam para foto na futura casa de Kuayvu.

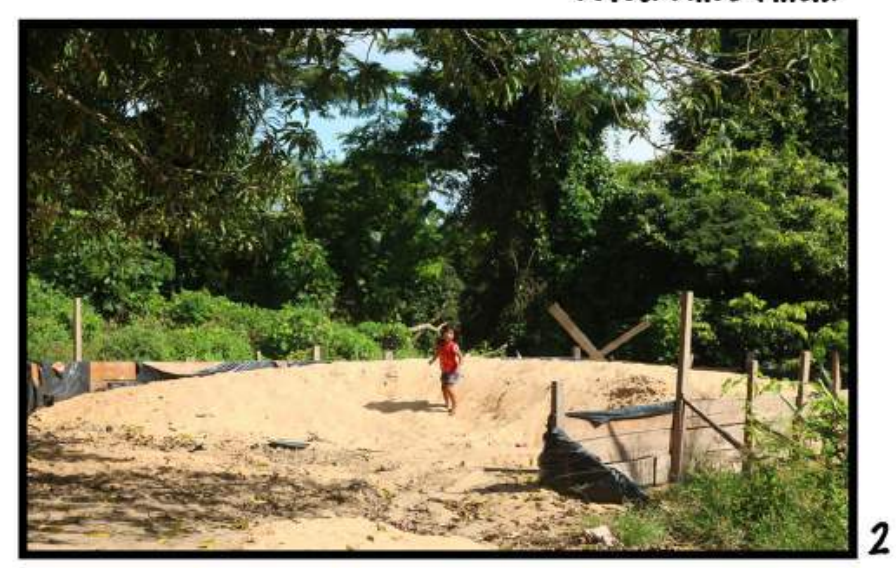

Mure é no local onde será construída sua nova casa.

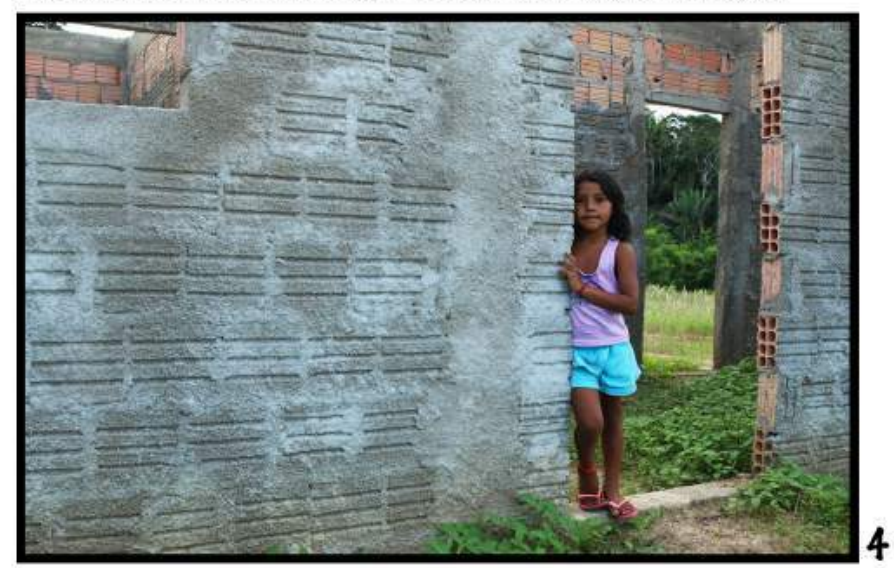

Japu em sua nova casa, ainda em construsão.

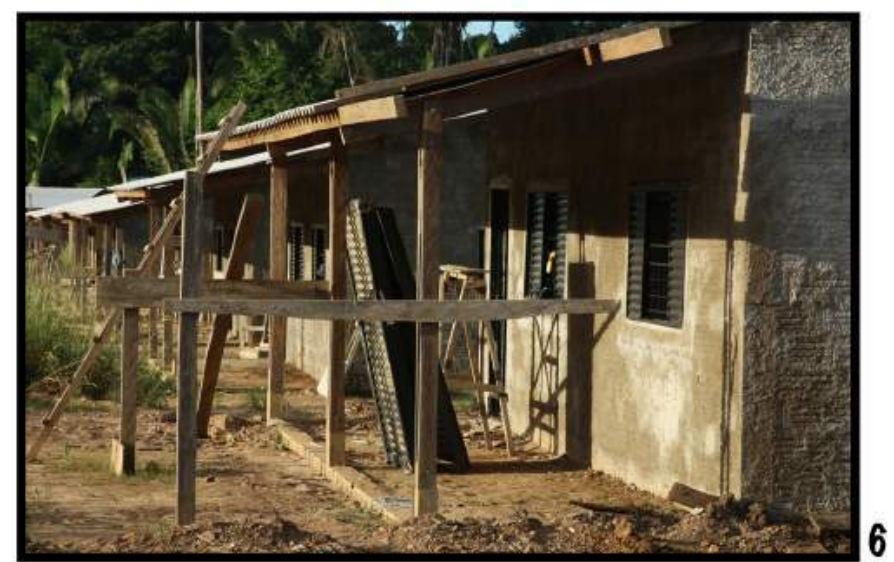

Vista das novas casas na aldeia Ita 'aka.

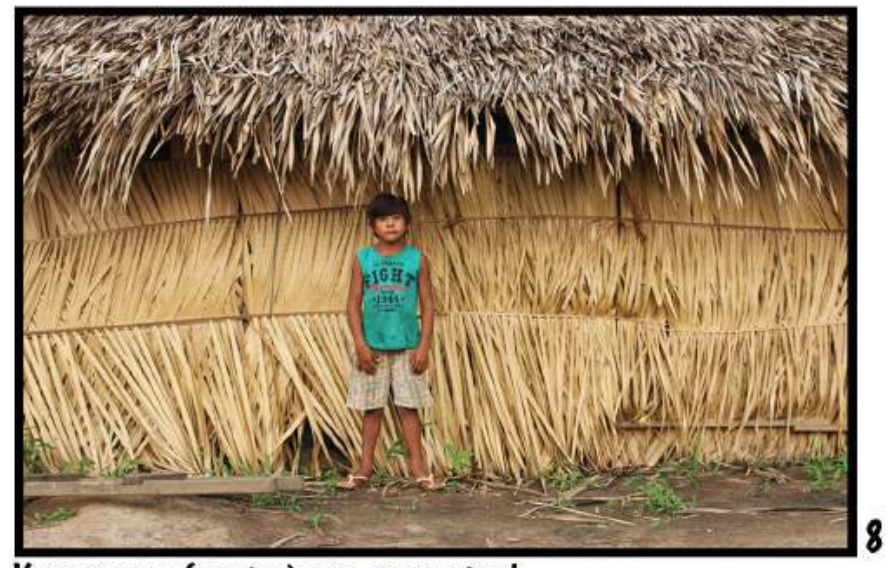

Kuayvu em frente à sua casa atual. 

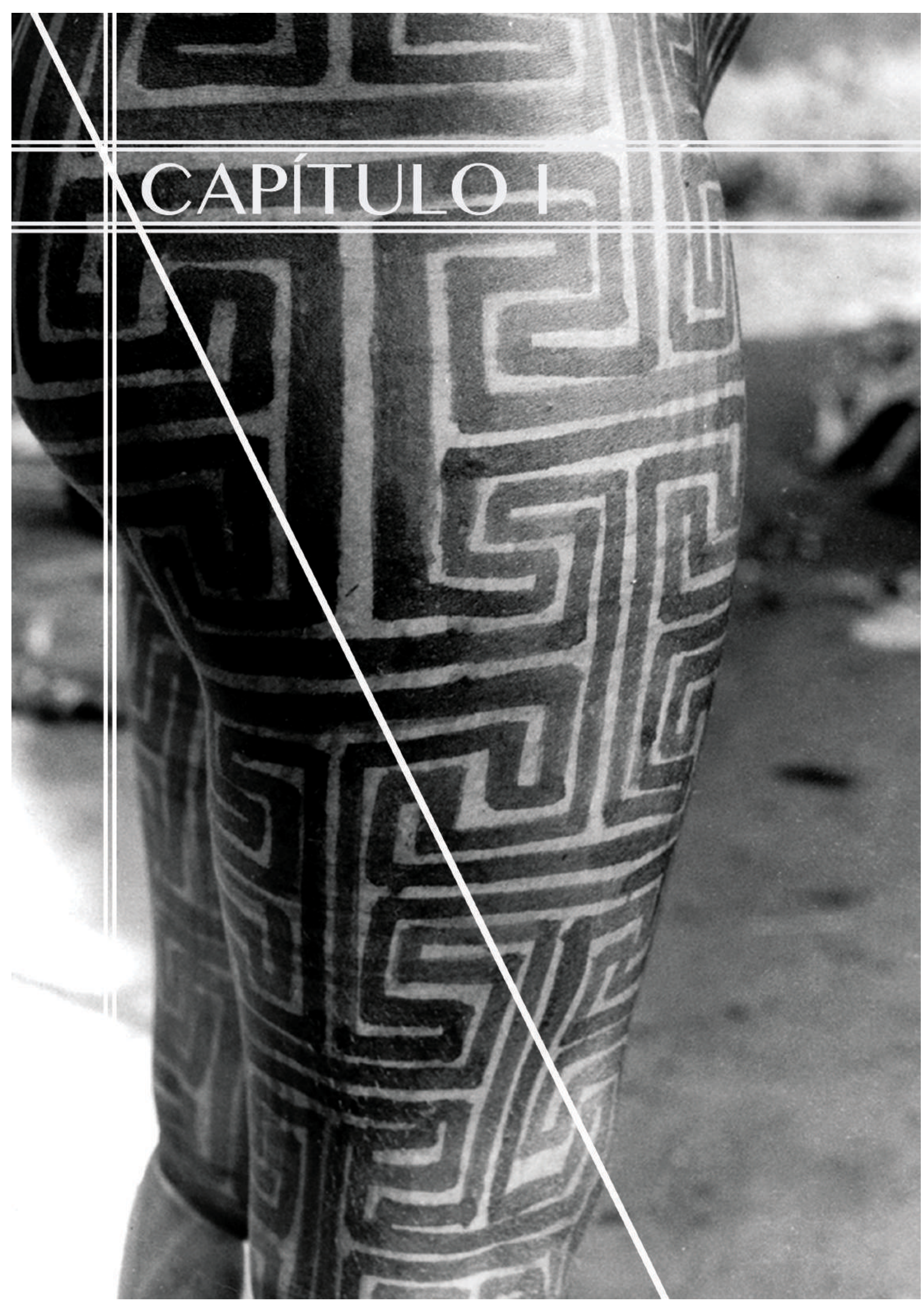


\section{CAPÍTULO 1}

\section{NOÇÕES DE IMAGEM E POSSIBILIDADES TRADUTIVAS}

\subsection{Problemas colocados pela imagem}

Uma das questões, se não a mais importante, a partir da qual surgiu esta investigação, é a de saber, afinal, o que seria imagem do ponto de vista nativo. Sem perceber a armadilha que havia criado, fui a campo com a proposta de entender e captar possíveis traduções para o termo. De partida, ficou claro que para a palavra imagem, com esta abrangência, não havia um correspondente asuriní e que a minha tarefa consistia em conhecer os conceitos nativos que são empregados para designar cópia, desenho, figura, reflexo na água, duplo, dentre outros.

Já no primeiro trabalho de campo, e informada pela etnografia de Müller (1992, 1993, 2000), apareceram três termos chave: ayngava, que designa imitação, réplica, medida e figura, palavra sempre precedida de um possuidor, ikwasiat, utilizado em referência aos padrões gráficos, e ynga, que se refere aos duplos (traduzido também por "alma"), ao princípio vital dentro do corpo e à sombra. Alguns destes termos eram usados pelos Asuriní em menção às imagens produzidas pelas tecnologias dos brancos; por exemplo, fotografias eram ayngava de alguém, uma fotografia de Myrá era Myrarayngava, fotografias de parentes (jeretá) eram jeretarayngava, e assim por diante. 
Mais tarde voltaremos aos termos asuriní para o domínio da imagem, incluindo, aí, as formas pelas quais se reportam às novas imagens ${ }^{17}$ advindas com o contato. Por ora, nos interessa explicitar o movimento que percorreu a investigação situada no confronto entre regimes de imagem diferentes. 0 desafio colocado, desde o princípio, foi o de acessar o que pudesse ser o domínio nativo da imagem por meio da relação dos Asuriní com imagens técnicas (fotografias, vídeos, filmes) ao longo do tempo.

0 uso indiscriminado do termo imagem, no início da pesquisa, teve como efeito perigoso transformá-lo em categoria de entendimento comum, como se pudéssemos chegar a possíveis traduções asuriní para imagem, para então percorrer o caminho inverso, traduzi-las para o português e confrontá-las com nossas próprias definições. Eu observava que este procedimento de empregar um termo para fazer a passagem entre culturas e línguas diferentes estava se tornando complicado e obscuro, não era das mesmas imagens que Asuriní e eu estávamos falando. Então, o objetivo de entender o que é imagem, do ponto de vista asuriní, converteu-se em uma questão metodológica (pelo menos inicialmente, até que o foco da pesquisa fosse ajustado), qual seja, a de problematizar o uso do termo como categoria de entendimento comum.

Este quadro foi agravado na medida em que me coloquei a seguinte questão: como antropóloga, de que imagem estava falando? Qual conceito e que ideias relativas a imagem levei ao campo na expectativa de obter uma tradução asuriní?

É, de certa forma, senso comum que a imagem representa ou substitui algo ausente ao reproduzir certos aspectos da aparência visível da pessoa ou do objeto. Wolff propõe tomar a ideia de representação ao 'pé da letra' e afirma que a imagem representa no sentido bem simples de que ela torna presente qualquer coisa ausente, ela representa o que ela não é. 0 autor chama atenção para a

17 Emprego "novas imagens" para designar as imagens técnicas (fotografia, audiovisual) produzidas pelos brancos em contraposição às imagens e objetos produzidos tradicionalmente pelos Asuriní, mesmo sabendo que a expressão pode apresentar problemas, tanto por desconsiderar as diferentes formas do desenvolvimento técnico da imagem (fotografia analógica, digital, cinema, televisão e vídeo), além do fato de que atualmente essas imagens não são tão novas assim, lá se vão quarenta anos de contato com a fotografia e com audiovisual. Quando for o caso, especificarei o tipo de imagem a que me reporto e o momento histórico exato em que ela aparece. 
relação entre a imagem e aquilo da qual é uma imagem; imagens nos remetem à coisa ausente e nos possibilita vê-la, pensá-la, ou evocá-la. Assim, "[u]ma imagem não é então, uma coisa, é uma relação com uma outra coisa. Toda imagem é uma imagem de alguma coisa" (Wolff, 2005, p. 21).

Para representar, a imagem não pode ter todos os traços do seu modelo, sob o perigo de se confundir com ele. Wolff evoca o diálogo "Crátilo" de Platão em que ele já alerta para o risco que podem representar as imagens:

Se alguma divindade, não contente de imitar tua cor e tua forma, como os pintores, reproduzisse também todo o interior de tua pessoa, tal como ele é, lhe desse a mesma nobreza e o mesmo calor, e lhe desse movimento, arte e pensamento, tais como existem em ti, em uma palavra, colocasse a teu lado um duplo de todas as tuas qualidades, haveria, neste caso, um Crátilo e uma imagem de Crátilo, ou dois Crátilos? (Platão apud Wolff, 2005, p. 21) ${ }^{18}$.

Reproduzir todos ou quase todos os traços do representado não seria, para Wolff, a característica da imagem. Em consonância com Platão, a ideia aqui é a de que a imagem tem uma inferioridade ontológica decisiva em relação ao representado, ela não é o verdadeiro ser, apenas sua imitação. Embora efetivamente real, não possui a realidade daquilo que representa: "[...] ela é material, a coisa representada é carnal; ela é inerte, a coisa representada é viva, etc." (Wolff, 2005, p. 23) ${ }^{19}$.

Voltando a Platão, uma das primeiras, senão a primeira reflexão acerca das imagens aparece no texto da República, em que o filósofo discorre sobre três formas de camas. Platão estabelecia uma separação entre níveis de representação, criando uma hierarquia entre a coisa em si (a cama) e as formas como esta coisa poderia ser apreendida pela percepção humana. Há, assim, uma

18 Extraído de Platão, Diálogos, "Crátilo", trad. Carlos Alberto Nunes, vol. IX da Coleção Amazônica (Belém: Universidade Federal do Pará, 1973), 432bc, p. 182-183.

19 Wolff em seu texto "Por trás do espetáculo: o poder das imagens" vai muito além desta noção de imagem que apresento. Ele vai trabalhar com a ideia de que o poder das imagens provém de seus defeitos (em relação à linguagem), especialmente o de apontar para o fato de que ela só conhece o indicativo e o tempo presente. 0 autor volta aos ídolos da Grécia Antiga e medievais e percorre a história até os dias atuais para refletir sobre o poder das imagens: "[...] sua incapacidade de distinguir o tempo, é o que faz sua força mágica, religiosa" (Wolff, 2005, p. 28). 
imagem propriamente dita (eikon) e o simulacro (eidolon). Como afirma Gonçalves (2010), a ideia de imagem propriamente dita já surge deficiente pois o que a funda é uma ausência: na impossibilidade de representar o real ela não compete com o original. 0 simulacro, sim, competiria com o modelo apontando para a ideia de mimesis, de imitação, uma forma perigosa de imagem para Platão, pois tomaria o lugar do real (modelo), confundindo entre verdadeiro e falso.

É Vernant (1990[1973]) quem nos ajuda a entender historicamente as diferentes noções de imagem no Ocidente. Na Grécia Antiga, teríamos os ídolos arcaicos, objetos utilizados em contextos religiosos que operavam a figuração de mortos e deuses. 0 ídolo seria um símbolo por intermédio do qual uma força do além, isto é, um ser fundamentalmente invisível, se presentificava no mundo. Tais figuras, como é o caso do kolossói e do xoánon analisados pelo autor, pretendem estabelecer com a força sagrada "uma verdadeira comunicação", "um contato autêntico" ao torná-la presente. No entanto, na confluência dos séculos $\mathrm{V}$ e IV a teoria da mimesis, da imitação, esboçada por Xenofonte e sistematizada por Platão, marca, na cultura grega, o momento em que se concluiu a versão que conduz da "presentificação do invisível para a imitação da aparência" (Op. cit., p. 318-319) em que:

O símbolo através do qual uma força do além, isto é, um ser fundamentalmente invisível, é atualizada, presentificada neste mundo, transformou-se em uma imagem, produto de uma imitação versada que, pelo seu caráter de técnica erudita e de processo ilusionista, introduz-se desde então na categoria geral do "fictício" - que nós chamamos de arte. A partir daí, a imagem depende do ilusionismo figurativo, tanto mais que não se aparenta ao domínio das realidades religiosas (Vernant, 1990[1973], p. 319).

Contudo, embora segundo Vernant a imagem tenha deixado de encarnar o invisível, o além e o divino, constituindo-se como imitação da aparência, esta separação não parece ter sido tão clara e efetiva pois as imagens, especialmente as técnicas, talvez pela completa identidade com aquilo que representam, continuam a provocar confusão e ambivalência. Olhamos para a televisão e acreditamos ver a própria realidade, sem representação; o trabalho da produção da imagem não é mais visto na imagem, sendo a imagem o real (registrado); essa é a ilusão, segundo Wolff (2005, p. 44), que consiste em fazer crer que a realidade 
tem o poder de sua própria representação. Gonçalves (2010) afirma que a origem do que representa a imagem para a cultura ocidental não estaria no eikon (imagem propriamente dita), mas no eidolon (simulacro), pois a essência da imagem nos dias de hoje estaria relacionada àquilo que produz ambiguidade na percepção, o que coloca em relação concepções de originalidade e cópia, o que revela e o que engana ${ }^{20}$.

Imagem, entre nós, pode ser muitas coisas: um quadro, uma fotografia, um filme, mas também uma imagem mental, uma lembrança, um sonho. Esta constatação, de certa forma intuitiva, encontrou eco em alguns estudiosos do tema. Hans Belting, no início da obra Pour une anthropologie des images, afirma: "[...] o discurso sobre as imagens se tornou um sujeito da moda [...] o termo 'imagem', que não cessa de emergir por todos os lugares, age como um narcótico que dissimula esta evidência de que não é sempre das mesmas imagens que nós falamos (Belting, 2004 [2001], p. 17, tradução minha).

Mitchell, em seu livro Iconology - image, texte, ideology, apresenta formulações interessantes sobre o fenômeno chamado "imagem" (imagery). A primeira consideração trata da variedade de coisas que correspondem a este termo.

Nós falamos de pinturas, estátuas, ilusões óticas, mapas, diagramas, sonhos, alucinações, espetáculos, projeções, poemas, padrões, memórias, e ainda ideias como imagens, e a absoluta diversidade desta lista de coisas torna qualquer entendimento sistemático e unificado impossível (Mitchell, 1986, p. 9, tradução minha).

0 argumento do autor se afasta da pretensão de definir imagem por sua natureza, e de uma maneira universal, para dar lugar à compreensão de quais são os tipos de imagens existentes. Assim, segundo Mitchell (Op. cit., p. 10), as imagens podem ser: gráficas (como as pinturas, as estátuas e os desenhos);

\footnotetext{
20 Debray (1992) vai dizer que vivemos um "arcaismo pós-moderno" em que há convergências entre as imagens produzidas atualmente e os ídolos arcaicos; no entanto, embora a espiral das imagens nos faça repassar pelos mesmos pontos, não estamos no mesmo nível ontológico. Diz o autor que a imaterialidade do vídeo reativa aspectos do "colosso" arcaico: uma imagem sem autor e autorreferente se coloca, automaticamente, em posição de ídolo, e nós de idólatras, tentados a adorá-la diretamente. Ver Debray, 1992, p. 411-421.
} 
óticas (como os reflexos no espelho e as projeções); perceptivas (como as aparências); mentais (como os sonhos, as memórias e as ideias); e verbais (como as metáforas e as descrições) ${ }^{21}$. Para o autor, as imagens se diferenciam umas das outras muito mais em função do contexto institucional e das disciplinas intelectuais das quais participam do que por sua natureza. Imagens mentais pertenceriam ao domínio da psicologia ou epistemologia; imagens óticas, à física; imagens gráficas, esculturais e arquiteturais, à história da arte; imagens verbais, à crítica literária; imagens perceptivas ocupariam uma região de fronteira onde filósofos, neurologistas, psicólogos e historiadores da arte, além de estudantes de ótica, colaboram ${ }^{22}$.

Se, mesmo entre nós, não falamos da mesma coisa quando o tema é imagem, o que se passa quando projetamos esta categoria no universo ameríndio?

A questão da tradutibilidade dos termos era mais complexa do que parecia. Eu começava a perceber que, por mais que os Asuriní utilizassem as palavras: imagem, desenho, fotografia e vídeo - o que eles faziam para traduzir seus próprios conceitos para o português -, não estavam se referindo às mesmas coisas que eu. Fotografias podem ter intencionalidade e agir, câmeras de vídeo captam o ynga das pessoas e mostram suas sombras ao reproduzir sua imagem. Tratava-se de referentes muito diferentes, aludidos por meio das mesmas palavras.

Referentes diferentes ou mundos diferentes remontam à recente discussão das ontologias que, embora não constitua o horizonte teórico desta

\footnotetext{
${ }^{21}$ Ainda que Mitchell se afaste da pretensão de definir imagem em sua natureza e de forma genérica, ao propor tomar o campo da imagem como uma vasta família que migrou ao longo do tempo e do espaço (e que sofreu profundas mudanças neste processo), fala de uma matriz de onde os demais tipos de imagem teriam derivado. Enquanto conceito-base, o termo imagem aparece associado à ideia de semelhança, similitude e parecença (likeness, similitude e resemblance). Ver Mitchell, 1986, p. 9-10.

22 Apesar de não citar a antropologia como área do conhecimento, eu arriscaria dizer que enquanto disciplina ela pode trabalhar com diferentes tipos de imagens, principalmente as gráficas, mentais e verbais. 0 autor também não cita as imagens técnicas como a fotografia e o audiovisual, com as quais a antropologia visual trabalha. Seriam imagens gráficas? E no caso de projeções de vídeo ou web, seriam imagens óticas? Pensar as imagens técnicas à luz do esquema de Mitchell pode colocar questões interessantes ao próprio modelo do autor; obviamente esta tarefa não está no escopo deste trabalho.
} 
pesquisa, nos auxilia a compreender o estatuto da imagem ameríndia. Se no regime perspectivista (Viveiros de Castro, 2002) ou animista (Descola, 2005) ocorre a generalização de interioridades humanas aos não humanos, combinada com a descontinuidade de corpos, e então, de perspectivas de mundo, é possível que imagens e objetos, por exemplo fotografias, evoquem relações muito diferentes com os seres viventes.

Na Amazônia, o problema da imagem é geralmente um problema de objeto porque, na ontologia animista ou perspectivista (Cf. Descola, 2005 e Viveiros de Castro, 2002), lá onde encontramos a separação de intencionalidades ou "almas" e formas físicas ou vestimentas corporais, as maneiras de transformação ou corporificação de seres podem esconder imagens que chamamos "objetos". As imagens como objetos podem ter uma intencionalidade humana, da mesma maneira que os outros seres e imagens mentais (ou do sonho) podem ser o protótipo de objetos. 0 trabalho desta tese, em parte, é mostrar que entre as diferentes relações estabelecidas entre índios e fotografias, há uma ênfase grande quanto à intencionalidade dessas novas imagens que passam a circular cada vez mais intensamente.

Poderíamos dizer que é possível pensar objetos exteriores ao mundo asuriní (a fotografia, por exemplo) como envolvidos nas "redes personificadas de relação" - para utilizar um termo empregado por Cesarino (2012) em um artigo no qual o autor propõe analisar a escrita e os desenhos aplicados aos corpos marubo como transformações de conhecimentos xamânicos. Cesarino fala de um processo no qual os "livros", enquanto objetos utilizados nas escolas indígenas, se integram nas relações personificadas e explica: "0 pensamento personificante pode se estender potencialmente a tudo, assim prevendo agentes (e, quiçá, agentes dentro de agentes) lá onde encontramos apenas objetos" (Op. cit., p. 123).

Viveiros de Castro (2004) aponta para o fato de que o perspectivismo ameríndio coloca o problema da tradução de mundos, que poderia ser resumido na ideia de que, neste regime, não se trata da descoberta de um referente comum para duas diferentes representações (multiculturalismo, uma natureza e várias representações), mas de tornar explícito que uma mesma representação se aplica 
a dois referentes distintos, a depender da perspectiva. Em sua formulação a respeito do que seja a "equivocação" (ou o método da equivocação controlada), o autor chama atenção, não para falhas no entendimento - entre índios e antropólogos, por exemplo, como procurei mostrar ao falar dos malentendidos em torno da tradução do termo imagem -, mas para a compreensão de que os entendimentos envolvidos em uma situação como esta são necessariamente diferentes, pois dizem respeito a diferenças nos próprios mundos que estão sendo vistos. De acordo com este método, talvez, a questão mais pertinente seria a de saber, afinal, o que é uma fotografia para os Asuriní? Ou, o que está sendo expresso ao empregarem o termo fotografia?

O estatuto vivo da imagem não é exclusividade dos Asuriní, entre diversos povos ameríndios das terras baixas sul-americanas parecem operar concepções de imagem que a relacionam a um mundo outro, e que associam a extensão da qualidade ou essência do ser representado para aquilo que representam ${ }^{23}$. Tais concepções estabelecem uma relação intrínseca entre a noção de imagem e o princípio vital, e estão fundamentadas no xamanismo ${ }^{24}$ como ponto de vista privilegiado dessas sociedades e da figura do xamã como organizador e catalisador dessa visão. Para Lagrou (2007), essa concepção de imagem, relacionada ao princípio vital, não cria a oposição entre verdadeiro e falso, ou verdadeiro e ilusório. Como uma representação que partilha de forma metonímica a qualidade (ou "essência") do representado, a imagem da pessoa estabelece uma relação metonímica com a pessoa pois é constitutiva do ser.

Como se verá mais detidamente no capítulo 2 desta tese, entre os Asuriní, há relação entre a imagem (ayngava) e o princípio vital compartilhado entre humanos e espíritos (ynga). Relações entre ayngava e ynga estão na base da

230 estatuto vivo da imagem e sua relação com o princípio vital podem ser observados em diversos grupos indígenas, como por exemplo entre os Wajãpi (Gallois, 1988), entre os Kaxinawá (Lagrou, 2007), entre os Wauja (Barcelos Neto, 2008), dentre outros.

${ }^{24}$ Segundo Carneiro da Cunha $(1998$, p. 12), o xamanismo opera no sentido de "interpretar o inusitado, conferir ao inédito um lugar inteligível, uma inserção na ordem das coisas" e apenas o xamã "[...] por definição, pode ver de diferentes modos, colocar-se em perspectiva, assumir o olhar de outrem [...] E é por isso que, por vocação, desses mundos disjuntos e alternativos, incomensuráveis de algum modo, ele é o geógrafo, o decifrador, o tradutor" (Op. cit., p. 17). Destaca-se que a definição apresentada pela autora se refere à teoria do perspectivismo ameríndio. In: Viveiros de Castro, 2002. 
ideia de que imagens, incluindo aí as fotográficas e videográficas, podem ter agência.

\subsection{Trilogia ynga, ikwasiat e ayngava}

Sobre o ynga

Em seus estudos acerca da arte gráfica e do xamanismo asuriní, Müller (1992, 1993, 1996) traduziu o ynga por princípio vital compartilhado entre seres viventes e manipulado pelos xamãs nos rituais xamanísticos. Ynga seriam, também, as manifestações deste princípio vital animado no corpo como a voz, a pulsação, as batidas do coração, além da sombra de alguém projetada no chão (1993, p. 170). Nos rituais xamanísticos, os espíritos xamãs primordiais ${ }^{25}$ (Tivá, Apykwara e Karovara) são chamados para dançar e tomar mingau junto aos xamãs transmitindo-lhes ynga que são aplicados aos pacientes que estavam ameaçados de perdê-lo. No corpo do doente o ynga é introduzido e "guardado dentro" por intermédio de sopros, massagens, fumaça de tabaco e mingau ingerido"26.

No entanto, o ynga não estaria apenas associado ao tratamento de doentes, mas também à caça, à agricultura bem como à preservação da vida do guerreiro. Ao afirmar que os espíritos Tajaho (porco-do-mato) e Arapoá (veado), ligados à caça e à agricultura, respectivamente, também transmitem ynga, Müller conclui que a noção de ynga trata do "[...] princípio vital existente, não só no corpo das pessoas e elemento constitutivo de seres viventes, humanos e espíritos, mas extensivo aos resultados das ações que estes seres executam sobre a natureza" (1993, p. 171). No caso do guerreiro que recebe ynga, ele não padece por conta da diminuição do princípio vital, como acontece com os doentes, mas ao contrário, sofre pelo seu excesso: "[...] segundo os Asuriní, ele é tatuado para

\footnotetext{
${ }^{25}$ Segundo Müller (1993, p. 189-190), os espíritos xamãs primordiais são espécies sobrenaturais que parecem reproduzir a sociedade humana em outros mundos e que, no passado mítico, desempenhavam funções de xamãs, associados à cura de doenças.

${ }^{26}$ No caso dos rituais xamanísticos para cura de doentes os espíritos Apykwara, Karovara e Tivá dão também o moynga, espécie de ynga suplementar que os Asuriní traduzem por remédio.
} 
se tirar de seu corpo o sangue de sua vítima, que 'fica na barriga, dói e pode lhe fazer mal'" (Op. cit., p. 170). 0 guerreiro tatuado nos rituais do Turé27 passa pelo processo de sangramento, como se pudesse ser retirado de seu corpo uma substância, que Müller se pergunta se seria o ynga da vítima.

Na década de 1990, quando realiza pesquisa acerca das performances rituais e da transmissão dos conhecimentos por meio do uso do vídeo, Müller obtém outras traduções para o termo ynga. 0 índio Manduka se refere à imagem em movimento na televisão como a "sombra" do corpo humano (princípio vital visualizado mas sem matéria). Müller se interessa, particularmente, por esta opção tradutiva e diz: "A escolha da palavra 'sombra' por Manduka faz referência ao movimento, comparando em seu depoimento com um gesto, sua própria sombra que se mexia, à imagem em movimento na televisão" (2000, p. 186). No vídeo Morayngava ${ }^{28}$, resultante desta pesquisa, a palavra ynga, portanto, aquilo que anima e que movimenta a substância vital dos seres viventes, foi traduzida por "alma", que remete, segundo Müller, a estas ideias na língua portuguesa (Op. cit., Ibid.).

Até aqui, ynga aparece como princípio e substância vital que anima o corpo e que se manifesta por meio da voz, pulsação e coração, além de "sombra" e "alma". Durante minhas incursões ao campo, interessada nos termos asuriní para as novas imagens e sons, obtive outras traduções para o complexo conceito de ynga. As conversas com o jovem xamã Parajuá foram as ocasiões mais elucidativas neste sentido. Ele afirmou que "[...] o ynga é dois: é sombra e para o pajé é outra coisa". Sombra em relação à imagem que se movimenta na televisão ou à projeção do corpo no chão com a incidência do sol, como ele me mostrava gesticulando numa das situações, e que pode ser considerada como índice da presença do princípio vital animado no corpo. Parajuá continua ao explicar que, para o pajé, ynga também pode se referir a coisas diferentes: "[...] você dorme e

\footnotetext{
${ }^{27} \mathrm{O}$ Turé é um complexo ritual que atualiza a cosmologia e as narrativas míticas, articulando diversas instituições sociais como a guerra, a iniciação dos jovens e a celebração dos mortos, além de ser o nome das flautas tocadas no ritual. Ver Müller (1993).

28 Direção: Regina Müller e Virgínia Valadão. São Paulo: CTI/ Vídeo nas aldeias (Asuriní do Xingu), 1997, 16 min, NTSC, cor.
} 
sonha, esse aí que vai é ynga, ou então na festa de Tivá, Apykwara e Karovara, de manhã, pega ynga para imunara [posição do paciente nos rituais terapêuticos], pega do espírito e passa para imunara". Nos rituais xamanísticos, o pajé pega o ynga dos espíritos, põe diretamente no paciente, através de gestos e massagens, ou o aplica no mingau e na farinha que serão consumidos pelos imunara. Manipulado nos rituais, "o ynga parece uma teia de aranha branca e só pajé vê [pajé uesak]", disse o jovem xamã.

Parajuá trazia uma importante contribuição ao chamar atenção para o fato de que a perspectiva do xamã em relação ao que seja o ynga difere da dos homens comuns. E, para além disso, apontava para uma acepção do termo que eu não conhecia até então, indo além do princípio vital manipulado nos rituais, ao se referir à sua circulação fora do corpo do xamã em momentos de sonho ou viagens ao mundo dos espíritos. Nestes casos, diz Parajuá, "[...] é jeynga [meu ynga], que vai". O ynga aqui, como ele mesmo me apontou, não é uma parte incompleta do xamã, mas é o próprio pajé, uma espécie de imagem corporal animada que se desloca aos mundos dos espíritos e se integra à vida "social" existente nesses mundos, recebendo nomes próprios, casando e tendo filhos.

0 acesso às moradas dos espíritos se dá através de caminhos percorridos apenas pelos xamãs, no momento do sonho ou durante os rituais xamanísticos na ocasião em que perdem os sentidos e "morrem um pouquinho", como me explicaram alguns Asuriní29 ${ }^{2}$ Müller afirma que os xamãs visitariam, também, a aldeia dos avaeté (avá = gente, eté = de verdade), onde vive Maíra e para onde vão os Asuriní após a morte. Não possuo informações a respeito da "aldeia dos avaeté", o que ouvi frequentemente é que, quando alguém morre, seu ynga vai para o caminho de Maíra (mairipé), deixando imprecisa a informação se haveria ou não uma aldeia dos mortos nessas proximidades (esse tema será retomado no capítulo 2). 0 interessante aqui é que, como no caso do sonho do xamã, dizem que "a pessoa vai encontrar Maíra", embora seja o seu ynga que viaje, o que nos permite apreender que o ynga é a própria pessoa e não apenas um princípio

29 Os Asuriní interpretam o "transe extático" como morte. Müller (1993, p. 184) declara nunca ter obtido informações a respeito do momento preciso em que os Asuriní viajam aos mundos dos espíritos nem, tampouco, a respeito das relações entre o transe extático (morte dos xamãs durante os rituais) e as viagens a outras esferas cósmicas. 
animado ou a "alma" dissociada do corpo. Outro aspecto importante é que, nos dois casos, ao se referirem ao ynga que aparece dissociado do corpo, o termo vinha precedido de um possuidor; Parajuá me fala em primeira pessoa "jeynga" ou gaynga ( $g a=$ ele) para se referir ao ynga de um pajé no momento de suas viagens cósmicas. No caso da pessoa que morreu, também se referem ao ynga dele ou dela, neste caso evitando dizer o nome.

Como se vê, o ynga se refere a uma gama abrangente de fenômenos diferentes, dificilmente traduzíveis por um único termo. Essa complexidade não é, nem de longe, uma novidade. Diversos etnólogos já apontaram para os desafios envolvidos neste empreendimento ao problematizar o uso freqüente de termos pela antropologia que, na tentativa de elucidar conceitos ameríndios, acabam por ficar a meio caminho do entendimento. Como bem observa Garcia, que estudou os Awá-Guajá, é comum na literatura de nossa disciplina traduzirmos conceitos ameríndios referentes às diversas formas em que é concebido o destino da pessoa post mortem por meio de ideias como "alma", "sombra", "espírito", "espectro", "princípio vital", dentre tantos outros (Garcia, 2010, p. 96). Viveiros de Castro (1986, p. 495) também se mostra reticente na utilização de termos como "alma", "sombra" e "princípio vital", como tradutores de ideias a respeito da separação da pessoa Araweté, uma vez que tal população apresenta uma multiplicidade de enunciações a respeito da morte, sendo difícil reduzi-los a uma única ideia. No entanto, embora a crítica aos termos exista, muitas vezes não é possível escapar completamente a eles, como se vê no trecho citado a seguir. 0 ynga se comportaria de modo semelhante ao ĩ araweté:

\footnotetext{
0 termo ĩ, além de "sombra", "imagem", "reprodução" (a gravação de uma voz é a Ĩ da fala ( $\tilde{\mathrm{n}} \mathrm{e}^{i \sim e}$ ); ĩ não é só a imagem visual) designa também a pulsação sanguínea, os batimentos vitais do corpo. Nessa acepção, eu o traduziria por "princípio vital-animado", uma vez que os movimentos pulsáteis do corpo vivo são ao mesmo tempo a presença e o índice da presença da $\tilde{\imath}$. [...] No contexto da escatologia, ele é designado como [...] "aquilo que irá (para o céu)", ou [...] "futuro companheiro dos deuses", e finalmente por duas expressões decisivas: Maï di, "futuro Maï", e bïde rĩ, "futura gente-Pessoa" (Viveiros de Castro, 1986, p. 514).
}

Garcia fala em "vitalidade" e em "princípio vital animado" para a tradução 
de uma noção correlata ao ynga asuriní, o haitekéra entre os Awá-Guajá, e aponta para uma diferenciação de termos para se referirem ao princípio vital integrado ao corpo e ao mesmo princípio circulando fora dele:

Embora eu defenda que - ao menos lingüisticamente - uma tradução para haitekéra seja irrealizável (ou improdutiva), proponho que para a compreensão dessa ideia de "vitalidade" devemos pensá-la a partir de dois níveis: um interior ao corpo, expressado pela ideia de -ite; e um exterior, que seria o próprio haitekéra. -Ite seria literalmente o princípio vital realizado no "corpo" (-piréra), que resulta a própria condição de ser humano vivo (haitekéra pãi), para que haja vida é necessário que exista, além do corpo, a vitalidade (-ite), aquilo que faz um ser vivo, o que promove a vitalidade do corpo. 0 haitekéra seria esse mesmo -ite, porém, em circulação (Garcia, 2010, p. 100).

Entre os Asuriní, até onde pude observar, o princípio vital dentro do corpo e fora dele é designado pelo mesmo termo ${ }^{30}$, o que os aproximaria mais do modo como este princípio foi descrito entre os Araweté. Neste povo, o termo $\tilde{l}$ designaria tanto o princípio vital quanto a imagem-sombra, correspondendo a uma imagem-corporal (um hiro) quando se encontra separado do corpo nos momentos do sonho, na morte e nas perdas da alma por captura espiritual. Segundo, Viveiros de Castro, a distinção a ser feita é entre uma ĩ ativa, a 'imagem vital', e uma ĩ passiva, a 'imagem-sombra'. "A primeira é da ordem das causas, é interior (o corpo é o envelope dessa Ĩ), possui uma existência autônoma e nãocondicionada; a segunda, a ĩ geradora do ta'o we (espectro) terrestre, é da ordem dos efeitos, é exterior, marca bruta de uma ausência, e sua 'autonomia' é antes automatismo" (Viveiros de Castro, 1986, p. 515). Não saberia dizer se o ynga enquanto sombra é o gerador do espectro anhynga liberado após a morte, mas creio que essa possibilidade possa ser considerada pois os Asuriní também se

\footnotetext{
30 Não parece haver um termo para a tradução da palavra "corpo"; alguns me disseram ser jeraryva, que quer dizer, também, "meu dono", "meu chefe", "meu pai de verdade", "meu corpo tudinho". Oreraryva é "nosso chefe", nome empregado para se referirem às lideranças jovens que emergiram há pouco mais de dez anos. Ao falar do corpo, era recorrente que listassem o que compõe o corpo. Boaiva me disse que no seu corpo haveria: jepirera (minha pele), jeraju (minha carne), jekynga (meus ossos), jeynga (coração, e as batidas do coração, pulsação do corpo todo). Outros citaram também jejyavevui (meu pulmão). Mas não foi possível realizar o aprofundamento de tais informações.
} 
referem a estes espectros por ynguera (o que foi ynga), e, quando iam me descrever como eram os anhynga, começavam por fazer analogias à sombra.

Considero que a tradução de ynga por "alma" - nas situações em que este princípio é ejetado do corpo ou mesmo para se referir à sombra da televisão não seja a mais adequada. Pois, nestas situações, "ele é a pessoa", como me indicam os Asuriní, e não a "alma" em oposição ao "corpo". Separado do corpo, o ynga se comporta mais como um duplo, na acepção trabalhada por Vernant ao falar do substituto do morto na Grécia Antiga, o kolossós, do que como "alma". A ideia de duplo, que será incorporada ao campo dos estudos ameríndios por Carneiro da Cunha (1978), figura uma categoria que pressupõe uma organização mental diferente da nossa.

O duplo é uma coisa bem diferente da imagem. Não é um objeto "natural", mas não é também um produto mental: nem uma imitação de um objeto real, nem uma ilusão do espírito, nem uma criação do pensamento. 0 duplo é uma realidade exterior ao sujeito, mas que, em sua própria aparência, opõe-se pelo seu caráter insólito aos objetos familiares, ao cenário comum da vida. Move-se em dois planos ao mesmo tempo contrastados: no momento em que se mostra presente, revela-se como não pertencendo a este mundo, mas a um mundo inacessível (Vernant, 1990[1973], p. 309).

A tradução que fazem povos ameríndios de termos nativos para designar o princípio vital e o duplo (que alguns chamam de "alma") por imagem não acontece apenas entre os Asuriní. No caso yanomami algo semelhante se passa ${ }^{31}$. Como adverte Albert $^{32}$, embora os Yanomami também utilizem o termo utupë para designar todas as nossas manifestações iconográficas (imagens no papel ou digitais, animadas ou não), bem como as representações plásticas (desenhos, gravuras, pinturas, estátuas), modelos reduzidos (jogos e miniaturas), reflexo de uma pessoa na água ou num espelho, sombra ou eco (a "imagem do som") e as

\footnotetext{
31 Para outros aprofundamentos na relação xamã-espírito-imagem ver Viveiros de Castro, 2006.

32 Ver: "Images, traces et 'hyper images': impromptu d'ethnographie noctambule". 0 artigo encontra-se disponivel on line mas não foi possível precisar sua data de publicação. Disponível em: http://www.ctrlab.inf.br/reflexao.html. Acesso em setembro de 2015.
} 
gravações sonoras ("imagem de falas"), utupë designa, sobretudo, um componente ontológico fundamental de todo existente - a imagem do corpo e a essência vital associada ao sangue e à energia corporal.

Albert afirma que a noção de imagem yanomami não pode ser reduzida à representação figurativa (em um suporte material) de uma realidade préexistente e que, em matéria xamânica, a polaridade seria inversa. Ao invés de representar uma realidade original, a "(sobre) realidade original do ser"33 se encontra situada no lado da imagem (acessível somente aos xamãs), e a ilusão do lado do mundo físico (visível a todos) se constituindo como uma versão de segunda ordem. Assim, o interesse que os Yanomami apresentam em relação aos outros povos da Amazônia seria essa espécie de grau zero do suporte, da representação, uma espécie de radicalidade interna: como se o corpo do xamã fosse o único lugar onde essas imagens mentais se materializassem.

Tendo em vista que, no caso asuriní, a noção de ynga é extremente complexa e que exigiria um estudo à parte, não proponho grandes radicalidades tradutivas ao que já havia sugerido Müller. Gostaria de trabalhar com as acepções do termo em relação ao princípio vital (que anima o corpo e as suas manifestações tais como voz e pulsação, etc.) que é, também, manipulado pelos xamãs nos rituais xamanísticos, podendo adquirir a forma de substâncias ao ser colocado no mingau e na farinha, por exemplo; como duplo do pajé em suas viagens aos mundos dos espíritos e nos sonhos; e como sombra em referência à imagem da televisão. Ao longo desta tese utilizarei sobretudo o ynga em referência ao princípio vital que anima o corpo e às suas manifestações (principalmente a voz), além da ideia de sombra projetada no chão ou na TV, considerada como espécie de manifestação (ou projeção) do princípio vital que anima o corpo.

\footnotetext{
33 "(sur)réalité originelle de l'être". Ver: "Images, traces et 'hyper images': impromptu d'ethnographie noctambule".
} 
Ikwasiat, desenho

Os Asuriní são conhecidos pelo esmero e sofisticação na fabricação de cerâmicas decoradas com motivos geométricos, e pelo detalhamento e habilidade com que aplicam estes mesmo motivos gráficos aos seus corpos. Os desenhos geométricos são referidos pelo termo ikwasiat, que compreende as criações gráficas que se aplicam aos suportes corporais e artesanais - cerâmica, cestaria (peneiras, cestos, arcos e flechas), têxtil (redes de algodão e acessórios) e cuias. 0 modo de aplicação dos desenhos nos objetos, sejam rituais, utilitários ou decorativos, varia de acordo com a técnica, a matéria-prima e quem se dedica à produção (mulheres ou homens). Por exemplo, na pintura da cerâmica, utiliza-se tinta mineral e o trabalho é realizado pelas mulheres; no caso das cuias, a técnica para gravar os desenhos é a pirogravura e os homens também podem realizar este tipo de acabamento; no caso dos trançados, a atividade é essencialmente masculina; e, na pintura corporal, emprega-se tinta vegetal (sumo de jenipapo) e a atividade é exclusiva das mulheres ${ }^{34}$

Os desenhos, elemento gráfico, e o suporte, elemento plástico, devem ser tomados em conjunto. Como argumenta Müller (1993, p. 207), não se pode distinguir entre confecção e decoração de um objeto, uma vez que ele é concebido em sua totalidade, o que é expresso na nomenclatura de alguns deles, como por exemplo a biaakwasiat (biaava $=$ esteira e kwasiat= desenho) ou pyrypemkwasiat $($ pyrypem $=$ peneira e kwasiat $=$ desenho $)$.

Os desenhos, que existem em uma superfície supostamente infinita e imaginária, são aplicados a partir de formas específicas e sobre superfícies definidas por meio de técnicas e estilo próprio. Segundo Müller (1992, p. 240), a técnica de repetição contínua (ou variação de uma unidade mínima do desenho ou de um padrão) e o recorte do desenho infinito indicariam um princípio de

\footnotetext{
${ }^{34}$ Além de Müller $(1992,1993)$, outras antropólogas se dedicaram a investigar o tema da cultura material asuriní. Fabíola Andréa Silva (2000) realizou uma rica etnografia da produção da tecnologia cerâmica de uma perspectiva etnoarqueológica, e Berta Ribeiro (1984-85) investigou afinidades tecnológicas na tecelagem de quatro grupos do tronco tupi, dentre eles os Asuriní e, em outro trabalho (1982), refletiu sobre o papel da mulher Asuriní nas atividades da oleira e da tecelã
} 
percepção visual que enquadra o desenho infinito em uma forma tridimensional, recortando-o em determinado objeto. Essa característica dá aos desenhos um aspecto de "janela para o infinito", comum também aos Kaxinawá. Outro princípio identificado pela autora é o do ordenamento do espaço por meio da geometrização total, que corresponderia à técnica do negativo/positivo; as imagens seriam produzidas pelo contraste entre claro/escuro e fundo/superfície. O exemplo fornecido por Müller é explicativo: "[...] os Asuriní identificam um conjunto de constelações pela imagem de uma onça atacando um veado. Entretanto, não são os pontos luminosos que delineiam as figuras, mas sim os espaços negros entre eles, como os Asuriní nos ensinam ver" (Müller, 1992, p. 240).

Embora compostos por formas abstratas, para Müller os desenhos fazem referência a elementos de três domínios: natureza, cultura e sobrenatural. Relações entre esses domínios seriam explicitadas pelas nomenclaturas dos desenhos. Aqui há uma distinção importante entre padrão, entendido no sentido de regra formal, correspondendo ao sobrenatural, noção abstrata da qual o padrão tayngava é a forma preponderante, e os motivos a que cada desenho se refere, que estariam relacionados aos domínios da natureza e da produção cultural. Na estrutura formal dos desenhos "[...] o 'padrão', correspondente ao sobrenatural, é o eixo determinante (regras) de realização dos desenhos com vários significados relacionados à natureza e à cultura; o motivo, correspondente ao nível do conteúdo, faz referência aos três domínios cósmicos; e o 'desenho' corresponde à 'frase' realizada por meio dos veículos (suportes)" (Müller, 1992, p. 241).

Enquanto o padrão seria, quase sempre, o tayngava, os motivos podem variar bastante, por exemplo tembekwareropitá (base do enfeite labial), ipirajuak (pintura de peixe), tamakyjuak (pintura da perna), kwasiarapara (nome de um sobrenatural), tayngavi (tayngava pequeno), dentre outros. Como pode ser observado na imagem seguinte, um mesmo desenho pode ser denominado pelo padrão e pelo motivo, tayngava e ipirajuak, respectivamente. 

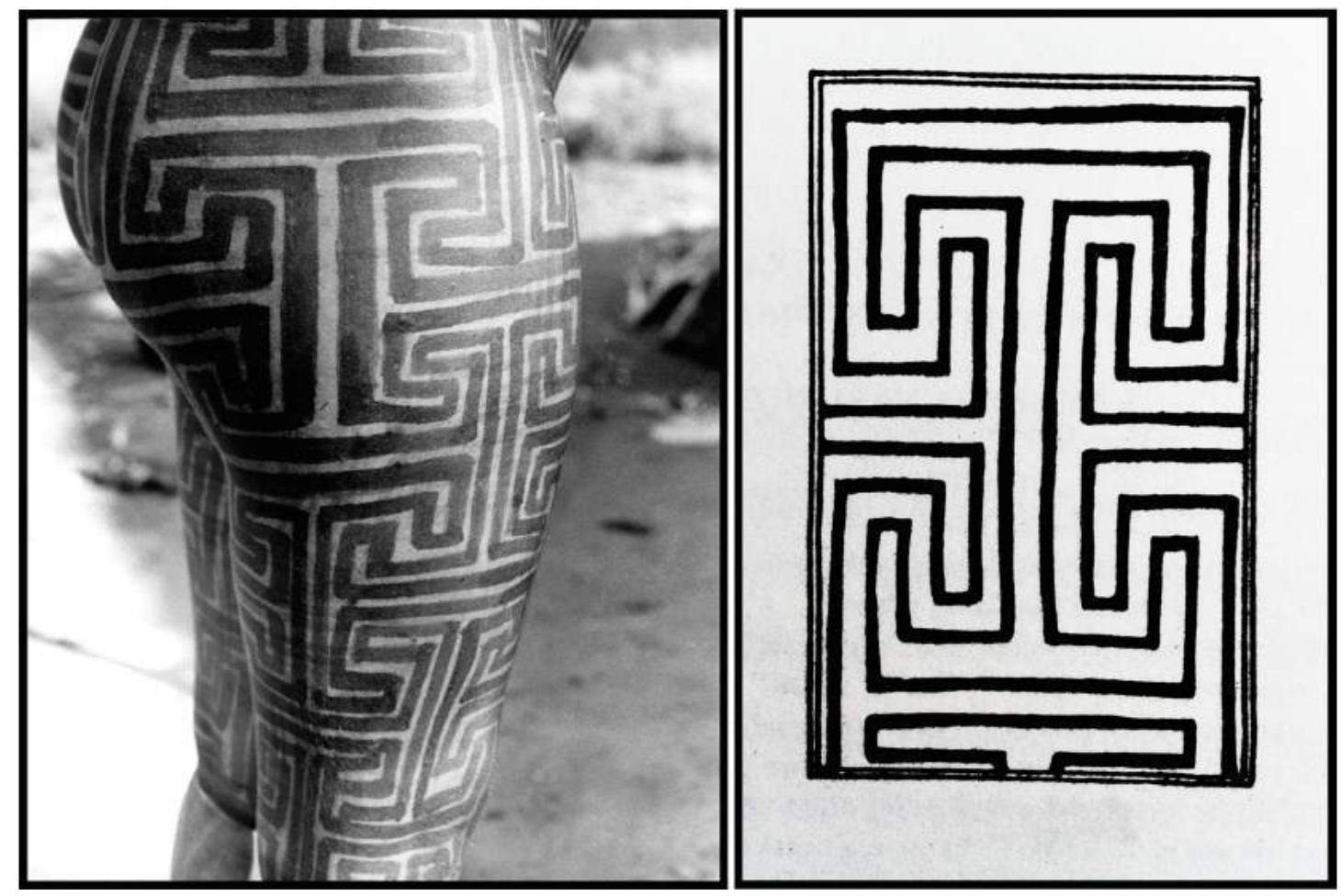

Imagem 1

Padrão tayngava e motivo ipirajuak.

À direita, motivo reproduzido em papel (Fonte: Müller, 1993, p. 238) e, à esquerda, o mesmo motivo aplicado na pintura corporal (Foto: Renato Delarole).

Nos processos de aprendizagem do desenho, o tayngava é o "a-e-i-o-u" dos Asuriní e as meninas treinam desde pequenas a desenhar esta figura (Müller, 1992, p. 241). 0 padrão da maior parte dos desenhos gráficos asuriní é a forma elementar da grega (ângulo de 90 graus) e pode ser considerado como o traço mínimo da figura antropomórfica (seus braços e pernas), como a identificam as mulheres Asuriní (Müller, 1993, p. 244). A palavra tayngava é formada pela raiz ayng, que, como veremos, diz respeito a imitação, réplica, medida, imagem; o sufixo $a v(a)$ é nome de lugar ou instrumento; e o prefixo " $t$ " indica o possessivo humano, sendo uma possível tradução para tayngava "imagem do ser humano". No entanto, o ser humano aqui remete ao sobrenatural e deve ser entendido de forma ampliada e, embora a figura antropomórfica nos remeta à forma humana, nos diz das intencionalidades e das qualidades de pessoa humana comuns a humanos e não humanos, o que fica evidente a partir da passagem: "Na mitologia, os heróis criadores são humanos; os animais têm forma humana e os espíritos atuais são antropomórficos. Dizem os Asuriní, a respeito destes seres, que todos 
eram avá (gente, humano) no passado mítico. 0 homem, portanto, está no centro do pensamento asuriní: o homem é a imagem do ser. Tayngava" (Müller, 1993, p. 250).

A pintura corporal asuriní, atribuída às mulheres que a realizam exclusivamente com sumo de jenipapo, cobre a pele com motivos gráficos de cor preta e é feita cotidianamente para "decorar" os corpos. Contudo, como bem observa Taylor (2010), a palavra "decoração" não parece apropriada para este gênero de atividade pois, entre os ameríndios, a beleza das pinturas é menos reconhecida por sua qualidade ornamental que por sua realização, a adequação perfeita a uma função e a um modelo estabelecido, bem como a qualidade que adquirem os corpos pintados.

Müller, nos anos 1990, interpretou a pintura corporal asuriní como representativas das diferentes posições na organização social, divisão entre grafismos que podem ser aplicados aos corpos de mulheres e de homens, e distinguindo grupos etários. A análise que faz a autora dos desenhos está associada a hipóteses linguísticas, "[...] desenhos possuem significado e sua elaboração segue a gramática própria desse sistema de comunicação, obedecendo regras estéticas e morfológicas" (Müller, 1992, p. 231), como se os grafismos formassem um texto ou um código a ser interpretado. Estudos recentes ${ }^{35}$ tem mostrado que o desenho (motivo gráfico) não parece ser codificado por estruturas verbais nem reenviar aos referentes objetivos. Seus nomes, em inúmeros casos, são atribuídos a posteriori e parecem estar desprovidos da preocupação primeira de representar referentes externos. Os nomes, que evocam referentes externos, parecem estar mais a serviço de uma técnica mnemônica de rememoração de motivos discretos em uma série do que apontar para a relação com o referente externo.

O termo ikwasiat é empregado, igualmente, para designar a escrita dos brancos. Tal acepção nos permitiria, de imediato, questionar o senso comum de que os Asuriní, como outros grupos ameríndios, são sociedades ágrafas, questão que colocam Vidal e Lopes da Silva (1992, p. 293) no texto de fechamento da obra Grafismo Indígena, ao apontarem para os grafismos como potentes sistemas de

35 Ver, por exemplo, Cesarino, 2012 e Déléage, 2007, dentre outros. 
comunicação visual que permitem o exercício da memória social. Ao falar de memória e imagens, Severi (2003, p. 77) questiona por que nós chamamos apenas de "orais" as tradições de povos que não utilizam a escrita. Assim como outros etnógrafos, o autor se esforça em mostrar que estas tradições são freqüentemente iconográficas, bem como orais, tanto fundadas na imagem quanto na palavra. $\mathrm{O}$ autor demonstra como é falaciosa a oposição entre os domínios oral e escrito e trata da imagem e do discurso oral de forma articulados como uma "técnica da memória".

Como aponta Cesarino (2012), a relação entre escrita e grafismo é mais complexa do que se imagina. Déléage (2011) observa que a utilização dos termos que fazem referência aos motivos gráficos para nomear a escrita entre diferentes povos ameríndios pode partir do reconhecimento de uma afinidade fenomenológica entre as duas expressões, ao utilizar as linhas em ziguezague para imitar a escrita dos brancos. Cesarino mostra que entre os Marubo o desenho produz uma pessoa, capaz de reproduzir palavras, enquanto a escrita só pode produzir palavras e não corpos de pessoas.

Ikwasiat e tayngava, relações entre grafismo e figuração

Se a noção de ikwasiat nos remete aos desenhos gráficos, as representações figurativas estariam mais próximas do domínio do que é ayngava, o que inclui imagens fotográficas e fílmicas, como demonstram os Asuriní ao se referirem às novas imagens advindas com o contato. Lagrou já havia notado que “[o]s ameríndios que distinguem conceitualmente grafismo e figuras tendem a associar o primeiro à escrita dos brancos e os segundos ao domínio dos duplos, como os reflexos na água ou no espelho, as fotos, os filmes e os 'espíritos'" (Lagrou, 2011, p. 77, tradução minha).

No entanto, entre os Asuriní se passaria algo diferente. Em vez de distinguir grafismo e figuração, como fazem os Kaxinawá, Piro, Wayana e Waujá, dentre outros, os Asuriní percebem a figuração do invisível como parte integrante da "unidade mínima de significação" que é o motivo tayngava, presente na maioria das pinturas corporais. Lagrou afirma que "[p]ara os Asuriní, 
o grafismo se transforma aqui claramente numa figuração virtual, permitindolhes, a partir de índices mínimos, completar mentalmente a imagem da tayngava [...]"36. 0 caso asuriní é paradigmático no que tange à passagem da abstração para a figuração, pois aqui toda a abstração já aponta para a figuração, e a imagem aflora entre as linhas do grafismo que aderem ao corpo e às vasilhas de cerâmica. A verdadeira figura se formaria quando os xamãs fabricam o boneco antropomórfico minimalista, o tayngava, para uso nos rituais xamanísticos (Lagrou, 2013, p. 95).

No artigo "Arte gráfica Asuriní do Xingu, corpo, mito e pensamento", Müller (2013) dialoga com recentes discussões sobre abstração e figuração nas artes ameríndias ${ }^{37}$. Com base no estudo sobre mitologia asuriní, performance ritual e sistema de arte gráfica, a autora propõe que se pense a relação entre a abstração - do grafismo no corpo decorado com desenhos geométricos - e a figuração - no desempenho performático do corpo decorado com a pintura ajemo'ona (corpo todo preto). Ela demonstra como a aplicação do abstracionismo geométrico enfatiza e realiza a condição humana, e de que maneira a figuração do corpo em movimento, pintado todo de preto e decorado com penugem de gavião, promove a incorporação de seres míticos e sobrenaturais no ritual apontando para a "(re)presentação figurativa".

Lagrou indica algo semelhante entre os Kaxinawá, que diferenciam grafismos (kene kuin) de figurações (dami). As pinturas dami transformam e mascaram a identidade de seu portador, enquanto as kene kuin o fabricam, o que permite que a autora identifique dois fenômenos diferentes: um que revela a fabricação de um corpo específico, kaxinawá, e outro, que revela as tecnologias de "alterização" (altérisation), que são empregadas durante os rituais, como, por

\footnotetext{
${ }^{36} \mathrm{~A}$ autora continua dizendo que, enquanto figuração virtual, "o tayngava permite completar mentalmente a imagem virtual dos espíritos a'anga" (2013, p. 95). Desconheço o uso desse termo em referência aos espíritos; estaria mais próximo da ideia de imagem, raiz ayng. Como já foi explicitado, o tayngava reenvia a intencionalidades e qualidades da pessoa humana compartilhadas com não humanos.

37 Para um panorama deste debate, ver o artigo de Lagrou publicado pela revista Gradhiva em 2011, e também os demais artigos da coletânia Quimeras em diálogografismo e figuração na arte indígena, organizada por Severi e Lagrou, publicada em 2013.
} 
exemplo, procedimentos que transformam as pessoas em espíritos da floresta a partir do emprego de vestimentas, pinturas e folhas, e que implicam agenciamentos de perspectivas (Lagrou, 2011, p. 70-71).

Alguns autores afirmaram que os ameríndios, sobretudo na Amazônia, produzem pouca figuração (Cf. Lagrou, 2007, 2011; Taylor, 2010). Lagrou se pergunta se os amazônicos seriam "iconófobos" (iconophobes), e sugere que a utilização generalizada da abstração, e evidentemente da representação figurativa nas expressões bidimensionais amazônicas, explicam-se pelo fato de que os motivos ajudam a constituir as superfícies que contêm os corpos (ou são aplicadas sobre tais superfícies), e não representam corpos, o que sugere que o desenho é um elemento fundamental na fabricação da pele ou da superfície dos artefatos em geral (Lagrou, 2011, p. 76).

Taylor vai dizer que os ameríndios não são apenas pobres em objetos de arte, mas em objetos de uma forma geral. Contudo, são ricos em saberes técnicos que produzem objetos de curta duração, e fabricam uma quantidade enorme de ferramentas a partir de produtos coletados na floresta, tais como armadilhas, cestos para carregar a caça recém-abatida, abrigos, dentre outros, os quais abandonam após um único uso. Estes objetos circulam e não são transmitidos a outras pessoas, sendo, geralmente, ligados a seu fabricante: reagem à vontade e ao pensamento de seu proprietário e apenas a ele, atuando como um prolongamento de seu corpo, sendo frequentemente destruídos após sua morte (Taylor, 2010).

No caso dos objetos de arte tais como máscaras, efígies e bonecos, sobretudo utilizados nos rituais, eles evocam qualidades e propriedades notadamente qualidades de pessoa próprias a entidades não humanas - e presentificam entidades invisíveis, sejam espíritos ou mortos. Sem entrar em detalhes a respeito de como procede cada tipo de objeto ao "figurar o invisível", nos interessa pontuar que, de todo modo, os objetos não representam as entidades não humanas mas estão a serviço de presentificar forças, evocar capacidades e partilhar intencionalidades. Esta foi a ênfase dada aos objetos apresentados na exposição Fabrique des Imagens, realizada no Museu du quai Branly em Paris entre 2010 e 2011, sob a curadoria de Phillipe Descola. 
A ênfase na agênca destes objetos estaria no próprio conceito de figuração formulado por Descola. Com a exposição, o autor do modelo das quatro ontologias pretendeu demonstrar (eu diria, de forma audaciosa) de que maneira objetos de arte do mundo todo podem revelar propriedades ontológicas animistas, totemistas, naturalistas e analogistas. 0 curador entende figuração como

[...] esta operação universal por meio da qual um objeto material qualquer é investido de forma evidente por uma "agência" (no sentido do inglês agency) socialmente definida, após uma ação de dar forma [façonnage], desenvolver [aménagement] e ornamentar, ou da criação de uma situação visando lhe dar um potencial de evocação icônica de um protótipo real ou imaginário, que ele denota de maneira indicial (por delegação da intencionalidade), jogando com uma semelhança direta de tipo mimético ou com qualquer outro tipo de motivação identificável de maneira mediada ou imediata (Descola, 2006, p. 167, tradução minha).

A perspectiva adotada para a compreensão do que ele chama de uma "antropologia da figuração" (Op. cit., p. 167) é a intencionalista, desenvolvida por alguns autores, entre eles Alfred Gell (1998) ${ }^{38}$, segundo a qual a melhor maneira de entender um objeto de arte é tratá-los, não por sua significação ou segundo critérios de beleza aos quais devem corresponder, mas sobretudo como agentes que podem causar efeitos sobre o mundo.

$\mathrm{Na}$ forma de figurar animista, se quisermos fazer o exercício pensando nos Asuriní, a questão passa por tornar visível a interioridade de diferentes tipos de existentes, e mostrar que esta interioridade comum se situa nos corpos de aparências diversas que devem ser identificados pelos índices de espécies. Seria este o motivo pelo qual encontramos, no regime animista, imagens compósitas ou objetos antropomórficos que evocam intencionalidades e subjetividades dos não humanos (Descola, 2006, p. 174), como mostram as máscaras dos Wauja do Xingu e as dos Yup'ik do Alasca, ou as miniaturas produzidas entre os Inuit do Canadá.

O tayngava, enquanto objeto antropomórfico que abriga o princípio vital,

${ }^{38}$ Além de Bakewell (1998), Freedberg (1989) e Schaeffer (1996). 
se aproximaria das efígies (como modalidade de figuração) encontradas no Xingu e em outros contextos da América Indígena, que também possuem identidades indefinidas possibilitando que sejam suportes provisórios de uma série de personagens sobrenaturais (Cf. Taylor, 2010).

Não apenas a discussão da figuração, mas também reflexões entre grafismos e figuração, parecem passar pelo tayngava, tomado aqui em sua acepção de padrão das pinturas (e também de boneco antropomórfico) que coloca em relação noções de ikwasiat e ayngava, pois é ao mesmo tempo um padrão de desenho (ikwasiat) e uma imagem que remete a uma figura (ayngava). Resta-nos, ainda, aprofundar um pouco mais a noção de ayngava, o que faremos na próxima seção.

Ayngava, imitação e perigo

Ao descrever como se dá a "incorporação de personagens míticos" no ritual Turé, através da figura do corpo todo pintado de preto e decorado com penugem de gavião, Müller diz que "[r]eceber a penugem de gavião requer muita concentração. Pode-se ter tontura e até ficar doente, sinal deste contato, perigoso principalmente para os jovens" (Müller, 1993, p.111). A pintura ajemo'ona e as penas de gavião são tecnologias de transformação do corpo no ritual. A figuração dos seres míticos permite investir os corpos dos avá (gente) de capacidades relacionadas aos espíritos, estabelecendo um contato, muitas vezes perigoso, entre a pessoa e estes seres dos quais se partilham as qualidades.

Contudo, não é apenas em contextos rituais que a aproximação aos espíritos pode apresentar riscos. Em alguns casos, justamente por não estar relacionada à atividade ritual, a partilha de qualidades adquiridas por imitação destes seres pode trazer ainda mais prejuízos. Ao me contar sobre o ensino de elementos dos rituais Turé e Tauva na escola indígena, o índio Koatireí me disse que nas atividades em sala os professores podem contar as histórias relacionadas ao personagem Tauva, falar sobre os objetos usados no ritual, mas não podem ensinar os cantos que as tauyva (cantadoras que entram em contato com os 
espíritos) executam sob o risco provocar reações descontroladas do espírito Tauva, que seriam sentidas pelas cantadoras. Como me explicou o jovem professor, reproduzir o canto é uma forma de imitar (ayng) o movimento das tauyva que, ao cantar, estabelecem contato com os espíritos Tauva. Dessa forma, se alguém reproduz seus cantos, pode evocar os espíritos de maneira desgovernada.

A imitação de alguns animais como a coruja (urukure'a), o inhambu (inamu) e o $u r u^{39} \mathrm{em}$ determinadas circunstâncias pode representar riscos. De noite na mata não se pode imitar a coruja (nayngavi urukure'a), pois ela se transforma em onça e vem atacar quem a chamou. A explicação para a interdição me foi fornecida pelo jovem xamã Parajuá, que diz: "Coruja já comeu gente" e recorreu à história de Tivaruma ${ }^{40}$ para se fazer entender. No início da narrativa: "Tivaruma vai no mato com seus parentes. Os parentes dele estavam brincando, imitando coruja. A coruja veio na forma de todo tipo de onça e comeu os parentes de Tivaruma. Só ele sobreviveu pois estava virando pajé". A história segue e Tivaruma, sozinho (sem parentes), passa por inúmeras peripécias até encontrar o caminho de Tivá.

Ao repetir a história de Tivaruma com mais detalhes, Parajuá utiliza o verbo "chamar" (ejat) ao invés de "imitar" (ayng) a coruja. Os parentes de Tivaruma teriam chamado a coruja ao imitá-la. 0 perigo de imitar certos animais ou espíritos consiste no fato de que, ao imitá-los, estamos evocando-os, o que nos torna extremamente suscetíveis a suas ações predatórias. 0 espírito Tauva não pode ser imitado (nayngavi Tauva) na beira do rio sob o risco de os peixes virarem todos Tauva. Caso alguém imite o inhambu ou o uru de noite eles vêm e viram anhynga, aparecem em forma de pedaços de corpos de gente que já morreu. Não se pode imitar o espírito Karovara na beira d'água, sob o risco de ele cortar o corpo da pessoa por dentro, levando-a à morte.

\footnotetext{
${ }^{39}$ Não pude obter o nome deste animal na tradução em português. Sei que se trata de uma ave aparentada ao inhambu, mas um pouco menor.

40 Tivá é um espírito que no tempo mítico era xamã; por isso, pode ser chamado de espírito xamã primordial. 0 Tivá vem nos rituais para tomar mingau e fornecer ynga $e$ moynga aos doentes. Xamãs que "têm Tivá" trazem esses espíritos para a aldeia e também convivem em seus mundos, casando-se e tendo filhos com eles. Tivaruma é o que vai se tornar Tivá. 0 sufixo ruma corresponde ao futuro nominal, "o futuro Tivá".
} 
Imitar na língua asuriní é ayng ${ }^{41}$ : jeaynga, eu imito; janejaynga, nós imitamos; e gauaynga, ele imita; tapy'yia ukanu uaynga, índio bravo imitou gavião. Na palavra ayngava, à raiz ayng é acrescido o sufixo $a v(a)$, que Müller (1993, p.242) define como sufixo formador de nome de circunstância. Uma tradução um pouco diferente para o sufixo av é fornecida por Ruth Monserrat, na publicação em que tece observações acerca da língua asuriní; ela define av como "nome de lugar ou instrumento", e o complemento (a) é um outro sufixo nominal. Monserrat (1998, p. 35) cita alguns exemplos: a oração ki je kiava (aqui é meu dormitório, lugar de dormir) ou a palavra kywava (pente, objeto para piolho), ou ainda, tevutiava (banheiro, lugar de cagar). Dessa forma, uma tradução mais conveniente para ayngava poderia ser "objeto (ou instrumento) que imita", ou "lugar da imitação", para a acepção relacionada a lugar, que Müller também enfatiza ao propor falar de $a v$ como sufixo formador de nome de circunstância.

Neste trabalho, o sentido de "objeto ou instrumento que imita" me parece extremamente apropriado para pensar as imagens técnicas produzidas pelos brancos, até porque, como procuramos mostrar, não é possível pensar em imagens entre os ameríndios sem dar ênfase aos objetos, suportes que materializam as imagens. Como me explicou o jovem Parajuá, ayngava pode ser utilizado para designar imagens fotográficas e fílmicas porque "elas imitam de verdade". Embora Müller tenha traduzido ayngava diretamente por "imagem, réplica e representação" (1993, p. 245) e, ainda que eu julgue ser uma tradução apropriada, creio ser importante recuperar a acepção da palavra "imitação", raiz do verbo ayng presente no termo ayngava. Opto, aqui, pela tradução do termo como "objeto que imita" ou "imitação", ao lado do termo "imagem".

Podemos pensar que, ao agregar a palavra "imitação" à tradução de ayngava, nada de muito novo é adicionado. De fato, diferentes noções de imagem (inclusive as ocidentais) associam primeiramente imagem àquilo que se assemelha, se parece, imita e reproduz o modelo. A questão aqui me parece ser mais a de circunscrever que relações podem ser estabelecidas por imitação e que tipo de relação se estabelece, ou pode se estabelecer, entre o protótipo ou o referente e a pessoa ou o objeto que o imita. Imitar estaria mais próximo de

\footnotetext{
${ }^{41}$ Copiar seria referido como "peapai jave" (fazer igual).
} 
noções de mimesis, de partilha de propriedades e de evocação das qualidades do protótipo - como desenvolvidas por Taussig (1993) ou por Vernant (1990[1973]) quando fala dos ídolos da Grécia Antiga - do que a mera imitação da aparência.

Todavia, é preciso que se diga que não é em todos os contextos que imitar implica investir o objeto de capacidades do original. No uso cotidiano o termo ayngava pode ser empregado para designar uma reprodução ou uma réplica de qualquer objeto. Dessa forma, o desenho de um homem (ava) é avarayngava, ou a representação estilizada de um pássaro (uirá) é chamada uirarayngava. Um outro exemplo sobre os usos correntes do termo ayngava é a maneira como os Asuriní se referem às cédulas de dinheiro. Para identificar notas de 10, 20, 50 e 100 reais eles se reportam às figuras representadas em cada unidade de papel. A nota de 100 reais, que traz o desenho do peixe tucunaré, é referida como tucunarerayngava; a de 5 reais, com a imagem da arara, é ararayngava; e assim por diante.

Tal constatação, exemplificada anteriormente, não enfraquece a ideia da imitação como partilha de capacidades e propriedades; pelo contrário, ela nos auxilia a circunscrever as ocasiões em que imitação e perigo operam. Em situações rituais ou extrarrituais, em que são evocados seres e espíritos, tal noção parece se efetivar. De maneira semelhante, máscaras, efígies e miniaturas ameríndias que figuram o invisível não presentificam intencionalidades humanas a qualquer momento ou em qualquer situação; isso acontece, sobretudo, nos momentos rituais, o que não impede que estes objetos e imagens carreguem com eles a potencialidade de agir e de que, a qualquer momento, algo aconteça.

0 mito do desenho nos fornece mais um caso em que a imitação produz efeitos. Esta narrativa conta como os antigos (bava) adquiriram o grafismo geométrico (ikwasiat) por meio de anhynga, o "dono do desenho". A história relata como os padrões geométricos passam do corpo Anhyngakwasiat para diversos objetos trançados. Anhynga aparece aqui como o herói cultural que ensinou o desenho aos bava, antigos Asuriní que já morreram.

Nas diferentes versões que obtive da narrativa a mesma estrutura se repete: Anhyngavuí, sobrinho de Anhyngakwasiat, fascinado pelo corpo decorado do tio, pede a sua mãe que o ajude a copiar os desenhos. Ele, então, cria uma 
estratégia para ver e copiar os desenhos do corpo de Anhyngakwasiat: mata um veado e depois uma anta e põe no caminho do tio, e, enquanto Anhyngakwasiat briga com o animal morto, o sobrinho, sem ser percebido, copia os desenhos do corpo para objetos trançados: arco, flecha, peneira, cestos.

Há um detalhe importante a comentar. Como esclarece Müller (1993), os desenhos geométricos no corpo de Anhyngakwasiat não obedecem às regras de preenchimento das partes do corpo que distinguem gênero e anatomia humana e não respeitam os limites que dividem tronco, mãos, pernas e pés. Diz Müller: "No corpo de anhynga não há unidade, há a junção de partes como uma colcha de retalhos estampados formando a pintura e o próprio corpo do tio de Anhyngavuí. Por outro lado, entretanto, há um corpo-tensão entre a unidade e a divisão [...]" (1993, p. 265). A tensão se expressaria entre a unidade (o corpo) e seus pedaços (os vários desenhos). Portanto, anhynga aparece aqui associado à multiplicidade e à presença (de desenhos que compõem a pintura de seu corpo). Em outras situações, anhynga é associado à ausência e à divisão pois se refere também aos espectros que são liberados após a morte e também aos pedaços do corpo do morto (braços, pernas, coração, etc.) que aparecem em algumas outras narrativas míticas, como no relato de Kavara e de Apykwara (que serão explorados no próximo capítulo). 0 que nos interessa é remarcar, como observa Müller, (2013, p. 176-177) que a "categoria" de anhynga se refere à multiplicidade e à presença, bem como à ausência e à divisão sem oposição (mas com tensão, por exemplo na unidade do corpo de Anhyngakwasiat e junção e divisão pelos desenhos fragmentados), os anhynga são tudo isso ao mesmo tempo ${ }^{42}$.

Duas das versões desse mito que ouvi em campo foram narradas por mulheres com mais de 60 anos, Marakauá e Burí, e correspondem, quase

\footnotetext{
42 Figura presente em diversos povos tupi, aparece nos relatos de cronistas como "Anhanga" ou "Aignan" tupinambá, e também ligados às "almas errantes dos mortos". Mas em mitos tupinambá, apapokuva e tenetehara são "personagens da mitologia" e "seres malfazejos terrestres", e, entre os Wajãpi, ligados a noções de força mágica. Viveiros de Castro afirma que entre seres mitológicos e espectros terrestres, a noção de Anhanga tem relação com os Outros, tomando aqui os mortos como Outros, e que a ambigüidade dessas figuras, entre seres míticos (positivos) e espectros terrestres (associado à podridão, selvageria), aponta para a ambivalência radical da posição do Outro na cosmologia tupi-guarani. Ver Viveiros de Castro, 1986, p. 255-256.
} 
totalmente, à versão registrada por Müller ${ }^{43}$. No entanto, as duas mulheres adicionaram uma passagem ao final do mito que não foi registrada por Müller e que concentra um ponto importante, objeto da minha análise.

Marakauá e Burí contaram que Anhyngavuí só não conseguiu copiar um desenho, o da barriga do tio, pois ele estava sentado. 0 sobrinho tentou mas não obteve resultado. Empenhou-se novamente e nada, sem êxito. Vendo que não conseguia, Anhyngavuí começou a chorar. 0 desenho chamado anhynga jaava (jaava = chorar) fez mal a ele e é por isso que, até hoje, os Asuriní não podem reproduzir esse desenho em seus corpos, correndo o risco de sofrer as conseqüências dos efeitos negativos a ele associados ${ }^{44}$.

0 que nos interessa com essa narrativa não é explorar a origem do desenho (ikwasiat) e suas formas de transmissão, tema já abordado por Müller (1993, 2013), mas examinar a passagem final do relato que aponta para os perigos envolvidos na reprodução dos desenhos da barriga do ancestral mítico. De certa forma, como alertaram as narradoras, reproduzir o desenho da barriga de Anhyngakwasiat implica reeditar a própria situação em que ele ficou ao tentar copiar o desenho; o sobrinho ficou triste e chorou, e é por isso que não se pode fazer este desenho. Portanto, está colocado no mito (justamente no mito do desenho) que a atividade de imitar, reproduzir e copiar pode representar riscos.

\subsection{Termos, usos e apropriações das imagens técnicas}

Termos asuriní para as novas imagens

As primeiras menções ao modo como os Asuriní se referem aos equipamentos e tecnologias de produção de imagens e sons dos brancos aparecem no artigo de Müller: "Corpo e imagem em movimento: há uma alma neste corpo", publicado em 2000 pela Revista de Antropologia. A devolução de

\footnotetext{
43 Ver Müller 1993, p. 252-253. Para uma análise do mito do desenho em conjunto com o mito do Kavara, ver na mesma obra as páginas seguintes, 253-272.

${ }^{44}$ As mulheres pareciam não querer ou não saber me dizer como é este desenho. Compreendi que, se ele não foi copiado, de fato não se sabe como é, e, de outro modo, se ele faz mal, não deve ser reproduzido.
} 
imagens em vídeo, registrando sobretudo rituais asuriní produzidas na década de 1990, bem como a exibição de filmes de ficção e de produções realizadas entre outros grupos indígenas 45 , é o pretexto para a reflexão sobre o uso da imagem em movimento na pesquisa antropológica, transmissão de conhecimento através das práticas rituais no contexto intercultural e noções de representação e imagem na arte asuriní (Müller, 2000, p. 176).

Após os primeiros dias de exibição de filmes, os Asuriní, de maneira sagaz e pragmática, acrescentaram ao roteiro inicial de captação das imagens - que registrava, até então, conversas com os índios a partir dos temas levantados pelos filmes e também sobre a transmissão dos conhecimentos - a iniciação de um xamã, para que ficasse registrado, "para não perder como se faz pajé". A "festa do veado", Arapoá, ritual xamanístico que invoca espírito do mesmo nome, seria realizada para que o índio Takamuim se tornasse um xamã (Op. cit., p. 177).

$\mathrm{O}$ vídeo Morayngava, produzido no âmbito do projeto Vídeo nas Aldeias e do Centro de Trabalho Indigenista - CTI, como resultado desta incursão ao campo em que colaborou, também, a antropóloga Virgínia Valadão, apresenta o ritual de iniciação de Takamuin bem como depoimentos e entrevistas acerca do tema da transmissão dos saberes tradicionais, além da avaliação dos Asuriní a respeito do uso de tecnologias dos brancos a serviço da "reprodução da cultura". Equipamentos de registro de imagens e sons poderiam "pegar a cultura" para ser transmitida para as novas gerações"(Müller, 2000, p. 178).

Diante da câmera e da televisão, os Asuriní, diz Müller, "[...] reelaboram os conceitos ynga e ayngava, princípio vital e imagem, 'alma'/sombra e desenho, bem como suas concepções sobre captação de imagem e morte/'perda da alma'" (Op. cit., p. 175). Além disso, os nomes dados pelos Asuriní à televisão, à imagem em movimento e à câmera de vídeo permitem algumas considerações sobre a experiência do contato dos índios com um instrumento tecnológico que, segundo Müller, logo incorporaram como meio de aprendizagem e transmissão de conhecimento (2000, p. 184).

\footnotetext{
45 Vídeos do projeto Vídeo nas Aldeias que, na época, integrava o Centro de Trabalho Indigenista,- CTI, ao qual o projeto de Müller estava vinculado, além de filmes de ficção como, por exemplo, A guerra do fogo, do qual falaremos adiante.
} 
A reelaboração de conceitos nativos diante das novas imagens tem por efeito alargar suas possibilidades tradutivas. Por exemplo, nos depoimentos de Marakauá e Apebu: "oreayngava onhynhyn" e "oreynga pupé", cuja tradução apresentada é: "nosso desenho está entrando [na televisão]" e "nossa sombra fica dentro" (Müller, 2000, p. 175), os Asuriní traduzem oreayngava por "nosso desenho" e oreynga por "sombra" em comparação à sombra de um corpo no chão, como indicou Manduka. Mas a revisão dos termos não é esforço apenas dos índios, Müller também reelabora suas próprias definições do que seja ynga $e$ ayngava e apresenta uma outra equação para dar conta da construção "oreayngava onhynhyn" e "oreynga pupé", que é a seguinte: "[...] entre o corpo e a imagem em movimento na TV há uma alma, desenho e sombra" (Op. cit., p. 175). 0 termo "alma" aparece como alternativa de se traduzir o ynga por "sombra" - o que é evidenciado pela tradução de "televisão" no filme por "caixa da alma" - ao mesmo tempo que agrega uma nova camada de sentido pois a "alma" estaria na junção do "desenho" e da "sombra".

Informada por este primeiro levantamento realizado por Müller, fui a campo investigar novos termos empregados pelos Asuriní para se referirem às imagens e sons produzidos pelas tecnologias dos brancos, e confirmar as possibilidades tradutivas existentes. A seguir, apresento uma tabela com os termos listados contendo as traduções correspondentes, elaboradas por mim a partir de conversas e depoimentos indígenas, e, na seqüência, comento os termos nativos empregados. 
Tabela de termos asuriní para as tecnologias de produção de imagens e sons dos brancos

\begin{tabular}{|c|c|c|}
\hline Instrumento ou objeto & Termo asuriní & Tradução \\
\hline $\begin{array}{l}\text { Câmera fotográfica e } \\
\text { câmera filmadora }\end{array}$ & moresakava & $\begin{array}{l}\text { "aquele (objeto) que vê" } \\
\text { "aquela máquina que vê" }\end{array}$ \\
\hline \multirow[t]{2}{*}{ Gravador e televisão } & yngyrú & "guarda o ynga" \\
\hline & nhe'engyrú & "guarda a fala" \\
\hline \multirow[t]{3}{*}{$\mathrm{CD}$} & yngyrú & "guarda o ynga" \\
\hline & nhe'engyrú & "guarda a fala" \\
\hline & ja'y uvayngava & "parece a cara da lua" \\
\hline \multirow[t]{4}{*}{ DVD } & yngyrú & "guarda o ynga" \\
\hline & ja'y uvayngava & "parece a cara da lua" \\
\hline & morayngava & $\begin{array}{l}\text { "aquele que imita as coisas", } \\
\text { "imagem das coisas" }\end{array}$ \\
\hline & $\begin{array}{l}\text { ayngava (antecedido por um } \\
\text { possuidor) }\end{array}$ & $\begin{array}{l}\text { por exemplo: janerayngava, } \\
\text { "nossa imagem, imitação da } \\
\text { gente" (se for filme dos } \\
\text { Asuriní) }\end{array}$ \\
\hline Pendrive & imuje'egava & "o que faz falar" \\
\hline Filme & morayngava & $\begin{array}{l}\text { "aquele que imita as coisas", } \\
\text { "imagem das coisas" }\end{array}$ \\
\hline \multirow[t]{3}{*}{ Fotografia } & $\begin{array}{l}\text { ayngava (antecedido por um } \\
\text { possuidor) }\end{array}$ & $\begin{array}{l}\text { por exemplo: bavarayngava, } \\
\text { "imagem, imitação dos } \\
\text { antigos". }\end{array}$ \\
\hline & morayngava & $\begin{array}{l}\text { "aquele que imita as coisas", } \\
\text { "imagem das coisas" }\end{array}$ \\
\hline & tayngava & "imagem de gente" \\
\hline
\end{tabular}


Müller já havia notado que os Asuriní se referem à câmera filmadora e fotográfica (e também ao espelho) pelo termo moresakava, traduzido como "o que vê as coisas", pois mor é prefixo de nome coletivo e sujeito indeterminado, uesak é ver e $a v(a)$ é sufixo formador de circunstância (Müller, 2000, p. 185). A tradução que Monserrat (1998) propõe para o sufixo $a v(a)$ como "nome de lugar ou instrumento" é bastante apropriada para pensar os termos associados às imagens técnicas, já que nesta acepção do sufixo há uma ênfase em nomear instrumentos e objetos. Moresakava, nome dado às câmeras filmadora e fotográfica e também ao espelho, poderia ser, desta perspectiva, "instrumento ou objeto que vê" ou "aquela máquina ou objeto que vê". Contudo, como me apontaram Parajuá e Muapé, embora o mesmo termo se refira ao espelho, entendido como "objeto para a gente se ver", no caso das câmeras haveria uma inversão na relação entre quem olha e quem é olhado, o que levou a traduzirem moresakava como "aquela máquina que olha a gente" semelhante à oresakava, "a máquina está olhando a gente". A ênfase dos índios no movimento e direção do olhar pode ser entendida com dados etnográficos concretos. Em mais de 40 anos de contato, apenas nos últimos dez os Asuriní passaram, ainda que timidamente, a incorporar o uso de equipamentos de produção de imagens; até então, esses instrumentos pertenciam aos brancos e o olhar era sempre unidirecional, de fora para dentro, câmeras olhando para eles.

A televisão foi aludida por meio do termo yngyrú, claramente em referência à "sombra" (imagem em movimento que a TV projeta) e à fala reproduzida, que, como vimos, é índice da presença do ynga. Parajuá foi categórico: "televisão é yngyrú porque a gente aparece e sai voz, a minha avó chamava assim". 0 prefixo yrú, segundo me explicaram, refere-se à ação de "guardar", colocar dentro (pupé); jeryrú, termo que utilizam para se referir à roupa, foi traduzido como "o que a gente usa para guardar o corpo". Koatireí falou em "coisa que guarda a alma", empregando a tradução de ynga por "alma", mesmo procedimento que Müller realizou no filme Morayngava ao se referir à televisão como "caixa da alma". Outro termo mais recentemente empregado para se reportarem à TV é nhe'engyrú, o que "guarda a fala dentro", como me explicou o velho Kwati. CDs e DVDs, suportes de imagens e sons, também seriam yngyrú, com a diferença que o DVD guarda o ynga enquanto sombra (imagem animada) e 
voz, e o CD, apenas a voz (ynga). CDs também foram aludidos por outras pessoas como nhe'engyrú.

Uma outra forma pela qual os velhos se referiram aos CDs e DVDs foi jay' uvayngava, "parece a cara da lua", devido ao formato redondo dos dois objetos. Koati me explicou que todas as máquinas e objetos dos brancos sobre os quais eu o questionava vieram depois do contato e, por não terem designação já estabelecida, acabam sendo nomeados a partir das semelhanças com outros objetos. Pendrive, um objeto extremamente novo nas aldeias, foi referido como imuje'egava, "o que faz falar". Ouvi Marakauá se referir também como "umbigo do som"; no entanto, quando lhe questionei os termos exatos na língua, ela ficou com vergonha e não quis me explicar.

Filmes podem ser referidos genericamente pelo termo morayngava, que Müller traduziu por "imagem das coisas" e que proponho possa ser também "aquele que imita as coisas", ou ainda, como sugeriu Muapé, "o que vai imitar". No caso de ser um filme dos Asuriní, eles diriam janerayngava (jane = nós). Os filmes nos suportes de DVD também podem ser referidos como morayngava, da mesma forma que fotografias (impressas ou digitais) de forma genérica. Fotos dos antigos Asuriní que já morreram (bava) são bavarayngava, e, se a pessoa que fala aparecer no retrato, vai dizer jerayngava (je,= minha, de $\mathrm{mim}$, eu). Fotografias nas cédulas de identidade são mencionadas como tayngava (fotografia de gente, ser humano, como me explicaram), ou, então, akynguerayngava, para se referir à imagem da cabeça (akynga) separada do corpo (fotos 3x4 dos documentos), o que é indicado pelo sufixo er, que indica passado (ex-cabeça) ou o estado de separação entre cabeça e corpo ${ }^{46}$.

\footnotetext{
${ }^{46}$ Er, per ou wer são sufixos de passado nominal, empregados para se referirem aos pedaços do corpo do morto enterrados, indicando que não estão mais integrados à pessoa, por exemplo "ex-cabeça" (akynguera).
} 
Usos, apropriações e reflexões suscitados pelo audiovisual ${ }^{47}$

Embora esta tese se debruce sobre a relação dos Asuriní com imagens fotográficas, não foi apenas a partir dessas imagens que se produziram reflexões e comparações por parte dos Asuriní entre os domínios da imagem nativo e não indígena. A presença ativa do audiovisual, em certos momentos, provocou reflexões e agenciamentos que evidenciam a maneira como os Asuriní pensam essas novas imagens à luz de referenciais próprios.

Para "fazer aparecer" as comparações asuriní e evidenciar alguns possíveis usos dessas imagens, abordarei situações distintas em que se registrou a presença do audiovisual na aldeia. A primeira se reporta à década de 1990, quando Müller e Valadão exibiram diferentes filmes e os Asuriní avaliaram positivamente o uso do vídeo na transmissão dos conhecimentos ("para guardar a cultura"), desencadeando um processo que tem repercussões até os dias de hoje. O segundo relaciona audiovisual e xamanismo e se reporta, tanto às comparações estabelecidas pelos índios entre filmes e narrativas míticas, esboçadas pela primeira vez em 1997, quanto a situações em que se realizaram filmagens de rituais xamanísticos.

\section{Guardar a cultura}

Nos anos 1990, quando as duas antropólogas realizaram as primeiras exibições do material gravado na aldeia em anos anteriores, além de filmes indígenas e não indígenas, os Asuriní ficaram impressionados, não apenas com suas próprias imagens registradas, mas também com as imagens de outros

\footnotetext{
47 Trato, nesta seção, de filmes de ficção (ver Müller, 2000), vídeos indígenas (produzidos pelo projeto Vídeo nas Aldeias, como o Morayngava), além do registro em sons e imagens de rituais asuriní pelo mesmo termo "audiovisual", sem diferenciar suportes, processos e técnicas. 0 apagamento das diferenças entre suportes e formas de registro se reporta à ênfase asuriní sobre a "imagem em movimento" (ynga) e a "voz" (ynga e nhe'eng), que são captadas na aldeia por câmeras filmadoras e exibidas, ou no caso das produções cinematográficas, apenas exibidas pela televisão, independentemente dos suportes e registros em que foram produzidas.
} 
ameríndios e com os filmes "dos brancos". Os índios rapidamente demonstraram, em seus depoimentos seguidos das exibições, a compreensão do potencial do vídeo na transmissão da "cultura". Apebu afirmou: "Pode pegar nosso canto/dança (oforahai), para quando nós morrermos as crianças poderem ver como fazíamos festa". Mará, uma outra índia, disse que a televisão pode "pegar sua cultura" para ser transmitida (Müller, 2000, p. 178-179). A ideia de registrar "a cultura" para que as crianças aprendam como os "mais velhos faziam" é um dado novo no momento histórico em que viviam os Asuriní, e aponta diretamente para mudanças significativas no modo de transmissão dos saberes rituais que, segundo depoimentos dos índios, se daria tradicionalmente "na prática", "no fazer", ao participarem das festas.

É preciso dizer que no momento em que foram enunciados os depoimentos dos índios, pouco mais de vinte anos após o contato oficial, diversas transformações se faziam sentir entre os Asuriní. A começar pelas conseqüências da ameaça de extinção física, causada por doenças e epidemias, que reduziu a população pela metade em dez anos - os Asuriní passaram de 100 indivíduos em 1971 a 52 em 1982. Nos anos 1980, diversos projetos de intervenção indigenistas foram implementados pela Funai (Fundação Nacional do Índio), em parceria com a Missão das Irmãzinhas de Jesus, para que o grupo implementasse políticas demográficas ${ }^{48}$ no sentido de alterar padrões tradicionais de procriação com vistas a aumentar a taxa de natalidade. As respostas aos projetos implementados puderam ser observadas ainda na década de 1980, quando se iniciou um processo de recuperação demográfica com certas especificidades.

Em 1997, Müller observa o aumento da população infantil com alteração na composição do grupo familiar (mais filhos por família nuclear), decréscimo nas faixas de idade de jovens e adultos (casamentos entre pessoas cada vez mais jovens), conformando uma pirâmide demográfica falha e invertida (Müller, 2000,

\footnotetext{
480 que foi viabilizado por meio de projetos de intervenção indigenista na área da saúde, especialmente o Projeto de Recuperação dos Assurini do Koatinemo/Funai/1978-1979 e o Projeto de Assistência à Saúde Assurini/Funai/Irmãzinhas de Jesus/-1980-1981. Fonte: http://www.trabalhoindigenista.org.br. Falaremos mais a respeito dos projetos de saúde no capítulo 4 pois o fotógrafo Renato Delarole também se envolveu em algumas destas ações.
} 
p. 172). Além disso, desde o contato oficial houve desaparecimento de vários xamãs e líderes de grupos domésticos e casamentos interétnicos (com índios Parakanã, Arara e Kararaô, que resultaram em novos padrões de relacionamentos, novos comportamentos sociais e rearranjos na participação em rituais e na liderança das demais atividades internas e externas do grupo. Diante dessa configuração social, Müller observou a dificuldade da participação das mulheres nos rituais (na função de uirasimé), que passaram a dedicar seu tempo a cuidar da prole cada vez mais numerosa, e a ausência dos homens nos papéis vanapy, espécie de auxiliar e produtor do ritual.

Mais de dez anos depois das primeiras formulações asuriní a respeito do potencial do audiovisual em "guardar a cultura", precisamente no ano 2007, novas imagens e sons dos "antigos" passam a circular na aldeia, desta vez por meio de projeto de apoio ao patrimônio imaterial realizado via edital do Iphan Instituto do Patrimônio Histórico Artístico Nacional, já mencionado anteriormente. Diante de cópias de gravações em áudio de cantos, fotografias e vídeos brutos de rituais, o discurso asuriní ressalta a importância do registro para "guardar a cultura" para as novas gerações, ao mesmo tempo em que listam outros rituais e cantos que gostariam de documentar. Estimulados pelo extenso material e aproveitando que eu estava em campo com uma câmera filmadora, os Asuriní decidem realizar o ritual para o espírito Apykwara, para cura e fortalecimento de algumas crianças que se encontravam, naquele momento, enfermas. A festa durou dois meses e, a pedido dos índios, eu registrei todas as etapas em vídeo, com o compromisso de devolver o material à aldeia.

Passado o trauma da extinção física, o espectro que ronda a aldeia é o de "perda da cultura". A preocupação em "guardar a cultura para não perder" por meio do vídeo, registrada por Müller em 2000, cresceu ainda mais ao longo dos anos, o que fica evidente nas queixas recentes dos velhos em relação à falta de interesse dos mais jovens na participação nos rituais, no trabalho dos roçados, na fabricação de objetos trançados e cerâmicos, dentre outros. Diferentemente das velhas gerações, as crianças e jovens de hoje cresceram em contexto marcado por intenso contato com os brancos, deparando-se com novas realidades e tendo que 
construir sua identidade a partir dessa situação ${ }^{49}$.

O discurso de "guardar a cultura" via audiovisual se enuncia no registro do diálogo interétnico em que possuir ou perder "cultura" são atributos de um processo dinâmico, como revela a fala de uma índia que, após receber a remuneração do seu marido pelo trabalho de piloto de voadeira, disse que estava indo para a cidade para "perder a cultura" nos bailes de música brega no porto da cidade de Altamira, Pará. A índia é uma exímia conhecedora dos cantos femininos dos rituais xamanísticos, e fora esposa mais nova de um dos xamãs de maior prestígio, Pinasiré, falecido ainda nos anos 1980.

De fato, de acordo com os termos asuriní para se referirem a televisão, gravador, DVD e CD, o audiovisual possui a capacidade de "guardar", "conservar" e "preservar" cantos e seqüências rituais, conhecimentos aos quais os índios estão se referindo ao empregar o termo "cultura". Provavelmente os Asuriní não diriam que "cultura" é ynga, mas o audiovisual guardando o ynga (voz e "sombra" enquanto imagem em movimento) estaria "conservando a cultura".

Contudo, a contradição de "guardar" por imagens e sons é que, embora se busque salvaguardar a cultura em seu sentido antropológico (esse esquema que organiza a percepção do mundo e a comunicação entre as pessoas e que produz saberes e modos de fazer relacionados aos cantos, rituais, confecção de cultura material, dentre outros $)^{50}$, o discurso dos índios termina por produzir a "cultura" de modo objetivado. A maneira pela qual os materiais circulam na aldeia em 2007 nos mostra que as potencialidades do "registro da cultura", de interesse dos índios, não se relaciona com a transmissão dos conhecimentos - como imaginado pelas diretrizes do projeto do patrimônio formatado e implementado nos Asuriní em 2007 - através de exibições de imagens ou sessões de escuta coletivas, ou mesmo como conteúdo da escola indígena ${ }^{51}$. A circulação do material nos coloca outras questões para além da documentação a serviço da transmissão da

49 Este contexto também é mencionado por Silva (2005, p.26).

$50 \mathrm{Ou}$ "aquela 'rede invisível na qual estamos suspensos'" para usar as palavras de Carneiro da Cunha, 2009, p. 373. Para uma análise do conceito de cultura em sentido antropológico $x$ "cultura", ver a mesma obra, p. 354-358.

510 que se deveu, em grande medida, ao fato de não haver na aldeia durante este período, profissionais ligados à educação capacitados para o trabalho com estes materiais. 
"cultura". O que está em jogo aqui, essencialmente, é que passamos do registro da cultura para o registro da "cultura" (com aspas) e, embora vídeos, fotografias e CDs de áudio sejam a própria metáfora da cultura (em sentido antropológico), é de "cultura" de um modo objetivado (literalmente "cultura" tornada objeto) operada no universo discursivo interétnico de que estamos falando. A partir da definição da "cultura" (com aspas) como a apropriação nativa do termo operada no regime discursivo interétnico, Carneiro da Cunha vai dizer que, de posse de uma "cultura" seus possuidores são obrigados a "exibi-la diante do mundo" (2009, p. 313), abrindo um canal dialógico que possibilita estabelecer uma relação performatizada - mostrar a "cultura" para o outro.

Mas há, ainda, outras contradições em "guardar a cultura" por imagens e sons. Uma delas consiste no fato de que, embora entre os Asuriní se produza uma grande quantidade de material de registro de rituais e seqüências de saberes diversos, eles não se mostram nem um pouco preocupados com o armazenamento destes suportes; fitas, CDs, DVDs e fotografias se deterioram rapidamente na aldeia. Fenômeno semelhante acontece entre os Kayapó Mebêngôkre descritos por Madi Dias (2011), que buscam "guardar a cultura" por intermédio das extensas filmagens que eles mesmos realizam, e, no entanto, o material filmado se torna rapidamente inutilizável. E se a "cultura" não fica guardada pela rápida deterioração do suporte, como pensar a demanda contínua de registro?

A ênfase, aqui, recai mais sobre o processo de produção do registro do que sobre os produtos por ele gerados. No ritual Apykwara, os Asuriní fizeram questão que eu filmasse absolutamente todos os ritos ao longo de dois meses, o que resultou em mais de 40 horas de vídeo, e, cerca de um ano depois, quando exibi parte do material bruto, poucos se interessaram. Novamente o paralelo com o caso kayapó nos ajuda a pensar a produção incessante de imagens. Madi Dias (Op. cit., p. 306) afirma:

[...] penso ser interessante compreender as imagens como estímulos à criação de contextos rituais e culturais que procuram eliminar as contradições, guardando a cultura em sua sincronia, na medida em que se proliferam as práticas culturais para a filmagem. 0 vídeo faz as pessoas 
fazerem as coisas, em uma espécie de devir imagético (Gonçalves \& Head, 2009) que produz consciência e reflexividade, destacando as práticas de um fluxo vivido e as objetivando enquanto representações (grifos do autor).

O audiovisual, entre os Asuriní, faz as coisas acontecerem e se torna uma ferramenta para "guardar" os conhecimentos e auxiliar na transmissão dos saberes sobretudo na medida em que provoca situações em que esses conhecimentos são colocados em circulação. E não é de se estranhar que justamente na realização de rituais xamanísticos essas imagens audiovisuais façam a mediação entre índios e brancos. Como bem observa Cesarino (2012), o xamanismo se especializou na captura e recriação de novas formas (do seu ponto de vista consideradas como antigas e já conhecidas), propondo suas próprias soluções face aos modos de transmissão de conhecimentos não ameríndios, como nos casos de processos de escolarização e de educação universitária, da expansão de redes neoxamânicas e das próprias redefinições da "cultura" (Cf. Carneiro da Cunha, 2009).

$\underline{0 \text { audiovisual e o xamanismo }}$

Aproximações entre o audiovisual e o xamanismo foram sugeridas pelos Asuriní pela primeira vez em 1997, na ocasião da exibição do filme A guerra do $f o g o^{52}$, que trata do embate de duas tribos de homens primitivos, uma delas de homens-macaco. Durante a sessão, um dos índios relacionou o filme que acabara de ver às narrativas xamânicas; segundo Müller (2000, p. 185), ele comentou que o filme faz o mesmo que o xamã quando conta suas viagens cósmicas: faz existir como realidade acontecimentos e lugares só conhecidos por eles. Assim, os relatos do xamã e a imagem em movimento seriam narrativas que fariam existir realidades virtuais, que se encontram no espaço e no tempo mítico. Segundo explicação dada pela antropóloga na ocasião da exibição, os homens-macaco seriam os "antepassados dos brancos", ao que os índios concluem que o filme $A$

${ }^{52}$ A Guerra do Fogo (La Guerre du Feu). Direção: Jean-Jacques Annaud. EUA: Twentieth Century Fox Film Corp, 1981, 100 min, cor. 
guerra do fogo fazia existir o passado mítico do homem branco (Müller, 2000, p. 184-185).

Quando levei para a aldeia a extensa documentação em vídeo do ritual xamanístico Apykwara, realizado em 2007, além do desinteresse dos Asuriní pelas imagens de uma maneira geral, como já mencionei, chamou atenção a indiferença do xamã Mure'yra, protagonista do ritual, pelas filmagens. Ele me chamou de canto dizendo querer ver "javara", referindo-se ao filme realizado por Müller e Valadão em 1997. Em Morayngava, as autoras utilizaram recursos de sobreposição de imagens e efeitos especiais para marcar a passagem de um domínio do cosmo para outro e, assim, acompanhar a produção de imagens dos xamãs nas narrativas de suas viagens a outros mundos. No filme, tratava-se do espírito Tivá, traduzido pelos Asuriní como javara (onça), espírito xamã primordial, de acordo com a classificação dos seres de Müller (1993, p. 190), que, segundo descrições asuriní, é um misto de onça com pássaro. 0 xamã, então, pediu que eu realizasse uma montagem nos mesmos moldes, tematizando sua viagem ao mundo de um outro espírito - desta vez, o espírito-animal Tajaho (porco-do-mato) ${ }^{53}$.

O comentário do índio durante a exibição de A guerra do fogo e o pedido do xamã para que eu realizasse a montagem de um filme sobre o espírito Tajaho despertaram o desejo de investigar mais profundamente as relações sugeridas pelos Asuriní entre narrativas míticas - tematizando viagens ao mundo dos espíritos - e as potencialidades do meio audiovisual como forma expressiva. Instigava-me saber como imagens verbais criadas com o relato do xamã e imagens audiovisuais "fariam existir" universos virtuais, e quais as semelhanças e as diferenças da produção imagética no contexto do xamanismo e do audiovisual.

Imagens dos sonhos dos xamãs em suas viagens ao mundo dos espíritos se tornam acessíveis nas suas performances narrativas durante um rito específico dos rituais xamanísticos maraká. A experiência da viagem ao mundo sobrenatural é vivida individualmente e contada em primeira pessoa durante o

\footnotetext{
53 Realizar esta montagem era uma proposta contida nas primeiras formulações do projeto de pesquisa de doutorado, que acabou indo por outros caminhos. Mas a ideia do xamã é boa e, de forma alguma, um projeto adiado.
} 
rito petymojap (petym = charuto; omojap = acender). Müller (1993, p. 185), afirma que nessas reuniões os xamãs trocam entre si experiências individuais de suas viagens às diferentes zonas cósmicas, conferindo, reafirmando e recriando formas, processos e conteúdos da cosmologia.

Entre os Yanomami, o modo fundamental de "ser-imagem" (ancestrais "humanimais" e/ou constituintes da pessoa), que dá acesso ao "ver xamânico" do sonho e do transe, constitui-se como o centro de gravidade do pensamento ontológico e cosmológico deste povo ${ }^{54}$. Embora sejam imagens do sonho, Albert chama atenção para o fato de que não podemos associá-las às "imagens mentais" ("visões interiores"). As visões do xamã são, antes de tudo, percepções diretas de uma realidade externa absolutamente tangível (o "ver" aqui é autenticamente "conhecer"). Além disso, elas são tornadas visíveis para as pessoas comuns que assistem às sessões nas quais os xamãs se assimilam, durante o transe, aos seresimagens mitológicos que "fazem descer" e "fazem dançar". Através dos cantos e coreografias, eles mesmos se tornam os "corpos condutores" dos ancestrais humanimais ${ }^{55}$.

As "visões" dos xamãs Asuriní seriam tornadas visíveis para o público de "pessoas comuns" nas sessões de petymojap e, diferentemente do caso yanomami, seriam colocadas em circulação por meio de narrativas orais. Aqui, imagens da experiência do sonho do xamã, em que seu duplo viaja ao mundo dos espíritos e experimenta a convivência com seres do cosmo, são passadas a um outro código, o verbal, das imagens verbais tais como metáforas e descrições. 0 que os Asuriní colocaram em relação são as imagens mentais que passam a existir na cabeça do ouvinte das sessões do petymojap com as imagens do que poderíamos chamar de "código audiovisual". Até onde pude investigar, a qualidade comum aos diferentes códigos em que operam imagens é que elas

\footnotetext{
54 Potencialidades do audiovisual e do xamanismo yanomami foram colocadas em relação no filme Xapiri, que adota uma linguagem experimental para tornar visível e sensível para públicos de culturas diferentes o modo segundo o qual os xamãs "incorporam" os espíritos. O filme foi dirigido pelo coletivo composto por Leandro Lima, Gisela Motta, Laymert Garcia dos Santos, Stella Senra e Bruce Albert. São Paulo: Cinemateca Brasileira, Instituto Socioambiental, Laboratório de Cultura e Tecnologia em Rede/i21, Hutukara Associação Yanomami, 54 min, 2012, cor.

55 Fonte: "Images, traces et 'hyper images" : impromptu d'ethnographie noctambule". Disponível em: http://www.ctrlab.inf.br/reflexao.html. Acesso em setembro de 2015.
} 
"fazem existir", e isso faz bastante sentido, a partir de tudo que viemos falando até aqui.

Uma das formas possíveis de pensar as relações entre narrativas míticas e fílmicas, sugeridas pelos Asuriní, foi tomá-las como momentos de visualização do invisível. Assim, tanto a plateia da performance do xamã quanto os espectadores do filme são convidados a penetrar num universo de imagens de um "mundo recriado" momentaneamente. Diversos trabalhos acerca de sociedades ameríndias abordam as experiências de visualização do "sobrenatural". Para os Wauja (ver Barcelos Neto, 2008), a visão manifesta-se na produção simbólica de um mundo invisível (agentes patogênicos, alteridades extra-humanas) e na produção de sua visualidade concreta (desenhos, artefatos, pinturas, adornos corporais, máscaras e flautas). Ver o invisível é atividade de alto valor estético, acessível àqueles que detêm habilidades especiais. Assim, para este povo, o xamanismo encontra-se no centro da produção artística. Sonhos, transes, mortes, doenças graves são contextos de visualização do "sobrenatural".

Na região do Alto Ucayali, no leste do Peru, a população local faz uma analogia entre o cinema e o alucinógeno ayahuasca, que eles denominam o "cinema da floresta". As relações entre as experiências visuais do cinema e do ayahuasca são diversas: além de a droga ser tomada no escuro, "[a]s alucinações hacen ver, 'fazem ver': tanto as origens da doença, como objetos de feitiçaria brilhando no corpo de um doente, países distantes, parentes mortos ou distantes etc." (Gow, 1995, p. 44, grifos do autor). Dessa maneira, "[o] ayahuasca é uma planta da floresta que permite o acesso à verdadeira identidade visual da floresta, como o cinema, um produto estrangeiro, permite acesso visual a países distantes, ao 'lado de fora'” (Op. cit., p. 47, grifo do autor).

Ver o que nem todos veem é atividade exclusiva aos xamãs Asuriní. Ouvi muitas vezes, ao fim de relatos míticos contando histórias de espíritos, a frase "pajé uesak', quer dizer, o que eles contam como história, o xamã vê e experimenta enquanto realidade. Filmes e narrativas xamânicas "fazem ver", novamente, antes de tudo eles fazem, agem sobre o mundo.

0 audiovisual age, de fato, e nem sempre de maneira positiva. Antes de fechar esta reflexão, retomo uma passagem narrada por Müller (2000) em que 
ela conta sobre a presença da câmera filmadora num ritual de iniciação de um xamã. Na verdade, o ritual é realizado para ser filmado, e, conforme já abordamos, o resultado das imagens pode ser visto no filme Morayngava. 0 ritual trouxe o espírito Arapoá (veado) para que o neófito, o índio Takamuin, passasse pela experiência de ter introduzido em seu corpo o $k a^{\prime} a ́$, substância transmitida pelos espíritos aos xamãs em transe e destes ao neófito. Para que o processo se realize, o iniciante deve se encontrar em estado de transe, chamado yngaiva, que os Asuriní traduziram por "tremor" (Müller, 2000, p. 182).

Após alguns dias depois de iniciado o ritual, Takamuin deu seu depoimento sobre a experiência a que se submetera nos seguintes termos:

Se continuar tremendo, caindo, levantando, hoje à noite quem sabe eu possa pegar. Eu ainda não estou muito tonto, mole, ninguém ajuda, só o Murey'ra. Sonhei que cheguei num lugar onde se põe ka'á no cigarro. $\mathrm{Na}$ boca da noite outro pajé vai fazer festa. Quando tremer demais, aí vem o $k a$ 'á que entra no corpo. Quando está doente é mais fácil de pegar, quando não está, sem doença, é mais difícil virar pajé. 0 pajé tem de continuar, tremer, tremer, tremer até cair, pegar, morrer. Vamos ver se hoje à noite eu pego, estou tremendo, mas ainda é pouco. Antigamente tinha muito pajé para ajudar virar pajé. Morreram quase todos os pajés (Op.cit., Ibid.).

O ritual segue seu curso e os xamãs desistem de iniciar Takamuin. Anos depois, quando perguntei para ele por que sua iniciação não fora completada, ele me respondeu que não tinha sonhos com "coisas dos Asuriní”, suas viagens aos mundos dos espíritos eram repletas de elementos akaraí tais como caminhões, abertura de um ventre em uma operação cirúrgica e o sobrevoo de um helicóptero ${ }^{56}$.

Müller apresenta uma outra interpretação para o insucesso da iniciação de Takamuin ao apontar para a presença da câmera durante o ritual, ainda que a filmagem tenha sido proposta pelos índios. Para atingir o objetivo de filmar a iniciação, os Asuriní "[...] tiveram de reelaborar concepções e colocar em risco a

560 relato destas viagens cósmicas realizadas por Takamuin, assim como os relatos de Mure'yra, também aparecem no filme Morayngava através do recurso da sobreposição de imagens. 
própria tentativa de introduzir o ka'á no corpo de Takamuin ao permitirem que, para filmar o momento em que isto ocorre, uma iluminação perigosa ameaçasse seu êxito e invertesse drasticamente uma das condições mais essenciais ao transe dos xamãs, o lusco-fusco do ambiente" (Müller, 2000, p. 183). Em mais de vinte anos acompanhando diversos rituais xamanísticos, Müller afirma jamais ter tido a presença de uma luz razoável durante este momento. 0 gravador de som que usou certa vez para registrar a iniciação de um xamã foi responsabilizado pelo fracasso de não se conseguir introduzir o $k a^{\prime a ́}$ no corpo do iniciando. Na ocasião da filmagem da iniciação de Takamuin, a equipe dispôs, num primeiro momento, de toda a luz necessária. Porém, alguns dias depois, as antropólogas foram advertidas a não mais utilizar luz artificial para registrar o transe dos xamãs.

Mais uma vez o xamanismo está no centro da relação entre os Asuriní e os brancos, que é mediada por imagens técnicas audiovisuais. De forma nociva, a luz artificial que a filmagem requerida pelos próprios índios exige interferiu na iniciação. Ao mesmo tempo, e não é nada espantoso que justamente o xamã Asuriní, tradutor por ofício e vocação, goste da montagem fílmica e desafie os antropólogos a produzir narrativas audiovisuais que ecoem as intenções das suas narrativas xamânicas, vividas em primeira pessoa quando acessa universos míticos que só ele conhece. 0 xamã, como um tradutor, trabalha no sentido de transpor contradições em códigos diferentes, "[...] como se, de tanto traduzi-las, fosse possível resolvê-las, a dolorosa sensibilidade do xamã às dificuldades e armadilhas dessas passagens entre códigos que jamais são inteiramente equivalentes [...]" (Carneiro da Cunha, 1998, p. 13-14.). 


\section{CAPÍTULO II}
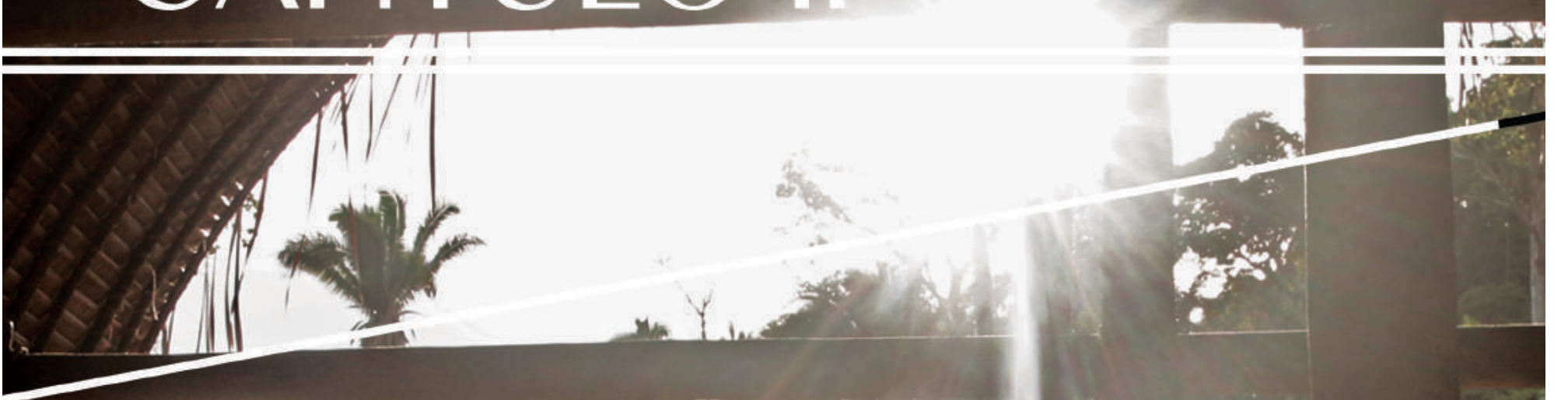

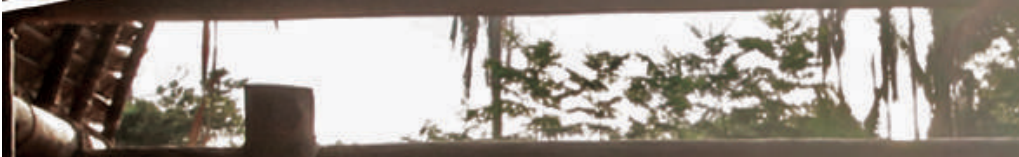
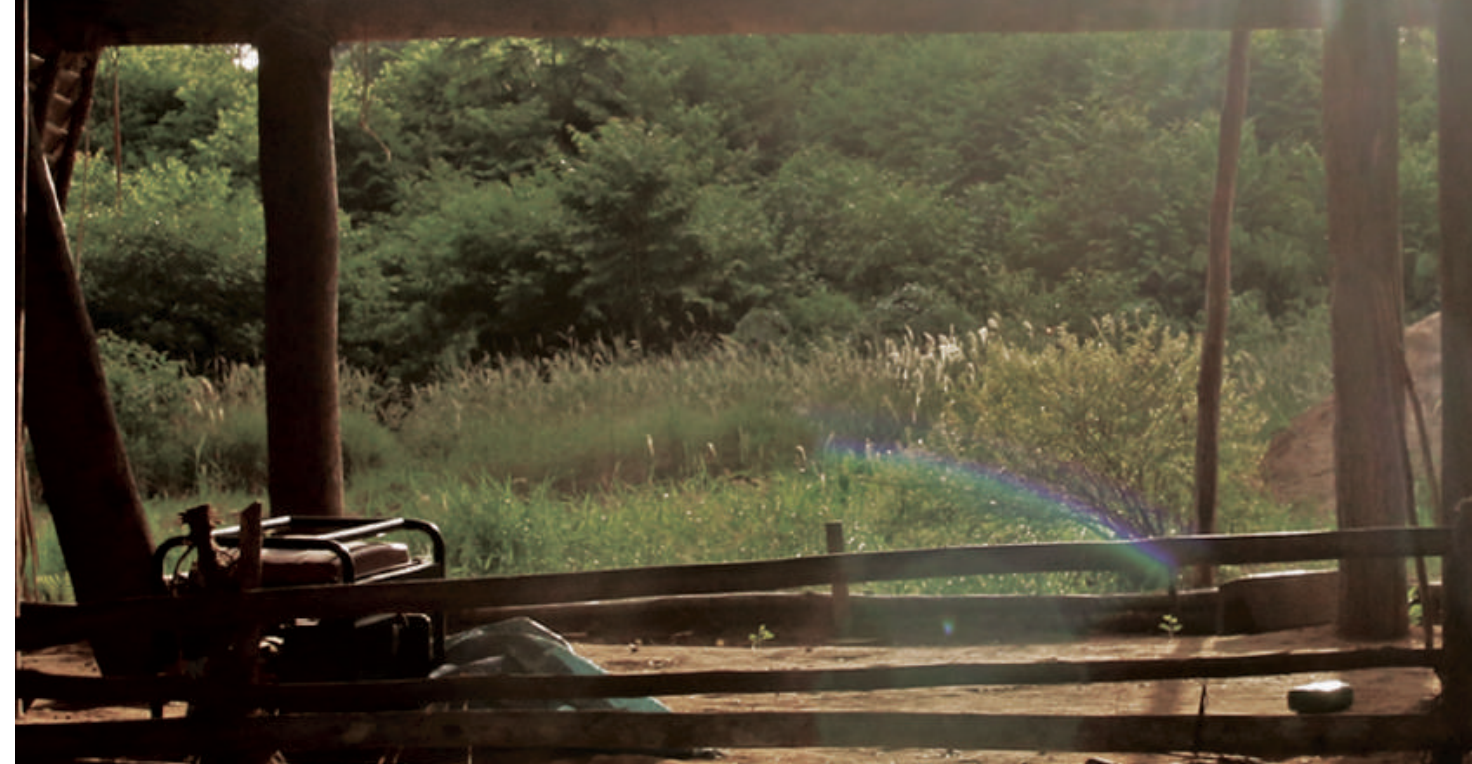


\section{CAPÍTULO 2}

\section{A FOTOGRAFIA COMO OBJETO PATOGÊNICO}

No início dos anos 1970, os irmãos Anton e Karl Lukesch, missionários católicos austríacos ligados à Prelazia do Xingu, foram contratados pela empresa Meridional Consórcio United States Steel Curd - que estava interessada na extensão da província ferrífera dos Carajás até a margem direita do Xingu - para realizar o programa de "pacificação" dos Asuriní. A necessidade de contatar grupos indígenas da região se ampliou com o avanço da exploração econômica no médio Xingu, por meio de grandes projetos arquitetados principalmente pelo Estado, tais como mineração, agropecuária e, em especial, a construção da rodovia Transamazônica (BR-230).

A versão asuriní do primeiro contato conta que: “Quando o padre Antônio encontrou com eles tirou fotografia e aí homem morreu, não agüentou" (Müller, 2000, p. 184). A reprodução da imagem dos seres humanos pela fotografia foi considerada uma ameaça à vida da aldeia, e sua manipulação, a causa de muitas doenças. A câmera fotográfica suga o ynga (princípio vital) da pessoa fotografada ao reproduzir sua imagem, ayngava (Op. cit., p. 183).

Em meados de outubro de 2012, retornei aos Asuriní para iniciar a pesquisa de campo para o doutorado e, nesta ocasião, obtive a confirmação dos relatos acerca da patogenia da fotografia no contato registrados por Müller na década de 1990. Takamuin me disse que, quando "o padre Antônio tirou fotografia, pegou o ynga e o ynga ficou dentro da máquina". Apebu também reiterou a informação ao afirmar que "a primeira foto que padre pegou tirou o ynga, aí homem morreu". Ouvi de Marakauá e Boaiva, velhos de mais de 60 anos, 
comentários semelhantes que apontavam para o perigo da fotografia no primeiro encontro com o homem branco.

Como já se abordou no capítulo 1 desta tese, os Asuriní traduzem o ynga como sombra, substância vital que anima o corpo, princípio vital visualizado mas sem matéria, e que se manifesta por meio da voz, pulsação e batidas do coração. Ayngava, o modo como se referem às fotografias, pode ser traduzido por imitação e imagem. Fotografias de pessoas são sempre referidas pelo termo ayngava, precedido de seu possuidor.

A ideia de que ayngava contém ynga foi trabalhada por Müller (1993, p. 244). A autora argumenta que, apesar de se tratar de uma semelhança apenas morfofonêmica entre ynga e ayngava, pois designam coisas diferentes, o significado de uma constitui (é parte de) o significado da outra. Seguindo a sugestão de Müller, veremos que as relações que podem ser estabelecidas a partir da ideia de que ayngava (imagem) contem ynga (princípio vital) são um passo fundamental para a compreensão dos depoimentos dos Asuriní acerca da ação patogênica da fotografia.

A busca pelo entendimento do que os Asuriní estavam falando me levou à formulação de algumas questões. Tratar-se-ia de compreender de que maneira a fotografia atua de forma patogênica, que relações estabelece com os corpos e quais são os princípios da sua eficácia sobre a pessoa retratada. Para além da elaboração das perguntas, seria preciso ajustá-las a um quadro teóricometodológico que me permitisse levar em conta as capacidades da fotografia em "pegar" ou "sugar" o ynga da pessoa. Portanto, a construção da perspectiva da fotografia enquanto objeto com agência social (Gell, 1998) veio ao encontro do que estava sendo expresso nos relatos dos índios. Para os Asuriní, a questão que a fotografia no contato coloca diz respeito ao que ela $f a z$ ou é capaz de fazer. Ao indicar os modos de agir das imagens fotográficas os Asuriní estavam chamando atenção para o fato de que elas deveriam ser tratadas mais como sujeitos e menos a partir de sua condição de símbolo ${ }^{57}$.

${ }^{57}$ Ver Barcelos Neto (2008, p. 31-32), que formula questões semelhantes a partir da investigação do problema social e cultural que os apapaatai, seres prototípicos da 
Em virtude da relevância das questões levantadas até aqui, refaço, neste capítulo, o percurso que a pesquisa inicialmente realizou - no que diz respeito à elaboração da abordagem a partir do problema de campo - como forma de restituir o caráter processual deste trabalho. Além disso, como se verá no desenrolar da tese, a perspectiva de entender a agência das imagens fotográficas não se encerra apenas na reflexão do primeiro contato dos índios com a câmera dos brancos, mas perpassa todo o trabalho. Espero, desta forma, que o leitor possa compreender o projeto, aparentemente estranho e insistente, de perseguir as fotografias e suas relações com os Asuriní, do contato aos dias atuais.

Da formulação inicial de questões da pesquisa surgem algumas derivações. A primeira delas, ainda no âmbito conceitual, é reconhecer algumas possíveis afinidades entre fotografia e magia para, em seguida, dar lugar à etnografia asuriní que nos provê de exemplos em que são colocados em prática relações entre princípio e substância vital, objetos e pessoas, e que nos permitem iluminar a compreensão da fotografia, esta imagem objeto que carrega ynga. A fotografia não age por si de maneira deletéria, sua agência está subordinada à intenção de seus produtores, os brancos, que são, por este e por outros motivos, considerados inimigos e até feiticeiros, potencialmente causadores de males.

Até aqui, o esforço consiste em apresentar algumas questões colocadas pela fotografia no contato, de forma a circunscrever a afirmação asuriní - que neste trabalho é elevada ao estatuto de máxima: "a fotografia suga o ynga ao reproduzir sua imagem, ayngava, causando mortes e adoecimentos" 58. As reflexões da segunda parte do capítulo são de caráter etnográfico e versam sobre o domínio da morte. A partir da ideia de que a fotografia age sobre a pessoa retratada, subtraindo seu ynga, exploraremos alguns processos envolvidos na desintegração da pessoa após sua morte, com ênfase especial ao espectro anhynga que é liberado nesta ocasião. Por fim, chegamos à tavyve, habitação que abriga a sepultura dos mortos, elo que articula vida e morte, e em torno das quais os Asuriní dos dias de hoje dedicam grande esforço para manter erguidas e em

alteridade, impõem. 0 autor afirma que o que os apapaatai são capazes de fazer, ou o que se é capaz de fazer para e com eles, são questões relevantes para a ontologia wauja. ${ }^{58}$ Note-se que o que chamo de "máxima asuriní" já é uma elaboração do discurso indígena em uma formulação antropológica que relaciona ayngava e ynga. 
bom estado nas aldeias. Algumas fotografias da recém-construída tavyve da aldeia Ita'aka são apresentadas a fim de revelar a importância das casas comunais na vida asuriní, como forma privilegiada e inflexível de relacionamento com os mortos, e que persiste no contexto atual, marcado por profundas transformações decorrentes do intenso contato com os brancos.

\subsection{Agência, pessoa e imagem}

A relação entre ayngava (imitação, imagem,) e ynga (princípio vital) está na base da ideia da agência patogênica da fotografia, fundamentada no xamanismo como ponto de vista privilegiado da sociedade asuriní e da figura do xamã como organizador e catalisador dessa visão. Refletir sobre os efeitos da reprodução da imagem de uma pessoa significa pensar a fotografia a partir de conceitos nativos referentes ao domínio da imagem que estão associados a processos de consubstanciação ${ }^{59}$ do princípio vital entre pessoas, espíritos e objetos.

A eficácia ou o poder da imagem fotográfica entre os Asuriní pode ser pensada em termos da teoria da agência social de Gell (1998), que propõe que se trate "objetos como pessoas", devido à atribuição de intenção e consciência aos objetos não viventes. Lagrou (2007) afirma que a proposta de Gell de aproximar artefatos e pessoas parece menos estranha ao esforço teórico da antropologia ao se pensar que esta se debruça, desde seus primórdios, sobre discussões acerca do animismo - a atribuição de sensibilidade às coisas inanimadas, plantas, animais etc. De Taylor até os dias de hoje, portanto, interessou-se a disciplina pela reflexão sobre as relações peculiares entre pessoas e coisas que de alguma maneira se parecem ou funcionam como pessoas (Lagrou, 2003, p. 101).

Gell teve um papel decisivo no debate da antropologia da arte, e deu renovação teórica aos estudos de objetos pensados por ele como extensões de pessoas e com papel crucial nas interações sociais. Em seu livro póstumo Art and

\footnotetext{
${ }^{59}$ Entende-se por consubstanciação o processo por meio do qual seres ou objetos compartilham a mesma substância, no caso, o ynga partilhado entre humanos e espíritos no ritual e entre uma pessoa e a sua imagem fotográfica. No dicionário Michaelis on line, consubstanciação é definida como "União de dois ou mais corpos em uma só substância" e "Presença de Cristo na Eucaristia". Müller (1993, p. 175) utiliza o termo para se referir ao processo pelo qual dois seres cosmicamente diferentes compartilham a mesma substância, num dado momento do ritual.
} 
Agency (1998), ele se recusa a tratar a arte como linguagem e, para isso, descarta a aliança da antropologia social com disciplinas relacionadas à estética, como a semiótica e a hermenêutica, no estudo das obras de arte. Para ele, a antropologia, disciplina alheia aos julgamentos de valores, não poderia trabalhar com juízos de valores estéticos com pretensões universalistas.

A defesa de Gell e premissa de sua teoria baseiam-se na ideia de que a natureza do objeto de arte é uma função da matriz sociorrelacional na qual está inserido, o que quer dizer que o objeto não possui natureza intrínseca, independente do contexto relacional. Do ponto de vista da antropologia social, qualquer coisa pode ser pensada como objeto de arte, incluindo-se aí pessoas vivas. 0 autor define a antropologia da arte como "[...] o estudo teórico das 'relações sociais na vizinhança de objetos que medeiam agência social'", que se fundem sem problemas com a antropologia social das pessoas e seus corpos (Gell, 1998, p. 7).

Lagrou (2007) afirma que pensar sobre arte para os ameríndios significa pensar sobre as noções de pessoa e corpo. Tomar objetos e artefatos "como se fossem pessoas" enfatizando suas qualidades de agência sugere-nos pensar as relações que podem ser estabelecidas entre corpo e produção de imagens e entre corpo e artefato e/ou objeto. Em A fluidez da forma (2007), Lagrou trata das relações entre imagens, corpos e pessoas, ao abordar o poder e a agência de diferentes tipos de imagens (gráficas, poéticas, materiais e corporais) em dar forma às ideias centrais dos Kaxinawa sobre as pessoas (humanas e não humanas) e suas relações com o mundo envolvente.

A imagem é parte da pessoa e, como uma representação que partilha a qualidade (ou "essência") do representado, estabelece uma relação metonímica com a pessoa e é constitutiva do ser (Lagrou, 2007), o que sugere uma estreita relação entre imagem e noção de pessoa (Mauss, 2003). Imagem pode ser pensada, também, em termos de multiplicação e distribuição da pessoa por meio da fotografia, a partir da ideia de pessoa distribuída (distributed person) de Gell (1998), noção construída com o material melanésio, mas que rende reflexões se trazida para o contexto ameríndio. 
Pensar fotografias como objetos significa dar ênfase a sua materialidade física. Para Elizabeth Edwards e Janice Hart (2004), fotografias são duplamente imagens e objetos físicos que existem no tempo e no espaço, na experiência social e cultural; apresentam volume, opacidade, tatilidade e uma presença física no mundo (Batchen apud Edwards e Hart, 2004, p. 1). No livro Photographs objects histories, coletânea de estudos que trata a fotografia com ênfase em sua materialidade, os autores trabalham com a ideia de que a materialidade da imagem fotográfica e a imagem por si mesma são indissociáveis, e tratam de observar as influências dos atributos físicos da fotografia na projeção da informação visual.

A preocupação com a materialidade nos estudos sobre fotografia é decorrência de uma influência metodológica que Edwards e Hart (2004) chamam de "material turn", que atinge campos do conhecimento como a antropologia, a história da arte e os estudos culturais ${ }^{60}$, no qual Gell teve importante papel. Portanto, a mudança de ênfase no estudo dos objetos, que passam a ser compreendidos em uma rede de sociabilidade e não a partir de um enfoque lingüístico ou estético, estende-se também para os estudos da fotografia.

A abordagem da fotografia como objeto inserido no campo das ações sociais sugere que se pense, com Gell, na maneira como ela atua de forma patogênica e que relações estabelece com a pessoa retratada. Sustento a hipótese de que a agência da fotografia entre os Asuriní está ancorada na indissolubilidade entre imagem e representação plástica ou, de outra forma, entre a materialidade da fotografia e a informação visual que ela apresenta. Para além disso, creio que é a materialidade da imagem fotográfica que a investe de poder para atuar sobre a pessoa, porque, assim como corpos de pessoas, fotografias possuem forma material de seres humanos, carregam ynga. Embora, segundo os Asuriní, os processos de captura de ynga da pessoa pela fotografia,

60 Edwards e Hart citam autores como Miller (1987), Banks e Morphy (1997) e Gell (1998) na antropologia, Baxandall (1988) na história da arte. Estes autores têm em comum tratar os objetos, incluindo fotografias, em sua existência mundana social, pensados, não apenas como cenários de ações humanas, mas integrados às ações sociais. A mudança de enfoque na abordagem dos objetos também se faz sentir na produção da arte contemporânea, em artistas como Christian Boltanski, Joachim Schmid e Mohini Chandra, que fazem novos usos da fotografia; para mais informações sobre esse tema, ver Rouillé (2009). 
pelo vídeo e pela televisão sejam análogos ${ }^{61}$, a agência da imagem fotográfica parece ser mais perigosa por sua representação plástica.

Silvia Pellegrino, em sua tese de doutorado "Imagens e Substâncias como Vínculos de Pertencimento: as experiências Wajãpi e Yanomami”, defendida no Departamento de Antropologia Social da USP em 2008, aborda as denúncias e angústias que os Wajãpi manifestam com relação à falta de controle sobre a veiculação de suas imagens fotográficas, e as queixas dos Yanomami em relação à coleta e conservação de sangue para pesquisas biotecnológicas. Imagens e sangue são abordados de forma comparativa, como constitutivos de vínculos de pertencimento de seus povos em relação a sua memória e saberes. Embora a autora concentre sua atenção nas controvérsias dos diferentes contextos que chama de redes-imagem wajãpi versus redes-patrimônio e biorredes yanomami versus biorredes genômicas, a tese apresenta dados etnográficos interessantes que possibilitam estabelecer relações entre imagem, pessoa e substância.

Citando Gallois e Carelli (1992), Pellegrino afirma que os Wajãpi dizem que a TV "traz a pessoa”, o que significa que eles estão se referindo não apenas às manifestações imateriais presentes no retrato (ra'anga) e no discurso transmitido pela TV, mas à parte substancial do princípio vital (-ã), que está contido "dentro" da imagem de qualquer pessoa. Os Wajãpi estabelecem uma diferença entre duas formas de representação: a cópia (desenho, símbolo etc.), que não carrega elementos vitais do ser representado, e o retrato propriamente dito, que representa a pessoa em sua totalidade. Fotografia e imagem de vídeo constituem uma reprodução completa, possibilitando apropriação física.

Assim como entre os Asuriní, existe uma relação de continuidade entre a imagem e a pessoa fotografada, e isso se dá porque sua substância vital (ã em wajãpi e ynga em asuriní) também impregna a fotografia. No caso wajãpi, existe uma tensão entre a vontade de divulgação das fotografias e o cuidado em relação ao deslocamento e à fragmentação do princípio vital decorrente da circulação das imagens. 0 distanciamento entre pessoa e imagem promove, portanto, a separação do princípio vital do corpo do fotografado, o que pode ter um efeito

\footnotetext{
${ }^{61}$ Entre os Wajãpi, segundo Pellegrino (2008, p. 69) as fotografias (digitais) que estão no computador são menos perigosas do que as impressas, pela dificuldade em retirá-las do monitor.
} 
extremamente danoso, já que a ação sobre a fotografia recai também na pessoa retratada. Informada pela etnografia de Gallois (1988), Pellegrino identifica que o que está em jogo são relações de substâncias inseridas no complexo de agressões xamânicas praticadas entre grupos de conflito que continuamente se entrecruzam:

As fotos, portanto, inserem-se como uma forma de aproximação substancial entre inimigos pela figura do xamã, inclusive sob a forma de trajetória para a ação agressiva: um caminho para se chegar até a vítima. A ideia de rastro produzida pelas fotografias insere as imagens no complexo das feitiçarias de rastro operante entre os Wajãpi e configura igualmente um aspecto importante que dá forma a este princípio de contigüidade [...] (Pellegrino, 2008, p. 59).

Depoimentos wajãpi indicam que o perigo maior não reside na possibilidade de a foto ser "vista" mas na eventualidade de ser "pêga" e manuseada, o que pode apontar para seu uso na feitiçaria de rastro. 0 índio Aikyry afirma: "A pessoa pega a foto e coloca alguma coisa que faz mal, bem enrolado (...) aí vai jogar junto com pedra no fundo do rio e você vai sentir, sofrer dor de cabeça, começar a sonhar com coisa feia, e ficar doente e ninguém descobre e morre de repente. Aí quem cura isso só pajé (...)" (Pellegrino, 2008, p. 59). Suponho que semelhante apreensão existiu entre os Asuriní, embora nunca tenham formulado em contornos tão claros como a forma com que aparece no relato transcrito. 0 entendimento, compartilhado com os Wajãpi, de que fotografias carregam o princípio ou substância vital, abrem precedentes para que ela possa ser utilizada em ações mágicas.

\subsection{A magia da fotografia}

A fascinação de alguns Asuriní por meus equipamentos de produção de imagem, fossem câmeras filmadoras ou fotográficas, sempre foi algo notável. Recordo-me de um dia em que dediquei uma tarde a ensinar o xamã Mure'yra, de 85 anos, a operar uma câmera filmadora digital. Ele filmava e em seguida pedia para assistir o que acabara de registrar, abrindo um sorriso a cada vez que via as 
imagens no pequeno visor, como se a câmera fosse investida de capacidades mágicas. $\mathrm{O}$ encanto dele alimentou ainda mais meu encanto pelo fascínio deles a estes equipamentos.

No início da pesquisa de campo, perguntei a Apebu como a máquina de tirar fotografias "pegou" o ynga das pessoas retratadas no contato. Ele me devolveu a questão: "Pergunta para quem fez a máquina". 0 índio não colocava em pauta o fato de a fotografia ter ou não subtraído o ynga do fotografado, isso era dado. Ele ia além ao apontar para o processo técnico responsável pela ação. Gell vai dizer num texto curto a respeito da tecnologia do encanto e do encanto da tecnologia que "[q]uando a existência do objeto supera uma explicação, fascinando o espectador, nota-se que sua tecnologia real alcança o ideal mágico (2005 [1992], p. 41).

Em sua proposta de pensar a arte como componente da tecnologia, Gell (2005 [1992]) advoga que "[o] poder dos objetos de arte provém dos processos técnicos que eles personificam objetivamente: a tecnologia do encanto é fundada no encanto da tecnologia (Op. cit., p. 45). Ora, faz todo sentido pensar fotografia como resultado de processos técnicos que atuam na produção de objetos de arte; diga-se de passagem, a ambigüidade entre arte e tecnologia (aparato da ciência) parece rondar a fotografia desde seus primórdios (Ver Caiuby Novaes, 2015, e Rouillé, 2009). Como fruto de processos técnicos que resultam, nesta pesquisa, em objetos ou artefatos (de arte, da perspectiva de Gell), a fotografia entre os Asuriní nos permite estabelecer relações produtivas entre imagens, pessoas e magia $^{62}$.

62 Gell argumenta que, em comparação ao fascínio que exerce a pintura, a fotografia não atinge o mesmo prestígio pois é apenas uma "técnica de produção de imagens" e o fotógrafo, um modesto apertador de botões. Entre povos que não estão extremamente familiarizados com a câmera, o autor vai dizer que a situação é um tanto diferente: "Como muitos antropólogos que trabalharam sob tais condições terão como saber, a habilidade de tirar fotografias é freqüentemente tida como especial, uma faculdade oculta do fotógrafo, que se estende à posse das almas dos fotografados, por meio das fotos resultantes. Julgamos essas atitudes inocentes, quando se trata da fotografia [...]" (Gell, 2005 [1992], p. 51). Se as palavras de Gell sobre o fascínio que exerce a fotografia em sociedades que não estão familiarizadas com essa tecnologia se aplica ao caso asuriní, discordo absolutamente de que tal fascínio seria resultado de uma atitude inocente dos índios. 0 poder da fotografia, neste tipo de sociedade, passa ao largo de ser infundado, e explorar este ponto é parte do trabalho a que esta tese se dedica. 
Caiuby Novaes, em seu texto "Imagem, magia e imaginação - desafios ao texto antropológico", publicado pela revista Mana em 2008, afirma que a imagem compartilha com a magia várias características, a começar pela origem etimológica ${ }^{63}$. A autora cita Olgária Matos quando supõe uma origem comum, no persa antigo, para imagem e magia. Definida como "instância intermediária entre o sensível e o inteligível", a imagem é a "imaterialidade material" (Caiuby Novaes, 2008, p. 455-456). Imagens, especificamente as que resultam de modernas técnicas de reprodução, entre elas as fotográficas, são signos que pretendem completa identidade com o que apresentam, o que nos ilude em sua aparência de naturalidade e transparência, a qual esconde os inúmeros mecanismos de representação de que resultam (Op. cit., Ibid.).

A representação de pessoas em fotografias e retratos é evocada por Gell em outro trabalho (1998), para citar mais um exemplo de agência de imagem. No entanto, ao contrário do que poderíamos pensar, o autor não atribui a agência da fotografia apenas aos povos ditos primitivos que vivem em tribos e que acreditam que suas almas estão em perigo por terem sido roubadas pelo retrato, mas afirma que todos têm motivo em querer controlar a circulação de suas imagens fotográficas.

No capítulo dedicado à noção de pessoa distribuída, Gell vai buscar em Frazer uma distinção dos modos de operação da magia para falar da agência das imagens. Frazer distinguiu dois modos básicos de ação mágica: magia por contágio, que é a magia de contato na qual influências passam de um objeto a outro, e magia por similaridade, que depende de propriedades compartilhadas, o que significa que, se um objeto A partilha propriedades com o objeto B, A exerce influência sobre B e vice-versa.

Posteriormente a Frazer foram realizados outros estudos sobre o tema da magia, entre os quais um dos mais completos é o "Esboço de uma teoria geral da magia", escrito por Marcel Mauss com a colaboração de Henri Hubert (2003

\footnotetext{
${ }^{63}$ As articulações entre magia e fotografia apresentadas nesta seção foram inspiradas na leitura do artigo de Caiuby Novaes (2008). Outras reflexões sobre o tema foram realizadas por Grunvald e por mim no artigo: "Alguns apontamentos sobre fotografia, magia e fetiche" (no prelo).
} 
[1902-03]). Apesar de a magia dar a impressão de ser uma gigantesca variação sobre o tema da causalidade, Mauss propõe pensá-la como uma espécie de ciência e se dedica a entender o que chama de representações ou suas leis dominantes (2003 [1902-03], p. 100). A partir da lei da contigüidade, as coisas em contato estão ou permanecem unidas; da lei da similaridade, o semelhante produz o semelhante; e da e lei da contrariedade, o contrário age sobre o contrário.

A vulnerabilidade para a feitiçaria só acontece porque existe a difusão da pessoa no meio em que vive. Frazer já havia notado que a feitiçaria baseada na imagem é muito próxima da feitiçaria que depende dos exuviae ${ }^{64}$, que são partes do corpo como unhas, cabelo, excrementos, restos de comida, que têm, de alguma forma, ligação com uma pessoa. A feitiçaria pelas exúvias acontece pelo nexo causal que existe entre a pessoa e suas partes dispersas, como fragmentos destacados de si ou como a "pessoa distribuída" para além dos limites de seu corpo. 0 que este tipo de feitiçaria nos apresenta, e que interessa para o estudo de imagens como índices de algo ou alguém, é o link direto que pode ser estabelecido entre o índice como a imagem de um protótipo e o índice como uma parte (destacada) do protótipo. Com isso, e a partir de Gell, podemos pensar as imagens (mesmo retratos e fotografias) como parte das pessoas.

Numa abordagem completamente diferente, Dubois 2014[1990] também trabalha com a ideia da fotografia como índice ${ }^{65}$. Na perspectiva do autor, a imagem fotográfica se torna inseparável de sua experiência referencial, do ato que a funda: "Sua realidade primordial nada diz além de uma afirmação de existência. A foto é em primeiro lugar índice. Só depois ela pode tornar-se parecida (ícone) e adquirir sentido (símbolo)" (Op. cit., p. 53, grifos do autor). 0 ponto de partida, aqui, é a natureza técnica do processo fotográfico, ou seja, o princípio elementar da impressão luminosa regida pelas leis da física e da química, de

${ }^{64}$ Termo utilizado no texto original em inglês (Gell, 1998, p. 103); adotamos aqui a tradução: exúvias. Cf. Dicionário Michaelis on line. Disponível em: http://michaelis.uol.com.br/.

650 autor toma a noção de índice de Pierce: "(...) Chamo de índice o signo que significa seu objeto somente em virtude do fato de que está realmente em conexão com ele" (Pierce apud Dubois, 2014[1990], p. 62, grifos do autor). 
modo que o valor icônico decorre do indicial. Para Dubois, as fotografias se parecem exatamente com os objetos que representam devido a circunstâncias em que elas foram fisicamente forçadas a corresponder, ponto a ponto, ao seu referente 66 .

Como signo por conexão física marcado pela semelhança, a representação fotográfica se encontra bastante próxima das leis mágicas enunciadas por Frazer e por Mauss. De fato, para falar apenas da menos óbvia lei de contigüidade, a fotografia partilha de princípios da magia por contato, assim como definida por Mauss:

\begin{abstract}
A forma mais simples dessa noção de contigüidade simpática nos é dada na identificação da parte ao todo. A parte vale pela coisa inteira. Os dentes, a saliva, o suor, as unhas, os cabelos representam integralmente a pessoa; de tal modo que, por meio deles, pode-se agir diretamente sobre ela, seja para seduzi-la, seja para enfeitiçá-la. A separação não interrompe a contigüidade, pode-se mesmo reconstituir ou suscitar um todo com o auxílio de uma de suas partes: Totum ex parte (2003 [1902-03], p. 100).
\end{abstract}

A fotografia, assim como a magia, não pode viver de abstração; uma foto é sempre uma foto de algo ou de alguém, e ambas, foto e magia, só existem na sua relação com o mundo sensível e concreto. Mauss vai dizer que os ritos mágicos explicam-se muito menos facilmente pela aplicação de leis abstratas do que como "transferência de propriedades" cujas ações e reações são previamente conhecidas (Mauss, 2003[1902-03], p. 111). Em um texto curto acerca da ontologia da imagem fotográfica, Bazin (1991[1945]) explicita a originalidade da fotografia em relação à pintura: sua objetividade. A fotografia, segundo esse autor, "[...] se beneficia de uma transferência de realidade da coisa para a sua reprodução" (1991[1945], p. 22), o que Caiuby Novaes (2008) aponta como, justamente, a magia da imagem.

66 Dubois (2014[1990], p. 67) vai dizer: "A fotografia não é a priori mimética. 0 analogismo figurativo da foto com seu referente é um efeito e não é primordial, resulta de uma certa organização dos cristais de haleto de prata da emulsão, que reagem ao impacto dos raios luminosos emitidos ou refletidos pelos objetos do mundo exterior constituindo plagas mais ou menos diferenciadas, que se estruturam aos poucos em imagens eventualmente reconhecíveis como tendo as mesmas aparências que as dos objetos aos quais emanam". 
A partilha de propriedades também é central na noção de mimesis desenvolvida por Michael Taussig. Em seu livro Mimesis and Alterity, o autor busca articular a teoria da magia de Frazer com algumas discussões que extrai da obra de Walter Benjamin. Seu argumento explora como "a noção de cópia, na prática mágica, afeta o original de tal forma que a representação comparte ou adquire as propriedades do representado" (1993, p.47-48).

No início de seu livro, Taussig oferece a definição de mimesis que retomará inúmeras vezes ao longo do texto: "a faculdade mimética é a natureza que a cultura usa para criar uma segunda natureza, a faculdade de copiar, imitar, criar modelos, explorar diferenças, entregar-se e tornar-se outro [...] Para usar uma linguagem antiga isso é magia simpática" (1993, p. xiii).

Ao contrário do que poderíamos supor, a noção de mimesis não se relaciona apenas com a magia por similaridade. Taussig, ao enfatizar o conceito de "faculdade mimética" de Benjamin, insiste na ideia de "tactilidade ótica", união do objeto da percepção com o corpo daquele que percebe. A magia da imagem não estaria apenas em sua semelhança visual, mas também nas propriedades compartilhadas; poderíamos conjeturar, de certa forma, em uma conexão substancial e em termos de transferência material.

A "transferência de propriedades" da coisa para a sua reprodução pode ser pensada, entre os Asuriní, em termos da consubstanciação do ynga entre pessoa e imagem. Assim, uma imagem fotográfica é parte da pessoa ou é a pessoa distribuída, nos termos de Gell. Se a partilha do ynga nos aproxima da magia por contágio, a noção asuriní de ayngava nos permite estabelecer uma afinidade direta com a ideia de mimesis de Taussig - que tenderia mais para a magia por similaridade ou imitação, embora esta lei não seja exclusiva, como acabamos de mostrar. Como vimos no capítulo 1, a raiz ayng corresponde ao verbo imitar, e são diversas as interdições relacionadas à imitação de seres e espíritos pelo perigo de provocá-los ou atraí-los de forma descontrolada. Os Asuriní apontam, portanto, para a compreensão da fotografia enquanto objeto que apresenta uma semelhança com o representado (imita a pessoa, ayngava), ao mesmo tempo em que ela estabelece uma relação de contigüidade com o referente (partilha o ynga). Como vemos, não faltam motivos para que ela se preste, de maneira 
exemplar, às práticas mágicas.

\subsection{Consubstanciação do ynga entre pessoas, espíritos e imagens}

Tayngava, um paradigma para a fotografia

A agência do boneco antropomórfico tayngava, feito de taquarinha e encapado de algodão, usado pelos xamãs Asuriní em alguns rituais de cura, permite-nos estabelecer novas relações entre imagem, pessoa e substância.

Como já se mencionou no primeiro capítulo, Müller define o sufixo "t" da palavra tayngava como possuidor humano, de modo que tayngava seria a imitação, imagem e réplica do ser humano, diferente de avarayngava, nome dado à representação de uma pessoa em um desenho. Tayngava é tanto o padrão da maior parte dos grafismos, nome do traço mínimo do desenho, que pode ser considerado o braço/perna desta figura, quanto o objeto feito de taquarinha associado à noção de ynga (princípio vital), compartilhado entre humanos e espíritos, manipulado pelo xamã.

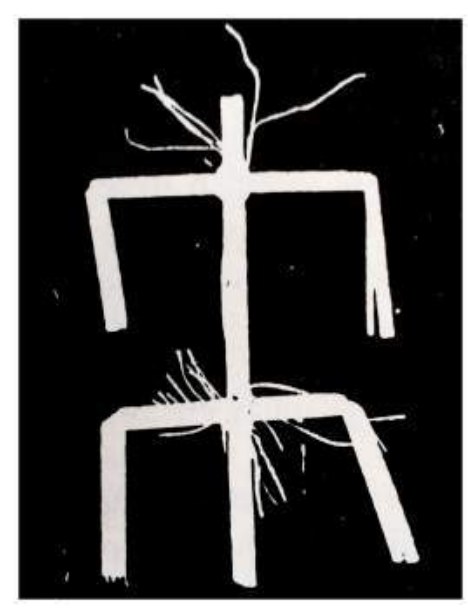

Imagem 1

O boneco tayngava

Fonte: Müller, 1993, p. 243.

Utilizado no contexto dos rituais xamanísticos, o tayngava enquanto boneco antropomórfico pode provocar processos incontroláveis, pois o ynga, em 
sua representação plástica, é perigoso. 0 risco do tayngava, segundo Müller (1993), está na consubstanciação do elemento básico de manipulação do xamã, o ynga, substância perigosa por sua própria função de intermediação e mistura de planos cósmicos - passa de uma zona do cosmo a outra - e entre humanos e não humanos. Com Gell, poderíamos dizer que o boneco antropomórfico tayngava, que contém ynga, é perigoso porque, na representação plástica, o ynga passa a ter a forma de um objeto e os objetos na vizinhança de relações humanas possuem agência social.

O tayngava é uma espécie de spirit catcher que pode ser encontrado em outras sociedades indígenas. Barcelos Neto (2001, p. 144) cita o uso desse tipo de boneco de fibra vegetal entre os Wauja, designado ĩ yãu opotalapitsi, e registra, a partir de outras etnografias ${ }^{67}$, o mesmo boneco: yakulátsa entre os Yawalapíti, kefegé, entre os Kuikuro e ta'angap, entre os Kamayurá. De modo geral, nas diferentes etnografias, o boneco parece ser usado em contextos de cura xamanística, utilizado para alojar temporariamente a alma roubada do doente, como no caso waujá etnografado por Barcelos Neto:

[...] o xamã defuma a boneca: ela está, então, potencialmente viva para alojar temporariamente a alma roubada ao doente. Em seguida, a boneca é levada até onde se encontra o apapaatai, que está em posse da alma do doente [...]. Depois de um esforço colossal o xamã consegue tomar a alma do apapaatai e colocá-la na boneca. Esta contém agora a substância vital do doente. Por um processo de transubstanciação, a boneca torna-se a imagem viva do doente (Barcelos Neto, 2001, p. 144).

Manuseado pelo xamã, o tayngava é capaz de "guardar" a substância vital da pessoa que a perdeu. Mas, para além da ideia de que este objeto possa funcionar como parte destacada da pessoa, o tayngava nos diz sobre sobre a centralidade da imagem na constituição da pessoa. Se o tayngava enquanto imagem representa partilhando substâncias com o seu protótipo, a pessoa é a imagem, e a imagem da pessoa (podemos também estender esta afirmação para a fotografia) é constitutiva do ser. A ideia de Da Matta (1976) de que o processo

${ }^{67}$ De acordo com as etnografias de Carneiro (1977), Viveiros de Castro (1977) e Menezes Bastos (1984-85). 
de consubstanciação, produzido pela partilha de substâncias tais como comida e fluidos corporais, como cheiro e memórias dos cuidados recebidos, corresponde ao processo de fabricação da pessoa nas sociedades ameríndias, ressoa muito bem no material asuriní, entre os quais processos de consubstanciação e partilha de ynga entre seres viventes é focal, desde que se pense que a imagem é parte da pessoa e atua, não apenas na fabricação dos corpos, mas também opera metamorfoses e desintegrações, poderes investidos pela partilha do ynga.

Na etnografia asuriní (Müller, 1993, p. 244-251), o tayngava é elemento simbólico que representa o princípio constitutivo da categoria de humano (isto é, vivente, uno) compartilhado entre os seres que possuem ynga. Tayngava é a noção por excelência que representa, mas representa partilhando o ynga e, portanto, diz respeito à noção da própria representação (imagem) como constitutiva do ser. A partir do estudo do tayngava, Müller afirma (Op. cit., p. 251) que a ideia de representação, longe de se assemelhar ao modo como aparece no pensamento ocidental - em que imagem de algo implica ausência pois é repetição do que não existe -, entre os Asuriní seria colocada de uma forma diferente; a representação não remete a algo falso, ela faz existir.

Enquanto objeto, o tayngava é simples, de aspecto pouco acabado e sem ornamentação; possui todos esses traços que tomamos por uma "falta de arte" (Cf. Taylor, 2010). O tayngava é uma imagem genérica e sua identidade, suscetível a permanecer indefinida, pois é um suporte provisório da substância vital da pessoa que está doente ou de substâncias transmitidas pelos espíritos.

Contudo, apesar de propor aproximar o objeto tayngava das fotografias, devo reconhecer que as particularidades formais deste objeto nada se aproximam das fotografias que, longe se serem genéricas e de poder corresponder a diferentes tipos de encarnações corporais, remetem, sempre, a uma pessoa ou objeto específico. O que os aproxima enquanto objetos é que ambos são imagens materiais que carregam ynga. 0 que desejo elucidar é que a lógica da agência da imagem expressa em sua forma máxima no boneco tayngava, usado pelos xamãs nos rituais xamanísticos, é operativa na relação que os Asuriní estabelecem com a fotografia. A imagem fotográfica não substitui a pessoa, mas se torna um ser em si mesmo, que é parte da pessoa, e eis aqui o seu 
perigo: agir de forma descontrolada sobre o corpo da pessoa fotografada, tendo em vista a consubstanciação do ynga entre pessoa e imagem.

Fluxos do ynga nos processos de cura e tratamento

Por intermédio das relações estabelecidas entre imagem e princípio vital, ayngava e ynga, respectivamente, como compreender a agência da fotografia no adoecimento e morte dos índios partindo das noções de cura e doença da perspectiva asuriní?

O estado de doença entre os Asuriní está associado à perda de algo pela pessoa; quando se transpira muito, como o suor num indivíduo febril, está-se perdendo ynga. 0 indivíduo considerado doente é imaryna e a posição do paciente nos rituais terapêuticos é imunara. Imaryna se refere a algo que está se acabando, como um fruto podre ou semidestruído (Müller, 1993, p. 168). Nas cerimônias do Turé, os imunara são os guerreiros (boakara) que devem ser tatuados para tirar do seu corpo o sangue do inimigo morto; neste caso, o desequilíbrio gerado se dá pelo excesso de ynga do inimigo: “[...] o sangue da vítima 'fica na barriga, dói e pode lhe fazer mal'" (Op. cit., p. 170).

As doenças podem ser causadas por diversos fatores, sempre associados à introdução de alguma substância nociva no corpo do indivíduo - como, por exemplo, a inserção (pelos espíritos) de pequenas flechas no corpo da pessoa próximo a órgãos como o coração ou o fígado, ou a algo que se perde do corpo como, por exemplo, a perda de ynga através do suor num indivíduo febril. Esses mesmos movimentos de tirar e pôr substâncias no corpo do paciente são realizados pelos xamã Asuriní durante o rito do petymbo, nos rituais maraká terapêuticos. Ele tira o que deve sair, o que estiver causando a doença, e coloca a substância vital, ynga. Segundo Müller (1993, p. 170), no corpo do doente o ynga é introduzido e "guardado dentro" por meio de massagens, fumaça de tabaco e mingau ingerido pelo paciente.

O xamã obtém o ynga dos espíritos. Os Apykwara, Tivá e Karovara, espíritos xamãs primordiais, dão ynga para o tratamento dos doentes e são 
chamados para dançar e tomar mingau com os xamãs, transmitindo-lhes também o moynga, espécie de ynga suplementar que os Asuriní traduzem como remédio ou xarope. Nos rituais propiciatórios, ligados à caça a à agricultura, os espíritos do porco-do-mato (Tajaho) e do veado (Arapoá) também dão ynga. É nesse sentido que o ynga é o princípio vital existente, não só no corpo das pessoas, mas elemento constitutivo de seres viventes (humanos, espíritos e animais), e também extensivo aos resultados das ações que esses seres executam sobre a natureza, como a caça e a agricultura (Müller, 1993, p. 171).

As relações entre humanos e espíritos na ação ritual são ambíguas. Os espíritos ("visitantes") são trazidos à aldeia e se hospedam nas casas feitas especialmente para eles, as tukaias, e ao lado dos humanos bebem mingau e fumam tabaco, em troca do ynga que oferecem. Com os espíritos se mantém a mesma relação que se tem com uma presa animal, tentando-se capturá-los quase que à força com o auxílio de "iscas”, os yvara - troncos de madeira decorados.

Xamãs e espíritos têm em comum o poder de transformações pelo uso do tabaco. Yvara, símbolo do charuto de tabaco, representa a ligação entre os espíritos e os humanos, pois os espíritos amarram nele seu transporte de algodão (y'ima) enquanto dançam e participam da refeição comum com os xamãs. Yvara é, por excelência, o lugar dos espíritos na aldeia dos humanos, e nele o xamã pega o moynga dos espíritos xamãs primordiais. 0 charuto decorado, do qual o yvara é uma réplica, é usado no rito de transmitir ynga dos espíritos aos pacientes.

Não apenas processos de consubstanciação, partilha do ynga entre seres diferentes, mas também transubstanciação, processo de passagem de uma substância a outra, como no caso do ynga em alimento, caracterizam os movimentos do ritual maraká. O ynga é a substância por excelência que estabelece a relação entre a série humana e a não humana no ritual; se é partilhada entre seres viventes, também é fornecida pelos espíritos na cura e no fortalecimento dos doentes.

As fotografias tiradas pelos padres católicos no contato com os Asuriní apresentam efeitos danosos, não apenas porque a imagem materializada da pessoa é extremamente perigosa - na medida em que a fotografia enquanto objeto adquire agência descontrolada -, mas também porque a agência do ynga 
pertence ao xamã e aos espíritos nos processos associados à consubstanciação e à transubstanciação do princípio vital. A manipulação do ynga fora dos rituais xamanísticos pode ser bastante arriscada.

Durante o período de 1976 a 1982, época em que a população asuriní entrou em escala declinante e que a ameaça de extinção física se fez presente, as atividades rituais foram realizadas com grande vitalidade. Müller (1984-85, p. 108) interpreta a intensificação dos rituais asuriní nesse período como a reafirmação dos valores do grupo e de sua visão de mundo, num esforço de reorganização tribal. A convivência irreversível com seres diferentes, amistosa e ameaçadora, sejam eles alteridades sobrenaturais ou sociais, é vivida na ação ritual, estando prevista na cosmologia.

Neste período pós-contato, em que o convívio com a sociedade nacional é marcado pela aquisição de muitas doenças que levaram a mortes, a fotografia age causando efeitos danosos. Como objeto patogênico, ela está associada à agência de seu produtor, objetivando relações de desconfiança e conflito entre os Asuriní e os brancos.

\subsection{Brancos, feiticeiros e inimigos}

Sugerimos, até aqui, que os efeitos danosos da representação dos Asuriní nas fotografias tiradas pelos padres católicos remetem às aproximações entre retratos e práticas mágicas e de feitiçaria. Sem pretensão de discorrer sobre o tema da feitiçaria entre os Asuriní68, assunto em que não tive oportunidade de aprofundar, teço alguns comentários a respeito de acusações direcionadas aos brancos, a partir de dados de campo.

É comum os Asuriní mencionarem que os xamãs de antigamente, quando ficavam com raiva de alguém, podiam matar ou fazer adoecer uma vítima sonhando com ela. Nestes casos, sonhavam que comiam o coração, o fígado e os efeitos eram sentidos de imediato pela pessoa, que podia ser, inclusive, uma criança ou um não-índígena. Não apenas os xamãs podiam agir mortalmente em

\footnotetext{
${ }^{68} \mathrm{~A}$ respeito da feitiçaria entre grupos tupi, ver por exemplo o trabalho de Figueiredo (2010), que estudou o tema entre os Aweti.
} 
prejuízo de seus alvos; pessoas comuns também o faziam, mas a partir de práticas diferentes como, por exemplo, manipular substâncias em alimentos a serem ingeridos pela figura que se desejava atingir. Tais práticas são sempre situadas temporalmente no passado e, embora eu os tenha questionado se os pajés ainda sonham deste modo ou se o envenenamento é comum, me respondiam sempre com frases do tipo: os "antigos que faziam", "pajé antigo que matava assim".

A respeito dos envenenamentos, Takamuin ${ }^{69}$ me forneceu alguns exemplos. Colocar marupá potyra (flor de marupá70) nas carnes de jabuti (jautimutava, em que mutava = carne), cotia (acotimutava) ou de porco (tajahomutava), ou, então, ossos de veado (arapoakynga, em que akynga = osso), de nambu (nambuakynga) e de cotia (acotiakynga) raspados no mingau, e ainda adicionar fezes de gavião (tevutiokandô) aos alimentos ingeridos pela vítima. 0 efeito imediato é uma forte dor de barriga (jepepyverap = minha barriga dói) que pode levar à morte.

As acusações de manipular substâncias nos alimentos com intenções nefastas são estendidas aos brancos, e aparecem em meio a memórias carregadas de medo e angústia dos primeiros anos pós-contato. Takamuin afirmou que, assim que a Funai assumiu a "atração" dos Asuriní nas margens do Ipiaçava, o sertanista Antônio Cotrim Soares e sua equipe ofereceram café amargo em latas grandes e obrigaram os índios a tomar. Ele lembra da catástrofe que se seguiu após beberem o café.

Demorou um pouquinho depois que eu tomei. Fui me deitar e fiquei escutando a minha barriga roncar [faz som do ronco]. Café fez mal pra mim, eu vou cagar, eu vou cagar de novo. Na terceira vez eu já estava bem fraquinho. E o outro pessoal também disse: "Eu vou cagar, vou cagar, vou cagar". Todos foram. Caguei lá embaixo da minha rede mesmo, tinha uma panela bem grande, foi lá mesmo, cagava lá dentro. Era que nem água descendo, era direto. "Rapaz, esse negócio aqui não vai parar não?". Eu

\footnotetext{
690 índio se referiu aos envenenamentos pelo termo murumungaruaiva e explicou que significa "dar comida ruim". Num ritual maraká que assistiu em 1986, Müller (1993, p. 169) conta que uma das pessoas na posição de paciente era uma mulher que em poucos dias perdera a locomoção das pernas devido a um feitiço por meio de algo colocado na sua comida, Müller usa o termo oforomogaroaip para se referir ao envenenamento. Guardadas as diferenças na forma de grafar, os termos se aproximam.

${ }^{70}$ Desconheço o nome regional da planta, bem como seu designativo científico.
} 
estava muito fraco e como a maioria estava ruim ninguém dava comida para o outro. Nós tudinho tava ruim. Aí no outro dia Uarapé morreu e depois foi outro homem que morreu. Morreu e ninguém enterrou ele porque ninguém tinha força. Eles cavavam só um pouquinho e enterravam alguns mas outros eles deixavam ${ }^{71}$.

0 relato na íntegra cita o nome de mais de dez pessoas que teriam morrido após a ingestão do café: a mãe dele (Ipikiri) e seu marido, seu tios (Manakare'yva e Pamevyra), a mulher de Pamevyra, seu primo (Uruá), sua tia (Pirapevi), Pinavipé, Apirijú, Tyapirurú, Tukura, Kupekynga, pai de Myrá (Kupen) e a mãe do Takiri. A percepção do índio era de que os "Asuriní estavam se acabando" e que ele não demoraria muito em ser a próxima vítima.

Takamuin contou que, na ocasião, fez um esforço em entender o que os brancos "estavam querendo" com eles. Espiava o que aqueles homens faziam e ouvia suas conversas para, quem sabe, deduzir quais eram as intenções dos akaraí. Apesar da dificuldade com o português que ele pouco dominava teria, enfim, entendido: os brancos pretendiam matá-los, mas não de uma única vez, programavam fazê-lo aos poucos.

Muitas acusações foram dirigidas aos funcionários da Funai. Não foi só o café que fez mal. Outros alimentos como mingau e caldo de pirarara (nome regional de um tipo de peixe de couro) envevenados foram oferecidos aos índios causando, igualmente, fortes dores de barriga. Os alvos dos brancos eram as pessoas que se mostravam insatisfeitas com a atuação da Funai e que por isso, reclamavam ou falavam mal do trabalho dos funcionários do órgão indigenista. Diante do crescente número de mortes e adoecimentos, a Funai se portou com descaso: "não davam remédios, nem mandavam a gente se tratar na cidade", o que, segundo Takamuin, só reforçou a desconfiança dos índios.

Apesar de ser acusado pelos Asuriní, o sertanista Antônio Cotrim Soares, que liderou a "atração", reconheceu a negligência da Funai na ocasião. Cotrim se demitiu dando um célebre depoimento para a imprensa da época declarando que

\footnotetext{
71 O depoimento foi proferido na língua em maio de 2015; obtive a tradução com a ajuda da índia Ipikiri.
} 
estaria cansado de ser "coveiro de índio" e "administrador de cemitérios indígenas"72.

Até hoje os Asuriní desconfiam dos alimentos oferecidos pelos brancos. Takamuin conta que a Nesa - Norte Energia, consórcio que está construindo a hidrelétrica de Belo Monte, teria mandado, no ano 2012, inúmeras garrafas de refrigerante abertas para a aldeia como parte de uma das ações compensatórias do empreendimento. As dores de barriga que acometeram muitos dos índios que ingeriram a bebida foram consideradas indício da tentativa de envenenamento, e as garrafas abertas, a prova das más intenções.

Nos relatos acerca do contato por mim coletados (que serão abordados no próximo capítulo), os Asuriní se referem aos brancos, bem como aos grupos com quem guerreavam, pelo termo tapy'yia, inimigos. Alguns me explicaram que o termo akaraí veio depois, para diferenciar os brancos dos outros tapy'yia, que também possuem seus designativos próprios: Ararava é a forma como se referem aos Araweté, e Kaiapu, aos Kaiapó.

$\mathrm{Na}$ mitologia asuriní os inimigos aparecem associados à figura dos kava, marimbondos, e, segundo me contaram diversos índios, foi o herói criador Maíra quem os fez. Souza (1994), que coletou em seu trabalho relatos acerca da origem dos akaraí, apresenta uma narrativa de Kurijá (pajé já falecido) em que ele conta: "Maíra fez akaraí com tipo de kava chamado 'soldado bravo', por isso akaraí mata muito Asuriní" (1994, p. 141). Segundo a autora, os akaraí - ou kava karaí, um tipo de marimbondo amarelo - eram muito bravos antes da chegada do padre Antônio; depois, teriam deixado de ser tão bravos. Na ocasião de sua pesquisa de campo, no início da década de 1990, os índios também teriam afirmado que "muitos [akaraí] são bons para a gente, gostam dos Asuriní" (Op. cit., p 146).

72 Cotrim Soares acusou a Funai de não ter lhe provido de condições de trabalho adequadas, e, a expedição de Lukesch, pela falta de medidas preventivas que geraram a contaminação do grupo com doenças e epidemias. Mais informações no verbete Asuriní do Xingu na Enciclopédia dos Povos Indígenas do ISA- Instituto Socioambiental (ver: http://pib.socioambiental.org/pt/povo/asurini-do-xingu/1278. É sabido o papel que o sertanista teve na denúncia do "extermínio" das populações indígenas brasileiras; para mais informações, ver: http://armazemmemoria.com.br/acervos-pessoais-antoniocotrim-soares/. 
Souza reconhece a ambigüidade que representa a figura do branco, pois ao mesmo tempo em que são "bons", podem voltar a qualquer momento a serem chamados de inimigos. 0 perigo que amedrontava os índios na ocasião era a construção da barragem no Xingu, projeto que saiu do papel e nos dias de hoje se tornou uma realidade, o que, certamente, reforçou as ambigüidades e tensões implicadas no relacionamento com os brancos.

A figura dos tapy'yia aparece na narrativa que conta a história de como os espíritos-xamãs primordiais Apykwara e Karovara deixaram a terra e foram definitivamente para o céu, depois de entrarem em contato com pedaços do corpo de um inimigo morto.

De modo resumido, a narrativa que me foi contada por Boaiva (em outubro de 2012) se inicia quando Andirá (morcego) tem um filho que logo morre. Um pássaro de nome Japií, com a ajuda de outros pássaros, faz uma casa (tavyve) para enterrar o filho do morcego. Depois de enterrarem eles fazem festa. Em seguida, vão brigar com os inimigos (kava, marimbondos). Se aproximam da aldeia dos inimigos com medo mas, mesmo assim, fazem guerra e os matam. Asigaô (um tipo de pássaro) corta o braço e a cabeça do tapy'yia e leva embora. Ao chegarem de volta em casa, encontram Tivá, Apykwara e Karovara fazendo festa (ritual xamanístico). Uirasimé, moça cantadora que auxilia os xamãs no ritual, está preparando mingau e pergunta para o boakara (guerreiro): "0 que você traz?". "Trago cabeça, braço", ele responde. Então, ela pega os pedaços do corpo e leva para a aldeia. 0 braço do inimigo morto agarra na casa onde os pajés estão e eles perdem os sentidos ("morrem", como dizem os Asuriní). Apykwara fica bravo, ele e Karovara deixam a terra e sobem ao céu levando a casa com eles $^{73}$.

Neste relato, os tapy'yia aparecem por meio de duas imagens, como os kava, marimbondos, e enquanto partes do corpo (cabeça, braço) do inimigo morto pelo boakara (guerreiro). Sem pretender ir muito longe, noto apenas que seja como kava ou como "corpo em pedaços", os inimigos são dotados de agência

\footnotetext{
$73 \mathrm{O}$ relato continua e narra os acontecimentos pelos quais passam Apykwara e Karovara em seus caminhos celestes; reproduzo apenas a primeira parte do relato pois é nela que aparecem os inimigos. Uma narrativa muito semelhante foi registrada por Müller em 1981. Ver Müller, 1993, p. 331-333.
} 
predatória $^{74}$. A experiência de fazer uma expedição por mais de vinte dias pelo igarapé Piranhaquara me instruiu a respeito do poder nefasto dos marimbondos que, embora pequenos, constituem-se como forte ameaça se seus cachos se colocam no caminho para os roçados, trilhas de caça ou mesmo nas margens de um igarapé, como a situação que presenciei. Comportamento parecido ao dos marimbondos tem os pedaços do corpo do inimigo no relato narrado. Braços, pernas e cabeça são síntese da desintegração da pessoa, do "eu dividido", e passam a ter agência. 0 contato dessas partes do corpo do inimigo morto com os xamãs Apykwara e Karovara é responsável pela sua retirada definitiva para o céu.

Para evitar o contágio com o sangue da vítima, os Asuirní realizam as tatuagens do boakara (guerreiro) dentro dos complexos rituais Turé - momento em que também choram os mortos, separando-os cosmicamente dos vivos. A tatuagem tem como efeito "tirar" o sangue da vítima do corpo do matador, pois a aproximação substancial entre matador e vítima é perigosa e pode levar o guerreiro à morte.

Em outro relato mítico, os brancos também aparecem como figuras com as quais se travam relações belicosas, sendo mencionados como os yarakynga (yara $=$ canoa e akynga $=$ cabeça $)$. A narrativa conta como Maíra, o herói criador, concebeu o mundo dando vida às coisas com baforadas de cigarro ${ }^{75}$. Na passagem em que Maíra está pescando com êxito, Kyty (sua criatura) tenta e não consegue pegar um único peixe. No igarapé em que estão, passam os yarakynga em suas canoas e Kyty, então, com medo, decide só passar pelo rio de noite para não ser visto. Numa outra versão, contada por Takamuin, os akaraí aparecem na

\footnotetext{
74 Van Velthen (2003) faz uma interessante análise sobre estética da predação $x$ estética da metamorfose wayana na qual os animais quatipuru e maguari estariam associados à predação enquanto larvas e borboletas, à metamorfose. Os animais aqui são metáforas visuais boas para pensar, para lembrar Lévi-Strauss (2004[1964]) e o mundo sensível, de onde os mitos tiram sua matéria-prima.

${ }^{75}$ Refiro-me às versões contadas pelos xamãs Boaiva e Parajuá em comunicação pessoal durante trabalho de campo em 2012 e à versão registrada por Müller em 1981, contada por Tavayra e traduzida por Takiri. Ver Müller, 1993, p. 323.
} 
mesma passagem do relato anterior, enquanto Kyty tenta atravessar o rio, mas não são yarakynga e sim kava (marimbondo) "virando gente"76.

A figura dos yarakynga presente na narrativa de Maíra coincide com a dos brancos avistados em suas canoas - ribeirinhos, extratores de caucho e gateiros, que os índios encontravam pelo menos desde o fim do século XIX, segundo os registros históricos 77 , no interflúvio Xingu-Tocantins, sua região de perambulação. Tais encontros eram carregados de belicosidade, e muitos brancos foram mortos por Asuriní. Mure'yra, por exemplo, exibe suas tatuagens com orgulho e me conta que só matou akaraí, o que lhe rendeu muitas participações como boakara nos rituais do Turé.

\subsection{Os anhynga e a morte}

O espectro anhynga e a desintegração da pessoa

A ocasião em que ouvi pela primeira vez comentários sobre o perigo que representam os espectros dos mortos, se deu de forma curiosa durante pesquisa na aldeia Koatinemo. Como forma de introduzir o tema da seção, me reporto a um episódio vivido em campo, por meio do qual passei a conhecer um pouco a respeito dos anhynga.

Desde que os aparelhos de televisão e DVD passaram a integrar o cotidiano dos Asuriní, há pouco menos de dez anos, quando a luz do dia cai e o gerador é ligado, cada núcleo familiar se reúne em torno das sessões de filmes adquiridos a baixo custo em Altamira, quase todos estadunidenses. Os Asuriní preferem os gêneros de ação, aventura e terror, especialmente se apresentarem boas cenas de luta, guerras e perseguições, com muitos efeitos especiais.

Em meados de 2012, a aldeia vivia uma febre por filmes de terror. $O$ Brinquedo Assassino (1988, direção de Tom Holland, EUA) e Floresta do Mal Caminhos da morte (2009, com direção de Declan O'Brien, 2009, EUA) eram dois

\footnotetext{
76 Takamuin encontrou uma expressão muito interessante para apontar para a constante transformação dos seres antes da especiação; ele explica que akaraí "era marimbondo e era gente".

77 Cf. Nimuendajú (1948) e Coudreau (1977[1897]).
} 
filmes que circulavam de casa em casa durante as sessões noturnas. Chamava atenção a proximidade dos temas dos filmes com enunciados privilegiadamente ameríndios: Chucky, o boneco assassino que rouba a alma do menino e passa a cometer crimes em $O$ Brinquedo Assassino, ou então, um matador canibal que corta os pedaços das vítimas e pendura em um casebre na mata em Floresta do Mal... Este último me sugeria de imediato uma passagem da narrativa do espírito Apykwara, que acabamos de mencionar, quando os "pedaços do corpo" do inimigo morto agarram na casa onde ele e Karovara faziam festa.

Todas as noites eu assistia aos filmes junto ao núcleo residencial de Matuia, sempre impressionada com o fato de que as crianças pequenas eram as que mais se divertiam e que nenhum tipo de interdição lhes era imposta. Num dos dias, após assistir ao filme Floresta do Mal - Caminhos da morte, o jovem garoto Ararimyna, filho de Matuia, teve um sono turbulento, vidrado que estava com imagens do canibal deglutindo pedaços humanos num casebre na floresta. Matuia me procurou na manhã do dia seguinte para contar que seu filho acordara no meio da noite em prantos dizendo ter sonhado com anhynga. Quando chego ao espaço externo da cozinha em que se reuniam os filhos e o esposo de Matuia, percebo que estão todos rindo e caçoando do rapaz pelo fato de as imagens do filme o terem impressionado.

O episódio ocorrido com o jovem Ararimyna teve por efeito despertar relatos e narrativas sobre os espectros dos mortos. As crianças eram as mais entusiasmadas em me contar inumeráveis incidentes, esforçando-se, sempre, em me impressionar, aproveitando o ensejo de que eu dormia sozinha na residência dos pesquisadores. Time'y, irmão de Ararimyna, teria escutado, numa daquelas noites, anhynga na beira do rio Xingu, enquanto esperava seu irmão mais velho chegar de uma pescaria. Com medo, o rapaz correu imediatamente até a casa da mãe. Ocasiões como estas eram bons momentos para entender melhor sobre a presença destes espectros na vida asuriní, e eu aproveitava as brechas que me eram dadas, entre sessões de filmes de terror e conversas do dia seguinte.

Os Asuriní descrevem os anhynga como um ser pequeno, sem cabelo (gapina = careca), pele e olhos brancos, sem osso e magro; seu corpo é mole e seu andar frouxo pela ausência de estrutura óssea. Apesar de todos terem uma 
imagem figurativa desses espectros em mente - o que foi comprovado quando pedi às crianças que o desenhassem para mim - apenas os pajés conseguem vê-lo (pajé uesak = xamã vê). Os que não contam com as capacidades especiais escutam e sentem sua presença.

Na ocasião da morte de uma pessoa, seu anhynga é liberado, segundo relatos, depois de mais ou menos três dias, e se separa de suas demais partes constitutivas. Anhynga se refere à ausência e à divisão. Ausência de ynga (princípio vital), de ossos (gakynga), de pele (gapirera), apontando para uma pessoa dividida ou pretérita. Os Asuriní também se referem a este espectro como ynguera (ynga que foi) ou avaynguera (avá = gente, que foi gente). Anhynga tem um corpo mas é como se fosse vazio; nesse sentido, ele se parece bastante com o ta'o we Araweté, que é a "sombra livre projetada por um cadáver" ou o "duplo do cadáver" (marca de uma ausência). Sendo a sombra de um corpo ausente, ele é tudo, menos a pessoa, e, embora possa se assemelhar ao morto, é uma emanação, um efeito abstrato e impessoal: "O ta'o we, em suma, é algo que menos existe, antes insiste ou subsiste na superfície das coisas [...]. Ele é puro acontecimento, um efeito, uma persistência da memória. Nem ativo nem passivo, ou ambos - ou melhor, reativo-, ele é uma sombra, em extra-ser estéril e assignificante" (Viveiros de Castro, 1986, p. 506-507).

No cotidiano, os anhynga dos mortos são uma constante ameaça aos vivos, e é extensa a lista de cuidados e interdições a serem respeitados para manter, em relação a eles, uma boa distância. Após o falecimento de um parente, não se deve permanecer residindo na casa em que ele morou; o anhynga do morto pode retornar e incomodar os seus familiares. Ou então, queimar e destruir todos os objetos que pertenceram ao falecido. Nos dias atuais, até onde pude observar, os Asuriní não costumam mudar de casa na ocasião de um falecimento e podem conservar alguns objetos do morto, principalmente os utensílios industrializados como facões e espingardas.

Quando uma pessoa morre suas partes constituintes se separam: o ynga (princípio vital) vai para o céu, "sobe como avião, o pajé vê", disse Apebu. Este princípio animado da pessoa vai para mairakwera, o caminho onde mora Maíra, que se situa no lugar em que a água se encontra com o céu. Neste local, segundo o 
índio, as pessoas que morreram ficam para sempre novas. Os ossos (gakynguera, ga $=$ dele, $k y n g=$ ossos, era $=$ sufixo que indica passado, o que foi) ${ }^{78}$ são enterrados (utyn = enterrar) na tavyve (casa grande) e, portanto, ficam em um buraco no chão (avarivi yvyva) da casa comunal. 0 espectro anhynga da pessoa que morreu fica por um tempo perambulando nas matas ou roças abandonadas, as capoeiras (kafera).

Os xamãs e as tauyva, mulheres cantadoras da festa Tauva, parecem ter um destino post mortem diferenciado. No caso dos xamãs, dizem os Asuriní que seu ynga vai habitar para sempre o mundo de um dos espíritos entre os quais o pajé era iniciado. Em relação às tauyvas, conta Apebu que Mamari, falecida há cerca de dez anos, "foi para o fundo das águas do Xingu" em um poço profundo, local de morada dos Tauva, espírito feminino que se retirou do mundo dos vivos juntamente com as ariranhas e lontras depois que seu irmão (boakara) matou seu esposo, a anta ${ }^{79}$.

Para que o espectro do morto (dos xamãs, tauyvas e pessoas comuns) não importune seus familiares que ficam, é preciso que o pajé sonhe com ele e o "esconda" no mato. Segundo Apebu, as casinhas de barro onde moram os cupins (typykué), que vemos nos caminhos dos roçados e nos territórios de caça, são esconderijos de anhynga. Se o xamã não sonhar e direcionar o anhynga ao seu local adequado, o espectro do morto pode ficar para sempre rondando a aldeia dos vivos ou se abrigar nas capoeiras (kafera). Takamuin contou que roças velhas ou capoeiras são povoadas de anhynga.

\footnotetext{
78 Para se referirem às partes do corpo, os Asuriní, como outros povos ameríndios, colocam pronomes possessivos indicando seu possuidor (jeakynga , je = meu e akynga $=$ cabeça; gapa, ga = dele e $p a=$ mão, e assim por diante). Para falar das partes do corpo do morto utilizam o pronome possessivo "ga" (dele) na frente do substantivo. 0 sufixo era é um marcador de tempo pretérito, observado em diversas línguas tupi-guarani. Em Araweté, por exemplo, o marcador é pe ou we. Segundo Viveiros de Castro (1986, p. 495), os sufixos de pretérito marcam freqüentemente estados de separação (real ou lógica) como, por exemplo, as partes do corpo que recebem esse sufixo se pensadas fora de seu todo, e focalizam a relação entre o "estado puro" e a sua efetuação temporal. Assim, a cabeça do cadáver é akynguera (ga akynga = cabeça dele + era $=$ o que foi a cabeça dele), avera (ga ava= cabelo dele + era $=$ o que foi o cabelo dele), ga tamakynguera (ga tamakynga $=$ perna dele + era $=$ o que foi a perna dele), e assim por diante.

${ }^{79}$ Para uma narrativa completa da história de Tauva, ver Müller, 1993, p. 336, e, para uma descrição dos rituais Tauva, ver na mesma obra, p. 91-204.
} 
Em situações em que os anhynga insistem em importunar os vivos, os xamãs têm um papel importante na sua dispersão. A narrativa que transcrevo a seguir é um tipo de história contada para as crianças cotidianamente, como forma de instruí-las sobre os anhynga ${ }^{80}$.

Um homem falou para sua esposa: "vou buscar palha". Ele foi só no mato. Logo começou a tirar palha. Quando desceu viu um anhynga que disse: "Você tem que tratar meu filho que está doente". O homem ficou fraco e anhynga (do mato) o levou para a casa dele. 0 homem acordou, viu um bocado de anhynga; o olhos deles eram brancos. Anhynga falou para ele: "Sabe por que meu filho está passando mal? Porque comeu galinha do mato (arakuri eté)". Anhynga pediu para o homem, que era pajé, tratá-lo, mas o pajé falou: "Preciso ir lá em casa pegar meu cigarro (petyma) para fazer o tratamento". Chegando em casa, ele disse para a esposa: "Arruma tuas coisas que nós vamos embora, temos que voltar e ficar com todos na aldeia". A mulher passou urucum, óleo de jandy e queimou o mato. Foram para a aldeia, anhynga veio atrás. Pajé conversou muito com anhynga para ele deixar de ir atrás deles. Anhynga desistiu.

Na narrativa apresentada, o espectro anhynga pode ser caracterizado pela sua persistência, e, se o homem (esposo) não fosse um pajé, provavelmente teria sucumbido à sua força, deixando-se levar por ele, o que implicaria morte. A velha Burí explicou que o anhynga que perseguiu o pajé era, na verdade, da irmã falecida de sua esposa. Desde que perdeu a irmã, a esposa sentia muita tristeza e saudade, o que atraiu o espectro para perto do casal.

Em uma outra narrativa, a esposa pronuncia o nome do falecido, e não apenas o anhynga do marido volta como a leva para junto dele. Este espisódio é contado no mito do Kavara, reproduzido a seguir, em que anhynga aparece como os pedaços do corpo do inimigo morto, ocorrência semelhante à imagem do "corpo em pedaços" presente no mito do Apykwara, ao qual nos reportamos para falar da figura do tapy'yia (inimigo).

${ }^{80}$ Contada por Buri e traduzida por Matuia em outubro de 2012. 
Kavaryma ${ }^{81}$ é $a v a$ (humano). Ele e seu companheiro vão à mata e são atacados por um inimigo (tapy'ya). o companheiro morreu e Kavaryma, sobrevivente, voltou à aldeia. Neste retorno, foi perseguido pelo anhynga do companheiro: pedaços do corpo como fígado, coração, braço, perna, sangue. Kavaryma e os pedaços do morto chegam à aldeia e se realiza então, uma festa na qual cantam sobre o braço do morto. 0 sapo (kururu) é o kavaryva (função ritual) que canta, como Kavaryma. Cantam a noite toda e, de manhã, os anhynga vão embora. A esposa do morto fala seu nome. Por isso o anhynga dele volta e a leva com ele. Kavaryma fica. Hoje é Kavara ${ }^{82}$.

Braço, perna, fígado, coração e sangue são o anhynga do companheiro de Kavaryma que, insistentemente, o persegue até a aldeia. 0 que o afasta são os cantos sob o braço do morto. Como no mito, os Asuriní "cantam os mortos" para afastá-los definitivamente dos vivos durante as festas do Turé, e quem é investido nessa função são os cantadores chamados de kavaryva ("aqueles que animam Kavara"). O rito dos kavaryva encerra o ciclo de festas do Turé que incluem também a iniciação dos jovens, o toque das flautas turé, a celebração do milho, além da festa do Tauva associada à tauagem do guerreiro. Os kavaryva lideram um cortejo que culmina na casa grande (tavyve) onde estão as sepulturas dos mortos. Eles estão pintados de preto (pintura ajemo'ona) com penugem de gavião na cabeça, nos ombros, nas pernas e no $\operatorname{arco}^{83}$. Neste momento do ritual, os Asuriní choram sob a sepultura dos mortos dentro da tavyve para afastá-los definitivamente do mundo dos vivos.

A presença do anhynga é forte e seu perigo, maior no momento imediato após a morte da pessoa. Ouvi de alguns Asuirní que o risco permanece até que o corpo enterrado apodreça. Contrariamente, o ynga é veloz em alcançar seu destino, disse Apebu, que em alguns dias ele chega no caminho de Maíra.

Os espectros dos pajés parecem permanecer na terra por um tempo mais prolongado. Esta informação me foi fornecida durante expedição às aldeias antigas ao longo do igarapé Piranhaquara. Percorrendo a região ocupada pelos Asuriní algumas décadas antes do contato, encontramos vestígios de antigos

\footnotetext{
81 O sufixo yma indica a condição do ser no tempo mítico (Müller, 2013, p. 180)

82 Fonte: Müller, 2013, p. 179.

830 que sintetiza, segundo Müller, a dupla incorporação do matador/guerreiro e vítima/morto. Para a análise da figura (e figuração) de Kavara, ver Müller, 2013.
} 
aldeamentos: capoeiras, esteios de casas grandes e panelas de cerâmica. Nos deparamos com muitos cacos e muitas vasilhas de cerâmica praticamente intactas, o que era facilmente explicado por eles terem abandonado alguns aldeamentos sem poder levar seus pertences, ao fugir dos Kayapó. Panelas de cerâmica em locais identificados como cemitérios eram indícios de que xamãs teriam sido enterrados ali, pois, quando morrem, costumam colocar panelas em cima da cova para o pajé "vir tomar mingau", como explicou Takamuin. Nestes locais, mais de uma vez ouvi dos Asuriní que o espectro anhynga dos xamãs antigos estaria rondando.

Quanto aos ossos do morto, dos quais pouco falamos, são enterrados nas tavyves, casas comunais que, antigamente, podiam abrigar, não apenas as sepulturas, mas famílias extensas inteiras. Sobre este aspecto nos dedicamos a seguir.

Tavyve, vida e morte

Quando perguntei por que os Asuriní fazem a tavyve, Apebu me respondeu que, como gente viva, os mortos precisam de uma casa, referindo-se aos cemitérios (avytera) que ficam dentro da casa comunal. Explicação semelhante foi dada por Takiri, que liderou a realização da tavyve da aldeia Koatinemo em 2012. Ele disse que tomou a iniciativa por ter muitos parentes enterrados lá. Marakauá contou: "Asuriní morreu, aí enterra. Antigamente primeiro enterrava e depois fazia a casa grande. Um fazia casa e os filhos aprendiam. Asuriní fazia casa e chamava os outros para carregar pau: "Bora carregar esteio". Os outros ajudavam a carregar e a colocar o esteio, e também a cobrir de palha".

A casa grande é uma construção de forma abobadada com dimensões de cerca de 12 metros de altura, $10 \mathrm{~m}$ de largura e $30 \mathrm{~m}$ de comprimento, podendo ser comparada a um casulo, não havendo distinção entre o teto e as paredes. Sua planta é retangular e há quatro entradas, duas nas extremidades e duas laterais (Müller, 1993, p. 49). Com a sedentarização dos Asuriní pós-contato junto ao 
posto indígena da Funai, e com o advento da infraestrutura de educação e saúde construída na aldeia às margens do Xingu, a tavyve deixou de servir como habitação e passou a ser usada apenas como cemitério, além de abrigar ocasionalmente a realização de rituais diversos, como os Turé e os maraká.

Müller relata em sua etnografia (1993) que os Asuriní dizem que a construção de uma tavyve ocasiona o nascimento de novos membros do grupo e que a tavyve encontrada por ela, em 1976, havia sido construída após a morte de uma criança (Op. cit., p. 51).

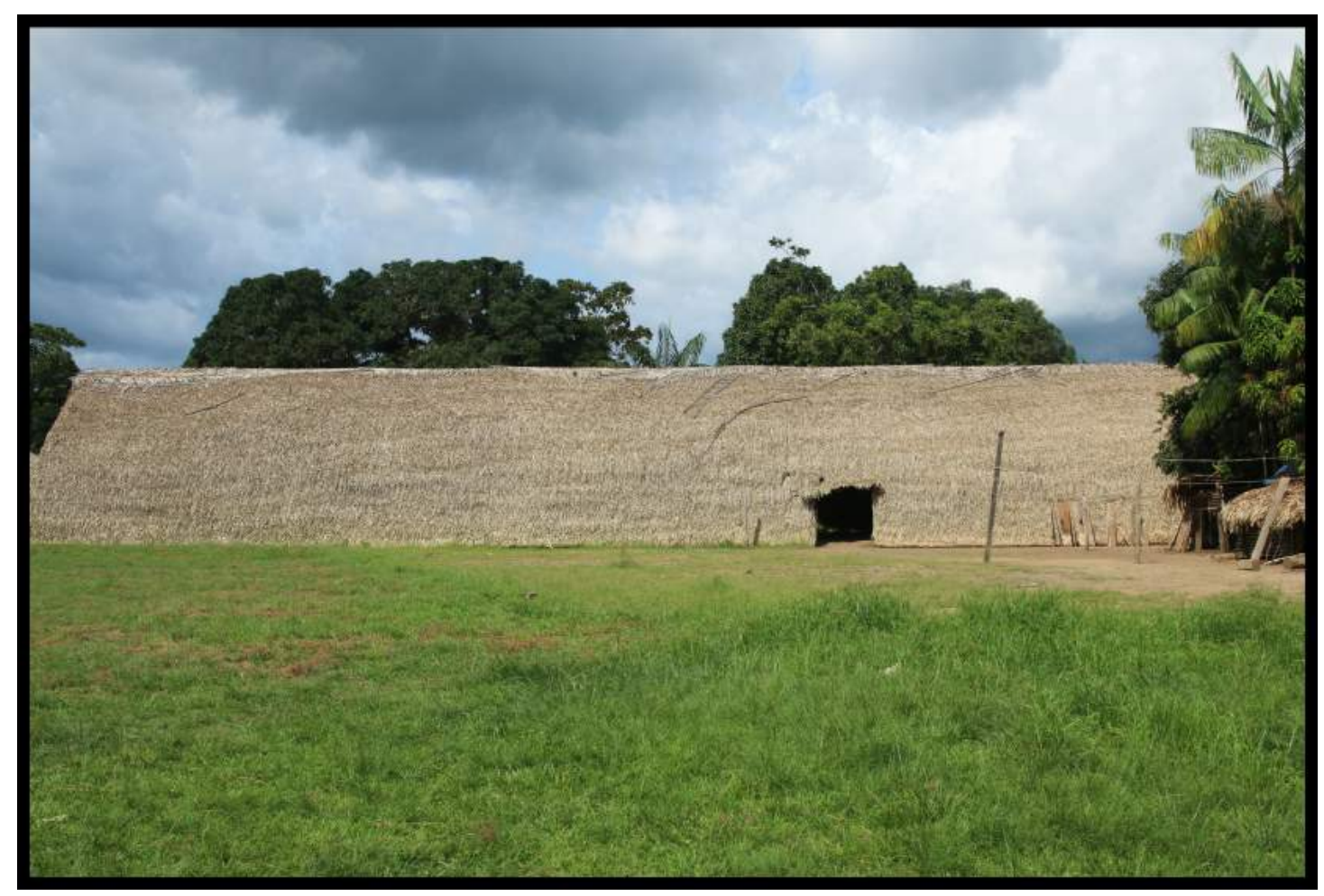

Imagem 2

Tavyve recém-construída na aldeia Koatinemo.

Foto: Alice Villela, 2012.

A tavyve tem uma conotação mágica. No momento de sua construção acontece o choro ritual quando o primeiro maço de palha (de palmeira babaçu) adentra a estrutura ${ }^{84}$. 0 momento chama-se pinambaia (pindava = palha e baia $=$ cobra) em referência ao maço de palha que tem a forma de uma cobra. Reportam-

${ }^{84}$ Os Asuriní se referem aos elementos da casa grande em analogia com o corpo humano; assim, a estrutura da casa é akynga, seus ossos, e a cobertura de palha, seu ava, cabelo. 
se ao primeiro maço de pindava a partir de analogias com o corpo de uma cobra: tem língua, cabeça, barriga e rabo, que apenas o pajé pode ver. 0 maço tem pouco mais de dez metros e, para carregá-lo até o centro da tavyve, são necessários mais de dez homens. Na tavyve construída em 2012, o maço foi amarrado a pouco menos de $1 \mathrm{~km}$ de distância da aldeia, perto da roça do Koati, e foram necessários mais de 15 homens para carregá-lo. Enquanto o maço é carregado, o "dono" da casa (tavyveijara, ijara $=$ dono $^{85}$ ) segura um charuto e entoa o canto tivagava. Quando o maço de folhas entra pela porta lateral da casa, os índios mais velhos fazem o choro ritual. Sentados em posição de cócoras com a cabeça apoiada entre os braços, choram sobre as sepulturas.

Müller interpreta o maço de palmeira de babaçu pinambaia como um símbolo fálico relacionado à Cobra - ser sobrenatural que ocupa lugar de destaque na cosmologia asuriní -, e a introdução da pinambaia na tavyve, em relação ao ato sexual, uma vez que os Asuriní associam a tavyve ao corpo humano e à procriação dos membros da aldeia (Müller, 1993, p. 53-54).

A construção da tavyve garante a geração da vida e o afastamento da morte. Uma aldeia não existe sem tavyve, ou seja, sem um local para abrigar a sepultura dos mortos. Um dos pontos que considero mais relevantes a esse respeito é que, mesmo diante de aceleradas transformações decorrentes dos mais de quarenta anos de convívio intenso com os brancos, a construção da casa comunal permanece sendo um aspecto central na vida asuriní. Em maio de 2015, assisti à substituição das residências asuriní de palha e taipa por casas de alvenaria de três cômodos e telhado de brasilit, custeadas pela Norte Energia, como parte das exigências feitas nos chamados "acordos de canteiro", negociações entre as lideranças indígenas e a Norte Energia, construtora do empreendimento hidrelétrico de Belo Monte. Em meio à presença de equipes da obra, caminhões, muita areia e cimento, os índios da aldeia Ita'aka - que até então não contava com uma casa comunal - dedicavam-se a finalizar a construção da tavyve.

${ }^{85}$ Chamam também o dono da casa de parearyva. Este nome se refere à posição ritual dos anfitriões na ocasião do ritual do Turé, realizado ao término da construção da casa grande. No ritual, os pareara convidam os turyva (turé = flauta e yva = sufixo que indica investidura) para tocar flautas e, juntos, chorar seus mortos, tatuar seus guerreiros e iniciar os jovens (Müller, 1993, p. 92). 
A casa grande do Ita'aka foi construída após a morte de um bebê de seis meses, filho de Atyva e Taymyra, que veio a falecer em Altamira no fim de 2014. 0 dono da casa, homem que liderou sua construção, é o pai da criança falecida, que assumiu o trabalho nesta função pela primeira vez. 0 índio foi orientado por Apebu, que, embora resida na aldeia do Koatinemo, permaneceu em tempo integral se dedicando a ensinar Atyva a conduzir a construção.

As fotos apresentadas a seguir retratam o momento preciso em que os índios do Ita'aka tinham recém-terminado a tavyve (fotos 3 e 4) e os funcionários contratados pelo empreendimento trabalhavam na construção das residências de alvenaria asuriní. Nas fotos 5 e 6 da prancha podemos ver os dois tipos de habitação convivendo na nova aldeia. 0 mato ainda cobre o centro no local onde será o pátio pois, como os Asuriní ainda residiam na aldeia antiga, a cerca de 500 $\mathrm{m}$ da nova, ainda não haviam se mudado para o local. A foto 1 apresenta a cova onde foi enterrado o bebê falecido, evento que motivou a construção da tavyve. A sepultura, coberta com uma lona, também pode ser vista na foto 2 , que retrata com maior amplitude o interior da casa.

Como observadora do novo cenário da aldeia, não pude deixar de notar a discrepância e o contraste dos dois tipos de construção, embora acredite que, para os Asuriní, esta visão nada tenha de contrastante. Nas fotos 7 e 8 me esforçei em capturar os dois tipos de construção, seus materiais e texturas diferentes. Na foto 10, a visão registrada é a de quem olha para a lateral da aldeia de dentro da tavyve, e o que se vê são duas novas residências. A foto 9 parte da mesma perspectiva que a anterior mas pode-se ver, ao fundo, uma residência em palha, construída por Takamuin, que se mudou do Koatinemo para lá na ocasião da construção da tavyve.

De todo modo, ficou evidente para mim o lugar central que ocupa a tavyve na vida dos Asuriní, no processamento da morte e na relação com os mortos. É interessante que, nesta ocasião, os brancos tenham fornecido apoio financeiro para custear as diárias dos índios que se dedicaram ao trabalho e gasolina para expedições para buscar palha (pindava). Se, no contato, os brancos são tomados como tapy'yia, causadores de mortes (e a fotografia participa desta agência nociva), agora, os brancos atuam apoiando a construção da casa, ou seja, a 
manutenção do aparato asuriní que os liga e lhes permite se relacionar com os mortos. Claro, os brancos não deixam de ser tomados como figuras ambíguas; afinal, o apoio provém do projeto hidrelétrico, o mesmo que ameaçou os índios e foi expresso desta maneira nos depoimentos obtidos por Souza nos anos 1990. Portanto, permanece a ambigüidade no relacionamento com os akaraí, convivência amistosa e ameaçadora que se tornou necessária. 
prancha 1

Taryve da aldeia Ita'aka

Fotos: Alice Villela, 2015.
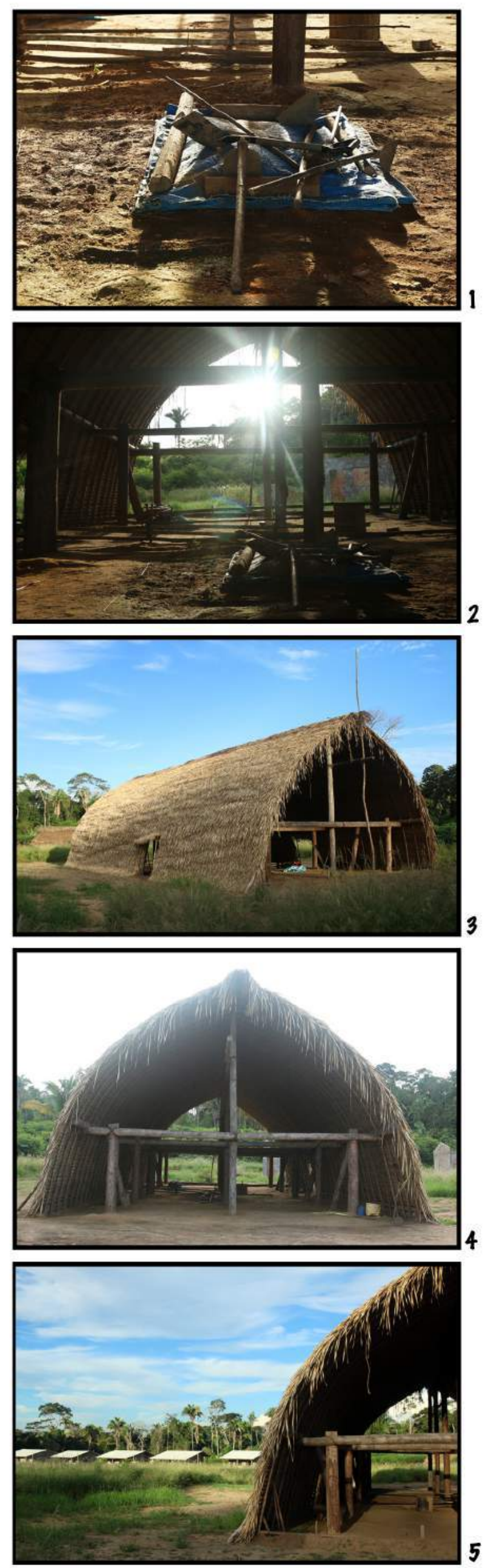

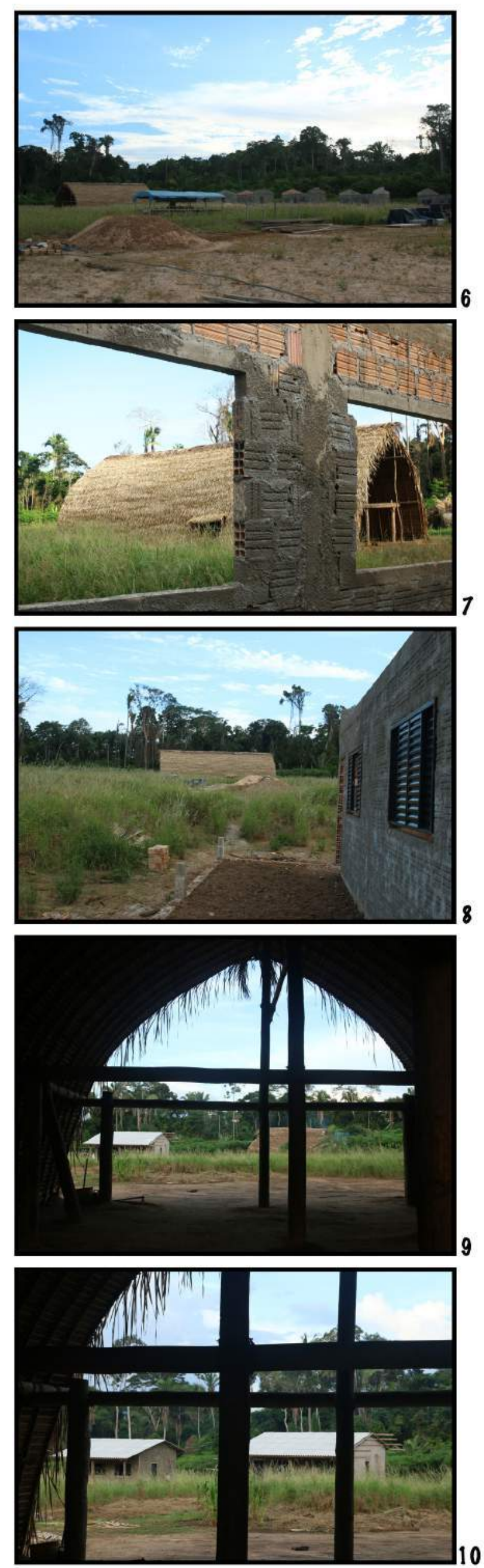


\section{CAPÍTULO 3}

\section{ENCONTROS E DESENCONTROS EM TORNO DA FOTOGRAFIA NO CONTATO}

\subsection{A fotografia no contato, um percurso de pensamento}

As reflexões iniciais a respeito da fotografia no contato da perspectiva asuriní se produziram em torno da sua ação patogênica, evidenciada nos relatos obtidos por intermédio da etnografia de Müller (2000) e em minha primeira ida ao campo para a pesquisa de doutorado em outubro de 2012. Foi apenas após desenvolver inúmeras considerações acerca da eficácia deletéria da fotografia ${ }^{86}$ que tomei contato com o livro Bearded indians of the tropical forest, de autoria do padre e etnólogo austríaco Anton Lukesch, publicado na Áustria pela Akademische Druck - u. Verlagsanstalt em 1976. O livro contém as fotografias tiradas por Lukesch, objeto dos relatos dos índios: 6487 imagens em cor e preto e branco, distribuídas nas 143 páginas em que o autor narra episódios da expedição que contatou os Asuriní nas margens do Ipiaçava, afluente do Xingu, além de apresentar descrições de aspectos da vida social asuriní elaboradas a partir de algumas semanas de convivência com os índios.

Informada pelos relatos acerca da patogenia da fotografia no contato, folheei o livro recém-obtido, curiosa pelas fotos, imaginando que veria retratos

\footnotetext{
${ }^{86}$ Sistematizadas em comunicações apresentadas em congressos e artigos. Ver "Quando a imagem é a pessoa ou a fotografia como objeto patogênico". In: Caiuby Novaes, Sylvia (org). Entre arte e ciência: a fotografia na antropologia. São Paulo: Edusp, 2015.

${ }^{87}$ Neste capítulo, reproduzi quase a totalidade das fotografias que retratam pessoas publicadas por Lukesch em sua obra. Excluí da análise cerca de dez imagens da publicação que retratam paisagens do Xingu, tapiris na mata e habitações asuriní (a exceção da tavyve da aldeia Taiuviaka retratada na prancha 1). Analiso as fotografias que estão no corpo do texto, e as imagens das pranchas servem para reforçar o que as do corpo do texto apresentam.
} 
de pessoas doentes, meios sorrisos e rostos de sofrimento esboçando o trauma do contato. A expectativa sobre o tipo de imagens que encontraria foi reforçada por alguns depoimentos que ouvi dos Asuriní em 2012, acerca de uma recente expedição aos locais dos aldeamentos pré e pós-contato ao longo do igarapé Ipiaçava. Durante a viagem realizada em 201088, diversos índios adoeceram e os xamãs tiveram pesadelos com os anhynga dos mortos, principalmente quando chegaram ao local da antiga aldeia Akapepugi, lugar onde os padres construíram seu acampamento, que se tornou o aldeamento onde os Asuriní permaneceram até 1972, quando foram definitivamente realocados para a aldeia do Koatinemo Velho, na margem direita do igarapé Ipiaçava. A memória traumática dos velhos indicou que os momentos iniciais foram carregados de tensões, dramas, mortes e adoecimentos. Eles lembraram também da ineficiência do trabalho da Funai que assumiu a "atração dos Asuriní" algumas semanas depois da partida dos padres. Foram registradas 13 mortes em pouco mais de um ano de contato, resultado da proliferação de epidemias de gripe e malária.

Qual não foi a minha surpresa quando, percorrendo o livro de Anton Lukesch, me dei conta de que nas fotografias dos padres não havia nenhum indício de sofrimento, doenças, trauma ou desastre cultural e populacional. Os índios, retratados em suas atividades - processando alimentos, pintando os corpos com jenipapo, voltando da roça, tocando a flauta do turé ou descansando na rede -, revelavam-se pelas imagens como se nada de muito extraordinário estivesse acontecendo; não são raras as ocasiões em que a câmera registrou pessoas à vontade, sorrindo em atitude posada para o fotógrafo. Há cenas que registram pequenas passagens e alguns episódios do encontro, por exemplo a distribuição dos presentes, ou quando Anton Lukesch experimenta um cigarro asuriní. No livro, a narrativa fotográfica reforça e atesta o que a construção textual sustenta: que o contato foi pacífico, que os Asuriní aceitaram de bom

\footnotetext{
${ }^{88} \mathrm{~A}$ expedição teve por finalidade efetuar pesquisa arqueológica colaborativa e foi viabilizada pelo Projeto "Território e História dos Asuriní do Xingu - Um estudo bibliográfico, documental, arqueológico e etnoarqueológico sobre a trajetória histórica dos Asurini do Xingu (século XIX aos dias atuais)", coordenado pela etnoarqueóloga Profa. Dra. Fabíola Andrea Silva, docente do MAE- Museu de Arqueologia e Etnologia da USP. O projeto teve apoio da Fapesp e foi realizado entre agosto de 2009 e julho de 2011.
} 
grado a presença dos padres e de sua equipe, e que a convivência com os novos interlocutores foi harmoniosa, amigável e cordial.

As fotos, que eu não me cansava de ver, não eram compatíveis com os relatos dos Asuriní sobre o desastre que foi o contato, nem também com a interpretação acerca da agência patogênica da fotografia. Seria preciso compreender melhor as fotografias da obra Bearded indians e passar a considerar a hipótese de que a relação dos Asuriní com a fotografia no contato não foi patogênica de imediato, ou melhor, não foi apenas patogênica. Como explicar índios tão à vontade, posando alegres ou simplesmente indiferentes diante do equipamento dos padres?

É sabido que os Asuriní, encurralados que estavam pelos inimigos Xikrin e Araweté de um lado, e pressionados pelos regionais que avançavam em seu território de outro, não viram alternativa a não ser estabelecer o contato com os akaraí. Na década de 1970, intensificou-se a presença dos brancos com a finalidade de contatar os grupos indígenas da região, decorrente do surgimento de novas atividades econômicas: mineração, agropecuária e projetos do governo, em especial a construção da rodovia Transamazônica (BR-230). Anton Lukesch, ligado à Prelazia do Xingu, aceitou liderar a expedição e empreender a "pacificação" dos "silvícolas" do Ipiaçava, a fim de evitar trágicos e belicosos confrontos entre índios até então isolados e colonos regionais. A expedição foi financiada pelo Consórcio Meridional, estabelecido entre a United States Steel, siderúrgica estadunidense, e a Cia. Vale do Rio Doce, que estavam interessadas na extensão da província ferrífera dos Carajás até a margem direita do Xingu.

0 relato de Manduka, publicado por Müller (2000, p. 184), revela que o primeiro encontro com a fotografia (e também com o gravador) foi marcado pelo medo; o índio diz: "Antigamente quando encontraram com branco ficaram com medo de gravador e fotografia [...]. Os mais velhos tinham medo. Eles tinham muito medo mesmo". Depois que os "antigos" - Asuriní do passado, que já morreram - viram que não morriam por conta desses equipamentos, teriam perdido o medo. Manduka explicita a mudança de atitude em relação ao uso de equipamentos de registro de imagem e de som; ele diz que a fotografia causou mortes, mas agora não causa mais, agora eles gostam. As imagens - e aqui ele 
inclui o vídeo - podem ajudar a "passar o conhecimento entre gerações", para que as crianças possam vê-los, após sua morte, "como faziam festa". Ora, discursos como o de Manduka, com avaliação positiva da produção de imagens, não invalidam as primeiras suspeitas dos índios em relação ao perigo da câmera nem a atribuição de agência nociva à fotografia, que causava adoecimentos e mortes. Afinal, o próprio índio não deixa de remarcar que, quando o padre Antônio encontrou-se com eles e tirou fotografia, "[...] homem morreu, não agüentou". Do que apreendo que não se trata de dizer que os "antigos" estavam equivocados em relação à sua interpretação e que agora sabem que nada têm a temer, mas de afirmar que no passado a fotografia matou e gerou doenças, mas agora, não, agora ela não mata mais, ou melhor, não está matando mais, e pode ser utilizada de maneira produtiva.

Se a desconfiança em relação ao que a fotografia pode causar estava presente no primeiro contato, as mortes e adoecimentos decorrentes do encontro com os brancos apenas confirmaram as suposições iniciais de que a fotografia podia agir de maneira deletéria e negativa. É apenas a posteriori que o discurso surge, como uma interpretação sobre um evento do passado. Caso o contato oficial com a sociedade nacional não tivesse sido o desastre que foi, muito possivelmente eles teriam menos motivos para desconfiar da fotografia, o que não implicaria, creio, uma ausência total de suspeitas, já que, subjugada à agência dos brancos, não faltavam, e não faltam, motivos para duvidarem.

Não se trata, aqui, de provar que, da perspectiva asuriní, a fotografia foi, de fato, a responsável pelas mortes e adoecimentos pós-contato. Os Asuriní deixam bem claro que as epidemias de gripe, tuberculose, malária e febre, sem falar na diarréia que acometeu muitos deles, causada pela ingestão excessiva de café, somada à falta de assistência, foram as principais responsáveis pelas mortes. Os relatos sobre a fotografia surgiram quando provocados, fosse por Regina Müller em 1997, quando realizou uma pesquisa sobre imagem, representação e transmissão dos saberes entre os Asuriní, fosse por mim, quando questionei os índios a esse respeito em trabalho de campo. O que nos interessa é perceber por que, acerca da fotografia, são estas as narrativas que emergem e como mudam ao longo do tempo. 
Esta breve digressão nos permite situar o leitor a respeito das diferentes interpretações e agências que a fotografia adquiriu entre os Asuriní, o que nos auxilia, inclusive, a compreender as suas primeiras reações diante da câmera dos padres - que as próprias imagens do livro Bearded indians... testemunham (ao mesmo tempo em que constróem) - o discurso que é presente até hoje em relação a sua agência patogênica, como interpretação a posteriori do desastroso contato, e a positividade com a qual é investida a partir da década de 1990, marca que permanece até hoje. A circulação das fotos de Anton Lukesch na aldeia em maio e junho de 2015 reforçaram o polo da positividade, mas de maneira diferente do que foi observado nos anos 1990. As fotografias evocaram lembranças dos parentes retratados e trouxeram seus nomes, o que foi vivido de forma agradável principalmente pelos Asuriní com mais de 60 anos que se recordam bem da chegada dos padres. Além disso, com as fotografias vieram as memórias do contato, e, embora se tratem de acontecimentos carregados de tensões e dramas, já se encontram recuados no tempo, o que lhes permitiu lançar novos olhares ao que aconteceu. No caso da fotografia, este movimento de produção de novos entendimentos em relação aos eventos do passado foi exemplar, o que resultou em novas formulações e camadas a serem agregadas à nossa análise.

0 trabalho de tentar entender as fotografias publicadas por Lukesch em contraposição aos relatos dos Asuriní me levou a um mergulho na publicação do padre-etnólogo. A partir daí, julguei interessante incorporar, de forma comparativa, a presença das fotografias no projeto documental e científico de Lukesch em contraposição à sua agência entre os Asuriní. Lukesch apresenta uma crônica da expedição que contatou os índios do Ipiaçava que é ilustrada pelas fotografias; relatos sobre o contato também foram produzidos pelos Asuriní, ao verem as fotografias. Metacomentários a respeito das fotografias entre os Asuriní são produzidos por Lukesch, ao ver e comentar uma das imagens de uma índia fazendo pose para o fotógrafo; e, do lado Asuriní, ao verem as fotos, também produziram reflexões sobre a presença da fotografia no contato. As mesmas imagens podem ser utilizadas e agir de modos muito diferentes, a depender do contexto e do projeto a que servem. 
O clímax em relação a diferentes maneiras de apreender as imagens emerge no momento em que comentamos as legendas das fotos de Lukesch em contraposição aos enunciados (nomes próprios) produzidos entre os Asuriní. Se, para o padre-etnólogo, a fotografia evidencia e documenta, as legendas auxiliam a descrever o que o leitor observa, por vezes fornecendo informações adicionais. Os Asuriní se interessam pela identificação dos parentes e, com seus nomes, trazem suas memórias. Se no primeiro caso a fotografia permite conhecer o que é exótico, no segundo ela engendra um processo de reconhecimento do referente que é um parente morto. No entanto, embora pese o aspecto positivo da circulação das fotografias entre os Asuriní, veremos que os polos perigo/positividade permanecem o tempo todo presentes e, a depender do contexto, da situação e do interlocutor, pende mais para um lado ou mais para outro, mas não raro os polos aparecem juntos, cobrindo a fotografia com o véu da ambigüidade.

Antes de partir para as narrativas acerca do contato de padres e índios, apresento o livro de Lukesch a fim de situar o leitor no projeto deste padre que era também etnólogo e fotógrafo, ainda que amador.

Bearded Indians..., o livro

É o maior sonho de todo etnólogo descobrir e fazer contato amistoso com uma das poucas sociedades isoladas e inaculturadas que ainda sobrevivem no mundo moderno, e estudar, entender e dar a conhecer o seu estilo de vida indígena [aboriginal] (Luckesh, 1976, p. 9) ${ }^{89}$.

O livro Bearded indians of the tropical forest é uma referência importante pois torna conhecida a existência de um povo cuja presença se confirmava apenas pelos relatos dos gateiros (caçadores de onça e gato-do-mato), ribeirinhos e colonos que perambulavam nas chamadas "terras dos Asuriní", região entre o Rio Xingu e seu tributário, o Bacajá. Outras notícias dos Asuriní aparecem em publicações de viajantes e etnólogos como Coudreau (1977

\footnotetext{
${ }^{89}$ Todas as traduções da obra de Anton Lukesch presentes neste capítulo são de minha autoria.
} 
[1897]), que teria percorrido o rio Xingu em 1896, e Nimuendajú (1948), que teria informações a respeito dos Asuriní a partir de outros índios. Lukesch (1976, p. 11 e 12) relata que Nimuendajú conheceu uma missionária inglesa que teria conversado com uma índia Guajajara (tupi), que, por sua vez, conversou com uma jovem mulher Asuriní que vivia como cativa entre os Kayapó do Gorotire; a índia Guajajara e a Asuriní puderam se entender, do que Nimuendajú conclui que a língua dos Asuriní pertence ao grupo tupi.

O padre-etnólogo Anton Lukesch documenta o primeiro encontro ou, como ele diz, a "descoberta" dos "silvícolas" que viviam em isolamento, sem contato com a "civilização". As fotografias funcionam como evidências de que o contato se realizou com sucesso, de forma pacífica e harmoniosa, e que os índios aceitaram com naturalidade e polidez os novos interlocutores. 0 texto a todo tempo faz referência às fotografias que ilustram e comprovam o que o autor afirma.

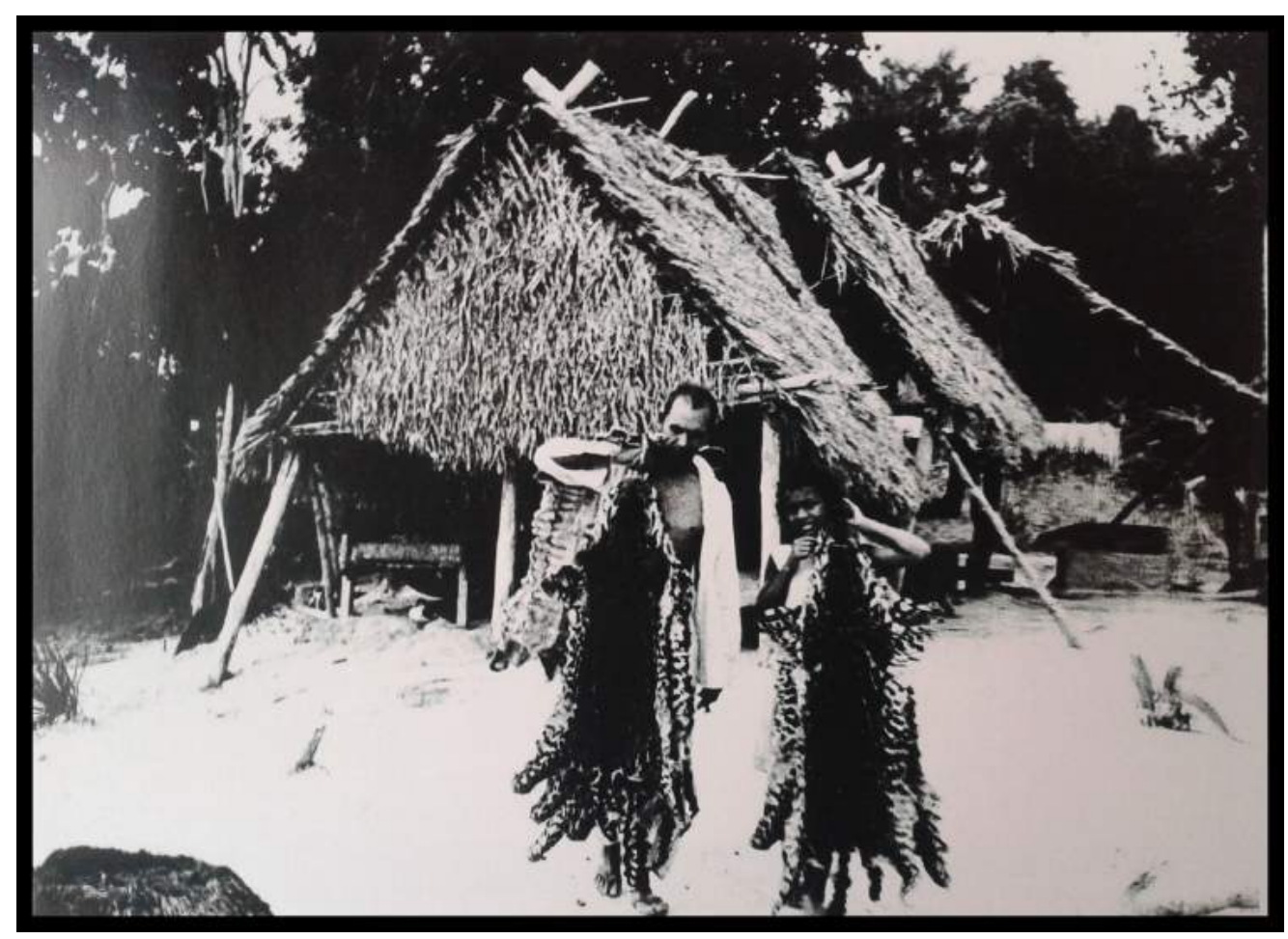

Imagem 1

"Colonos neo-brasileiros da floresta com peles de onça retiradas na terra indígena; Terra dos Asuriní". Foto e legenda de A. Lukesch, 1976, p. 28. 
O livro se divide em duas partes. Na primeira, Anton Luckesh relata como, depois de uma expedição penosa e das primeiras horas dramáticas do encontro, estabeleceu-se o contato pacífico com os índios do rio Ipiaçava. Ainda no início da obra, o autor fornece também um resumo histórico da presença dos Asuriní na literatura etnológica, um resumo lingüístico para fins de identificação tribal como Tupi e Asuriní, além de suas impressões pessoais sobre o grupo a respeito do seu aspecto físico e fenotípico. Nos tópicos seguintes, são apresentadas as principais notas de campo abordando diferentes aspectos da vida diária dos Asuriní tais como cultura material, objetos rituais, danças e músicas, casas e habitações, roças, caminhos e expedições realizadas, práticas de cura de doenças, divisão do trabalho, dentre outros. Embora a obra tenha pretensão etnográfica, o próprio autor reconhece que a permanência curta entre os Asuriní e o fato de serem monolingües não lhe possibilitou ir muito longe no estudo dos níveis "social" e "ideológico", tendo ficado no que chamou de "situação cultural em nível adaptativo" e nas indicações de "aproximação e aculturação à civilização" (Lukesch, 1976, p.126) .

É no final do livro que as "tendências em direção à aculturação" são exploradas. 0 autor trata da incorporação, pelos índios recém-contatados, dos objetos, oferecidos pelos brancos, tais como facas, facões, machados, miçangas e roupas, além do tabaco regional. Ao fim, no tópico de título "Primeiro contato e antropologia aplicada", Luckesh elucida as orientações que o guiaram nas atitudes, suas e de sua equipe, no primeiro contato (seleção de presentes é uma delas), e fornece alguns apontamentos em relação à continuidade da assistência à saúde e "manutenção da cultura".

O livro não nos interessa em seu aspecto etnológico. As discussões que o autor empreende circunscrevem-se ao campo da etnologia da época (anos 1960 70), em que a ideia de que os índios iriam se integrar às sociedades civilizadas e desaparecer era corrente, o que é bem expresso no conceito de "aculturação", utilizado também por Wagley \& Galvão em estudo sobre as Tenetehara (1949) a que Lukesch se refere ${ }^{90}$. Além disso, pude observar uma sutil projeção idealizada

\footnotetext{
90 Outras referências citadas pelo autor nesta linhagem de estudos: Galvão, 1960; Laraia \& Da Mata, 1967; Ribeiro, 1967.
} 
de que os índios recém-"descobertos", longe de corresponderem aos relatos dos mateiros como selvagens, violentos e hostis, teriam comportamentos contrários, regidos por valores como generosidade, bondade, harmonia e amor. Ora, muito embora algumas de suas impressões coincidam com as minhas próprias a partir da convivência com os Asuriní - de fato, eles são extremamente amigáveis, amáveis e cativantes (e também delicados, de comportamento sofisticado e comedidos) -, desconfio que os valores observados e o exagero idealizado provenha do fato de Lukesch ser, antes de tudo, um missionário.

Mas justamente, na limitação da obra reside o valor maior da publicação para o tipo de reflexão que pretendo produzir. É no fato de ter ficado na "situação cultural adaptativa" - ao se demorar nos comentários a respeito da incorporação de objetos dos "civilizados", e de o autor ter dedicado muitas páginas a descrever a expedição e o encontro com os "índios barbados" - que a narrativa textual do livro, e não apenas as fotografias, ganham projeção para a reflexão em curso. Isso porque as impressões pessoais de Lukesch e as atitudes e reações dos Asuriní neste primeiro momento de relação com os brancos nos dizem muito a respeito da relação dos índios com as fotografias, e nos permitem compreender melhor as imagens presentes na publicação.

\subsection{Crônicas do encontro}

A narrativa da expedição que contatou os Asuriní do Ipiaçava é apresentada por Lukesch logo no início do livro. 0 relato se organiza à maneira de um diário de viagem e explicita os principais eventos, ações e sensações do autor e de sua equipe durante a expedição que partiu ao encontro dos índios. Exatos 44 anos depois, os Asuriní das aldeias Ita'aka e Koatinemo são colocados em confronto com as fotografias do padre-etnólogo e, nesta ocasião, as imagens agem como um dispositivo que permite que alguns índios rememorem e relatem o episódio do encontro com os padres. É sobre as narrativas acerca do primeiro contato que esta seção se debruça. Passemos à crônica do encontro da perspectiva do padre-etnólogo e, depois, à versão asuriní. 
O primeiro encontro com os índios barbados ${ }^{91}$

Abril de 1971. Os irmãos Anton e Karl Lukesch e mais seis homens, entre os quais "mateiros" que conheciam bem aquela região da floresta amazônica, reuniram-se na pequena cidade de São Felix (PA), na foz do rio Fresco, no Xingu, para organizar os últimos preparativos para a expedição em busca dos índios do Ipiaçava. Entre os equipamentos levados na bagagem estavam ferramentas para a construção de um barracão, encerados, objetos de utensílio para a rotina no acampamento, medicamentos de primeiros socorros e muitos presentes para os índios.

Cícero Maia, o patrão de muitos caçadores (provavelmente de gatos-domato e onça) daquelas imediações informou aos padres a respeito do movimento dos grupos indígenas na margem direita do Xingu. No dia 15 de abril Karl e Anton Lukesch sobrevoaram a região e, embora não tenham avistado índios, puderam ver uma aldeia pequena ao lado de uma roça e uma aldeia grande com uma "maloca" comprida em construção perto do igarapé Ipiaçava. 0 experiente piloto registrou a posição exata das aldeias em um mapa e, de posse dessa orientação, eles iniciaram a expedição. Foi acertado que o piloto faria sobrevoos semanais na região registrada para prestar auxílio, caso a equipe necessitasse de ajuda.

Foram necessários cinco dias de viagem de motor de popa descendo o Xingu, saindo de São Felix, até chegar à foz do Ipiaçava; de lá subiram cerca de 50 km pelo igarapé. Dia 21 de abril, tendo chegado ao ponto registrado no mapa, o grupo decidiu abrir uma clareira na densa floresta para fazer o acampamento na margem direita do Ipiaçava. Aos mateiros era permitido pescar e caçar apenas nas imediações do acampamento, para não assustar os índios com o barulho dos disparos. No terceiro dia de permanência no acampamento começaram a fazer expedições em pequenos grupos, mas, logo depois das primeiras tentativas, a procura das aldeias indígenas na densa floresta se tornou extremamente

\footnotetext{
${ }^{91}$ Reproduzo de forma sucinta o relato que consta no tópico "Estabelecimento do contato", inserindo aspas nos termos, expressões ou passagens que extraí por inteiro do texto. Ver Lukesch, 1976, p. 15-19.
} 
dificultosa, e a chuva diária e torrencial tornava os esforços ainda mais árduos. Apesar dos obstáculos, em pouco tempo passaram a encontrar indícios de ocupação humana na mata: trilhas e tapiris - pequenas cabanas feitas em palha.

Mapa - Assentamentos indígenas Asuriní do Ipiaçava em 1971

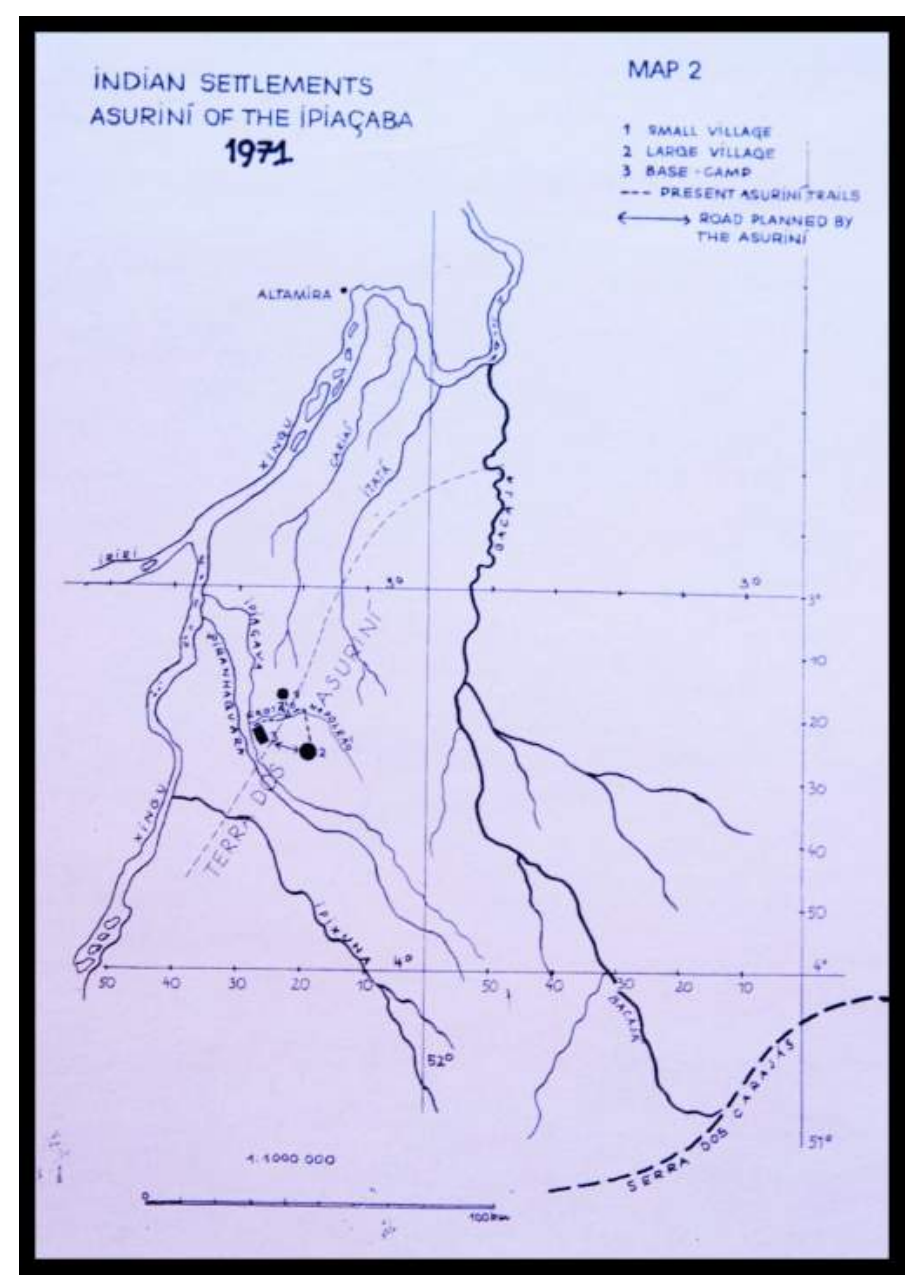

Fonte: Bearded Indians of the tropical forest, p. 128.

No dia 28 de abril os mateiros viram três índios em uma roça situada a dois dias de caminhada do acampamento em que estavam, e então os irmãos Lukesch e mais quatro dos seus seis homens se prepararam para uma grande expedição; apenas dois homens permaneceram no acampamento. 


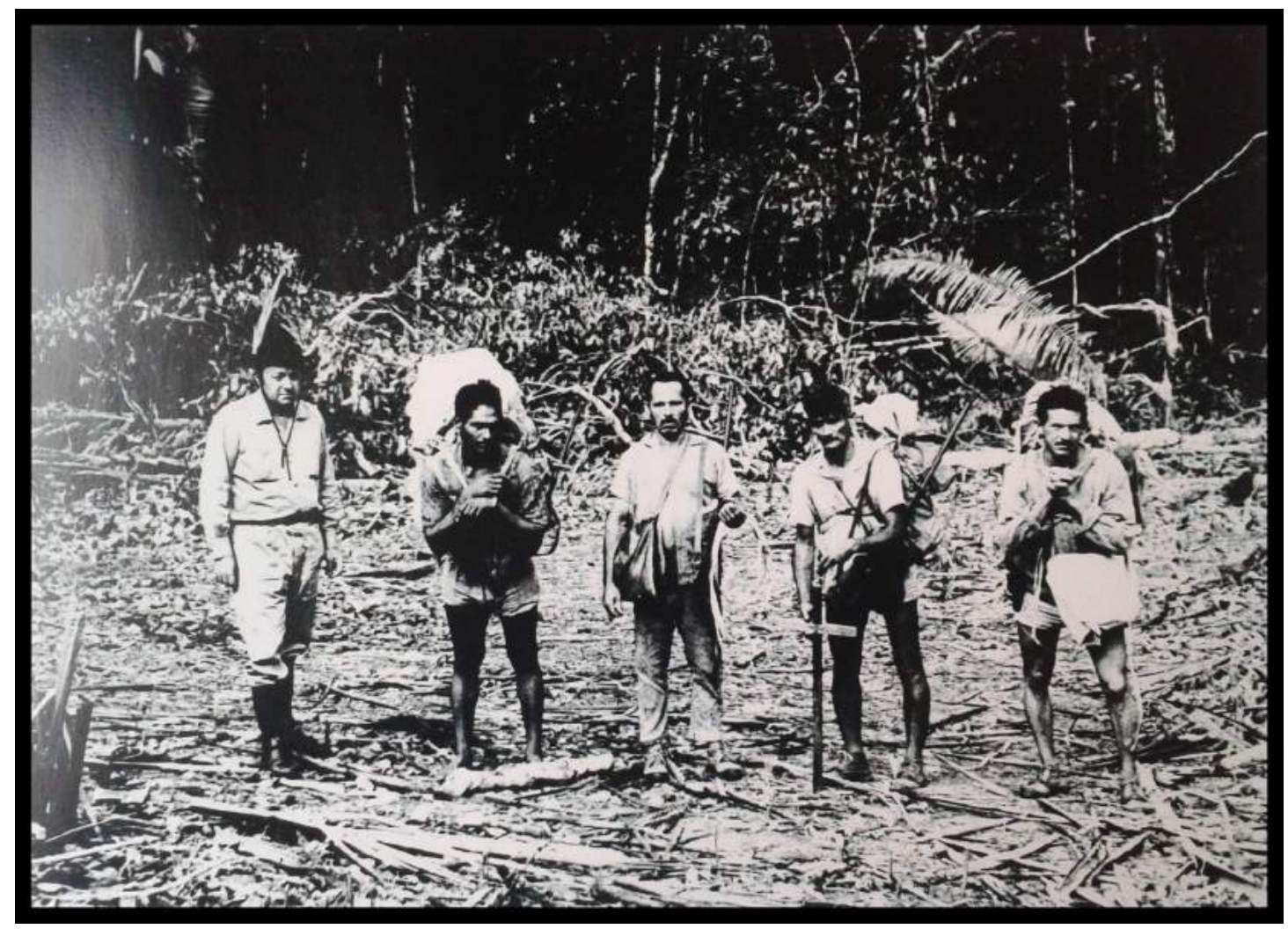

Imagem 2

"Início da expedição por terra com o Pai Karl".

Foto e legenda de A. Lukesch, 1976, p. 29.

Dia 8 de maio, por volta das $17 \mathrm{~h} 30$, encontraram uma trilha que parecia estar razoavelmente fresca, e então a seguiram a passos apertados, "entusiasmados com a descoberta" e, finalmente, no dia 9 de maio, ao meio-dia, observaram, a cerca de 50 metros de distância, várias cabanas de uma pequena aldeia.

Logo na entrada, um velho imponente se levantou; ao seu lado havia um feixe com muitas flechas, e eles podiam ouvir ruídos de agitação vindos da aldeia. 0 velho fez gestos frenéticos, o que para os irmãos Lukesch tornou imperativamente claro que deveriam seguir adiante; então, apenas os padres avançaram. Logo um homem alto e forte, de cerca de 30 anos, apareceu e tomou o lugar do velho - apenas mais tarde eles vieram saber que este homem era um dos chefes da aldeia. Este índio se dirigiu aos padres apontando o arco de forma ameaçadora. Anton pediu aos membros da sua equipe que deixassem as armas no chão e em seguida arriscou todas as palavras que conhecia nos idiomas indígenas que tinha estudado (tupi clássico, suruí e até kayapó), tudo para fazer 
aquele homem entender que eles tinham vindo como "amigos". Para reforçar sua intensão, ele esticou os braços e ofereceu alguns presentes: facões, machados e miçangas. Agora eles estavam completamente rodeados de índios e o homem jovem que os abordou não mudava sua atitude dura e hostil. Anton ofereceu dois facões a ele, o índio aceitou e a tensão começou a diminuir. 0 "cacique" levou, então, Anton à sua cabana e o pai Karl trouxe mais presentes. Os irmãos chamaram o restante da sua equipe e os índios também partiram para chamar os outros Asuriní que estavam por perto, em roças ou acampamentos na mata.

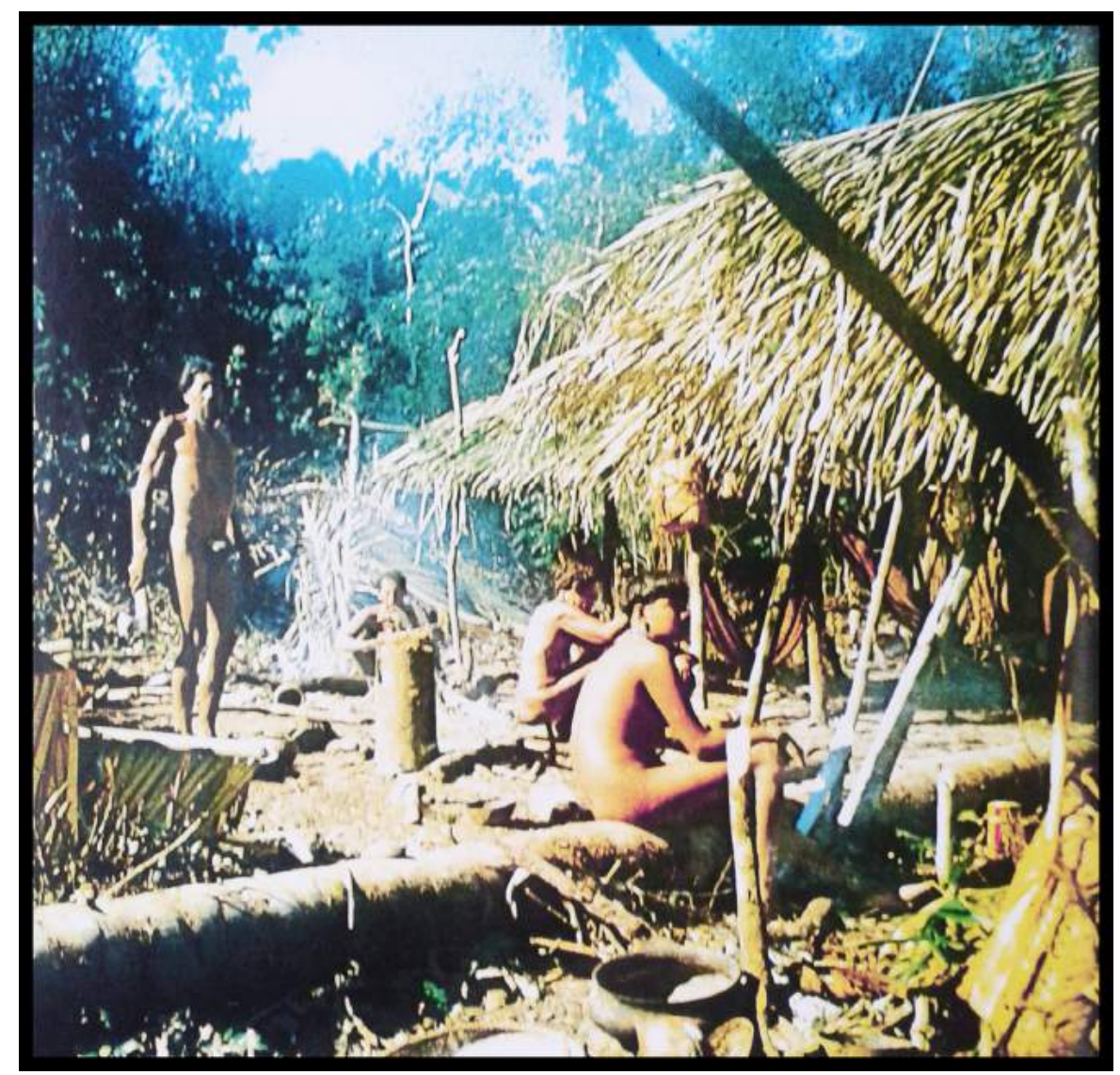

Imagem 3

"Acampamento asuriní na floresta na margem direita do Rio Xingu".

Foto e legenda de A. Lukesch 1976, p. 26. Esta imagem está na capa do livro.

Naquela noite os irmãos Karl e Anton armaram suas redes embaixo de um tapiri anexo a uma das maiores habitações da aldeia. A jornada havia terminado, eles cumpriram a missão, encontraram os índios e a tensão inicial deu lugar a uma "virada de sorte"; agora, Anton já começava a observar e a notar os "primeiros vislumbres do comportamento geral dos índios". Uma vez aceito o 
contato, os índios trataram os padres e seus homens com afabilidade e cordialidade, oferecendo comida; algumas famílias separaram para os novos interlocutores "seletas delícias" que os padres e sua equipe consumiram com gosto.

Dois dias depois do contato realizado, os índios levaram o grupo de brancos à grande aldeia, onde foram recebidos de forma calorosa: os Asuriní ofereceram muita comida e suas próprias redes de dormir para a equipe pernoitar. No total, Anton Lukesch afirma ter tido contato pessoal com 78 índios: 30 homens e 41 mulheres, três meninos e quatro meninas. Na segunda metade de sua permanência, aproximadamente duas semanas depois do primeiro encontro, cerca de 30 índios saíram definitivamente de suas aldeias e acompanharam os padres com a intenção de fixar residência no acampamento dos brancos. Após algumas semanas, o grupo liderado pelos padres partiu definitivamente e os índios ficaram aguardando novos akaraí. Poucas semanas depois chegaria ao novo acampamento - que mais tarde foi denominado Akapepugi - uma equipe da Funai, liderada pelo sertanista Antônio Cotrim Soares, com o intuito de assumir a "atração" e prestar assistência ao grupo recém-contatado. Um novo capítulo na história da relação com os brancos teria início. 


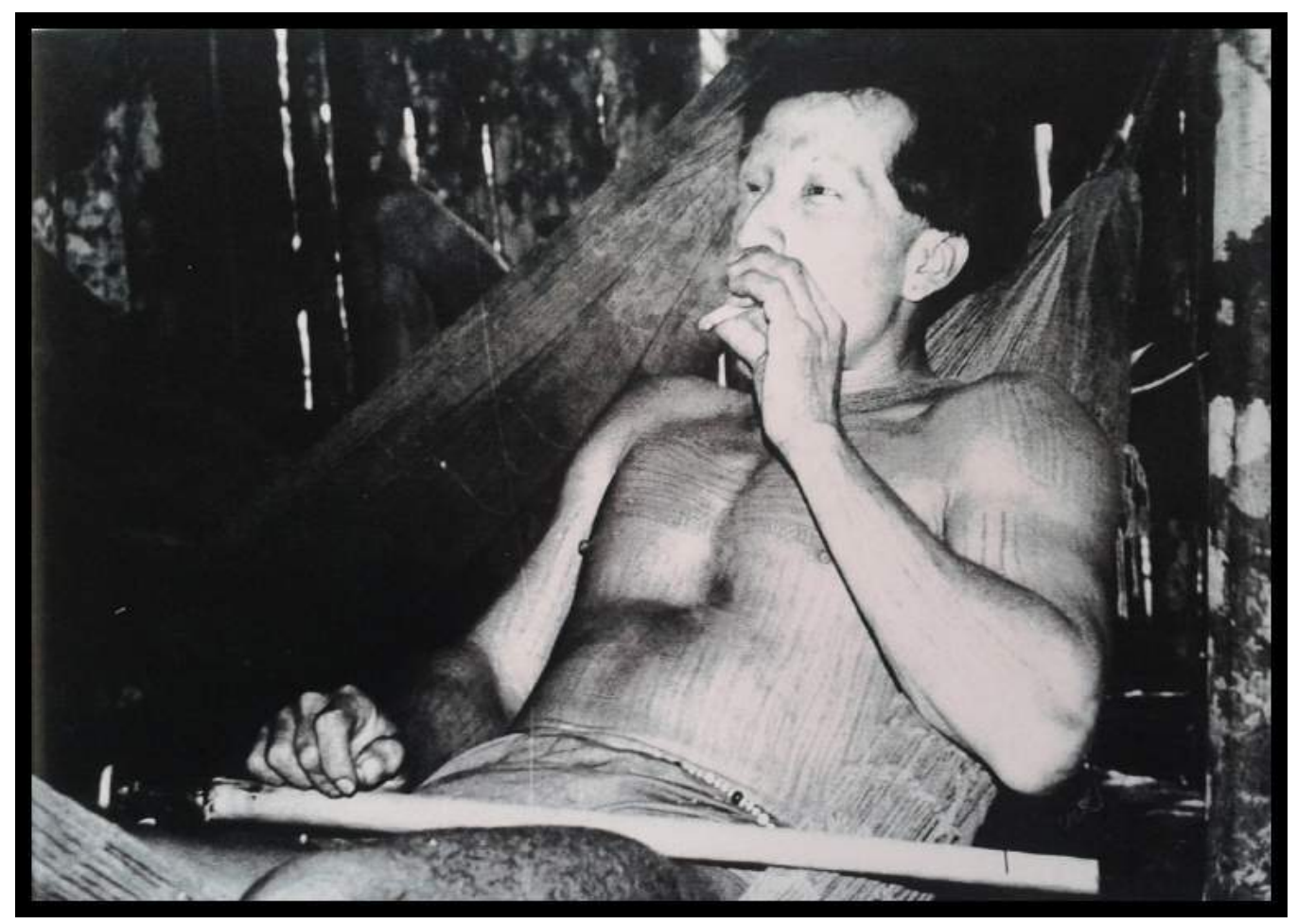

Imagem 4

"Líder do grupo experimentando o cigarro do Pai Karl".

Foto e legenda de A. Lukesch, 1976, p. 103.

A crônica do encontro com os tapy'yia (inimigos) - forma com que os Asuriní se referiram aos brancos no momento do contato ${ }^{93}$ - foi lembrada e contada por Marakauá, índia de 60 anos, mais de 40 anos depois do episódio

92 Emprego o termo utilizado pelos Asuriní na sua tradução para o português, não foi possível registrar o termo utilizado na língua. Viveiros de Castro comenta que os Araweté, assim como os Asuriní, procuraram o contato com os brancos e literalmente "pacificaram" os brancos, menos por se sentirem territorialmente encurralados e mais para fugirem às hostilidades de tribos inimigas (Viveiros de Castro, 1986, p. 136). Albert, na introdução do livro Pacificando o branco, cosmologias do contato no Norte-Amazônico, afirma que o tema da "pacificação/domesticação dos brancos" visa compreender a diversidade interna de representações que são, em verdade, dispositivos de domesticação simbólica e ritual da alteridade dos brancos e neutralização dos seus poderes nefastos. Albert comenta que o tema "índios amansam brancos" já havia sido evocado por Darcy Ribeiro e também por Rondon a propósito de diversos grupos indígenas, dentre os quais cita os Kaingang, Xokleng, Parintintin, Umutina, Kayapó e Rama-Rama. Ver Albert, 2000, p. 10.

${ }_{93}$ Embora, em seus relatos sobre o contato, os velhos tenham empregado o termo tapy'yia (inimigos) e não akaraí (brancos) para se referirem aos padres e sua equipe, a opção das tradutoras foi empregar o termo "brancos" e não "inimigos" na versão em português. 
ocorrido. Numa tarde quente de maio, enquanto via as imagens publicadas por Lukesch calmamente deitada em uma rede dentro de sua residência, a índia pegou a fotografia acima reproduzida e se manteve por alguns minutos em silêncio olhando fixamente para a imagem. Na foto, um índio forte, adulto maduro, com o peito e os braços tatuados, vestindo um short e usando um colar de cintura de miçanga (kapuava), sentado na rede tradicional asuriní (tupava) feita de algodão, fuma um cigarro enquanto concentra o seu olhar distante, como quem calcula, considera e reflete. Parece que há um cigarro comprido em seu colo, componente da imagem que nos permite conjecturar ser ele um pajé ou vanapy, ajudante do xamã e responsável pela feitura dos charutos (petym) rituais. A legenda da imagem na obra de Lukesch indica que o índio é o homem que líderou o primeiro encontro com os brancos, e foi quem se dirigiu aos padres apontando o arco de forma ameaçadora. Após se demorar olhando a imagem, Marakauá se lembrou da história deste primeiro encontro e quis contá-la.

A maioria dos índios que viram esta imagem não precisou de muito tempo de observação e contemplação para saber quem é a figura retratada; apenas uma olhadela e qualquer Asuriní que conviveu com este homem soube identificá-lo. Seu nome é Avona. Ele faleceu na atual aldeia do Koatinemo, é pai de Apyrakamy e foi esposo de Kuipiuna e de sua mãe, Maia, ambas falecidas. Também foi casado com Marakauá e com sua irmã, Moteri. Embora a memória da relação pessoal de Marakauá com Avona tenha vindo à tona com a fotografia, foi a memória do primeiro encontro com os brancos a lembrança privilegiadamente despertada. $\mathrm{A}$ mesma fotografia levou outro índio, Takamuin, de 65 anos, a rememorar os episódios do primeiro encontro com os padres. Ambos forneceram longos relatos na sua língua que foram traduzidos por Apyjava, Ipikiri e Matuia, mulheres de 20, 27 e 50 anos, respectivamente, que, pela proximidade com os narradores ou por já terem experiência no trabalho de tradução, foram as pessoas encarregadas pela versão que apresento. As tradutoras, algumas mais outras menos, emitiram seus comentários ao tentar fazer que eu compreendesse as narrativas dos velhos, e, dada a riqueza de algumas das suas explicações, passei a incorporá-las na versão dos relatos para o português. 
A vida dos Asuriní antes de maio de 1971 era muito difícil. Marakauá conta que Avona não agüentava mais ficar andando no mato, fugindo de tapy'yia e comendo maritá'ui (farinha de casca de côco de babaçu) porque não tinham como fazer roça. Depois de perder alguns de seus parentes (um tio e um irmão) em guerras intertribais com os Araweté, Avona, pajé forte que era, decidiu sonhar "para amansar" os inimigos. Marakauá conta: "Ele era bravo, ele dizia que ia amansar tapy'yia [inimigo, branco]. Ele perdeu parente dele aí ficava bravo e sonhava pra matar outro, sonhava que comia coração, fígado do outro, mandava criança adoecer de raiva. Pajé matava assim dia".

Takamuin guarda a memória da situação penosa em que viviam entre guerras, principalmente com os Araweté e Xikrin, e lembra em detalhes como Avona fez para amansar os brancos.

Araweté matava muito a gente. Alguém falou: "Bora tentar que eles não matem muito a gente". Porque eles estão matando tudinho nós mesmo e também tem outros inimigos [tapy'yia]. Quando a gente chega, aí que eles [Araweté] matam nós tudo. "Bora fazer roça". Nós fizemos roça no caminho deles [Araweté]. Nós fizemos várias casas. Outros fizeram casa. Tem que sonhar muito eles [com os brancos]. "Eu sonhei eles, eles estão lá ainda", disse o pajé [Avona], "hoje eles chegam". Ele sonhou como se estivesse vendo de verdade [aripeuarave gyresak, ele viu no claro].

"Bora, pode sair tudo de perto de mim", pajé falou. "Porque hoje eles vão chegar". Não sei como é que ele sonhou de verdade isso. Aí, Marakauá foi pegar batata com a mãe e com a vó dela [...]. "Pode ir tudinho", não sei o que vai acontecer comigo", pajé falou. Pajé sonhou e mandou mulher dele pegar macaxeira e batata pra dar pra os brancos. Ele [Avona] estava fazendo arco e flecha na porta, tipo de uma casa abandonada, era como uma clareira; fizeram limpeza no terreno pra ele. Pajé gritou: "cadê os brancos?". Porque ele sonhou e viu eles. Ele não tinha medo deles não [...]. Falou pros outros: "Pode ir que eu vou falar com eles, vou sonhar e amansar eles". E gritou para os brancos "Pode vir aqui falar comigo".

Os homens [brancos] chegaram na clareira. "Pode deixar arma de vocês", pajé falou. "Deixa a arma de vocês, eu não falei?". E cada um foi deixando. Só faltava o revólver da cintura de um deles, esse eles não queriam deixar. "Tem que deixar uma arma pra mim. Vem chegando, vem chegando. Pode chegar e sem fazer nenhuma maldade comigo". O que estava na frente foi e pegou na mão do pajé o outro que estava atrás só segurava os outros. Estavam cheios de bolsas nas costas com facão, miçanga. Cada um deles 
deu miçanga pro pajé. Cada um deu facão pra ele, pajé ficou com um monte de facão. Começaram a ir para trás, porque pajé mandou ficar longe dele. Naquele dia tinha muito branco. Pajé gritou pra parente dele: "Vai falar pra parente que eles não estão fazendo nada de ruim comigo. Pode falar pro pessoal que eu estou bem e é pra voltar rápido".

Segundo Marakauá, então esposa de Avona, o marido dela falava que um dia ia sonhar e amansar os inimigos brancos porque ele era "pajé de verdade". 0 modo como ele amansou foi sonhando (gapuau, ele sonhou) e ao sonhar, ele "viu no claro" (aripeuarave gyresak). A capacidade de viajar aos mundos dos espíritos, nos momentos do sono e durante os rituais xamanísticos, e também de ver os espectros dos mortos (anhynga) são todos referidos pelo verbo aesak, ver, habilidade que apenas o xamã possui ${ }^{94}$. A ênfase em "ver de verdade" se refere a esta aptidão especial em que ver o que nem todos vêem implica, também, a possibilidade de agir sobre o que se vê. Foi assim, sonhando e vendo (ou "sonhando vendo"), que Avona "amansou" os inimigos brancos.

Avona teria visto, agora como qualquer Asuriní, uma grande quantidade de miçanga e facão na beira do igarapé Ipiaçava, e já sabia se tratar de presentes trazidos pelos brancos para eles. Somente depois de ter sonhado e amansado os inimigos foi que os brancos apareceram na aldeia.

Apebu também se recorda de quando Avona amansou os brancos e explica95: "Porque outro índio ataca demais, então estava procurando quem é que tá manso para não morrer tudo". Questionado sobre o momento da chegada dos padres, ele diz: "Quando padre Antônio chegou eu estava roubando coisas dele na beira do Ipiaçava, eles tinham trazido uma caixa de facão e não acharam até hoje". Em seguida conta com mais detalhes:

\footnotetext{
94 Já comentamos no capítulo 1 a respeito dos sonhos do xamã a propósito das viagens que empreende seu duplo (ynga) nestas situações. Embora o xamanismo seja um tema de fundo, não nos cabe, neste trabalho, descrever e sistematizar a forma com que esta prática acessa diversos universos e realiza a tradução de mundos (Cf. Manuela Carneiro da Cunha, 1998). Para esse tipo de descrição sugiro consultarem Müller (1993), especialmente o capítulo 3 "Maraká, o ritual xamanístico", em que a autora aborda tanto os atos e papéis rituais quanto os princípios cosmológicos que fundamentam o xamanismo.

${ }^{95}$ Apebu concedeu seus relatos em português.
} 
Eles [os padres] fizeram um acampamento na beira do Ipiaçava. Tinha casa de palha. Fomos lá. Saímos cedo do Taiuviaka [aldeia antiga] para roubar farinha e facão de gateiro. Aí ficou de noite. Fizemos acampamento, achamos jabuti. Papai falou: "Vamos lá olhar o rio". Aí nós viemos pra beira e vimos uma clareira de roça. A gente veio. Já era tarde, seis horas. A gente veio e viu akaraí, só dois. Só tinha o cozinheiro e mais um. Vimos a casa novinha, tinham terminado de cobrir. Ficamos olhando até de noite. Aí alguém falou: "Amanhã cedo nós vamos pegar as coisas deles". Aí fomos dormir. Cedinho a gente tomou caldo de jabuti. Chegamos no escuro ainda. A gente ficou esperando eles saírem, estavam fazendo café. Eles saíram, foram pescar. A gente foi e roubou as coisas. Levamos machado, facão e enxada.

Boaiva relata que, quando os padres chegaram na Taiuviaka, eles estavam fazendo tavyva, ele era um dos responsáveis pela construção da casa porque seu irmão mais novo tinha acabado de falecer. "Tem formiga demais, taiuvi, formiga demais, por isso que chama Taiuviaka" (aka, casa e taiuvi, formiga). Marakauá lembra que a aldeia Taiuviaka não tinha roça grande, mas tinha akapepum, casa grande. Takamuin explicou que, para fundar uma aldeia nova, primeiro eles faziam uma roça grande, passavam a freqüentar a área e depois se mudavam. Quando a primeira pessoa falecia, faziam a casa grande para enterrá-la. Podiam, também, fazer a casa grande sem que ninguém falecesse; neste caso, levavam os ossos dos parentes enterrados em outra tavyve para a nova. No momento em que os padres chegaram havia apenas a aldeia Taiuviaka; os demais Asuriní residiam em acampamentos e tapiris na mata e na roça. Nas fotografias da prancha 1, apresentada a seguir, há fotos, feitas pelos padres, da casa grande em construção na aldeia Taiuviaka.

Depois que Avona amansou os brancos, outros parentes que estavam por perto do acampamento se apresentaram. Quando chegaram os outros Asuriní, os padres repetiram a estratégia e foram dividindo os presentes: machados, facas, facões e miçanga. Em seguida, chamaram os outros Asuriní que estavam no mato e na roça e só mais tarde foram à aldeia Taiuviaka avisar os demais. A aldeia ficava a cerca de três a quatro quilômetros da beira do Ipiaçava. 
prancha 1

Tavyve em

construgão na aldeia Taiuviaka
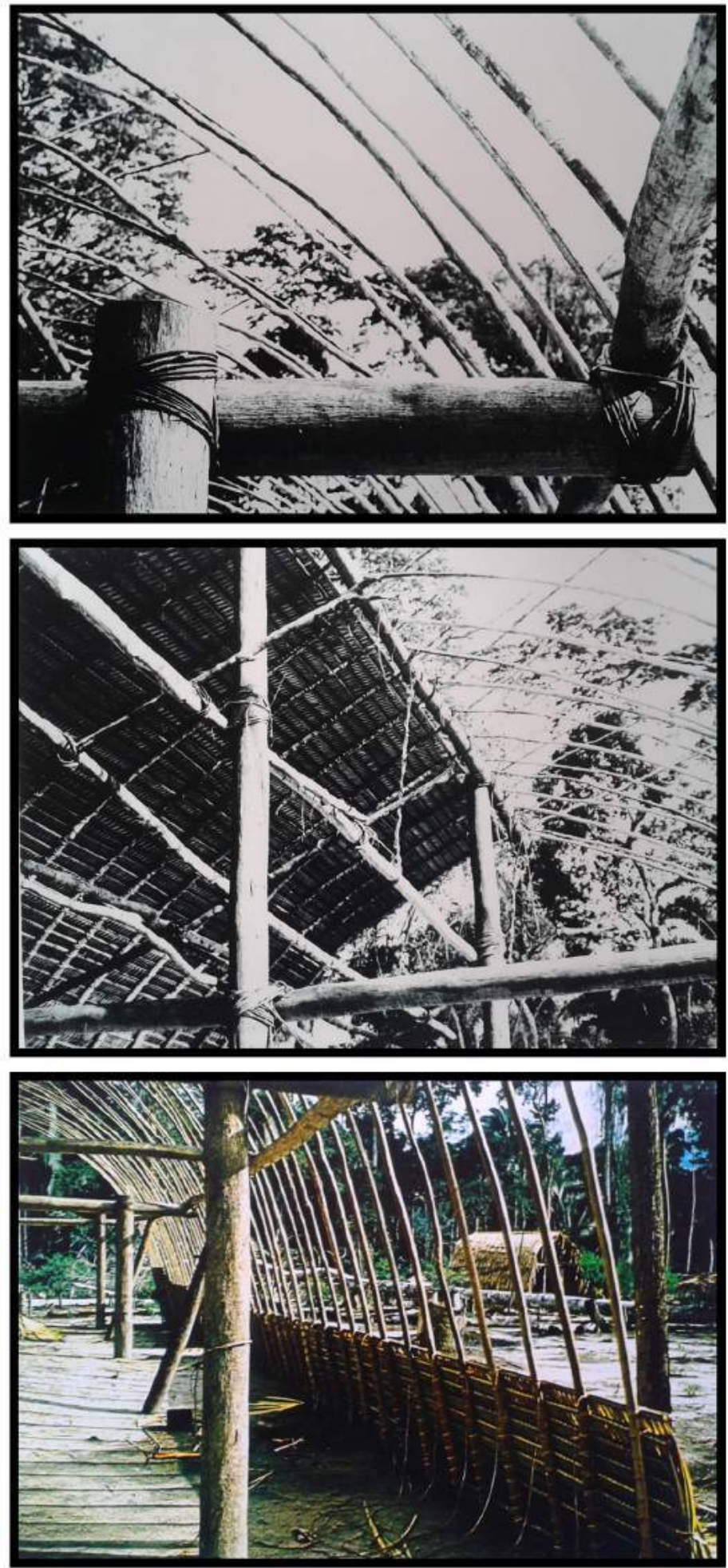

Nesta prancha, detalhes da estrutura, amarração e teto da casa grande (tavyve ou akapepum). $\mathrm{Na}$ foto ao lado, um homem branco, possivemente Anton ou Karl Lukesch, faz pose para foto na porta de entrada da casa.

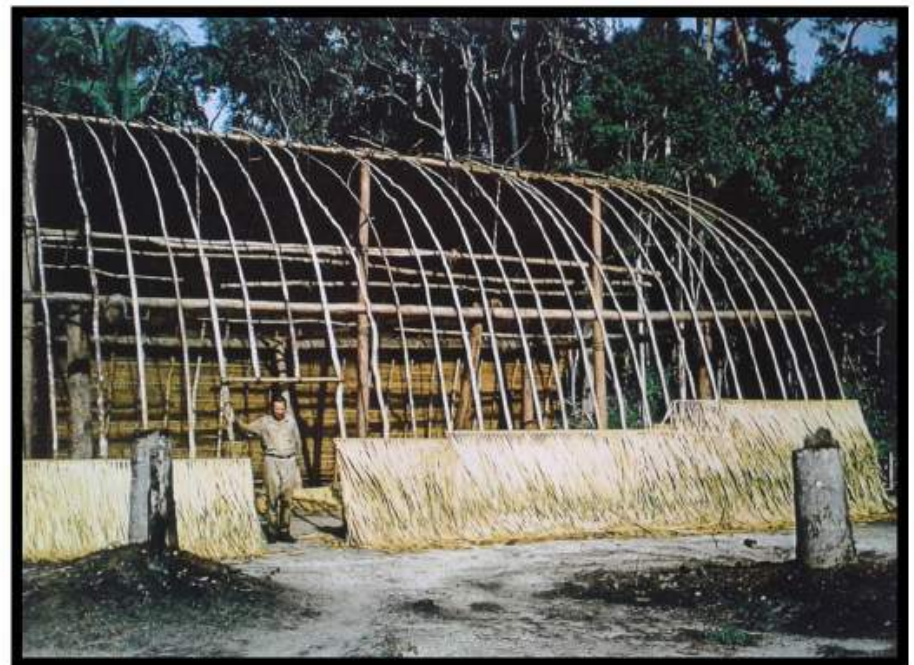


Marakauá estava voltando da roça, ao que tudo indica para a aldeia Taiuviaka, quando soube que os brancos haviam chegado. Ela confessou ter ficado muito assustada; na verdade, estavam todos assustados e eufóricos, e os Asuriní ficaram repetindo: "Onde mesmo que os brancos chegaram?". E outros que já os tinham visto diziam: "É dentro da nossa aldeia". Alguns quiseram flechar os brancos pensando que queriam fazer guerra. Quando Marakauá e seu grupo chegaram ao aldeamento em que estavam os brancos, seu pai foi o primeiro a se apresentar, ela conta:

\begin{abstract}
Meu pai falou: "Deixa primeiro eu me amostrar, depois vocês vão". Tinha uma tukaia ${ }^{96}$ de festa na frente da casa, aí meu pai foi lá perto, ele estava lá. Eles foram atrás daquela tukaia. Eles foram, foram, foram, aí branco viu ele. Um bocado de branco pegou ele, cada um veio com miçanga, roupa, chapéu e já foram colocando miçanga e roupa nele. Pegaram mais outro Asuriní, foram colocando roupa, deram facão, miçanga. Eu fiquei atrás. Eu estava bem pertinho, eu queria ir escondida. Eu queria ir andando em cada casa até chegar bem pertinho. Mas outro homem [branco] me viu e gritou: "Aqui outro índio". Meu marido gritou: "Deixa ela". Eles me pegaram e meu marido veio atrás e disse: "Não tem medo não, eles não fazem nada". Aí eles me pegaram e deram facão e miçanga e colocaram roupa. Acho que eles vestiram roupa em mim porque estavam com medo de buceta".
\end{abstract}

Takamuin também lembra do dia em que foram junto com os padres até a Taiuviaka. Como no relato de Marakauá, os muitos presentes oferecidos são um sinal de que os "brancos estavam mansos" e de que "não iriam faz nada com eles". Além disso, o índio acrescenta que, junto com os objetos, os padres teriam oferecido café amargo em grande quantidade.

Estava quase escurecendo quando foram chamar o pessoal da Taiuviaka, o pessoal falou: "Bora lá buscar eles". Eles foram. Já estava de noite. Eles foram com fogo. Podia os brancos darem lanterna pra gente, porque Taiuviaka era bem longe [comentário do narrador]. Chegaram meia-noite. Chegaram na Taiuviaka e disseram: "Chegou muito branco, agora que Araweté não vai mais matar a gente". Mas mesmo assim eles vão matar ainda [comenta o narrador]. Amanheceu o dia: "Vamos". Eles estavam

\footnotetext{
${ }^{96}$ Cabana de folhas, objeto dos rituais xamanísticos para onde o espírito em questão é atraído.
} 
indo mas os homens já tinham vindo falar com eles, outros Asuriní começaram a gritar: "Os brancos chegaram no Taiuviaka". Os brancos deram facão e miçanga, deram café também. Nem todos tomaram. Eles não colocaram açúcar, o café estava muito amargo.

Embora o relato de Marakauá também mencione o café amargo, é na fala de Takamuin que esse elemento aparece com força. 0 índio conta que os padres pediram para eles ficarem em fila, despejavam café de uma garrafa grande nas cuias de cada um e enchiam para eles beberem na mesma hora. Os índios foram tomando. Uma mulher, que fez uma expressão de nojo indicando que estaria passando mal, foi reprimida pelos outros Asuriní que disseram para ela: "Para com isso, toma calada".

Ao mesmo tempo em que "amansaram" os brancos, os Asuriní revelaram que em muitas situações eles se tornaram "reféns" da nova alteridade ao aceitarem diversas práticas impostas. A domesticação inicial dos tapy'yia (inimigos), trabalho tomado à frente pelo pajé Avona, não significou que os akaraí deixaram de ser inimigos e que deles não mais surgiriam ações nefastas. Nos relatos obtidos em 2015, verifica-se que as fotografias do contato despertaram lembranças - que eu qualificaria como positivas, contrariando minha hipótese inicial - principalmente da relação com o padre Antônio, do qual os Asuriní se recordam com certo afeto. Takamuin explica o que pra ele é uma das razões mais importantes para gostarem dos padres: "Padre Antônio é bom, deu as coisas para Asuriní, trouxe muitos presentes". A desconfiança em relação aos brancos vai voltar quando a Funai assume os trabalhos de "atração". Ouvi muitas queixas em relação ao sertanista Antônio Cotrim Soares e sua equipe, a mais forte delas quando afirmaram que ele teria oferecido café amargo em um latão, bebida que estaria envenenada para cumprir a meta de "matar os Asuriní aos poucos". As muitas mortes que se seguiram, parte delas causadas por diarréia em decorrência da ingestão do café amargo, apenas confirmam, da perspectiva dos índios, as más intenções da Funai. 


\subsection{Legendas e nomes, descrever e reconhecer}

Embora as fotografias na obra de Lukesch funcionem de forma integrada à narrativa textual, que as elucidam e apresentam, as fotos são acompanhadas de suas próprias cartelas explicativas. Desde o primeiro contato com estas imagens me chamou atenção o modo curioso que o autor escolheu para descrever e apresentar algumas das fotos nas legendas. Diante do objeto desconhecido, Lukesch fornece explicações de modo distanciado e objetivo, mas quando o referente da foto se torna extremamente exótico e não há possíveis descrições, o autor conta com a sua imaginação criativa. As legendas das fotografias são um bom termômetro para medir o teor imaginativo (e de devaneio) no projeto científico de Lukesch, além da sua devota idealização dos "silvícolas" que viviam em isolamento. 0 estranho hábito dos índios recém-"descobertos", de usar o tecido de uma rede saqueada de ribeirinhos amarrado à cabeça ou um machado como pingente, produziu legendas pitorescas para explicar "a moda primitiva", conforme mostram as imagens 5 e 6 e suas cartelas explicativas.

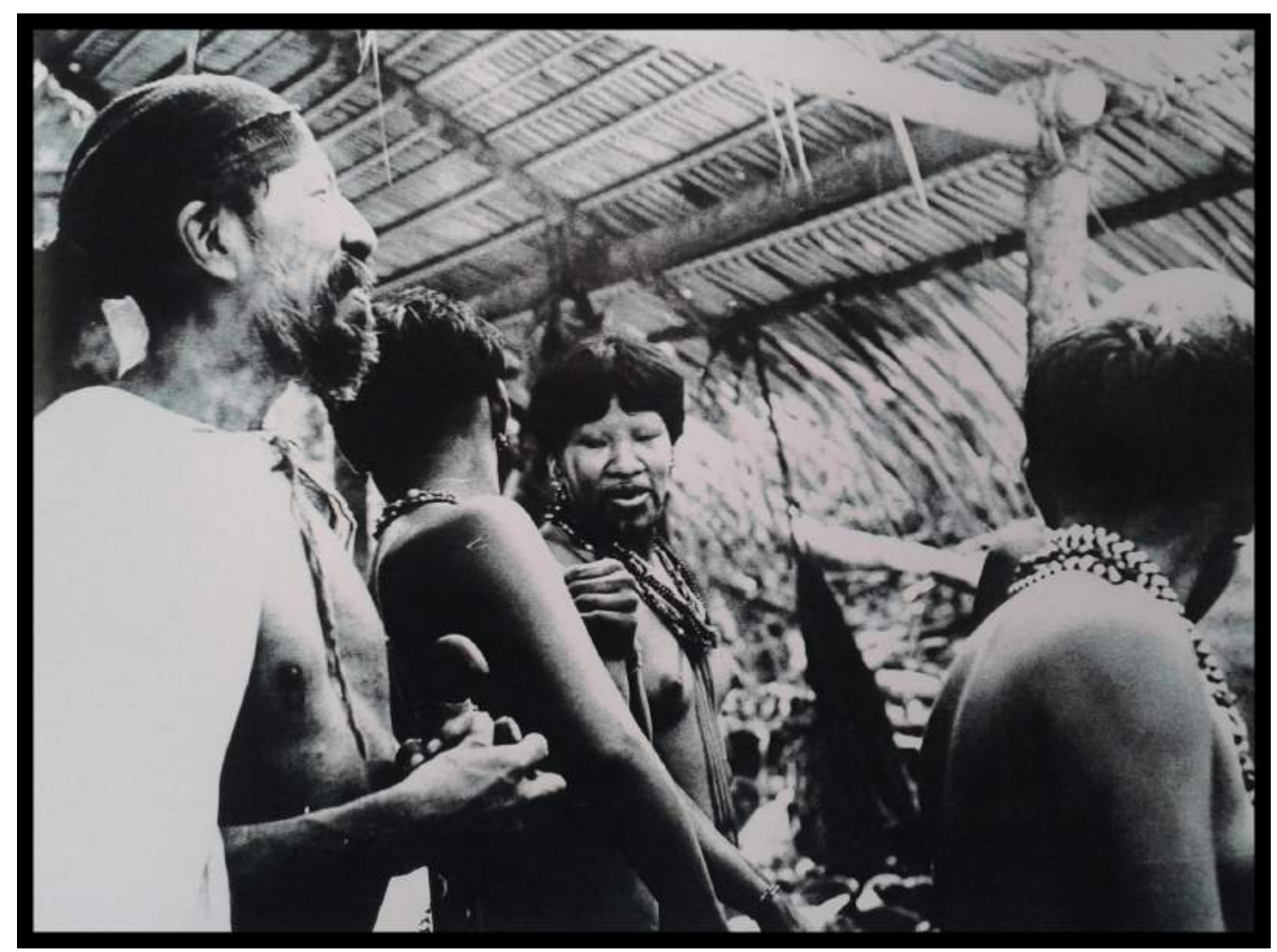

Imagem 5. "Homem vestido em traje de pirata". Foto e legenda de A. Lukesch, 1976, p. 103. 


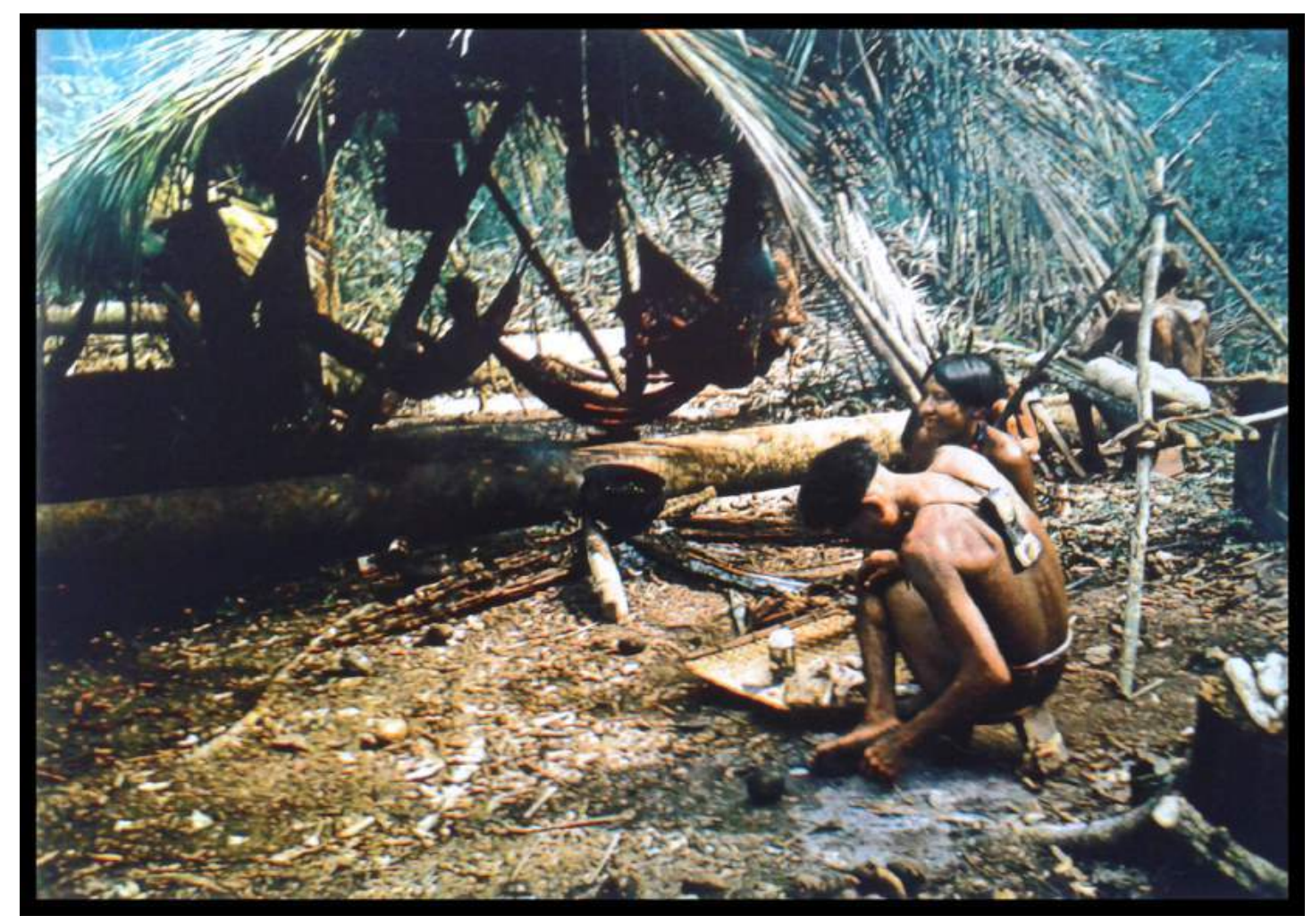

Imagem 6

"Jovem entusiasmado vestindo machado como pingente, amarrado com fibra nas costas". Foto e legenda de A. Lukesch, 1976, p. 107.

Boa parte das legendas apenas instruem o leitor a respeito da atividade que está sendo realizada, dos objetos e locais onde a ação acontece, buscando descrever o povo recém-contatado. Em outras, a imaginação e a empatia de Lukesch ganham forma em adjetivos que qualificam as ações: o homem que se deita confortavelmente em sua rede, a mulher que pinta cuidadosamente sua perna com desenhos geométricos, uma outra que prepara um delicioso mingau de mel com milho, ou ainda uma mãe que cuida do seu filho com ternura, como se vê na imagem seguinte (imagem 7). Os adjetivos reforçam a narrativa do encontro "pacífico" ao mesmo tempo em que deixam escapar um certo grau de idealização já comentada anteriormente - que, do meu ponto de vista, relaciona-se com o projeto católico do missionário - e que terminam por construir uma imagem dos Asuriní como "bons selvagens". 


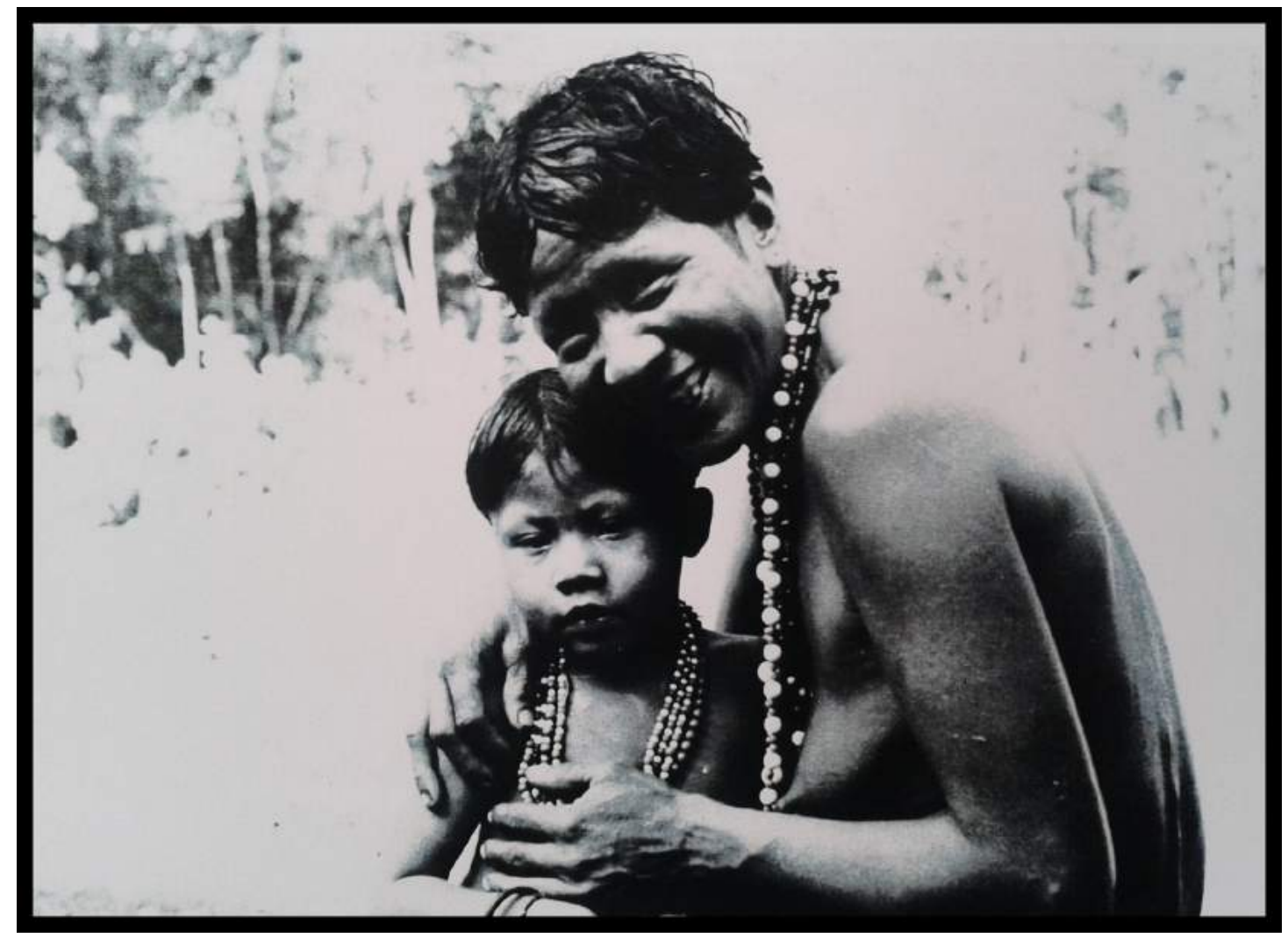

Imagem 7

"Mulher cuidando da sua criança com ternura"

Foto e legenda de A. Lukesch, 1976, p. 102.

A mulher que cuida do filho ternamente é Patuá e a criança, a menina Matuia, que hoje tem 50 anos; sua mãe faleceu há pelo menos 15. A Patuá de hoje é neta de Matuia e tem dois anos.

A circulação das fotografias "do padre Antônio", para falar à maneira asuriní, trouxe a lembrança de muitos pais, mães, irmãos, irmãs, tios, tias, primos, primas, sogros, sogras, esposas e esposos que já morreram. A atitude usual diante da foto de um "antigo" - Asuriní falecido ao qual se referem pelo termo bava -, consistia em identificá-lo indicando a relação de parentesco que ele próprio ou outra pessoa viva guarda com a pessoa retratada. De início, os nomes próprios eram mencionados no caso de o nome do morto retratado nas imagens já pertencer a uma criança ou jovem vivo; nesta situação, eles inclusive se esforçavam para me explicar a relação de parentesco entre a criança e o morto visto na foto, ao evidenciar de quem a criança herdou o nome. Veveí pediu de presente a fotografia em que Avona, o homem que amansou os brancos, é 
retratado (imagem 4) para dar para o seu neto, Itareí, de 15 anos. Avona, também chamado Itareí, é avô do lado materno do menino e é dele que o atual Itareí herdou seu nome.

Sabe-se que os Asuriní tradicionalmente trocam de nome com a morte de um parente; neste caso, substituem seus nomes por outros que pertenceram a mortos mais recuados no tempo. Não é o morto que retorna, pois tudo que é do morto tem de ser destruído e, depois de um tempo, nada resta na aldeia a não ser os ossos (ga akynguera, ossos dele) enterrados na casa grande, pois o ynga, princípio vital, segue para o caminho de Maíra, e o anhynga, espectro do morto que a morte libera, também toma seu rumo, sendo escondido pelo xamã até desaparecer. Dos mortos, o que retorna são os nomes próprios, sendo a morte a responsável pelo movimento da mudança de nomes. Souza (1994), que trabalhou com o tema da nominação entre os Asuriní em trabalho de campo no fim dos anos 1980 e início dos 1990, afirma que um velho podia chegar a ter quatorze nomes. Ela diz que todo adulto passava a usar outro nome quando alguém falecia, e que, entre crianças até dez anos, a mudança de nomes não seria corrente, permanecendo todas com o nome outorgado por ocasião do seu nascimento. Em relação à herança dos nomes, Souza observa que, embora a regra não seja restrita, há uma recorrência no fato de que pessoas do sexo feminino recebem o nome de mulheres do lado materno e pessoas do sexo masculino o receberiam de parentes homens do lado paterno (Souza, 1994, p. 91).

Informada a respeito do tabu em pronunciar o nome dos mortos, procurei, no início das sessões de exibição das fotografias de Lukesch, não questioná-los. No entanto, para minha surpresa, ao ver as fotografias, e num esforço de fazer que eu reconhecesse a pessoa retratada, muitos Asuriní enunciaram os nomes. Tal atitude me colocou, de início, diante de um impasse. Marakauá foi quem me ajudou a compreender o que se passava. Afinal, por qual razão, ao verem as fotografias do contato, eles pronunciavam os nomes próprios dos mortos? Marakauá, ao observar uma fotografia que retrata uma índia de cócoras e de costas, diz: "É Jakundá, Araweté flechou as costas dela. Não tem criança com este nome mas pode falar porque ela é muito velha". 


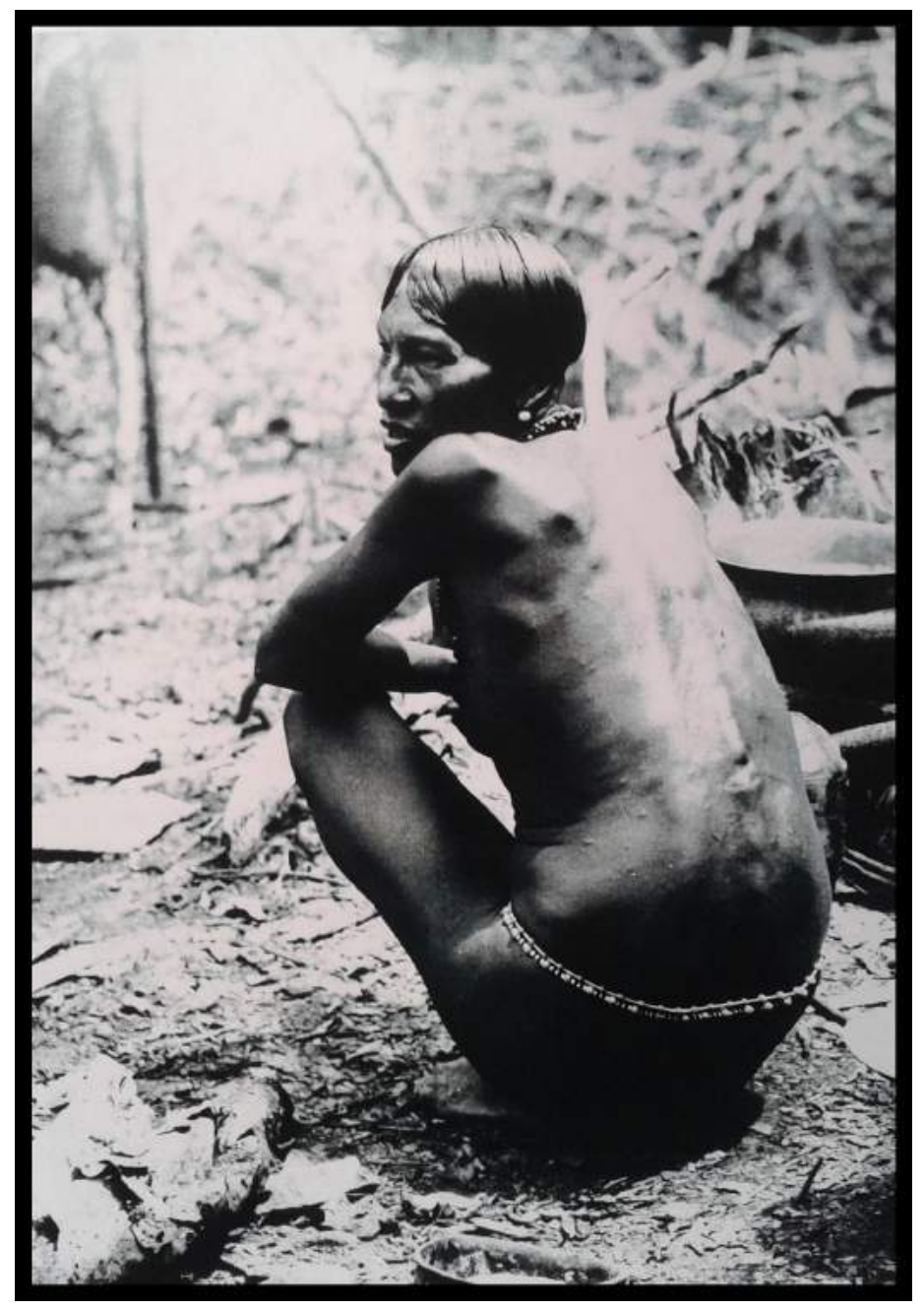

Imagem 8

"Mulher idosa rodeada por seus ítens domésticos".

Foto e legenda de A. Lukesch, 1976, p. 99.

A índia me indicava que, tendo morrido há bastante tempo, Jakundá pertenceria ao grupo dos "mortos antigos", e as memórias a ela associadas poderiam ser lembradas, bem como seu nome, sem prejuízos. Este foi o caso da grande maioria dos "antigos" retratados pelos padres. 0 tabu em relação ao nome do morto recente continua vivo, e o perigo existe, pois a desintegração da pessoa libera o espectro anhynga. Neste caso, pronunciar o nome do morto, assim como ver a sua fotografia ou simplesmente se lembrar dele, representa um risco iminente pois o pensamento, o nome e a imagem podem atrair seu anhynga para perto da aldeia. Em maio de 2015, confirmou-se o fato de que não é 
desejável que se veja imagens de recém-falecidos. A enfermeira ${ }^{97}$ da aldeia Ita'aka me contou que os índios pedem constantemente que ela apague as fotos do bebê (filho de Taymira), falecido há cerca de oito meses, do seu celular. Sem que ninguém tenha formulado claramente, acredito que para eles haja relação entre a conservação das fotos e o fato de a enfermeira ter sonhado com o bebê morto por noites e noites seguidas após seu sepultamento. A índia Ipikiri disse à enfermeira que ela estaria tendo pesadelos com a criança porque o "espírito do bebê" estaria rondando sua pessoa.

Voltando aos "mortos antigos", observei que as fotografias de Lukesch acionaram memórias do passado e, mesmo que algumas lembranças do contato estivessem carregadas negativamente, a recordação dos parentes e de seus nomes teve uma marca positiva. A relação entre nomes e memória já havia sido notada por Souza (1994), que, em sua etnografia, observa a dimensão histórica dos nomes entre os Asuriní. A pesquisadora afirma que, ao mencionarem seus nomes, sempre o faziam contando fatos relacionados aos parentes dos quais os herdaram, emergindo, assim, relatos envolvendo acontecimentos do tempo em que este ou aquele indivíduo faleceu, histórias pessoais do informante ligadas ao morto, dentre outras recordações que indicariam "[...] a existência de uma dimensão cognitiva dos nomes pessoais, no sentido em que os nomes seriam um dos recursos da percepção histórica e da rememoração do passado" (Souza, 1994, p. 75). Podemos dizer que as fotografias de Anton Lukesch, ao circularem nas aldeias, também entraram no jogo em que se movem nomes e memória.

A seguir, apresento ao leitor as descrições e explicações que acompanham as fotografias na obra Bearded indians of the tropical forest, e quais são as indicações dos Asuriní ao verem as imagens. Trata-se de pranchas que trazem dezoito fotos nas quais pessoas são retratadas, que contêm as legendas do padreetnólogo traduzidas para o português e os nomes dos parentes identificados pelos Asuriní, que não deixam de funcionar como uma etiqueta para as imagens. Embora praticamente todos os Asuriní tenham visto as fotos, quem se empenhou

\footnotetext{
${ }^{97}$ As aldeias Asuriní contam com um posto de saúde aparelhado e com um técnico de enfermagem do DSEI- Distritos Sanitários Especiais Indígenas, que permanecem em tempo integral nas aldeias. Ângela, enfermeira do Ita'aka, acompanhou os últimos dias do bebê que veio a falecer e, a esse respeito, foi quem me forneceu informações, já que evitei conversar sobre o assunto com os Asuriní.
} 
em identificar as pessoas retratadas foram os mais velhos que, de fato, lembravam-se dos parentes. Este trabalho, tão bem realizado por Burí, Boaiva, More'yra, Marakauá, Koati, Takamuin, dentre outros Asuriní com mais de 60 anos, foi uma reação espontânea diante das imagens. Transcrevo os nomes dos "antigos" retratados e não a indicação do termo de parentesco em relação a quem vê, pois privilegio, aqui, a relação dos Asuriní com a legião de "antigos" que são também seus mortos. Tal procedimento de refazer as relações pessoais e de parentesco com os parentes retratados será realizado no capítulo 4.

Proponho que o leitor observe o movimento que vai da descrição do exótico ao reconhecimento do próximo, sendo que não são apenas os Asuriní que realizam o reconhecimento; o padre-etnólogo também se aproximou dos índios nas poucas semanas de convivência "harmoniosa", "amigável" e "cordial", como ele mesmo descreveu. Tal empatia resultou na qualidade imaginativa e, eu diria, idealizada de algumas de suas legendas, como forma de descrever a experiência que viveu entre os índios do Ipiaçava. Do contrário, os Asuriní também se viram diante da relação com o "outro". Tanto porque os mortos são uma alteridade que deve ser afastada dos vivos ${ }^{98}$, ainda que suas memórias sejam previstas e bemvindas, quanto porque, para os jovens, ver os índios barbados que viviam praticamente em isolamento os colocou diante de uma alteridade quase que radical e até "exótica", o que os levou a notar o quanto são diferentes dos "antigos". Por não poder ter acesso mais aprofundado ao ponto de vista dos jovens em relação às imagens, ficaremos com a identificação e com os nomes, efeitos produzidos pela circulação das fotografias entre os mais velhos.

\footnotetext{
98 Não pretendo explorar dilemas simbólicos relacionados aos mortos enquanto "outros" entre os Asuriní, embora considere que este tema foi pouco explorado. Müller abordou a presença dos mortos no contexto dos rituais de flautas, os Turé, ao fazer uma análise a partir dos pares vivo/morto e guerreiro/morto (vítima); ver Müller, 1993, Cap. 2 - "Turé, ritual das flautas". Souza (1994), ao falar da nominação, explorou a relação entre nomes e memórias dos "outros", tratando dos mortos e dos brancos como as alteridades Asuriní. Neste trabalho, nos interessa a dinâmica "sociológica" da circulação das imagens e o que elas provocaram; fotos evocaram memórias dos "antigos" (bava, Asuriní que já morreram) e de seus nomes.
} 


\section{prancha 2}

\section{Legendas e nomes}

(Fotos: Anton Lukesch, 1971)

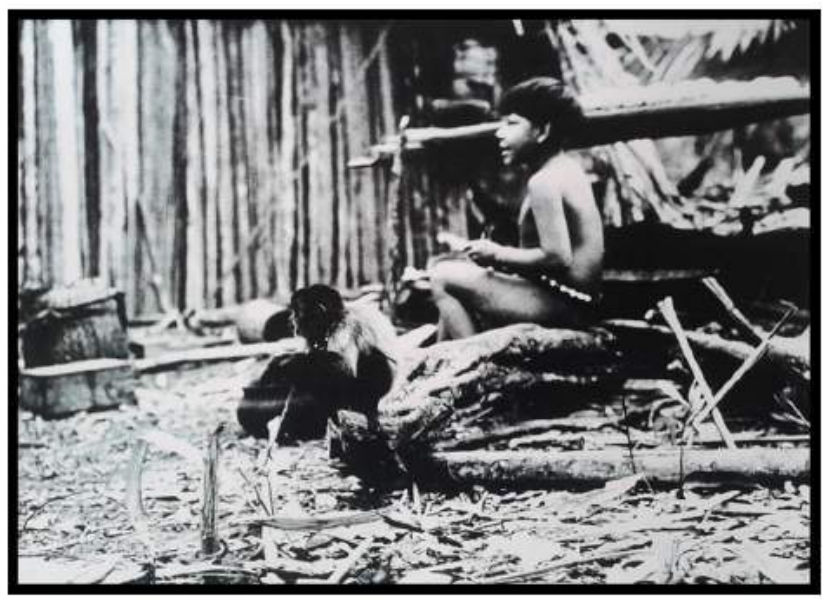

A. LUKESCH:

"Menina em sua hora de brincar".

ASURINi:

"Murukaí quando era pequena".

"Casal asurini voltando da roca para

A. LUKESCH: casa".

ASURINi:

"Kari e sua esposa, Ajui".
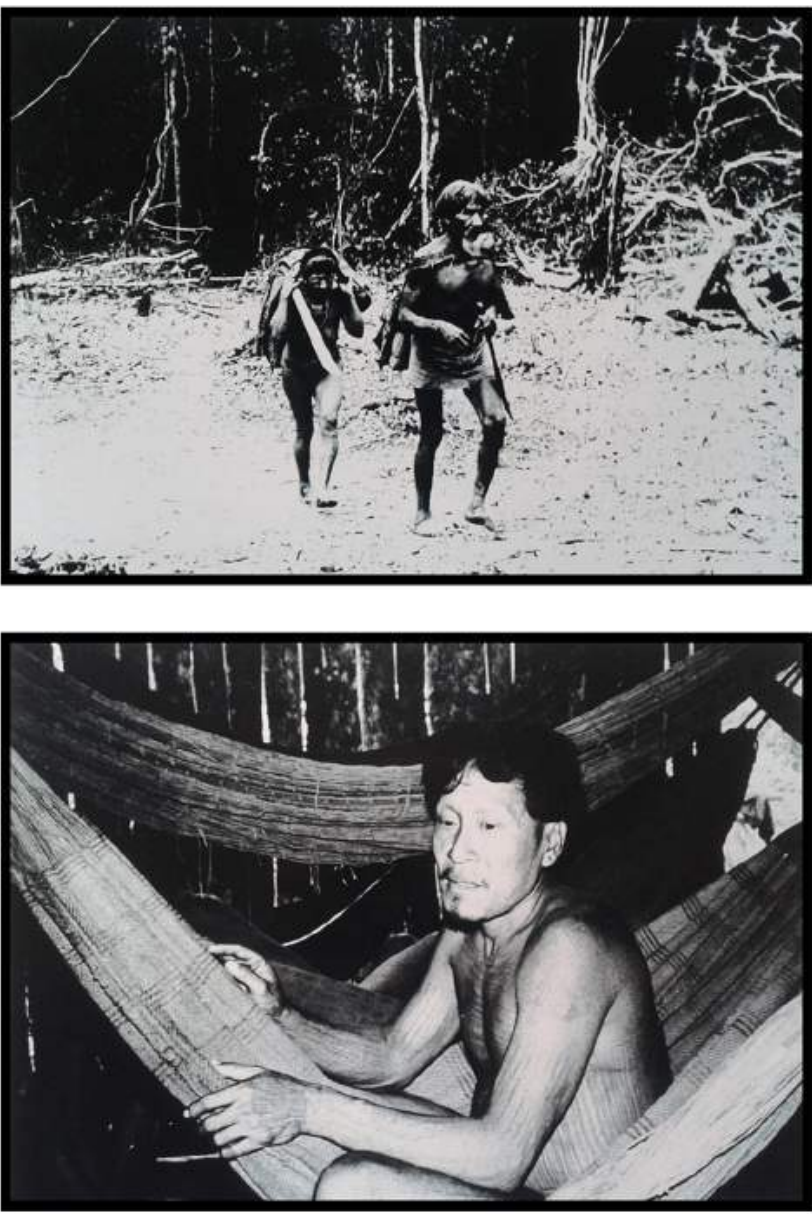

A. LUKESCH:

"Nosso guia asurini, tipo intelectual"".

ASURINi:

"Maiv".

"Mulher tecendo algodão no tear".

A. LUKESCH:

ASURINi:

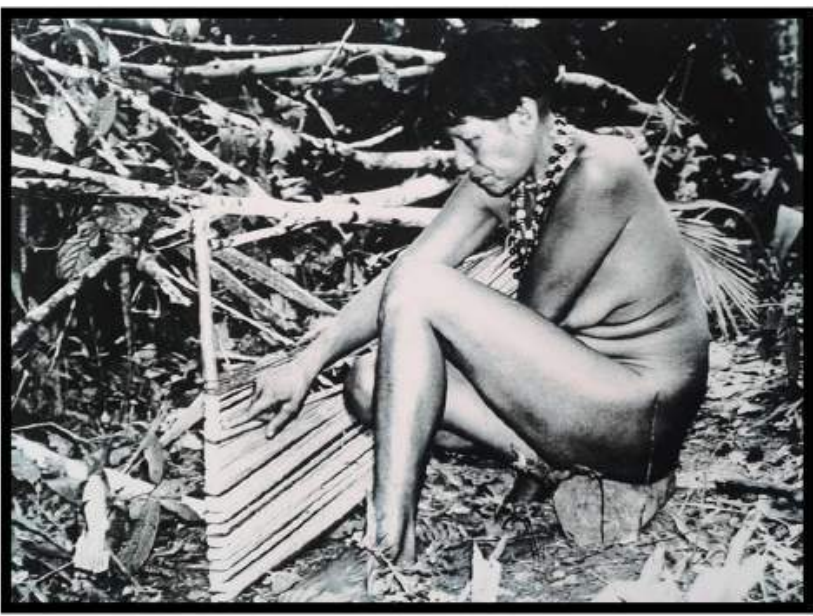




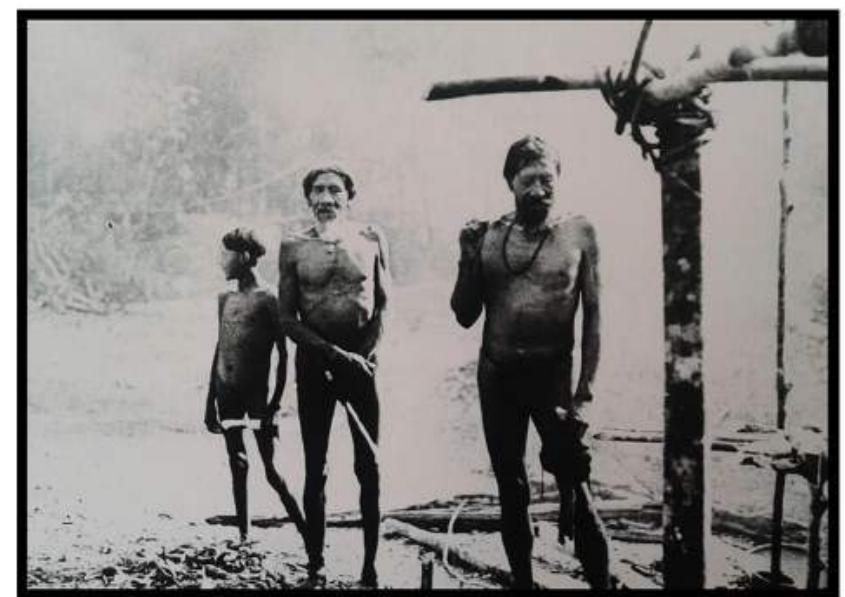

A. LUKESCH:

"Três geraçōes de Asurini".

ASURINi:

"Takiri, seu pai Kari e seu tio

Panega'e". (Da esquerda para a direital.

"Mulher e seu macaco de estimasão".

ASURINi: "Juemaí".
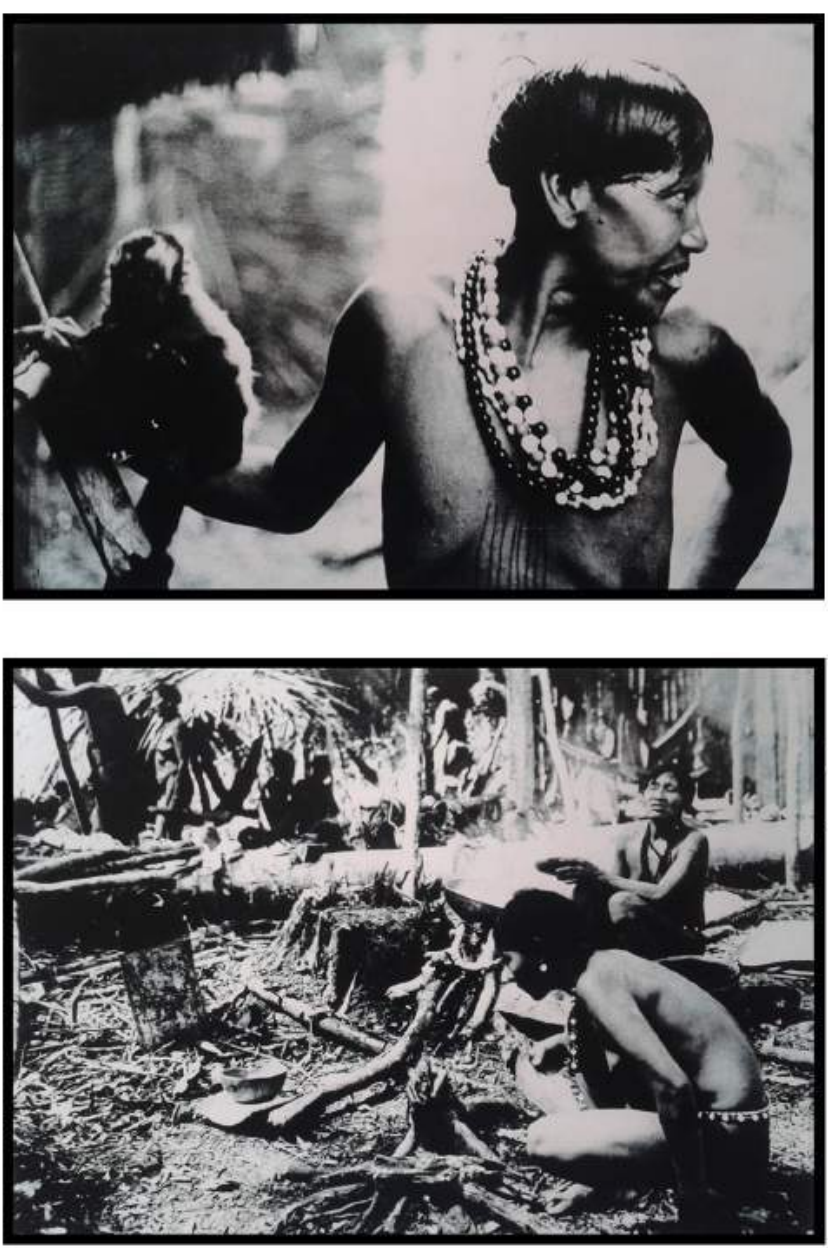

A. LUKESCH:

"Mulheres cozinhando do lado de fora".

A. LUKESCH:

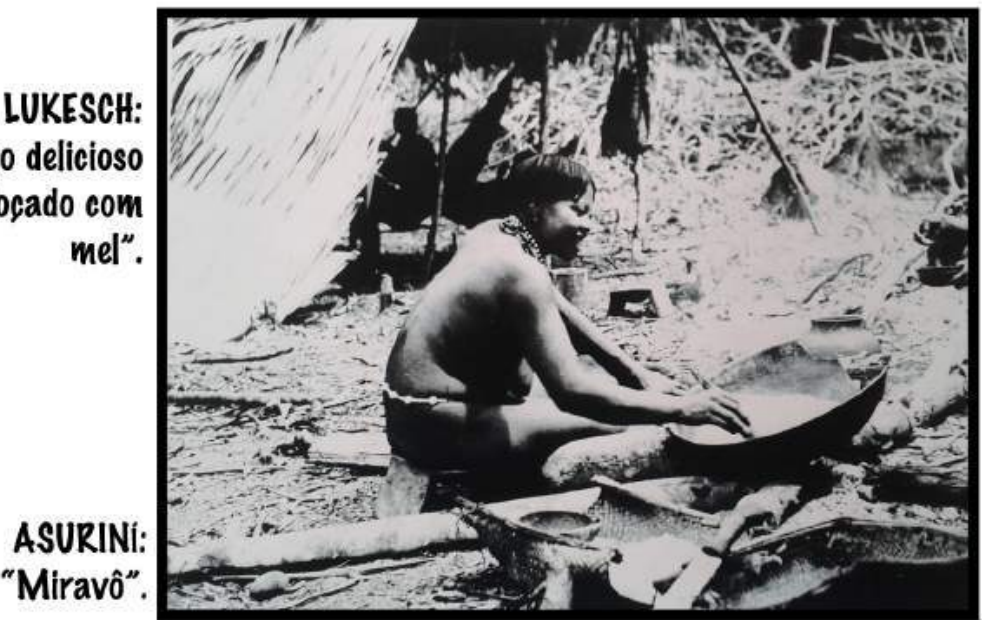

ASURINi:

"Mulher na frente é Pivari ou Arapoá (não houve consenso) $e$ atrás é Mapurugi".

"Mulher preparando delicioso mingau de milho adosado com 


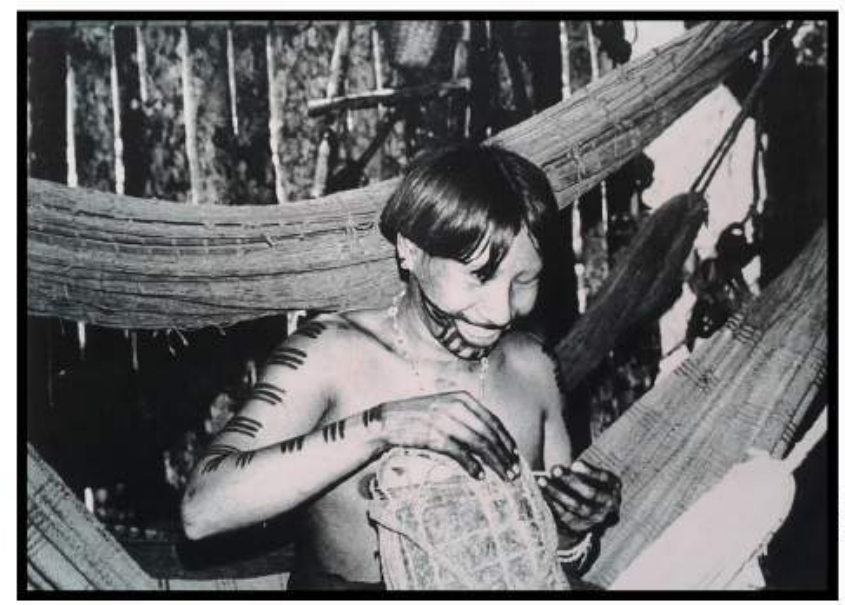
A. LUKESCH:
"india como costureira".

"Homem com arcos, flechas e todos os seus pertences se deslocando para a aldeia grande (ao fundo: maloca)".

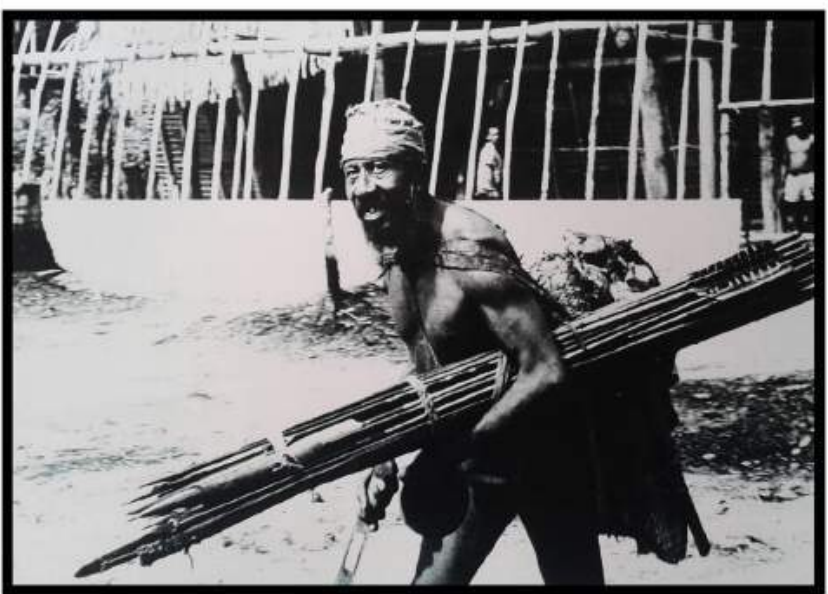

ASURINi:

"Moteri".

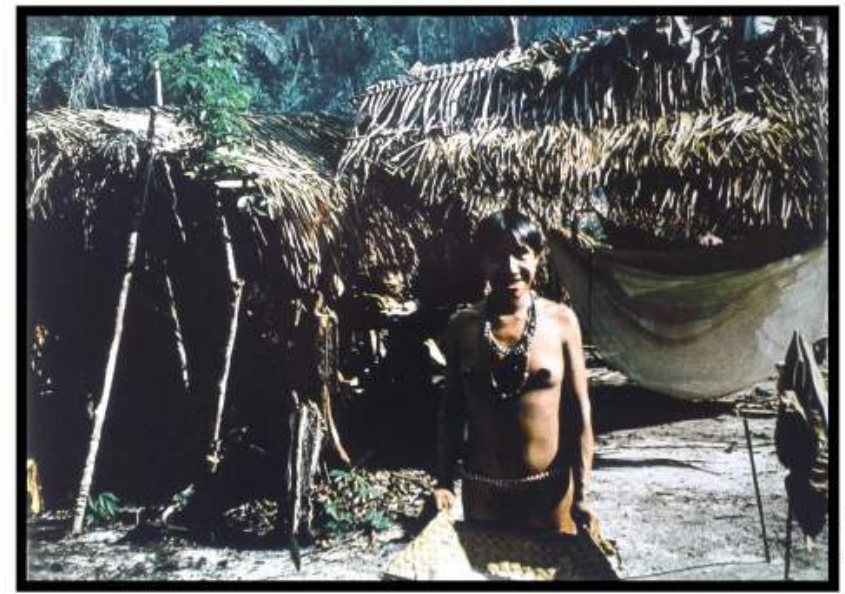

\section{A. LUKESCH: \\ "Mulher com peneira de} mandioca".

A. LUKESCH:

"Trabalho doméstico ao ar livre lestrutura triangular com bolas de mandioca para secagem)".

ASURINi:

"Kari à direita, Ajuí ao meio e

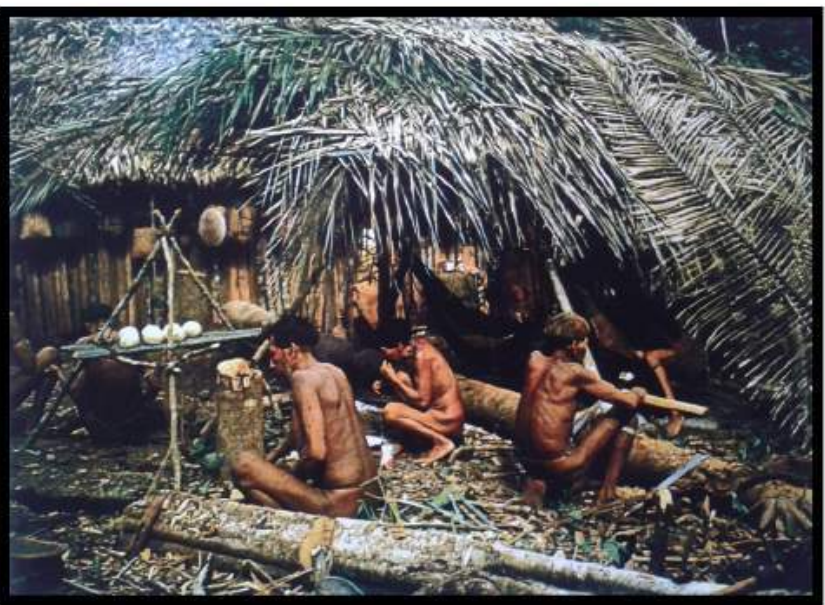

ASURINi:

"Marakavá".

Panega'e à esquerda". 


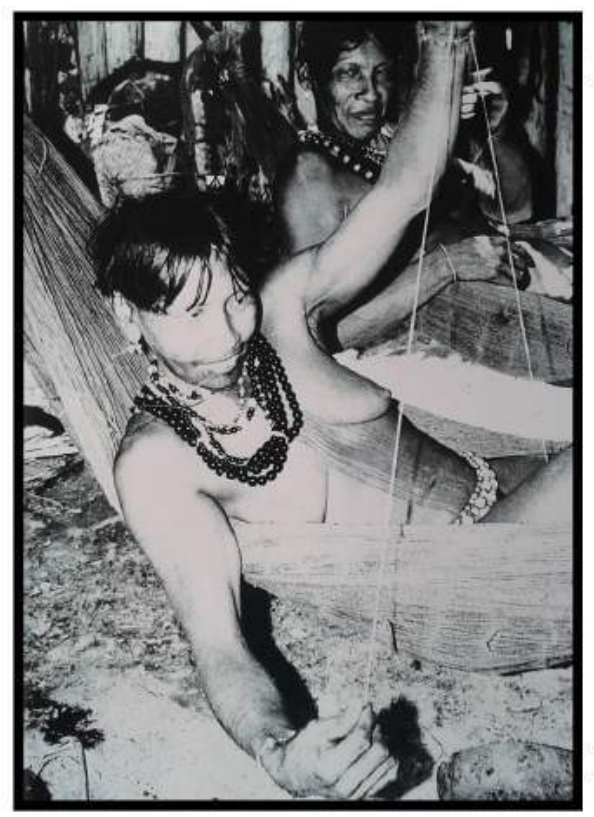

A. LUKESCH:

"Mulher fiando algodão".

ASURINI:

"Mapurugi e Jakundá ao fundo".

A. LUKESCH:

"Mulher no caminho para a aldeia vizinha (mulher carregando criansa e criancea carregando macaco de estimacãol".

ASURINi:

"Matuia crianea com macaco e sua mãe, Patuá".
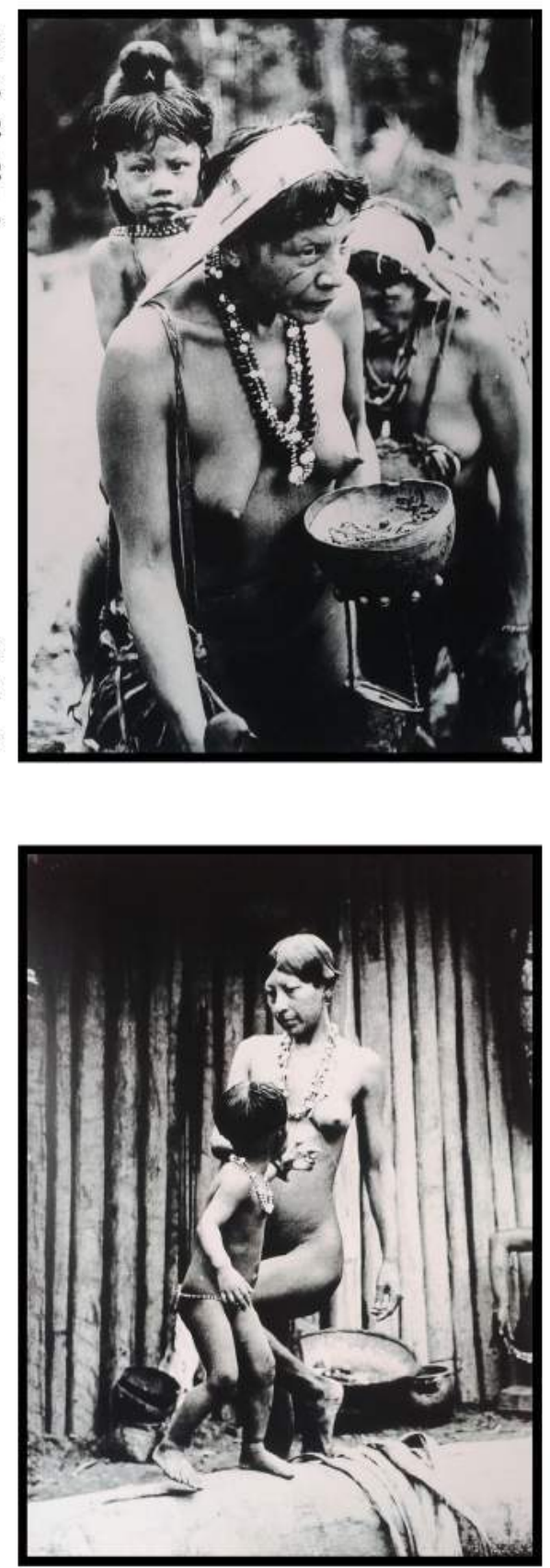

A. LUKESCH:

"Uma menina, sempre perto da sua mãe".

ASURINi:

"Maia com filha dela, Kuipiuna". 


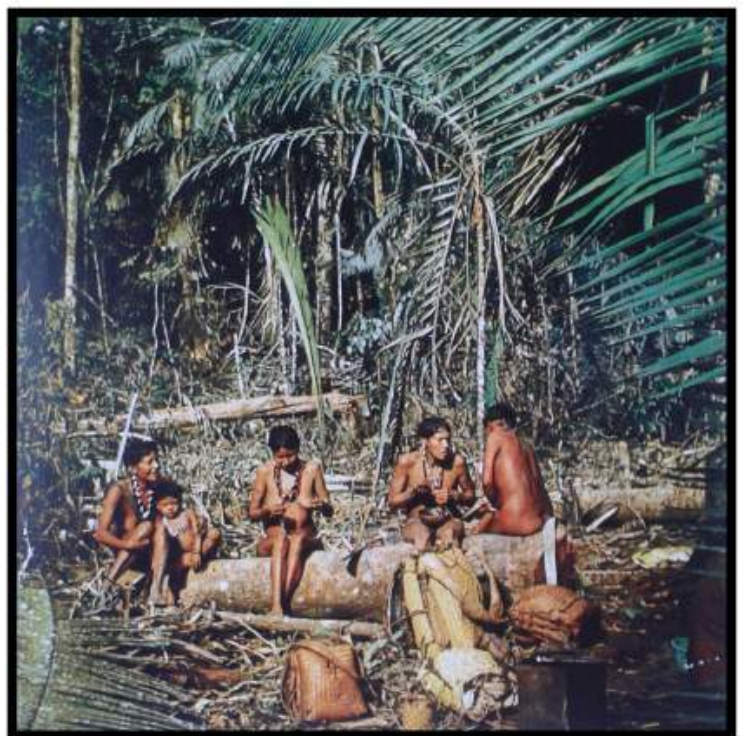

A. LUKESCH:

"Conversa entre mulher".

ASURINi:

"Esquerda pra direita: Matuia crianca com sua mãe Patuá, Arapa'i, Pivari (Jakundá) e l'á".

A. LUKESCH:

"Hora de lazer de um homem velho".
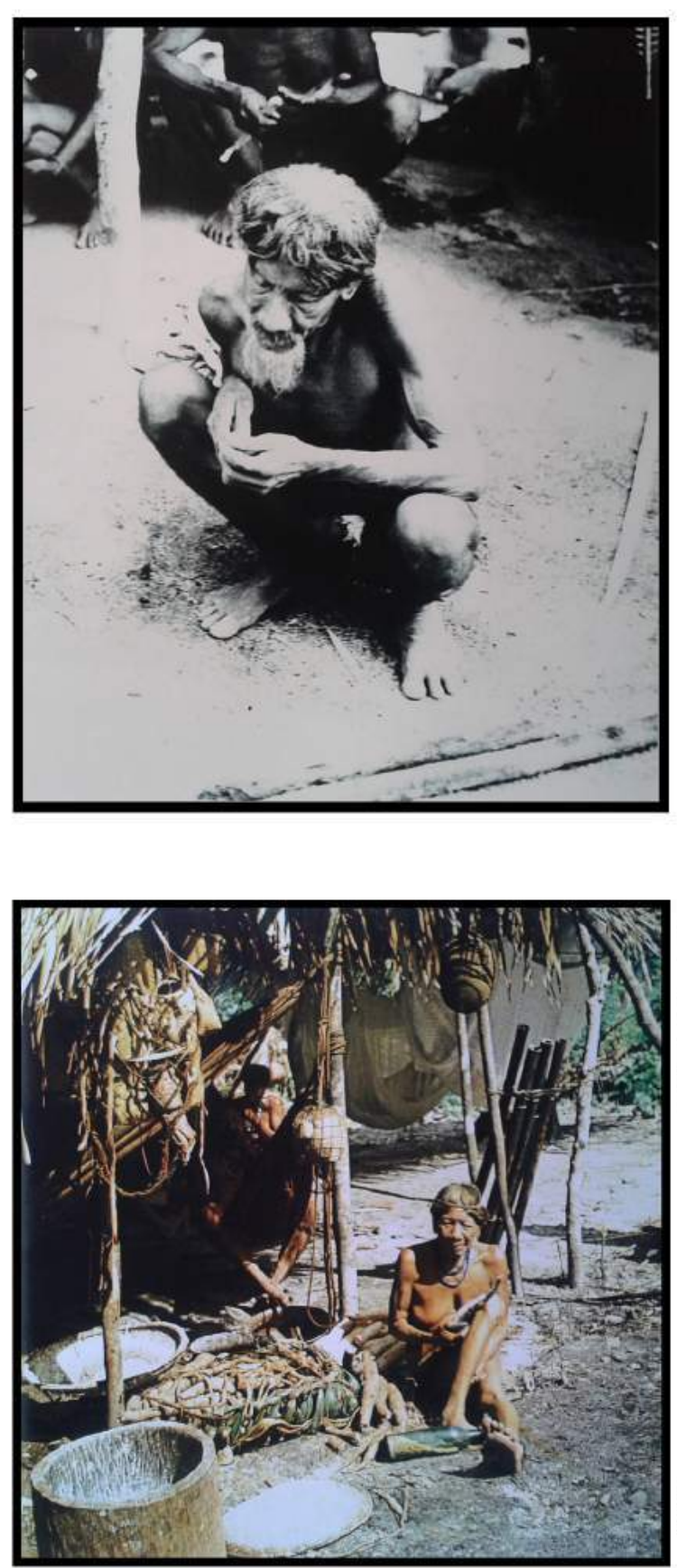

A. LUKESCH:

"Mulher com sua colheita de raizes de mandioca, suas peneiras e seu pilão para uso doméstico".

ASURINi:

"Pirapevi" . 


\subsection{Barbas, poses e presentes}

A presença da barba entre um povo "genuinamente isolado" chamou tanto a sua atenção que Anton Lukesch incorporou o traço ao título do livro, adjetivando os índios da floresta tropical. No entanto, embora dê destaque para esse elemento, pouco se dedica a descrever ou explicá-lo; exatas três linhas são apresentadas pelo autor: "Muitos dos homens têm uma longa barba que alcança a parte superior do peito cobrindo o pescoço. A cor da barba é frequentemente avermelhada, do urucum (Bixa orellana) que eles gostam de usar como tintura" (Lukesch, 1976, p. 24 e 33).

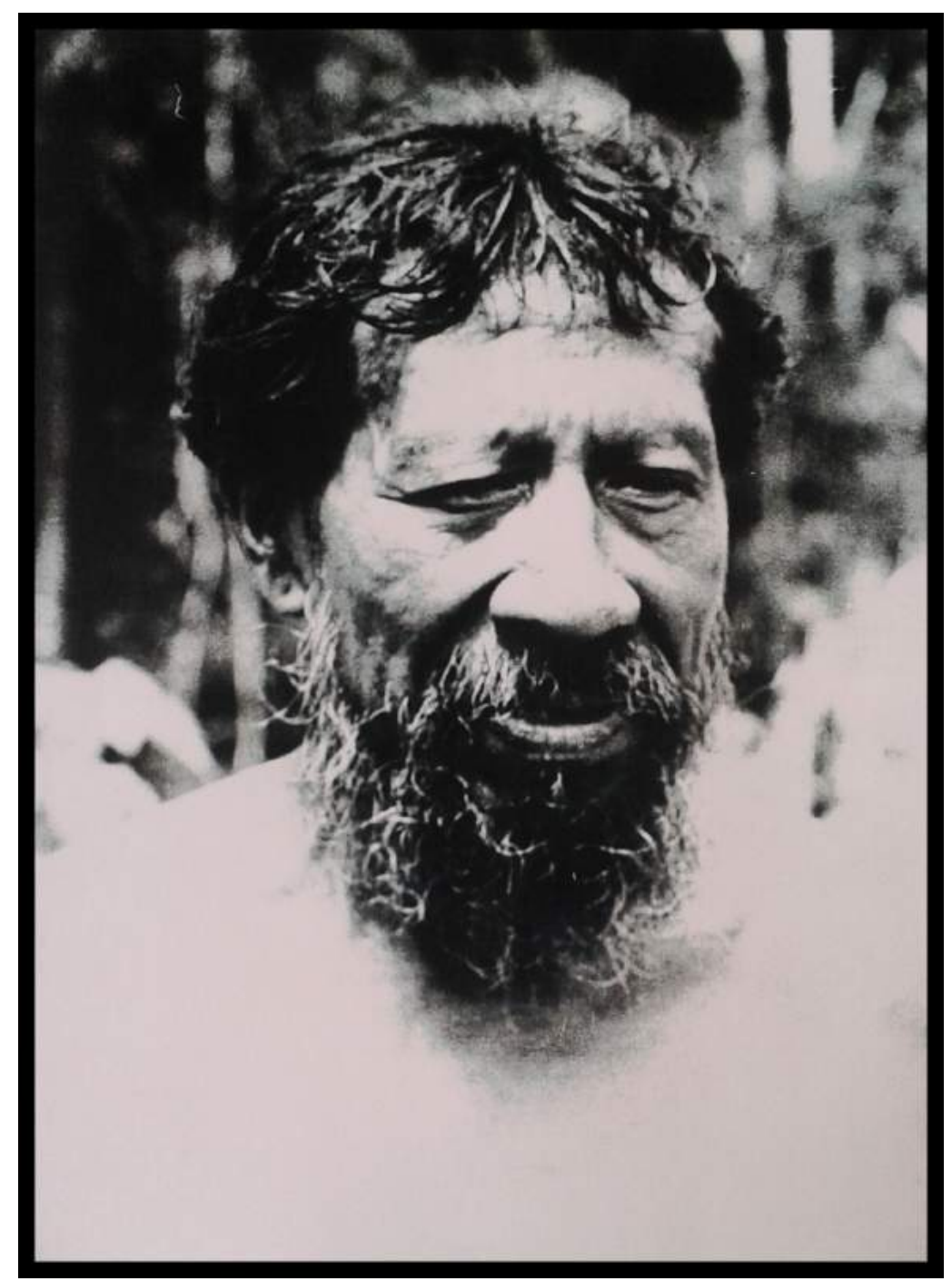

Imagem 9

"Típico Asuriní barbado". Legenda de A. Lukesch, 1976, p. 27. Identificação asuriní: "Panega'e". 
No entanto, ao contrário do que observa Lukesch, a presença da barba não era um "traço típico" asuriní, mas refletia uma situação contingencial. Numa tarde em que mostrei as fotografias dos padres ao grupo doméstico de Koati, Boaiva, um velho de 65 anos, explicou-me que eles sempre usaram uma planta chamada marupá, que, por suas propriedades cortantes, funciona como uma navalha para tirar a barba (alguns me disseram se parecer com uma taquara, outros com um capim). Entretanto, como nos anos anteriores ao contato as guerras com inimigos eram praticamente ininterruptas, obrigando os Asuriní a abandonar aldeamentos e acampamentos, eles teriam perdido o marupá. A presença da barba nas fotografias também se mostrou um elemento exótico para os índios mais jovens. Koatirei, de 20 anos, disse após ver as imagens: "Eu não sabia que a gente era assim. Não sabia que a gente era tão barbudo".

A experiência anterior entre os Kayapó ${ }^{99}$ proveu Anton Lukesch do conhecimento de que os nativos sustentam uma profunda desconfiança em relação às atividades realizadas por visitantes, antropólogos ou pesquisadores de campo, especialmente vinculadas à tomada de fotografias. Entre os Kayapó, os padres teriam enfrentado dificuldades com a fotografia desde o início, pois estes índios identificavam a tomada de fotografias com o "roubo da alma". Lukesch afirma que o termo empregado pelos Kayapó para se referirem à "alma" é o mesmo que atribuem à fotografia, ao retrato e à sombra, todas estas, "coisas misteriosas". A desconfiança das mulheres Kayapó em relação à fotografia teria permanecido mesmo depois do longo contato com a "civilização"; Anton Lukesch revela nunca ter usado flash para não assustá-los e para "não atiçar sua velha desconfiança" (Lukesch, 1976, p. 22). Entre os Asuriní, algo muito diferente foi observado.

\footnotetext{
Uma completa contradição a esta atitude nós encontramos no comportamento dos índios do Ipiaçava. Com interesse benevolente eles seguiram todas as nossas atividades. Quando nós estávamos tirando fotos, eles ficavam até mesmo parados e posando sorridentes para nós [refere-se à figura 28 do livro, reproduzida neste capítulo como imagem
}

\footnotetext{
${ }^{99}$ Lukesch publicou alguns trabalhos a partir de sua permanência de campo entre os Kayapó, ocorrida anos antes de realizar a expedição que contatou os Asuriní. Ver Lukesch, 1956 e 1968.
} 
10]. Eles obviamente acreditaram que nós estávamos tentando vê-los melhor através da coisa misteriosa [mysterious thing] com seu grande olho, apontada para eles (nossa câmera), fascinados pela sua aparência. Sempre que o meu irmão (Pai Karl) estava usando o flash era muito divertido, eles aplaudiam com risos altos e generalizados (Lukesch, 1976, p. 22).

A fotografia indicada na metade do trecho acima transcrito é a de uma jovem mulher à frente de uma casa. Ela leva as duas mãos à altura da cabeça como se estivesse no meio de um gesto, interrompido pela foto. A perna esquerda está à frente numa postura de pose; enquanto realiza uma pequena torção do tronco para olhar para a câmera, esboça um sorriso.

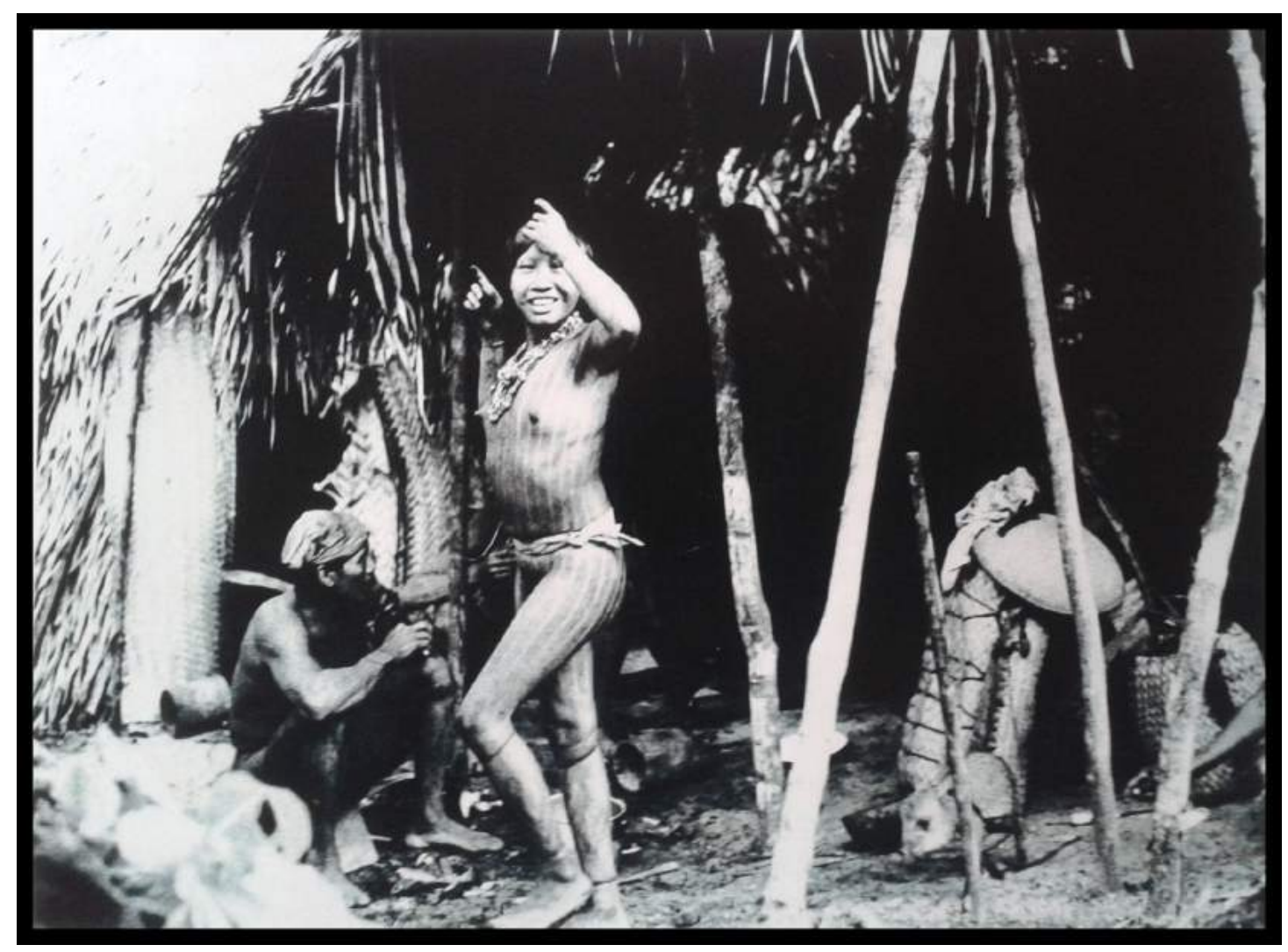

Imagem 10

"Mulher posando para foto". Foto e legenda de A. Lukesch, 1976, p. 70. Identificação asuriní: "Moteri".

É incontestável que os Asuriní estavam à vontade diante dos novos interlocutores; caso contrário, por que tantos sorrisos gravados pela câmera? (ver prancha 3). Os índios compreenderam bem que, de fato, os padres estavam 
fascinados com a sua aparência. A respeito do flash, estranha-me a informação de que eles teriam aplaudido; que o relampejo de luz artificial tenha provocado risos creio ser possível, mas a imagem de índios recém-contatados aplaudindo o flash me parece um exagero. Em verdade, a atitude receptiva dos índios diante da presença da câmera e os sorrisos presentes nas imagens reforçam a narrativa que Lukesch constrói de que o contato foi pacífico e que, aceitos como amigos, os brancos puderam compartilhar o ambiente de "harmonia" da comunidade, harmonia atribuída, não apenas às regras e normas das "tradições tribais", mas também ao isolamento dos "silvícolas" do Ipiaçava (Lukesch, 1976, p. 21). A fotografia seguinte capturou uma pequena cena da convivência e troca amistosa entre o padre Anton Lukesch e uma índia Asuriní. Embora o autor do livro nada comente, Karl Lukesch deve ter feito o papel de fotógrafo.

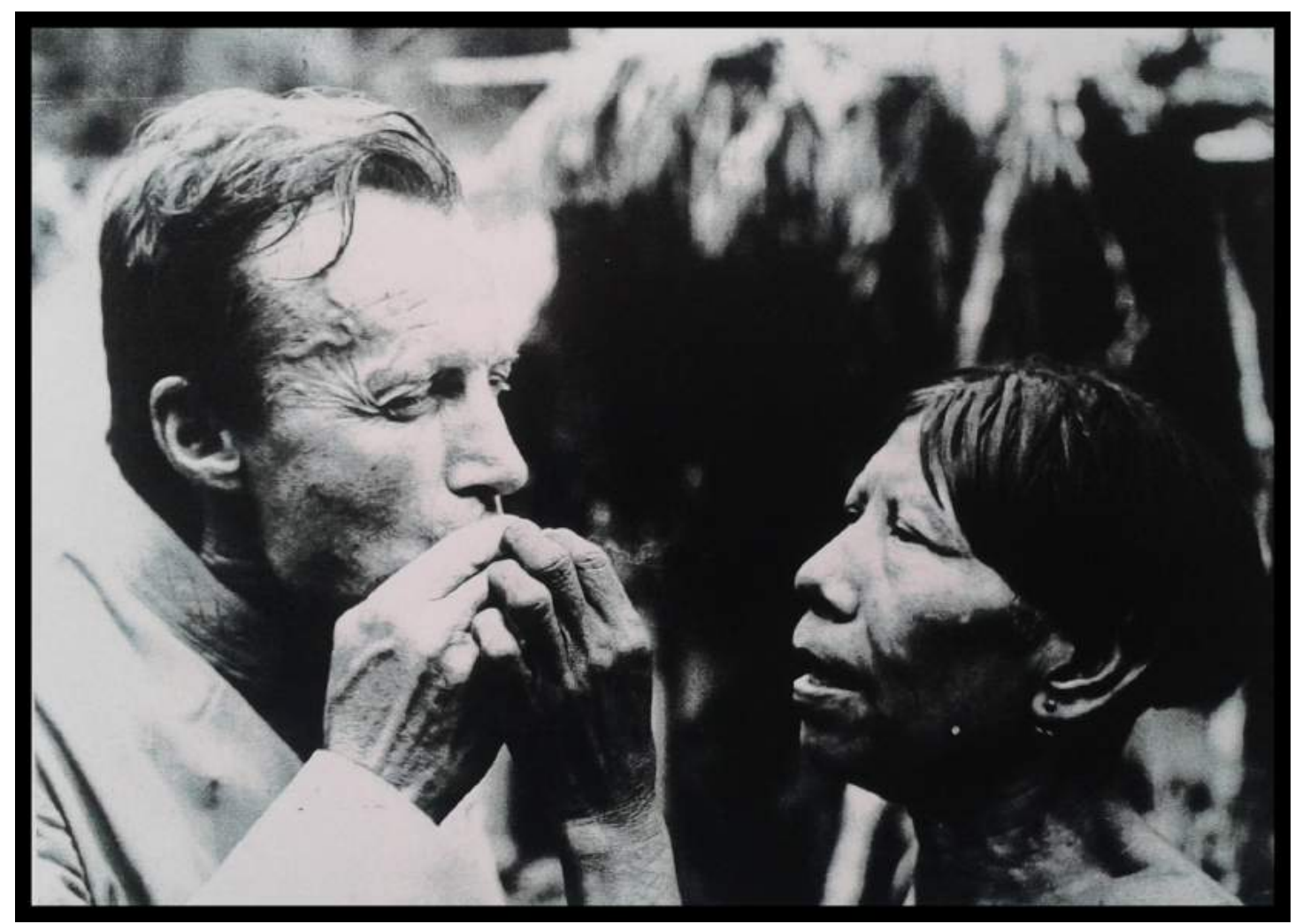

Imagem 11. "Autor aprendendo a fumar da maneira asuriní".

Foto: Karl Lukesch (embora a imagem não esteja creditada a ele) e legenda de Anton Lukesch, 1976, p. 76.

Identificação asuriní: "Uvy". A mulher retratada é mãe da Marakauá, que pediu esta imagem de presente. 


\section{prancha 3}

\section{Poses e sorrisos diante da câmera dos padres}

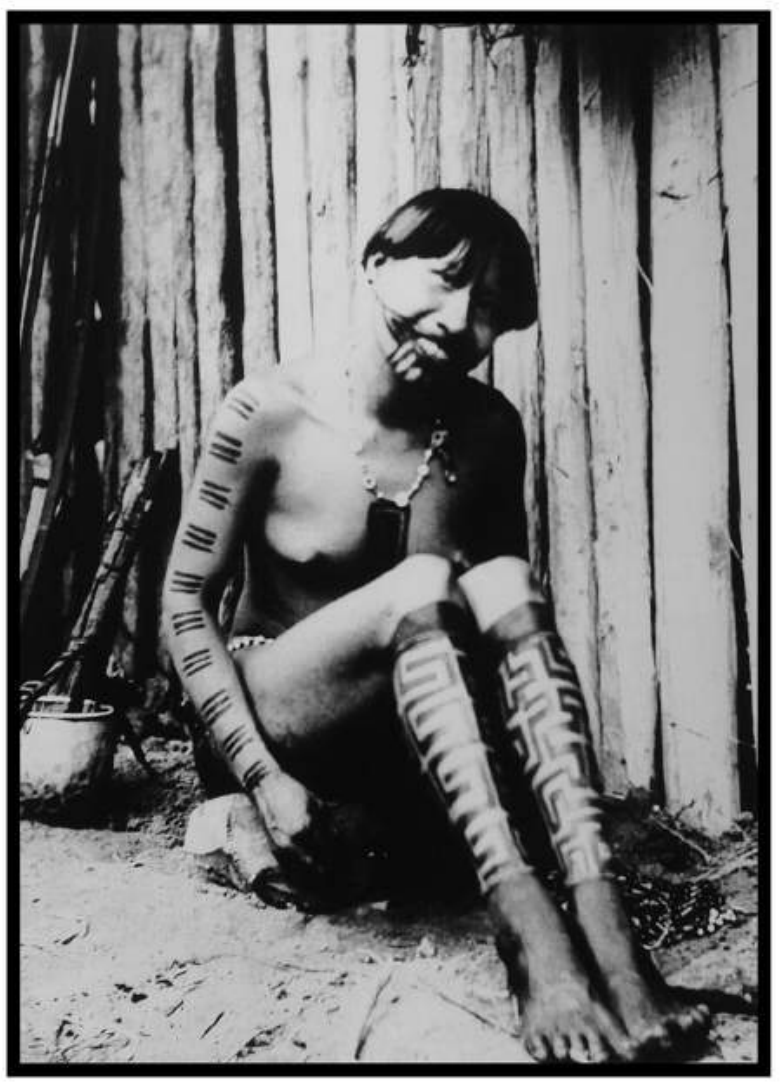

A. LUKESCH: "Mulher pintada". ASURINi: "Marakavá".

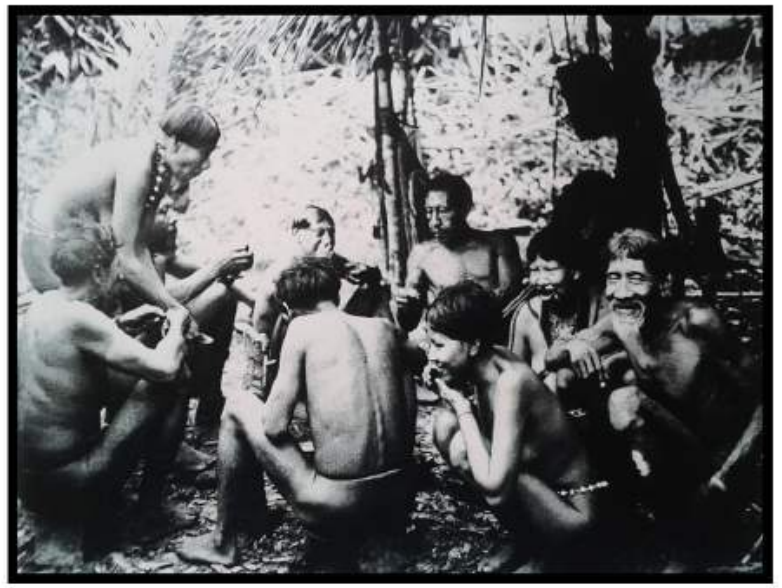

A. LUKESCH: "Refeigão asurini".

ASURINi: "Kari là direita de barbal, Burí latrás de Kari), Kureri (atrás de Burí na rede), Ajurui lagachada em primeiro plano), Arapaí (mulher curvada à esquerda), Avakaré (atrás da Arapail. Os dois homens sentados e de costas não foram identificados.

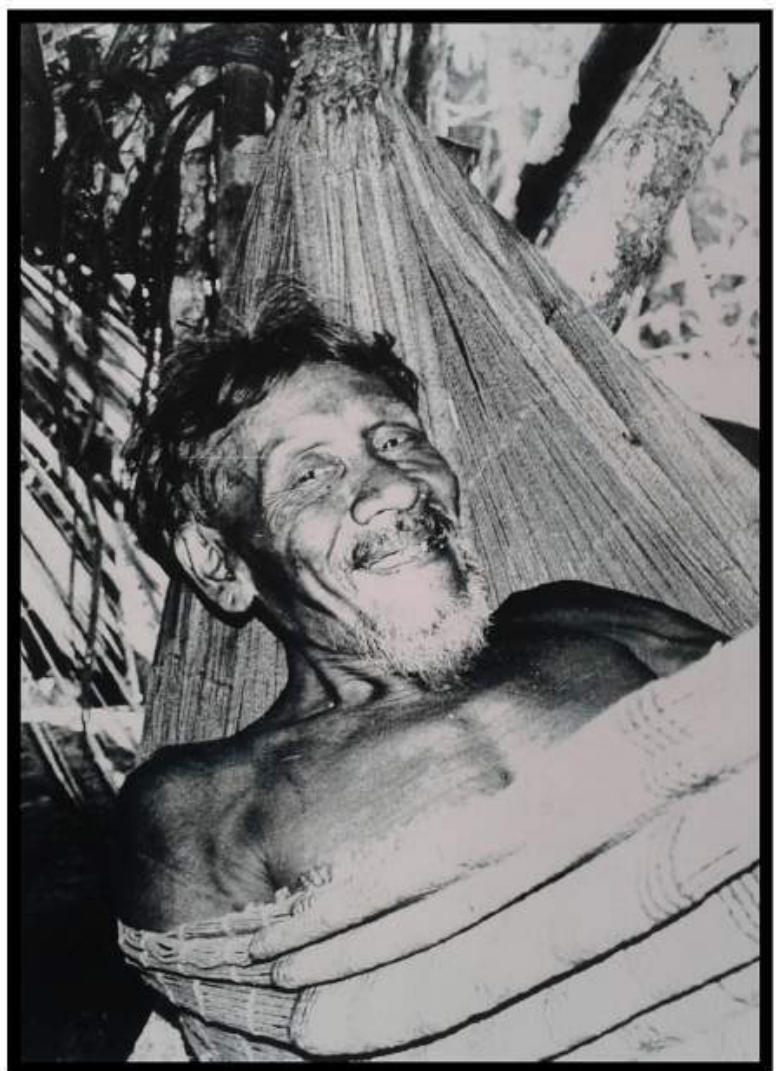

A. LUKESCH: "Confortável repouso ao meio dia na rede asurini". ASURINi: "Kupen".

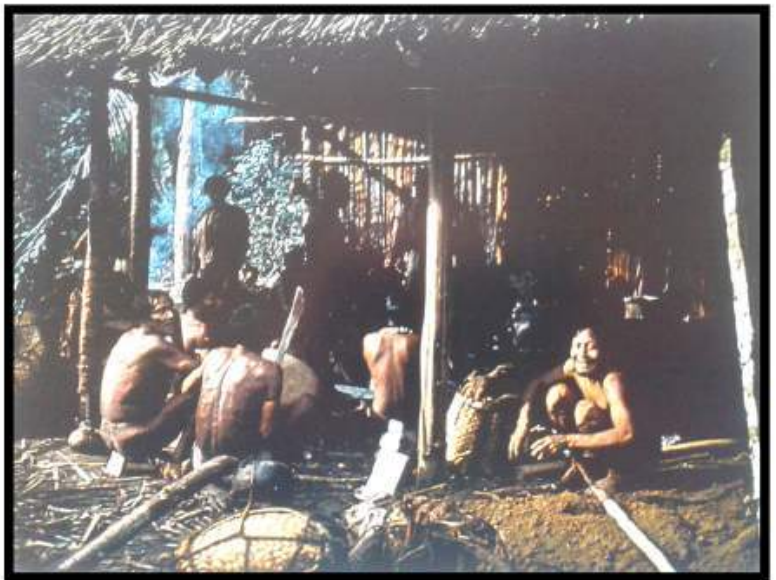

A. LUKESCH: "Homens sentados juntos após chegarem em nosso acampamento".

ASURINi: "O homem rindo é Maiu". 
Não posso deixar de notar uma certa ingenuidade nas palavras de Anton Lukesch ao insistir na receptividade dos índios em partilhar a "harmonia" da comunidade, atmosfera na qual a tomada de fotografias estava envolta. Em conversa com os Asuriní, quase 45 anos depois, ficou claro que a visão de hoje sobre a presença da câmera dos padres no momento do contato aponta para um sentido um pouco diferente.

Assim como o café amargo, a fotografia foi tolerada como prática inevitável e necessária, inerente ao contato e convivência com os brancos. Em depoimento sobre o encontro com os padres, Marakauá afirmou que a tomada de fotografias foi inicialmente percebida como algo estranho e potencialmente perigoso, mas, quando se deram conta de que fazia parte das atividades dos brancos, os Asuriní teriam aceitado e recuado. Ela conta: "Os tapy'yia [inimigos] estavam tirando foto e o pajé se assustou com a foto. Aí outro disse: "Não é pra se assustar não, é assim que branco vai fazer com a gente". Matuia, índia que traduziu o relato de Marakauá, explica, formulando a frase de outra maneira, que o índio, ao ver que o pajé se assustava com a fotografia, teria dito: "Não vira pajé pra ele [para os brancos] porque nós vamos mudar nossa cultura. É outra coisa agora, temos que nos acostumar". Com a intenção de complementar seu comentário, Matuia comparou a fotografia ao consumo de alimentos industrializados com os quais os Asuriní teriam se "acostumado", como bolacha, açúcar e farinha, dentre muitos outros.

Relatos de outros índios, coletados na ocasião da circulação das fotografias publicadas em Bearded indians..., apontam para outros tipos de entendimentos, mas que partem do mesmo ponto: a presença deste tipo de produção de imagem é aceita pelos Asuriní. Takamuin, em comentário reproduzido a seguir, parece ter compreendido muito bem a função das fotografias tiradas por Lukesch:

Antigamente branco estava tirando fotografia da gente pra dizer que é verdade que a gente estava manso, que eles já conheciam a gente. Ele foi tirando a foto de cada um, aí depois ele foi mostrando as fotos para a Funai. Tirou foto de dente de macaco [kajyja], de miçanga, de panela [japepaí], arco [yvykwasiara], de rede. A gente não tinha nem um pouquinho de coisa de branco, só as nossas coisas. Depois eu não sei 
onde ele levou essas coisas, acho que deixou em Altamira e também levou pra longe. Essa nossa foto eles vendem aí pra fora e dá muito dinheiro pra eles, com esse dinheiro que eles compraram muitas coisas pra nós".

0 relato de Takamuin refere-se claramente a alguns objetos: colares, panelas e miçangas, que ele acabara de ver retratados nas fotos dos padres, conforme as imagens seguintes (imagens 12 e 13). 0 índio, que desde o primeiro trabalho de campo confirmou a narrativa acerca da agência patogênica da fotografia, diante das imagens "reais" (e não da memória que tinha das fotografias), produz uma reflexão e apresenta um discurso completamente diferente do que me havia fornecido anteriormente. A ênfase sobre a agência perigosa da foto não tem espaço e ele reforça que "[...] a foto hoje não faz mais mal", e uma das justificativas é que "[...] também, Padre Antônio já morreu". Ele remarca que as fotografias não tinham agência por si só, estando submetidas às intenções de alguém, no caso, o padre Antônio. Takamuin fez uma defesa do trabalho do missionário argumentando que ele foi muito bom com os Asuriní pois "deu as coisas" para eles, referindo-se ao grande volume de presentes que teria sido distribuído.

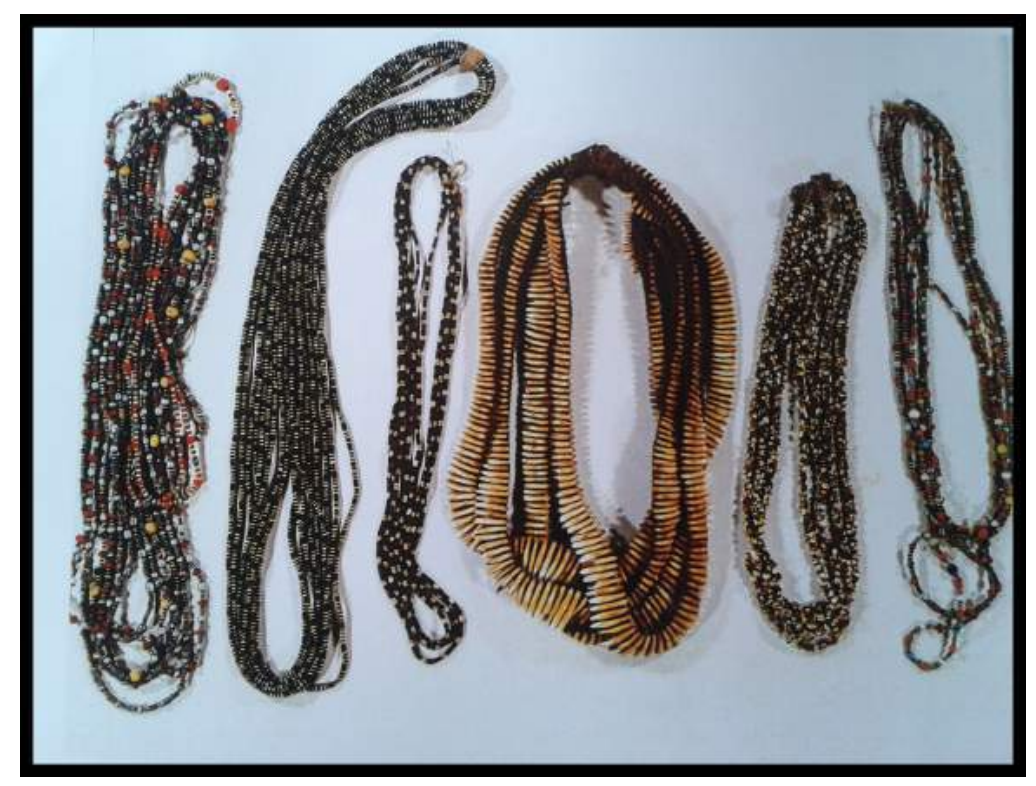

Imagem 12

"Padrão de arte asuriní: colares típicos".

Foto e legenda de A. Lukesch, 1976, p. 108. 
Na imagem anterior, diferentes colares; destaque para o segundo da esquerda para a direita, feito do coco e osso de mutum, chamado mombaka, e o quarto da esquerda para a direita, feito de dente canino de macaco, chamado kajyja.

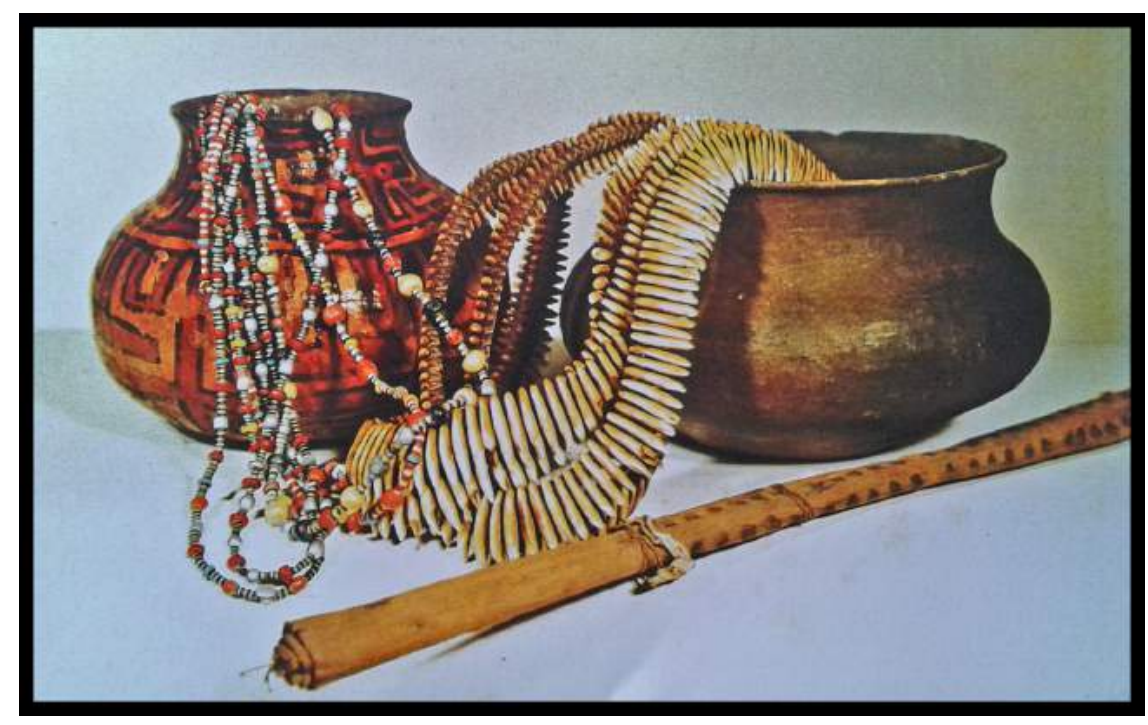

Imagem 13

"Recipiente policromado de água, pote para cozinhar, colares selecionados e cigarro asuriní". Foto e legenda de A. Lukesch, 1976, p. 108.

Panelas yava e japepaí, charuto (petym), kajyja e colares de miçanga.

É digno de nota que a venda das fotografias apareça no comentário de Takamuin, pois traduz uma reflexão recente que ronda os Asuriní, e que os fazem continuar desconfiando do trabalho realizado por pesquisadores e fotógrafos que visitam a aldeia. Ainda que a questão seja importante e traduza preocupações e riscos envolvidos na produção de imagens, incluindo aí as videográficas e fotográficas, ao mesmo tempo que uma tentativa de controle por parte dos índios desta produção imagética, o que nos interessa aqui é a compreensão de Takamuin de que as fotografias no contato operaram como moeda de troca com os padres: os Asuriní permitiram ser fotografados e, como permuta, ganharam presentes.

A respeito dos presentes na ocasião do contato, tanto os Asuriní como o padre-etnólogo dão extrema relevância a esta forma de troca. Lukesch dedica uma sessão inteira do livro a descrever as estratégias de escolha dos presentes e os momentos em que foram distribuídos. Para os índios, a aquisição dos produtos 
é, talvez, o que mais desejavam, e o que os faz compreender que os brancos tinham vindo em missão amigável.

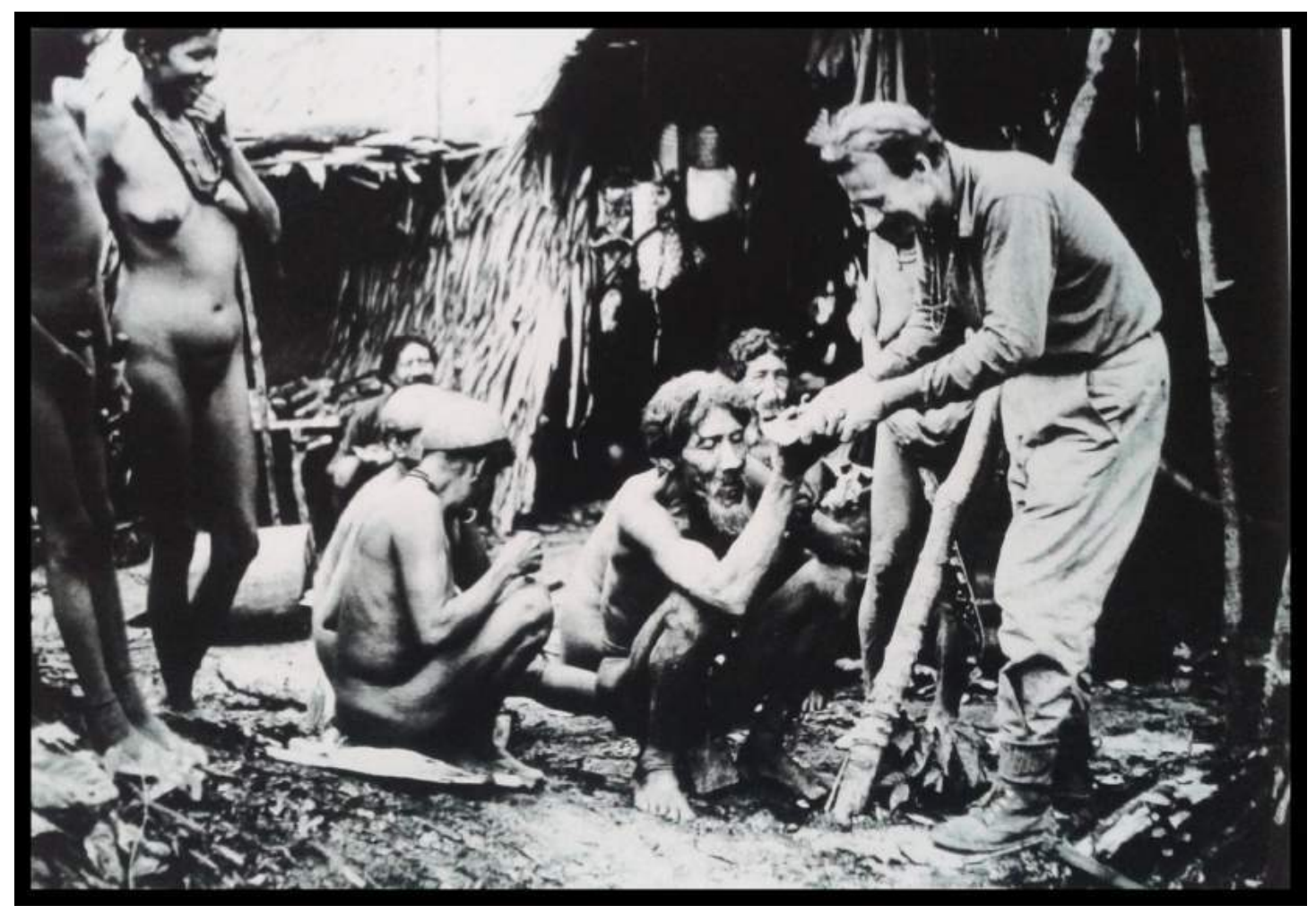

Imagem 14

"O autor distribuindo machados". Foto: K. Lukesch e legenda de A. Lukesch, 1976, p. 50. Identificação asuriní: "Kupen, pai Myrá, que morreu logo depois da partida dos padres".

Era consenso entre os caçadores e gateiros que freqüentemente percorriam a região em que perambulavam os Asuriní que, nos ataques aos brancos, os índios furtavam e roubavam principalmente objetos de ferro como machados, facões, facas e até pregos e agulhas. Para evitar serem roubados, muitas vezes os caçadores escondiam as ferramentas de ferro perto do acampamento e só tiravam do esconderijo quando já haviam se certificado de que não havia índios por perto (Lukesch, 1976, p. 112). Hipólito, um colono (settler) do Paissandu que trabalhou no território asuriní, disse aos padres que os índios "[...] são doidos por tudo quanto é ferro", o que teria sido confirmado por depoimentos de outros regionais. 
Durante a permanência entre os Asuriní, os Lukesch teriam feito, como ele diz, a mesma descoberta a respeito do que chama a "sede de ferro"100: "Nossos presentes como facões, facas de caçar e cavadeira encheram os índios de entusiasmo", ainda que eles tenham se mostrado "calmos e reservados" enquanto aguardavam pelas novidades (Lukesch, 1976, p. 118). 0 autor descreve que, após receber os presentes, os índios imediatamente se afastavam um pouco da aldeia para testar as ferramentas e, em muitos casos, demonstravam ter habilidade no manuseio dos equipamentos. Os Asuriní já possuíam diversas ferramentas de ferro tomadas dos "caçadores civilizados", além de roupas, redes e até miçangas; Lukesch afirma não ter encontrado um único machado de pedra entre os índios do Ipiaçava. Chama a atenção do padre-etnólogo as maneiras criativas empregadas pelos Asuriní para armazenar e carregar as ferramentas, como na imagem 6 que retrata um jovem índio que pendurou o machado ao seu pescoço.

Lukesch tem claro que os presentes são uma estratégia necessária ao primeiro contato e que o oferecimento de bens industrializados demonstra a atitude pacífica dos brancos de uma maneira concreta desde o início (Lukesch, 1976, p. 121). No relato do contato fornecido por Marakauá, após receber muitos presentes, Avona gritou para os outros índios que estavam por perto que eles podiam chamar os parentes pois os brancos "não estavam fazendo nada de ruim com ele". Avona tinha conseguido amansar os brancos e os presentes eram uma prova disso. Dar e receber mercadorias foi a confirmação de que os índios barbados da floresta tropical haviam aceito o contato, tendo sido "pacificados", da perspectiva dos padres, e que os brancos haviam sido "amansados", da perspectiva dos índios.

Embora os relatos asuriní nos informem que os padres trouxeram uma grande quantidade de presentes, Lukesch pondera que teve o cuidado de levar apenas o que já era sabido de que os índios "precisavam" (sobretudo ferramentas de ferro) e sem exagero na quantidade, sob o risco de chegar a "resultados devastadores", como o de fomentar o desenvolvimento de uma "mentalidade de

\footnotetext{
${ }^{100}$ Lukesch retira a expressão de Schaden (1965, p. 169), o que indica o quanto esse tipo de relato é recorrente entre os mateiros, colonos e caçadores que tiveram contato com índios não oficialmente contatados.
} 
pedinte", ou de os índios ficarem com a impressão de que as pessoas civilizadas são obrigadas a "dar-lhes tudo por nada" (Lukesch, 1976, p. 121). Para que isso não ocorresse, o autor defende que os nativos deveriam fazer algo em troca dos presentes, fosse na forma de permuta de bens, ou fosse "performando algum trabalho".

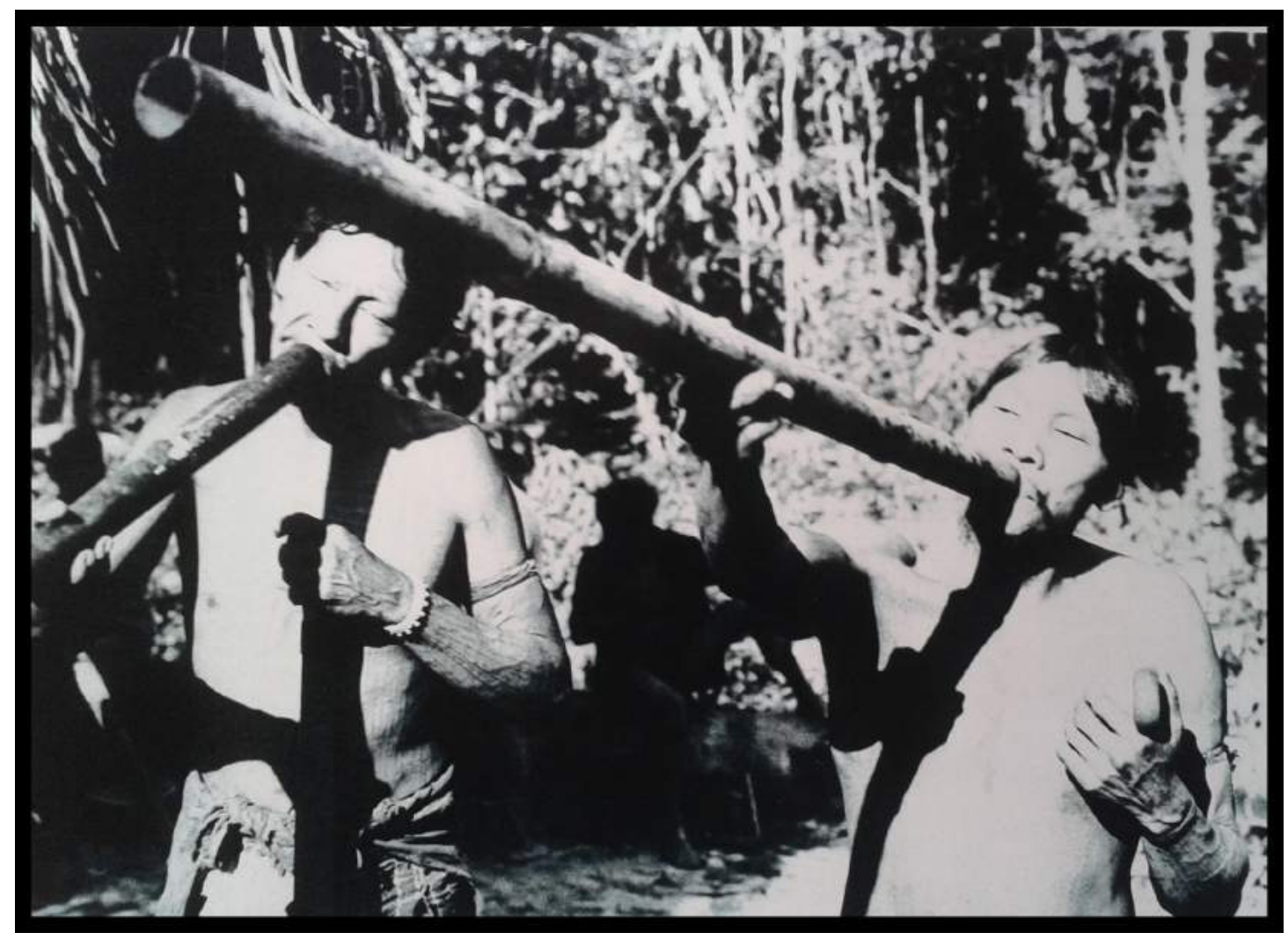

Imagem 15

"Concerto asuriní com clarinetas de bambú". Foto e legenda de A. Lukesch, 1976, p.98. Identificação asuriní: "Tamakigi à esquerda e Mure'yra à direita".

Conhecendo um pouco da história dos Asuriní nos mais de 40 anos de relações intensas com os brancos, posso afirmar que o padre-etnólogo fez uma boa previsão: uma vez feito o contato, o fluxo de mercadorias vindo de fora não mais cessou, e os brancos, detentores e produtores desses bens, são, na visão dos Asuriní, aqueles que devem provê-los. Tal ponto de vista é comprovado pela divisão feita por Takamuin entre quem é "amigo" dos Asuriní e quem não é. Os parceiros e "amigos" seriam aqueles que dão presentes, entre os quais ele inclui alguns pesquisadores, os padres, um missionário evangélico, dentre outros (na 
lista dos que não são "amigos" o índio citou a Funai). A segunda assertiva do padre-etnólogo se refere à performance ritual como moeda de troca com os akaraí (imagem 15), prática corrente até os dias de hoje. Há pelo menos dez anos, desde que acompanho a vida dos Asuriní, eles raramente fazem uma festa do Turé, por exemplo, sem apoio e subsídio dos interlocutores e parceiros de fora ${ }^{101}$.

Já na ocasião do contato, os rituais foram realizados diante da platéia de brancos e como "bem" de troca, e Mure'yra, o índio que até hoje se destaca como líder nos cantos e danças, já aparecia nos anos 1970 com esta atribuição, como demonstra a figura seguinte (imagem 16). 0 mais intrigante - e o ponto que nos interessa aqui - é que, se a performance ritual é realizada em troca dos presentes, não basta apenas assistirem; os brancos sempre querem registrá-la. A presença da fotografia (e do vídeo) na trama e barganha em que estão envolvidos presentes (do lado dos brancos) e performances rituais (do lado dos índios) se verificou muitas vezes depois do contato. Em 1997, um ritual xamanístico foi realizado para ser filmado por Regina Müller e Virgínia Valadão, a pedido dos Asuriní, e, em 2007, eu mesma filmei um ritual para o espírito Apykwara para minha pesquisa, em troca de prover os índios de fumo, carne salgada e outros presentes (Cf. Villela, 2009). A produção de imagens pelos brancos entre os Asuriní - e isso aparece muito claramente na publicação dos padres - é uma forma de troca; faz a mediação entre interesses dos dois lados e quase sempre termina por testemunhar a relação que é marcada pela mise-en-scène dos índios diante das expectativas dos brancos. A fotografia na obra de Lukesch, muito além de documentar como prova e evidência a "descoberta dos índios barbados da floresta tropical", registra este primeiro encontro e as projeções mútuas que são depositadas nesta nova relação que acaba de começar.

\footnotetext{
101 Sejam pesquisadores, membros da empresa que comercializa seu artesanato (Fundação Ipiranga) ou da Verthic, empresa contratada pela Norte Energia para executar ações do Plano Básico Ambiental referente a programas de mitigação de impactos do processo de licenciamento da UHE Belo Monte. Os apoios mais recorrentes são: gasolina para expedições de coleta de matéria-prima para a confecção de instrumentos e objetos, rancho (suprimentos alimentares industrializados), fumo, materiais de pesca e caça, miçanga, dentre outros.
} 


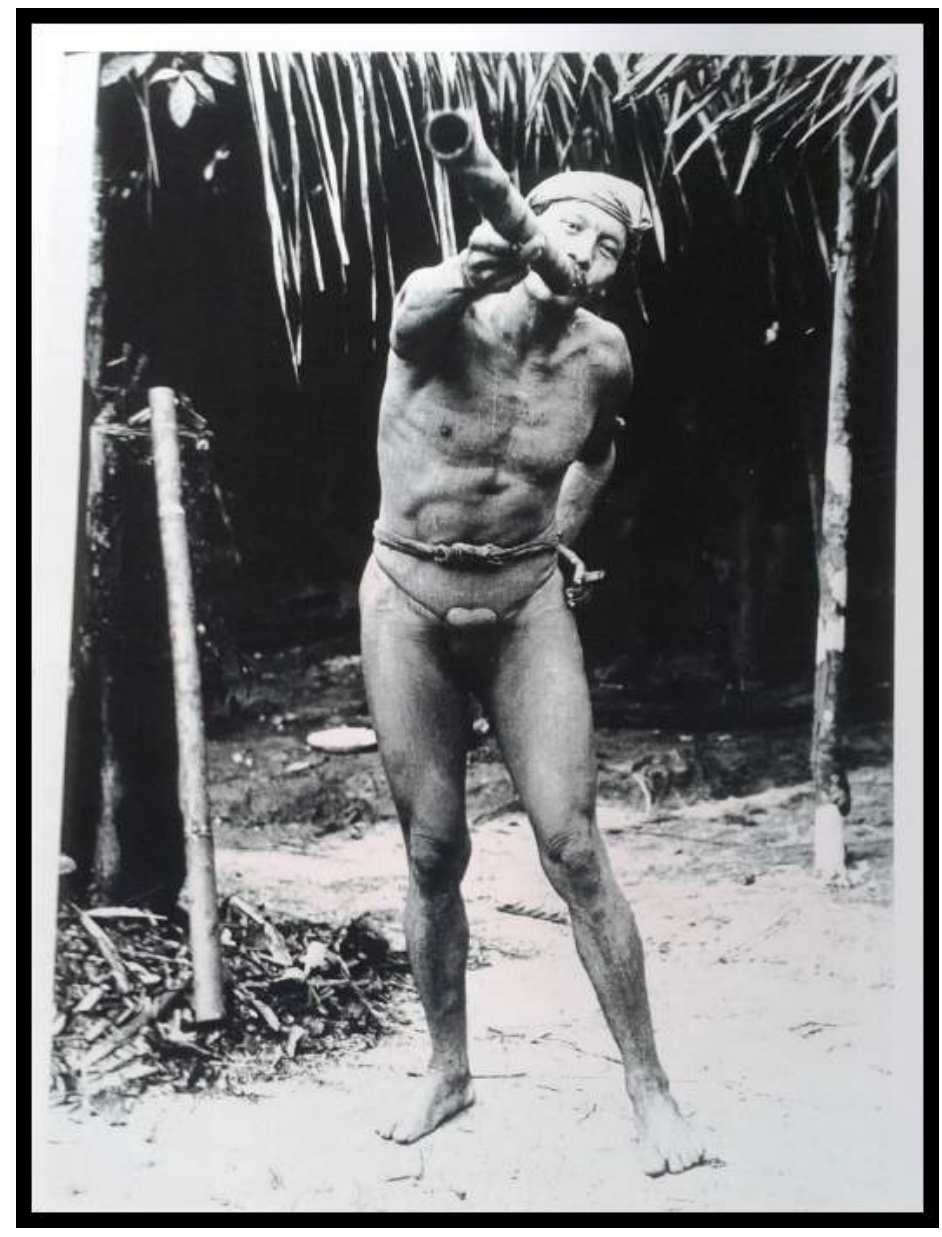

Imagem 16

"O maestro da música e da dança". Foto e legenda de A. Lukesch, 1976, p. 97.

Para finalizar este capítulo, evoco a metáfora do jogo de espelhos cunhada por Caiuby Novaes (1993) ao analisar o complexo mecanismo de construção de imagens de si que uma sociedade, como a bororo que investiga, pode produzir ao conviver com diferentes outros.

Quando uma sociedade focaliza um outro segmento populacional, ela simultaneamente constitui uma imagem de si própria, a partir da forma como se percebe aos olhos deste outro segmento. É como se o olhar transformasse o outro em um espelho, a partir do qual aquele que olha pudesse enxergar a si próprio (Caiuby Novaes, 1993, p. 107).

Se olhar para outro segmento pode transformar o outro em um espelho a partir do qual se constrói uma imagem de si, Lukesch e sua câmera - uma pessoa 
com um "grande olho" - funcionam como um potente espelho para os Asuriní e, ao invés de o espelho apenas refletir a imagem que os índios produzem de si diante deste outro, também captura todo o jogo e o mecanismo de múltiplas projeções. 


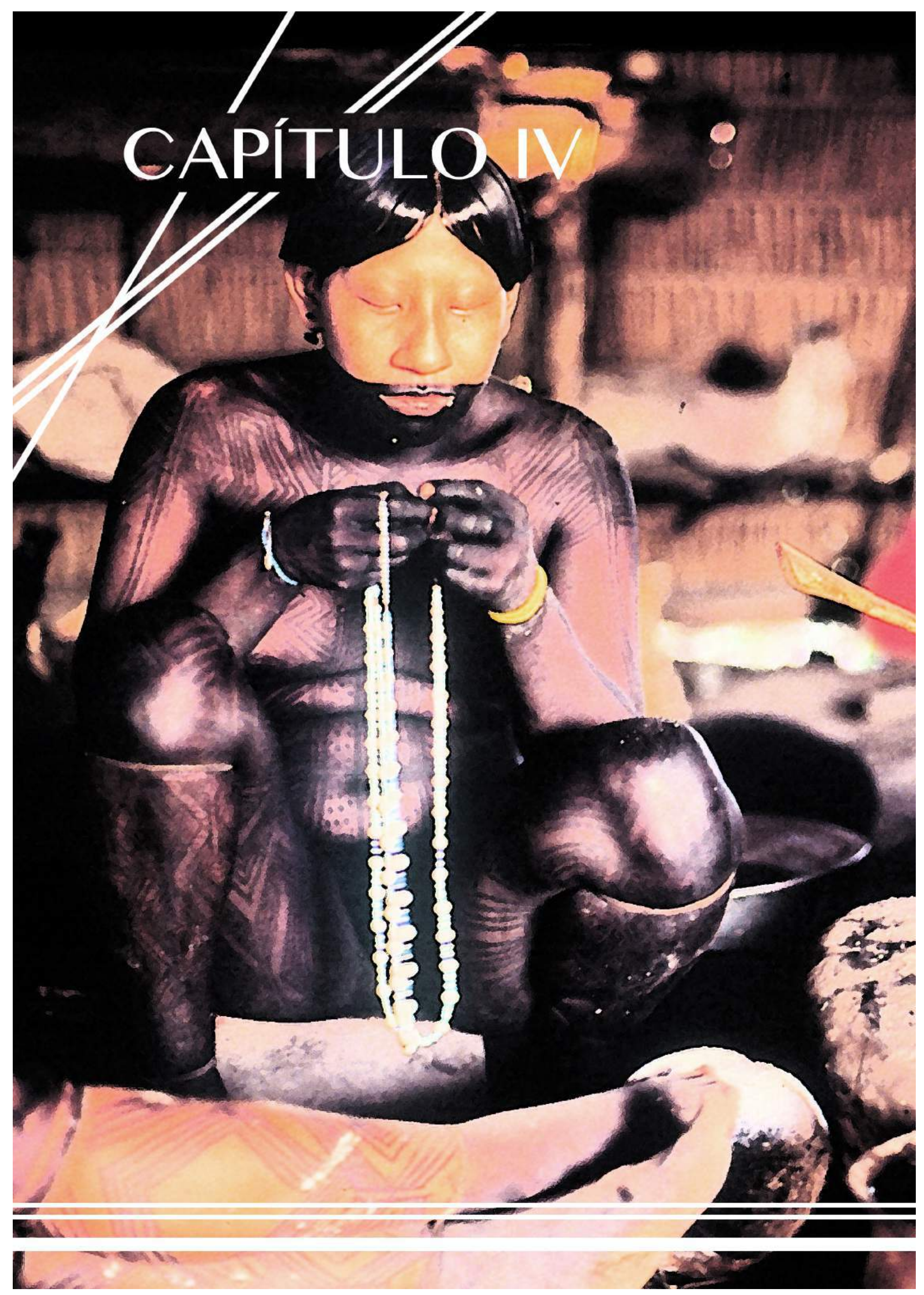




\section{CAPÍTULO 4}

\section{O RETORNO DOS ANTIGOS: FOTOGRAFIAS DE RENATO DELAROLE NA ALDEIA}

\subsection{0 retorno das fotografias como forma de abordagem}

A proposta de circular as fotografias de Renato Delarole entre os Asuriní foi, inicialmente, concebida como um dispositivo que me permitisse refletir sobre o modo como os índios se relacionam com imagens fotográficas atualmente. Da perspectiva indígena, estaria a fotografia, de alguma forma, sob a névoa do perigo e da negatividade, ou seus usos e apropriações atuais apontariam para outra direção? Para além disso, pretendia com essa circulação das fotos construir o encontro etnográfico em torno de uma provocação ${ }^{102}$ : colocar os Asuriní diante de imagens de si e dos seus "antigos". Experiências de campo anteriores, em que levei imagens fotográficas produzidas por mim e também por Delarole, instruíram-me, ainda que de forma não sistemática, a respeito da produtividade do emprego de fotografias em situações de encontro etnográfico ${ }^{103}$.

A experiência de levar para as aldeias o acervo integral de fotografias de Delarole não deixou de se constituir como uma forma de partilhar o conhecimento produzido sobre os Asuriní com eles, tendo em vista que todas as

\footnotetext{
102 Este é o objetivo de Edgar Teodoro da Cunha, Ana Lúcia Ferraz e Rose Satiko Hikiji, (2006), quando propõem aos seus diferentes interlocutores a apropriação do audiovisual. 0 fazer antropológico, neste caso, está orientado a partir de uma proposição e uma provocação que considera, inclusive, o lugar do antropólogo na relação com o grupo.

103 Como observa Maresca (1996), ao tecer uma história do olhar fotográfico na antropologia, imagens possuem o potencial reflexivo em situações de encontro etnográfico e são um meio privilegiado para a compreensão cultural.
} 
imagens foram produzidas no âmbito de pesquisas acadêmicas da antropóloga Regina Müller. Assim como Rouch inclui o retorno de seus filmes aos grupos estudados como forma de criar um diálogo efetivo com as sociedades entre as quais trabalha, indo além do mero feedback (Cf. Cunha, Ferraz e Hikiji, 2006), o retorno de imagens aos Asuriní foi pensado como uma forma de partilhar com o grupo a produção de representações a seu respeito, e, sobretudo, de criar situações em que eu pudesse observar a forma como eles se apropriam dessas imagens segundo uma lógica própria.

A recepção asuriní às imagens foi marcada por interesse e curiosidade, principalmente dos velhos, que se mostraram bastante disponíveis para o trabalho com as fotografias. Sessões de manuseio, exame, observação e deleite com as fotos foram realizadas nos espaços privados dos núcleos residenciais e nos espaços externos a eles associados, como cozinhas, pequenos pátios e casas de farinha. Com algumas famílias foi possível realizar um trabalho continuado, o que possibilitou a criação de um ambiente de confiança e intimidade, atmosfera que favoreceu a enunciação de relatos pessoais, evocados pelas fotos dos familiares.

Sessões de fotografias constituíram bons pretextos para conversas sobre diversos aspectos da vida social asuriní. Em razão da riqueza de detalhes que apresentam, fotografias estimularam a curiosidade de jovens - entre os quais me incluo - a respeito de vida ritual, produção de objetos e utensílios, processamento de alimentos e, sobretudo, acerca das relações de parentesco que iam sendo estabelecidas com as pessoas presentes nas imagens. A densidade de informações e descrições que me eram fornecidas em pouco tempo, aliada à disponibilidade dos índios em explicar o que estava retratado nas imagens e em responder às minhas perguntas, lançou luz para o potencial da fotografia como instrumento de transmissão de conhecimentos, do qual muito me beneficiei.

Cheguei ao campo com a proposta metodológica de uso das fotografias do acervo de Delarole em aberto. Embora tivesse uma série de questões em mente e algumas propostas de atividade com o acervo, não me preocupei em levar um plano de trabalho fechado, pois acreditava que deveria, primeiramente, observar a resposta asuriní às imagens. Como já se mencionou, minha intenção inicial era 
criar situações de interação dos Asuriní com as fotografias. Sabia, de antemão, do perigo associado às imagens de pessoas que já morreram e, respeitando as regras e limites apresentados pelos Asuriní, pretendia investigar a existência ou não de tabus relacionados aos retratos dos mortos. Ademais, tinha a expectativa de realizar um trabalho um pouco mais aprofundado com os índios interessados, de forma a selecionar, dentre todo o acervo, as fotografias mais significativas e coletar relatos, propondo que, ocasionalmente, organizassem parte do acervo segundo parâmetros próprios.

Para uma possível organização do grande volume de imagens, uma referência metodológica importante, consultada antes da viagem de campo, foi a pesquisa de Fabiana Bruno. Em sua tese de doutorado, intitulada "Fotobiografia, por uma metodologia da estética em antropologia" (2009), a pesquisadora aposta em uma proposta metodológica que confere prioridade e confiança ao trabalho das imagens. A partir de fotografias de memórias de cinco pessoas idosas da cidade de Jaguariúna, Bruno realiza um percurso metodológico de natureza visual trabalhando com conjuntos fotográficos compostos por 20, 10 e 3 fotografias de cada um dos colaboradores da pesquisa. Diz a autora: "Por serem carregadas de memórias, elas, as imagens, puderam, diferentemente do verbal, 'refletir' e 'pensar', 'redescobrir', e 'esquecer', a memória de pessoas idosas" (p. vii, 2009). 0 trabalho de Bruno me iluminou metodologicamente com propostas de seleção e organização de imagens. No entanto, a minha proposta de trabalho tinha, de início, uma diferença de orientação em relação ao que ela propunha. Embora pretendesse dar confiança ao trabalho com as imagens, não me interessava pesquisar como as fotografias "pensam", "refletem" e "esquecem" a memória de pessoas, mas como imagens agem (Cf. Gell, 1998) "provocando", "despertando", "originando", "ativando" efeitos, memórias e reflexões nas pessoas.

Não se tratava de pensar a relação dos Asuriní com quaisquer tipos de imagens fotográficas, mas de propor o confronto com imagens de si e de seus "outros", incluindo aí os vivos e os mortos. Pessoalmente, trabalhar com o conjunto fotográfico de Delarole era uma espécie de retorno a um material sobre 
o qual eu me debruçara extensivamente há cerca de dez anos, na ocasião da realização de um trabalho que marcou a minha entrada no campo.

Em 2006, recém-saída da graduação em Ciências Sociais na Unicamp, eu trabalhara no edital "Mapeamento, Documentação e Apoio ao Patrimônio Cultural Imaterial" do Iphan. O projeto, ao qual já fiz menção em capítulos anteriores, teve como objetivo tratar, digitalizar e organizar o acervo sobre 0 patrimônio imaterial asuriní, incluindo não apenas fotografias mas também vídeos em super-8, Betacam e VHS, além de material de áudio em fita K7 e em rolo obtidos por gravador Nagra, reunidos nos últimos 30 anos pela pesquisadora Regina Müller. Na época, eu preparava um projeto de mestrado e as fotografias foram o meu primeiro acesso aos Asuriní, juntamente com leituras bibliográficas que realizava. 0 contato extensivo com negativos, positivos, slides e ampliações me possibilitou conhecer os índios pelas imagens e me sentir, de certa forma, íntima de alguns deles, antes mesmo de ir ao campo. Por intermédio do contato direto com as fotografias passei a reconhecer rostos, saber nomes próprios e identificar índios em diferentes fases de suas vidas. Portanto, o trabalho com este acervo tem, também para mim, uma dimensão de retorno, de volta a um material conhecido, agora de forma mais sistemática e a partir da formulação de questões num enquadramento de pesquisa.

Maio de 2015. Cheguei à aldeia Koatinemo com pouco mais de 750 fotografias impressas em tamanho $15 \mathrm{~cm} \mathrm{x} 21 \mathrm{~cm}$, em papel fotográfico fosco e laminado. Rapidamente a notícia de que tinha trazido fotografias dos "antigos" se espalhou pela aldeia e eu iniciei, então, as sessões nos âmbitos dos diferentes grupos domésticos. A aldeia toda quis ver as imagens, o que me levou, durante algumas semanas, a passar os dias inteiros fazendo trajetos entre as residências com as fotografias nas mãos. 0 mesmo se repetiu na aldeia Ita'aka, com o detalhe que esta aldeia é menor, o que demandou menos tempo de trabalho.

As imagens de Delarole funcionaram como objetos disparadores de memórias. Vendo as fotos, os Asuriní não me falavam sobre o fotógrafo ou as condições de tomada das fotografias, não tentavam me fornecer coordenadas espaço-temporais em que as fotos foram tiradas, nem comentavam os objetos retratados ou as ações realizadas no momento do registro, a não ser que eu os 
questionasse a respeito. Ao verem as fotografias, imediatamente identificavam as pessoas retratadas e faziam questão de situá-las na trama do parentesco. Alguns, vendo imagens de si quando novos, reconheceram-se e comentaram experiências do passado. Outros, essencialmente os velhos, recordaram de esposas e esposos, ao verem retratados ex-cônjuges que já faleceram, e produziram relatos carregados de afeto e saudades. Entre os que viveram no tempo em que Delarole fotografou, as fotografias funcionaram como detonadores de memória, em que a experiência mais marcante consistiu na possibilidade de avivar feixes de relações com parentes e tornar presentes vínculos de pertencimento.

Ana Cecília Bueno, em sua tese de doutorado sobre parentesco e memória entre os Manoki e Mỹky, argumenta que o parentesco, como é sabido, é socialmente construído e se constitui enquanto tal a partir de um arcabouço de informações compartilhadas entre as pessoas que são feitas parentes. Neste momento, a relação entre parentesco e memória é posta, uma vez que ele parece sempre depender dessas informações, ou conhecimentos, do que veio de um tempo - imediatamente ou não - pretérito. Ela vai dizer que a memória familiar, ou genealógica, desempenha, nesse sentido, um importante papel na estruturação do tempo doméstico e da coletividade, em algumas sociedades. Nesses casos, o tempo não é organizado em função de fatos históricos, mas das lembranças de momentos significativos e marcantes na lembrança familiar. Nascimentos, alianças, mortes, aquisição de terras, entre outros, são eventos que marcam o tempo e se tornam referências compartilhadas (Bueno, 2015, p. 9). Embora não pretenda utilizar as fotografias para reconstituir a rede genealógica, tarefa a que se dedica Bueno, devo admitir que os Asuriní de certa forma o fizeram, já que uma das reações diante das imagens foi a de identificar as pessoas retratadas e situá-las na trama de relações via parentesco.

Fotografias atuaram de forma fecunda na produção de relatos, expressão das memórias ativadas. Este uso da fotografia não é, de longe, uma novidade; diversos estudos empregaram a fotografia aliada a registros orais. Já em 1967, John Collier Jr. dedicou um capítulo de sua obra Antropologia visual: a fotografia como método de pesquisa (1973) ao uso de imagens fotográficas durante entrevistas com indivíduos dos grupos pesquisados, focando as contribuições 
que poderiam trazer para os estudos antropológicos. A historiadora Miriam Moreira Leite (2001[1993]) assinalou em sua obra que, ao olhar uma imagem, não é ela que se vê, mas sim outras que se desencadeiam na memória. A cientista social Olga Von Simson (2005) constatou que seus depoentes, no caso da sua pesquisa do samba paulista, utilizavam fotografias como recursos detonadores de memórias, e, além de as fotografias enriquecerem a narrativa, também davam mais segurança ao processo de rememoração. A possibilidade de uso da fotografia como enriquecedora de registros orais a coloca, na maior parte dos casos, como secundária. Uma diferença crucial entre estas abordagens e a que empreendi consiste no fato de que, neste trabalho, fotografias são empregadas como método de abordagem para investigar justamente a relação dos índios com a fotografia, sendo, ela, método e tema do estudo. A questão que a fotografia coloca para os Asuriní reside justamente no que ela faz. Portanto, a capacidade de acionar memórias, artifício metodológico para alguns, é um problema central que interessa a este trabalho ${ }^{104}$.

Sobre a forma de abordagem dos relatos produzidos a partir das memórias disparadas pelas fotografias, é importante ressaltar que não pretendi utilizar as narrativas para obter pistas que me permitissem reconstituir o passado - ou uma "história asuriní", ainda que pessoal e familiar do tempo em que viviam na aldeia Koatinemo Velho, local de residência dos índios no período em que Renato Delarole fotografou. Embora o trabalho mental de reconstituição fosse quase intuitivo; afinal, como pesquisadora, eu precisava de certos parâmetros temporais para entender os relatos: saber quando determinado índio faleceu, quem era o chefe de posto na ocasião, quem residia na mesma casa, quem estava casado com quem - o que poderia ter rendimento, se conjugado aos dados da etnografia de Müller (1993) -, não era a este tipo de abordagem a que os relatos se prestavam.

Como dar conta, então, das potentes memórias acionadas e enunciadas? Um importante insight ocorreu numa tarde em que eu, pela terceira ou quarta

\footnotetext{
104 Se o potencial de despertar memórias pode ser verificado entre outros campos de estudo que empregam a fotografia aliada a relatos orais, a ênfase asuriní em sua agência aponta justamente para o fato de que ali fotografias entram num regime de imagem muito específico. Tal preocupação permeia as questões a partir das quais se constrói a escrita do primeiro capítulo desta tese, não sendo necessário nos atermos a elas.
} 
vez, debrucei-me, juntamente com Mure'yra, a conhecer algumas de suas esposas que freqüentemente víamos retratadas nas fotografias. Mais de uma dezena de fotos traziam diferentes mulheres com quem o índio foi casado, às quais ele se referia, sem distinção, pelo termo jeremiriká, "minha esposa". 0 índio também não fornecia informações que permitissem que eu me situasse a respeito do momento e da seqüência dos casamentos. As memórias das garemiriká (esposas dele) eram sobrepostas, como se ele as tivesse em tempo presente, todas de uma única vez. Memórias carregadas de afetos. Ele se demorava em cada uma dessas imagens; um leve brilho nos olhos e o pequeno esboço de um sorriso me faziam entender o que ele não dizia: Mure'yra estava emocionado em ver suas "esposas" retratadas. Eu me deixava conduzir pelas reações que ele tinha mas, ao mesmo tempo, fazia esforço para compreender as complexas tramas de parentesco com cada mulher e situar temporalmente os casamentos. Ficou claro que o impulso de entender e ordenar os matrimônios de Mure'yra num tempo-espaço eram trabalho em vão.

Marakauá, vendo minha ânsia em situar quem era quem e quando foram contraídos os matrimônios, riu e disse apenas: "[..] é por que Mure'yra teve muita mulher". O comentário da índia me ajudou a perceber o trabalho da memória que estava sendo realizado. Ela me indicava que as lembranças pessoais dos enlaces com as esposas, acionadas pelas fotografias, deviam ser tomadas mais como um processo de "criação de uma realidade", em que as mulheres conviviam no mesmo espaço-tempo, o da lembrança do presente, do que como um documento e testemunho que me auxiliariam a reconstituir o passado. Por vezes, os Asuriní realizaram comentários comparativos entre o que viam nas imagens e o momento presente, como se verá, principalmente a respeito da forma com que eram e com que são realizadas as alianças matrimoniais. Os relatos que transcrevo neste capítulo, especialmente relacionados a lembranças de cônjuges, são uma tentativa de trazer um pouco da experiência vivida em campo.

Se as fotografias agiram como gatilhos para os disparos da memória, levar mais de 700 imagens funcionou como uma rajada de tiros em seqüência, gerando feixes de lembranças combinados e sobrepostos que se teciam de forma ativa, plástica e criativa. Os fios em que se teciam fotografias e memórias eram feitos da 
matéria do afeto e da emoção, e era isso que os Asuriní estavam me mostrando ao me indicar que as imagens significativas eram as de seus entes queridos, principalmente maridos e esposas. Com Marakauá e Mure'yra, pude verificar tanto a maneira em que eles empregaram as fotografias para refazer laços e vínculos de parentesco, ao elaborar sua seleção do acervo - a que chamo de "álbuns", em razão da presença massiva de familiares -, como também entender que as fotos mais caras a eles eram as que traziam lembranças de experiências partilhadas com ex-cônjuges.

Existe uma certa relação entre o que as fotografias evocaram entre os Asuriní e os retratos de família abordados por Miriam Moreira Leite (2001[1993]). O entusiasmo com que as fotografias dos "parentes" foram recebidas pelos índios nos faz lembrar do fascínio que exercem os retratos dos álbuns de família nos grupos em que Moreira Leite pesquisou. A autora comenta que a atração teria sido observada por Bourdieu e seus discípulos quando consideraram o álbum de família um "monumento funerário freqüentado assiduamente". Dubois 2014[1990], ao dar ênfase à unicidade referencial que literalmente se propaga por contato e pelo jogo da contigüidade material entre imagem e pessoa retratada, cita os retratos de família, ao comentar os usos que tendem a atribuir à foto uma força particular, algo que faça dela um verdadeiro objeto de crença, para além de qualquer racionalidade, de qualquer princípio de realidade. Os álbuns de família, guardados e cultivados como uma "múmia dentro de uma caixinha", são abertos com emoção "[...] numa espécie de cerimonial vagamente religioso, como se tratasse de convocar os espíritos" (Op. cit., p. 80). Neste tipo de álbuns, fotos são como traços físicos de pessoas singulares, que guardam relações singulares com aquele que olha as imagens. Dubois fala em verdadeiro culto a fotos de família, e, nos álbuns, como objetos fúnebres, semelhantes aos kolossói - substitutos do morto na Grécia Antiga analisados por Vernant (1990[1973]).

Se o culto aos álbuns de família como objetos fúnebres semelhantes aos kolossói nos aproximaria dos gregos na Antigüidade (e dos índios), a elaboração dos "álbuns" asuriní muito pouco se avizinham às nossas práticas de guardar a memória dos parentes via fotografias. Embora tenha sido salutar ver os mortos 
nas imagens, repito, por se tratarem de mortos recuados no tempo, guardar imagens ou objetos do morto não é uma prática corrente pois, após a morte, tudo o que lembra o morto deve ser destruído. 0 emprego de fotografias para lembrar dos "parentes" não é uma prática asuriní, muito pelo contrário, foi a reação e o efeito a uma provocação.

0 método de pesquisa de campo proposto, espécie de "provocaçãoobservante", consistiu em circular as imagens e depois observar o que a fotografia faz, o que ela engendra, de que modo atua, o que efetua, como age, procede, pratica, processa e o que aciona. E o que ela fez, essencialmente, foi trazer os "antigos" pela mão das memórias a eles vinculadas. Durante alguns dias, a aldeia asuriní se ampliou, vivemos envoltos da presença dos "antigos", não a presença espectral, nem a presença em carne e osso, mas a presença em pensamento, lembrança e imagem, via fotografia e memória. Relatos e fotografias ${ }^{105}$ neste capítulo nos permitem acessar a presença e o retorno dos "antigos" nas aldeias provocados pela circulação das imagens de Delarole.

Antes, porém, de chegarmos propriamente na agência das fotografias por intermédio da apresentação das seleções do acervo (os "álbuns") e das memórias dos velhos, um bom percurso será percorrido. Dedico a próxima seção a apresentar o acervo fotográfico de Delarole e o contexto de sua produção, e em seguida passo a breves comentários em relação à recepção asuriní.

\subsection{Contexto e produção das fotografias}

O acervo fotográfico de Renato Delarole

O conjunto de fotografias de Renato Delarole produzidas entre os Asuriní do Xingu compreende pouco mais de 750 imagens, originalmente produzidas em suporte analógico. São cerca de 450 slides e 300 negativos, contatos e ampliações PB. Nos rolos de filme, estão retratados variados aspectos da vida dos Asuriní do

\footnotetext{
${ }^{105}$ Analiso as fotografias apresentadas no corpo do texto, e as imagens exibidas nas pranchas servem para reforçar o que as do corpo do texto apontam, à exceção das pranchas 5 e 6, que trazem a seleção de Mure'yra e de Marakauá do acervo, que se encontram reproduzidas apenas nas pranchas.
} 
Xingu entre 1977 e 1986, período em que o fotógrafo esteve entre os índios. Dentre todo o acervo, uma ênfase especial é dada aos temas do xamanismo e arte gráfica, tópicos de pesquisa da antropóloga Regina Müller, a quem o trabalho fotográfico de Delarole entre os Asuriní sempre esteve atrelado. Por meio de Müller, Renato é introduzido no campo e, em companhia dela, realiza todas as viagens, inclusive com permanência de dois longos períodos de dez meses, em 1978 e 1979.

Em 2006, as fotografias foram organizadas e digitalizadas pelo já citado projeto Iphan. A iniciativa é de Müller, que deteve o acervo até então, e o trabalho foi realizado juntamente com uma equipe do Instituto de Artes da Unicamp e do Museu de Arqueologia e Etnologia, MAE - USP. As imagens em suporte original foram doadas ao Museu do Índio da Funai, sediado no Rio de Janeiro.

Idas e vindas: o percurso de Renato Delarole entre os Asuriní

Renato Delarole chegou ao Posto Indígena Koatinemo, situado no igarapé Ipiaçava, afluente do Xingu, em abril de 1977. Com a sua Pentax e sem ter completado 20 anos de idade, vinha acompanhando a antropóloga Regina Müller. Desde a experiência com a câmera dos padres-etnólogos em 1971 até a data da chegada de Delarole, os Asuriní conheceram outros fotógrafos, tanto amadores como profissionais. Alguns exemplos: René Fuerst, etnólogo e fotógrafo suíço, esteve entre os Asuriní em 1972, e Vincent Carelli, documentarista e criador do projeto Vídeo nas Aldeias, residiu junto aos indígenas entre 1973 e 1974, ocasião em que integrou o quadro de funcionários da Funai na função de chefe do posto indígena. Em 1976, foi a vez do fotógrafo belga Jacques Jangoux ${ }^{106}$ visitar a aldeia nas margens do Ipiaçava.

A acompanhante de Jangoux foi a antropóloga Regina Müller, que, pela primeira vez, viajou ao encontro dos Asuriní. Müller aproveitou a oportunidade

\footnotetext{
106 As fotos de Jacques Jangoux, bem como as de René Fuerst e Vincent Carelli, não estão acessíveis; apenas algumas podem ser visualizadas no verbete Asuriní do Xingu da Enciclopédia dos Povos Indígenas do ISA, http://img.socioambiental.org/v/publico/asurini-do-xingu/.
} 
de ter sua viagem custeada por Jangoux - já que a Funai exigiu que o fotógrafo estrangeiro ingressasse em Terra Indígena acompanhado de antropólogo - para formular um projeto de pesquisa. Dando continuidade ao tema de estudos da pintura corporal, que inicialmente realizara entre os índios Xavante no âmbito de sua pesquisa de mestrado (Cf. Müller, 1976), Regina Müller inicia pesquisa de doutorado na Universidade de São Paulo - USP107 sob orientação da Profa. Dra. Lux Vidal. Em 1977, é Delarole que a acompanha aos Asuriní, incumbido de registrar a investigação sobre pintura corporal e arte gráfica.

A primeira viagem de Renato Delarole com Regina Müller aos Asuriní aconteceu entre os meses de abril e maio de 1977. Menos de um ano depois, voltam, em março de 1978, desta vez para uma longa estadia. Durante os anos 1978 e 1979, antropóloga e fotógrafo permaneceram quase que todo o tempo residindo no Posto Indígena Koatinemo, nas margens do igarapé Ipiaçava, na aldeia do Koatinemo Velho; retornaram para São Paulo apenas nos meses de janeiro e fevereiro de 1979. No entanto, a motivação da estadia não foi a pesquisa acadêmica, mas o envolvimento em ações indigenistas ligadas à saúde, dada a situação alarmante que testemunhavam. Entre surtos epidêmicos, falta de assistência de saúde por parte do órgão indigenista oficial e práticas tradicionais de abortamento, assistiram ao agravamento do processo de depopulação do grupo indígena.

Em 1976, a população Asuriní somava 60 pessoas; em 1977, 56. Entre 1971, o ano do contato, e 1977, a população havia diminuído sensivelmente, com índices de mortalidade chegando a $20 \%$ e os de nascimento, a 0,05\%. Em vista dessa situação, Delarole se envolveu com o "Projeto de Recuperação dos Asuriní do Koatinemo", implantado pela Funai em 1978 sob coordenação de Regina Müller. 0 projeto pretendeu assegurar a assistência médica permanente e realizar pesquisa interdisciplinar (medicina-antropologia) para melhorar a adequação da medicina científica às formas de curar tradicionais, além de propor uma ação de saúde adequada ao contexto da sociedade recém-contatada.

\footnotetext{
107 Tratou-se do doutorado em antropologia sob a orientação da Profa. Dra. Lux Vidal. A pesquisa, "De como cincoenta e duas pessoas reproduzem uma sociedade indígena: os Asuriní do Xingu", foi defendida em 1987 na USP, SP.
} 
Simultaneamente à sua participação nas ações indigenistas, Renato Delarole continuou a fotografar.

Após regressar da longa permanência entre os Asuriní, Delarole ficou mais de seis anos sem viajar à Terra Indígena, voltando apenas em julho de 1986 para uma estadia rápida com o objetivo de documentar a situação dos Asuriní e avaliar o projeto de saúde iniciado em 1978. As ações de avaliação da situação dos Asuriní e a documentação realizadas em 1986 fizeram parte do "Project of health recuperation for the Asuriní indians of Koatinemo (Brazil)", no qual colaboraram Regina Müller, Renato Delarole e Walter Labonia Filho. A iniciativa foi financiada pela IWGIA - International Work Group for Indigenous Affairs, e pelo Ministério das Relações Exteriores da Dinamarca.

Desde sua última viagem em 1979 muita coisa havia mudado; inclusive, a partir de 1985, os Asuriní passaram a residir na aldeia Avasikirera, nas margens do rio Xingu. Em 1982, os Asuriní chegaram a um patamar mínimo de 52 pessoas; nesta ocasião, um novo projeto de assistência ao grupo foi implantado pela Funai, sob responsabilidade da mesma antropóloga que havia coordenado o projeto em 1978. Com assessoria do Cepam - Centro de Estudos e Pesquisas em Antropologia Médica, o projeto visava dar continuidade à assistência prestada ao grupo Asuriní, com controle sobre o nível de saúde indígena, com ênfase no combate à tuberculose e vigilância sobre outras ocorrências de moléstias. Do ano de sua implantação em diante, a população Asuriní passou a crescer progressivamente. Hoje a população Asuriní conta com 194 pessoas.

\section{Renato - fotógrafo na aldeia}

A câmera de Renato Delarole registrou diversos aspectos da vida asuriní. Dentre os temas predominantes, destacam-se a confecção de objetos da cultura material (cestaria, cerâmica, algodão, pintura corporal), a vida ritual nos Turés, Tauvas e marakás, a construção de diversas tavyve (casa grande), atividades de subsistência como a caça, a pesca e a produção de farinha de mandioca, além de pequenas cenas cotidianas como banhos no rio, refeições coletivas e curtas 
expedições na mata. Além disso, é notável a quantidade de retratos registrados, a maioria imagens posadas de índias e índios pintados de corpo inteiro ou da cintura para cima, ressaltando a exuberância dos diversos motivos gráficos.

Sendo a câmera fotográfica um objeto relativamente recente na vida asuriní e dado o seu potencial perigoso, poderíamos crer que a presença constante de um fotógrafo causaria problemas à vida aldeã. Entretanto, segundo afirma Regina Müller ${ }^{108}$, Renato Delarole nunca passou por nenhuma situação inconveniente; a antropóloga continua:

[...] mas os Asuriní, também, eram um contato muito recente. Tinha a língua e tinha um certo desconhecimento do que era aquilo. Eu não lembro se a gente levou fotos depois, provavelmente a gente deve ter levado pra eles, pra eles verem [...] porque era uma relação muito, de afeto, a comunicação verbal era muito pouca, era aquele básico da língua e alguns jovens, a Kuipiuna, mãe da Apyrakamy, que era muito boa intérprete, a Matuia também falava razoavelmente o português.

Na rápida passagem do fotógrafo Jangoux pelo Posto Indígena em 1976, os Asuriní teriam implicado com o uso que ele fez do flash. Müller, que já havia notado uma certa resistência dos índios em permitir uso de iluminação artificial e flash durante os rituais no período noturno - devido a uma provável interferência na relação dos xamãs com os espíritos - lembra que, num dos dias em que fotografava, o flash de Jangoux parou de funcionar: "Aí eu pensei 'que bom, os próprios espíritos deram conta de cuidar'". Na ocasião em que o fotógrafo foi obrigado a abandonar o uso do flash, Müller chegou a advertí-lo: "Eu acho que os espíritos não estão querendo deixar você fotografar".

Com Renato foi diferente, segundo Müller; nunca houve nenhum problema, muito embora ela não se lembre de Delarole ter utilizado flash - o que é facilmente comprovado pelo fato de todas as fotografias do acervo terem sido tiradas durante o dia. 0 único momento recordado por Müller em que o fotógrafo utilizou luz artificial foi na ocasião de algumas filmagens em super 8, quando eles usaram um refletor para iluminar o ritual maraká para o espírito Arapoá, que

108 Em entrevista concedida no dia 1ํ de maio de 2015 em Campinas - SP. 
acontecia no período noturno, o que, segundo ela, não causou incômodo nem perturbação ao andamento das atividades rituais.

É possível que a longa permanência de Delarole entre os Asuriní tenha contribuído para o seu aprendizado em relação aos momentos em que a fotografia é desejada e aos momentos em que não é bem-vinda. Do mesmo modo, a convivência certamente contribuiu para a naturalização da presença da câmera por parte dos índios - o que pode ser constatado quando olhamos as imagens contendo poses e sorrisos, denotando espontaneidade e confiança ou em situações em que parecem simplesmente ignorar a presença do fotógrafo.

Todos os índios com quem conversei, que eram jovens ou adultos durante a permanência de Delarole no Posto Indígena Koatinemo, lembram-se da sua figura; no entanto, apenas os que conviveram mais intensamente com ele é que se recordaram de histórias e quiseram contá-las. As memórias abordam a convivência cotidiana e intensa e os índios raramente mencionaram sua atividade como fotógrafo. Apebu disse se lembrar "[...] de um bocado de coisas [...] eu pescava com ele. Ele é bom de peixe, não sei agora". Takiri, que parece ter tido um convívio mais acentuado com Renato, recorda: "Ele morava junto no Koatinemo Velho. Morava eu, Tara, Regina e ele. Lá tem morrinho alto. Botá o nome de casa de Ita'aka porque tem pedra lá. Morava numa casinha agieté109. Carrega palha, pau [pra fazer a casa]. Lá é bonito, a pista [de pouso] ficou perto, a casa do lado". Takiri, de forma espirituosa, trouxe à memória outras lembranças: "Ele trabalhava muito comigo, ia caçar, morava junto comigo. Eu andava junto com ele. Ele comprou motor pra mim, eu pescava com ele; aí nós fomos no mato, eu matei veado e mandei ele carregar. Ele caiu e falou 'ai ai, veadinho tá me matando', veado estava puxando a cabeça dele [risos]". Depois de lembrar de diversos episódios Takiri conclui, "Ele me gosta, Renato", e continua: "Mas hoje

\footnotetext{
${ }^{109}$ A agieté é uma casa toda em palha (folha do broto da palmeira babaçu) e de mesma arquitetura da casa grande, tavyve, ou seja, planta retangular e forma abobadada, mas bem menor que a casa comunal.
} 
ele não tá nem aí, nem pensa mais [...] ele veio no Avasikirera ${ }^{110}$ a última vez. Depois não vi mais".

\section{O giro das fotografias}

0 trabalho fotográfico de Delarole entre os Asuriní sempre esteve associado ao trabalho artístico, indigenista e de pesquisa da antropóloga Regina Müller. Dessa forma, suas fotografias circularam principalmente em relatórios e materiais de difusão de ações indigenistas, publicações acadêmicas e exposições sobre a arte indígena. Sem pretender realizar um levantamento exaustivo acerca dos locais onde as fotografias de Delarole circularam, cito, nesta seção, alguns exemplos para que o leitor tenha a dimensão da importância deste acervo para a divulgação e construção da imagem dos Asuriní do Xingu em diversos espaços.

Nas décadas de 1970 e início dos anos 1980, as fotografias de Delarole foram usadas na divulgação e na denúncia de problemas que afetavam a vida dos Asuriní (ver prancha 1). Em edição de 1977 a revista Veja trouxe uma curta entrevista com a antropóloga Regina Müller em que ela denuncia a atuação da Funai, que proibiu a realização de rituais xamanísticos para cura do crescente número de enfermos. Outra crítica à atuação do órgão indigenista oficial foca no trabalho de comercialização de peças de cerâmica realizado pelo chefe de posto da aldeia, que atribuiu valores arbitrários às peças sem o menor diálogo com os índios.

A edição de 1979 da Revista de Atualidade Indígena traz uma longa matéria sobre a vida ritual dos índios do Koatinemo, de título "Assurini: intimidade com o sobrenatural". É novamente Müller quem fornece as informações e enfatiza a importância da cura xamânica nos processos de recuperação demográfica, inclusive no tratamento de doenças adquiridas no póscontato, tais como febre e gripe. Em outubro de 1980, foi a Revista Geográfica Universal que dedicou uma parte importante da edição aos índios. A matéria "Os

\footnotetext{
110 Aldeia em que os Asuriní residiram depois de se mudarem do Koatinemo Velho, nas margens do Ipiaçava, e antes de se instalarem no atual Koatinemo, nas margens do rio Xingu.
} 
últimos índios tupi da Amazônia" intercala o texto escrito por Müller com as fotografias de Delarole. Com exceção da matéria da revista Veja, que utiliza apenas duas fotografias, as demais abusam das imagens do fotógrafo e a colocam em destaque, conferindo a elas parte da responsabilidade de contar como são os índios, além de sensibilizar o leitor à realidade do povo recém-contatado pela exposição de imagens de rituais e a exuberância dos motivos gráficos.

Em 1983, com Lux Vidal, Müller fez a curadoria da exposição "Abstração geométrica na pintura indígena", que reuniu cerâmicas e outros objetos da cultura material asuriní juntamente com algumas fotografias de Delarole que abordam, basicamente, a arte gráfica e o ritual (imagem 1). Objetos e fotografias foram expostos no Museu de Arte Contemporânea MAC-USP; a abertura ocorreu em abril de 1983. Em 2000, as fotografias de Delarole são exibidas na Mostra do Redescobrimento, a megaexposição comemorativa dos 500 anos do Brasil, realizada pela Fundação Bienal de São Paulo, em companhia de algumas peças do repertório asuriní, notadamente panelas de cerâmica e objetos rituais. Depois da experiência de curadoria na Mostra do Redescobrimento foi a vez do trabalho junto à exposição "Brèsil indien: les arts des Amérindiens du Brèsil", em 2005 (imagem 2). Nesta ocasião, as fotografias viajam à cidade das luzes, Paris, para integrar a exposição que permaneceu três meses no Grand Palais.

Na exposição itinerante "Ritual da Imagem: Arte Asuriní do Xingu", fotografias de Delarole novamente foram utilizadas para apresentar ao público o espaço da imagem, da arte gráfica e do ritual entre os Asuriní. Além disso, algumas fotografias foram comercializadas como cartões postais, e a venda, revertida para a Associação Indígena Asuriní Awaeté. A exposição percorreu diversas cidades, ficando em cartaz no Museu do Índio do Rio de Janeiro - RJ em 2008, Museu da Inconfidência em Ouro Preto - MG em 2011, Museu de Artes e Ofícios - MAO/ Instituto Cultural Flávio Gutierrez em Belo Horizonte - MG em 2009.

Dentre os trabalhos de divulgação científica é fundamental mencionar a presença das fotografias de Delarole na publicação-marco "Grafismo Indígena", organizada por Lux Vidal em 1992, que em treze artigos mostra a imensa riqueza da arte gráfica entre os índios do Brasil. No artigo escrito por Müller , "Tayngava, 
a noção de representação na arte gráfica Asuriní do Xingu", há três retratos de Delarole ressaltando a pintura corporal asuriní. Outros textos acadêmicos trazem imagens de Delarole ${ }^{111}$; no entanto, na maioria dessas publicações, as fotografias não ganham tanto destaque, sendo impressas sem grande qualidade.

Em contraposição à apresentação das fotografias na maior parte das publicações acadêmicas, as imagens ganham notoriedade nos catálogos de exposição em que são reproduzidas em tamanho ampliado (página inteira), em impressões de qualidade e conforme uma concepção gráfica em que são realçadas na relação com os textos. Para citar um exemplo, o catálogo da exposição Brèsil Indien, Les arts des Amérindiens du Brésil, de 2005, contém diversas fotografias de pintura corporal e ritual asuriní.

111 Para citar dois exemplos, o artigo "As crianças no processo de recuperação demográfica dos Asuriní do Xingu", publicado na coletânea Crianças Indígenas - ensaios antropológicos, organizada por Aracy Lopes da Silva, Ana Vera Lopes da Silva e Angela Nunes. São Paulo, Global, 2002; e o artigo "Danças indígenas: arte e cultura, história e performance", publicado na coletânea Dança da Terra, organizada por Zeca Ligiéro e Claudio Alberto dos Santos. Rio de Janeiro: Papel Virtual Editora, 2005. Nos dois casos, as fotografias são impressas sem grande qualidade (PB e em tamanho pequeno, menos de um quarto de página) e são apresentadas com a função primeira de ilustrar as informações presentes no texto. 


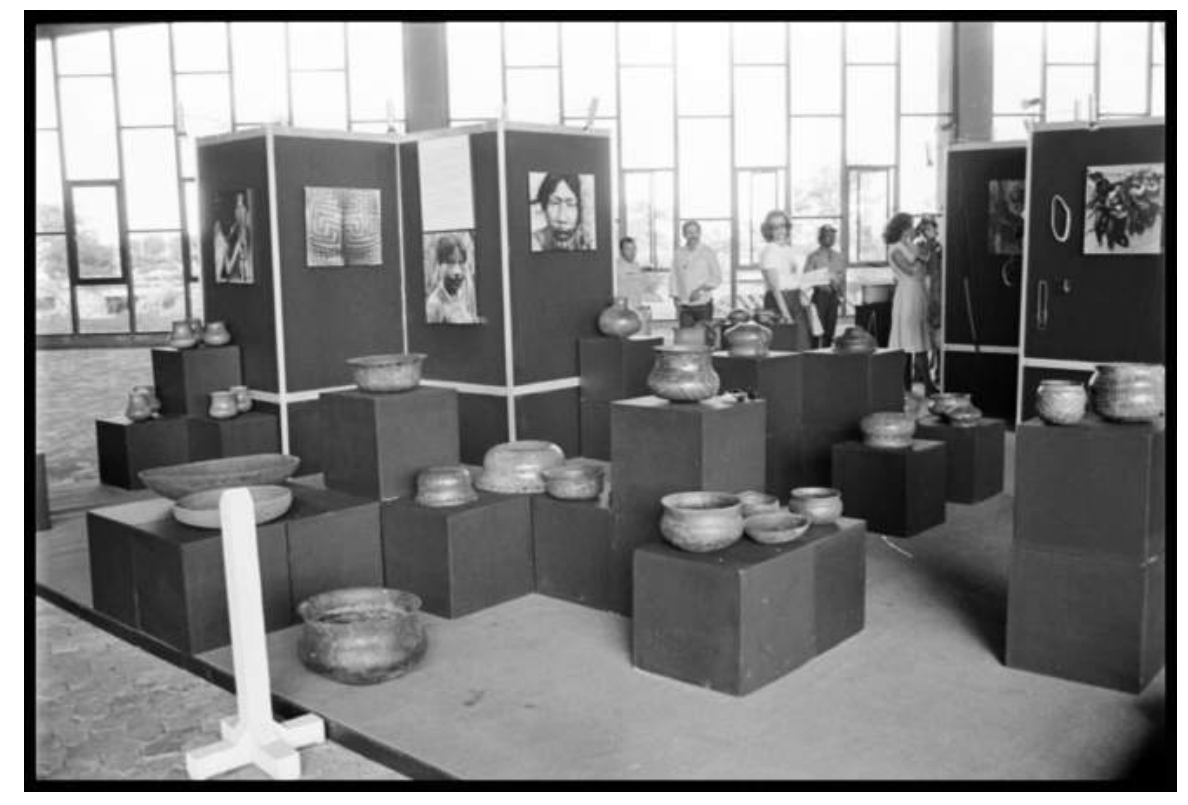

Imagem 1

Exposição "Abstração geométrica na pintura indígena", MAC-USP. Foto: Renato Delarole, 1983.

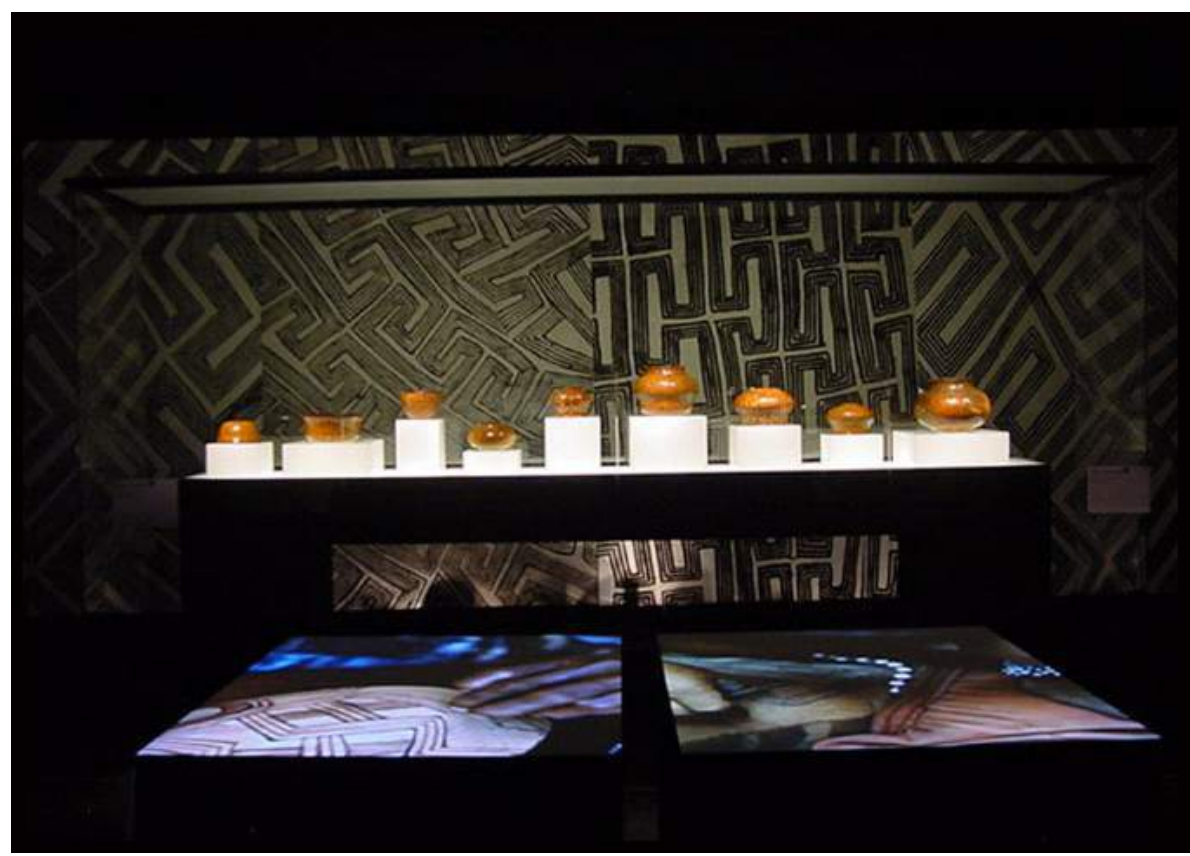

Imagem 2

Exposição "Brèsil indien: les arts des Amérindiens du Brèsil", Grand Palais, Paris, 2005. 
prancha 1

\section{Publicacão das fotografias de Delarole em revistas}
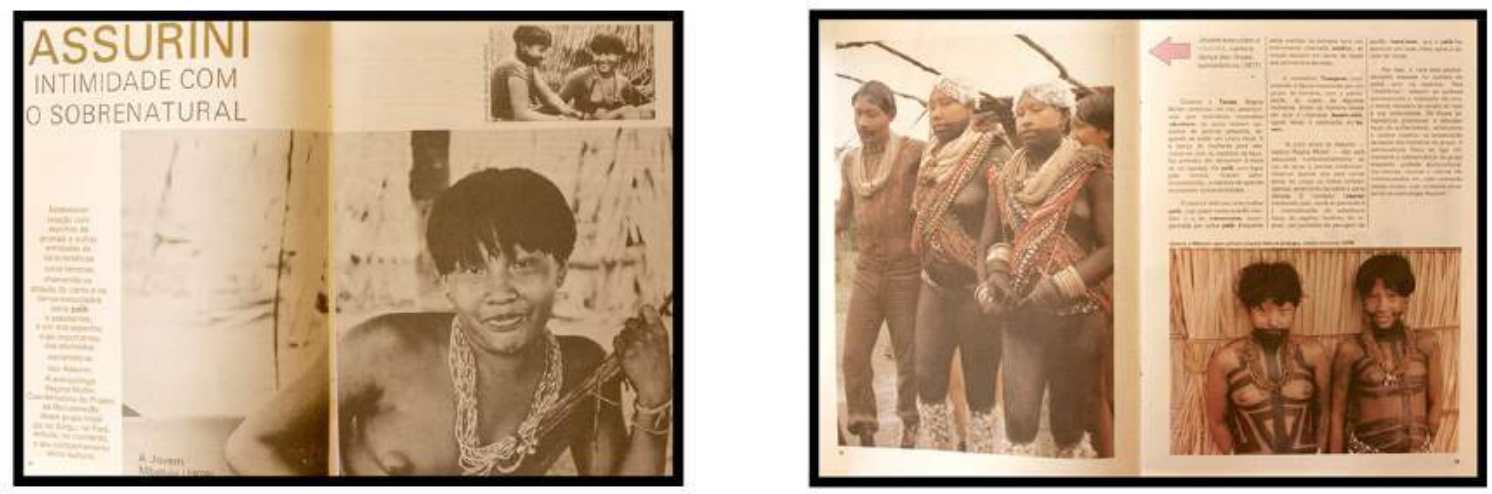

Imagens acima: matéria da Revista de Atualidade Indígena, 1979.

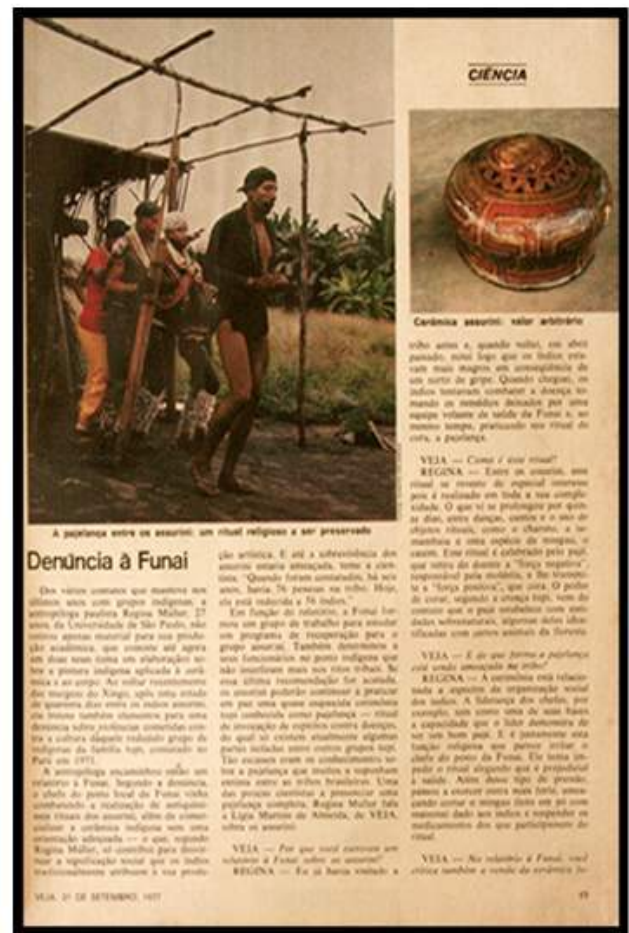

Imagens acima: matéria "Denúncia à Funai", Revista Veja, 1977.

Imagens abaixo: matéria da Revista Geográfica Universal, 1980.
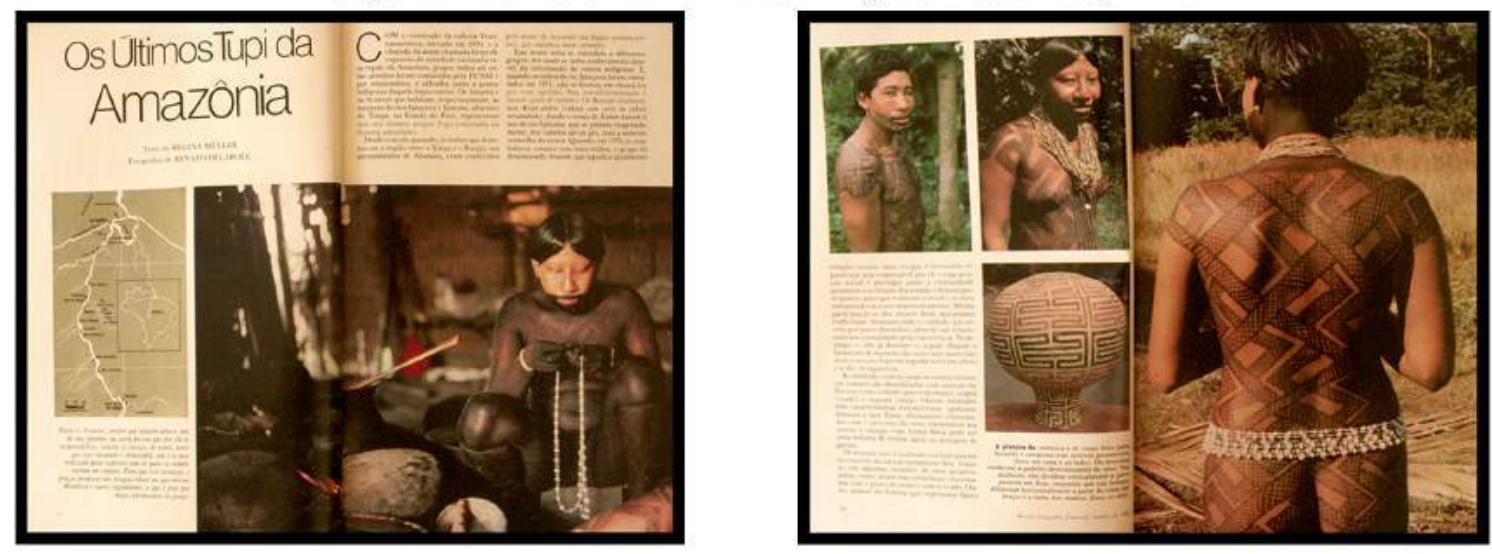


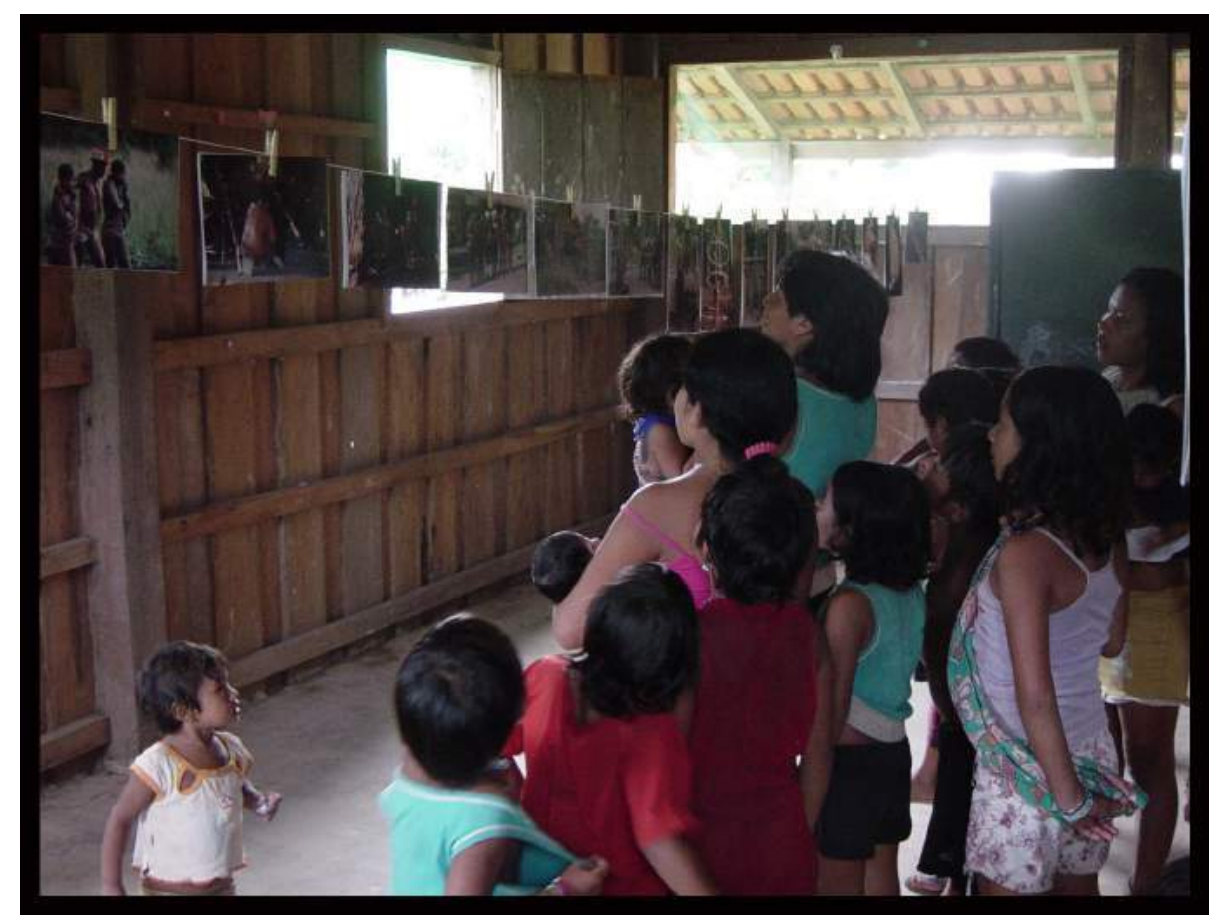

Imagem 3

Asurinís olham com atenção as fotografias de Delarole em exposição.

Foto: Alice Villela, 2006.

Em pelo menos duas ocasiões o acervo fotográfico de Delarole retornou para a aldeia de forma sistemática. Na primeira, em 2006, quando o já citado projeto "Documentação e Transmissão dos Saberes Tradicionais dos Asuriní do Xingu - Iphan" digitalizou o conjunto completo de imagens do fotógrafo no Koatinemo. E a segunda, na oportunidade desta pesquisa de doutorado, quando circulei de casa em casa as fotografias. Em 2006, a forma mais efetiva de acesso às imagens foi via exposição de parte delas na Escola Indígena Kwatinemu (imagem acima). Penduradas em singelos varais armados nas salas de aula, as imagens - ampliações em papel fotográfico de $20 \mathrm{~cm}$ por $30 \mathrm{~cm}$ - ficaram expostas e, durante alguns dias, receberam a visita de todos. Eu estava na aldeia nesta ocasião mas não me lembro de significativos comentários asuriní ou discussões a partir da exposição. Interessava-nos, naquele momento, mais a devolução do material de pesquisa de Müller aos índios do que um trabalho estendido e aprofundado com as imagens. 
Diferentemente do contexto institucional da exposição realizada em 2006 na escola indígena, em trabalho de campo optei por circular as imagens no âmbito privado das casas e de tal forma que os Asuriní pudessem olhar, contemplar e manusear as fotografias impressas pelo tempo que fosse necessário. As próximas páginas são dedicadas aos efeitos, memórias, lembranças e reflexões suscitadas pela circulação das fotografias de Delarole entre os Asuriní de hoje.

\subsection{Notas sobre a recepção asuriní}

As pouco mais de 750 imagens produzidas por Renato Delarole entre 1977 e 1986 difundiram-se de casa em casa nas aldeias Ita'aka e Koatinemo durante os meses de maio e junho de 2015. De crianças a velhos, todos queriam ver os "antigos". As fotografias eram chamadas geralmente de bavarayngava, em que bava = Asuriní que já morreram ou "antigos" na tradução para o português, e ayngava = imitação, imagem, mesmo termo aplicado às fotos de Lukesch, abordadas no capítulo anterior. No entanto, os Asuriní faziam uma diferenciação entre as fotografias dos padres e as de Renato, enfatizando que nas do contato estavam retratados os bava eté - em que eté é intensificador, "de verdade" indicando que se tratavam dos "antigos" mais recuados no tempo.

A presença massiva de pessoas falecidas nas fotografias, ao contrário do que poderíamos supor, não causou incômodo algum, diziam sempre que aquelas pessoas "morreram faz tempo". Em relação à enunciação do nome dos falecidos, observou-se que, ao comentar sobre as pessoas retratadas nas imagens entre eles, não pronunciavam os nomes próprios dos falecidos, servindo-se sempre dos termos de parentesco tendo a si mesmos ou a terceiros como referência ${ }^{112}$. No entanto, não ofereciam resistência em mencionar os nomes quando questionados por mim ou pelas crianças e jovens Asuriní. No caso de o nome já pertencer a alguma pessoa viva, diziam o nome do morto sem qualquer impedimento e sem que eu ou algum Asuriní solicitássemos; neste caso, insistiam em explicar o grau de parentesco entre a pessoa viva e o morto. Uma experiência que serve como

112 Ver termos de parentesco em anexo. 
exemplo foi o caso da fotografia de Avona. Veveí separou uma das inúmeras fotografias em que o índio é retratado dizendo que queria dar ao seu neto, Itareí, pois ele deveria conhecer o avô do qual herdara o nome. Um dos nomes de Avona é Itareí e é dele que o neto de Veveí herdou o nome pois o velho retratado é pai de sua mãe, Apyrakamy.

Fotografias despertaram memórias dos parentes, saudades de entes queridos, lembrança de situações marcantes e geraram comentários e reflexões a respeito de como era a vida dos Asuriní no Koatinemo Velho e como é a vida dos Asuriní de hoje. Os velhos não ficaram satisfeitos em ver as fotografias apenas uma vez, queriam apreciá-las e manuseá-las repetidamente, de modo que o movimento de ver e lembrar dos parentes retratados era reforçado. A cada novo encontro com as mesmas imagens, outras histórias surgiam. Os mais novos viram muitos de seus parentes pela primeira vez e, cheios de curiosidade, remetiam-se aos velhos requisitando explicações.

Embora as sessões de apreciação, manuseio e exame das fotografias tenham sido realizadas nos núcleos residenciais, ou seja, no meio de crianças, adultos e velhos, seus efeitos e repercussões podem ser agrupados de acordo com diferentes faixas de idade ${ }^{113}$. Nota-se a distância entre o que as fotografias suscitaram entre os muruviava, velhos de mais de 60 anos, entre as mulheres na faixa dos 40 e 50 anos e entre os "novos", especialmente pessoas da faixa entre 20 e 30 anos, adultos maduros. De modo sumário, a força das fotografias em reavivar memórias, motivar relatos e gerar reflexões análogas entre pessoas dentro das diferentes faixas de idade está relacionada ao fato de elas terem vivido experiências equivalentes no período em que Delarole fotografou, ou simplesmente não as terem vivido, como no caso das crianças e de alguns adultos que não tinham nascido na época. Dentre a fração dos mais novos que

113 Segundo classificação esboçada por Miranda a partir de informações fornecidas pelo jovem professor Koatireí, emprega-se a palavra kunumi para se referir a alguém que tenha até mais ou menos 13 anos. Desta idade até cerca de 22 anos as moças podem ser chamadas de kunatajã e os moços avavuja; os adultos entre 23 e 60 anos seriam considerados upyta e os velhos acima de 60, muruviava. Essas categorias teriam conexão com a maturidade da pessoa e poderiam ser medidas por meio do endurecimento/amolecimento dos ossos. Por exemplo, um kunumi teria os ossos amolecidos e a passagem para a categoria de kunatajã ou avavuja teria como condição o endurecimento dos ossos. Os velhos já começam a ficar com os ossos moles novamente (Miranda, 2014, p. 64-65). 
demonstraram interesse pelas imagens, especialmente os professores das aldeias e as lideranças jovens, a motivação residiu, basicamente, na possibilidade de conhecer como eram os Asuriní no passado, o que abrange a oportunidade de ver seus parentes próximos quando mais novos, conhecer parentes falecidos, aprender o "jeito" dos antigos (aereka, "nosso jeito") e saber dos conhecimentos (kuakuava) específicos asurini, tendo sua curiosidade (akuap putat, "eu quero saber") ativada pelas imagens.

Para as mulheres que têm entre 40 e 50 anos, a circulação das fotografias gerou uma série de reflexões e comentários comparativos entre o modo de vida que têm hoje e como viviam no passado. Para elas, não foram os "antigos", parentes falecidos, que mais chamaram atenção, e sim a possibilidade de ver a si mesmas quando novas.

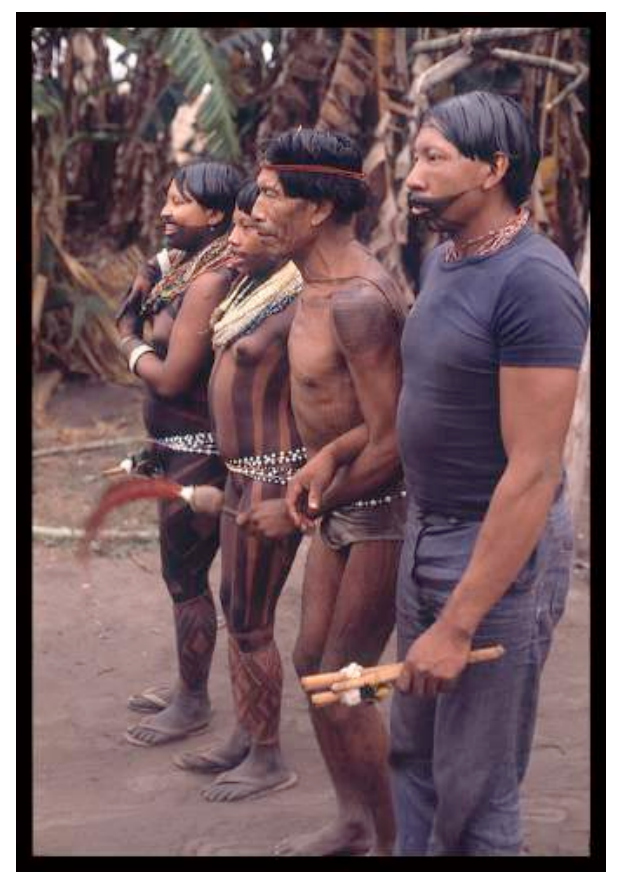

Imagem 4

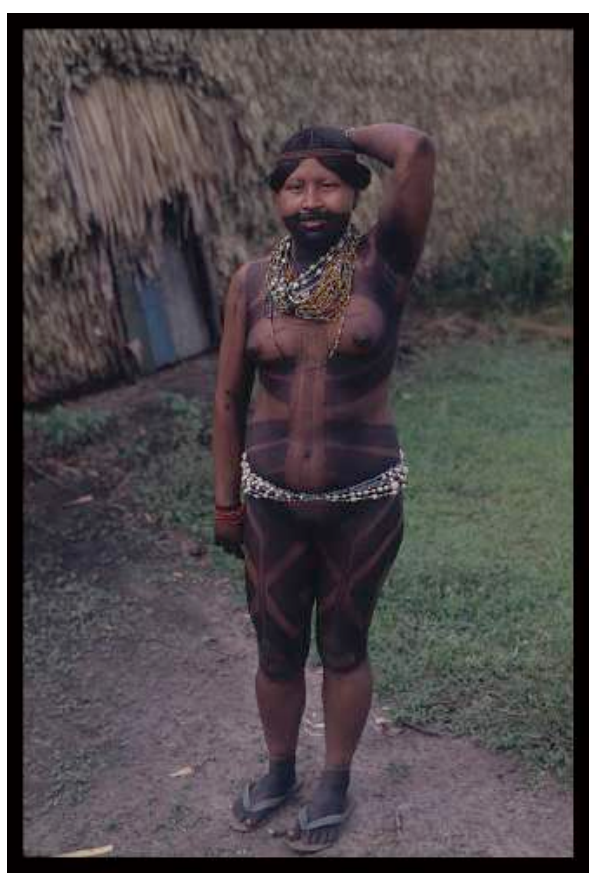

Imagem 5

Imagem 4. Mará dança em ritual xamanístico com seu marido e pajé Pinasiré. Da esquerda para a direita: Mará, Matuia, Pinasiré e Takamuin. Foto: Renato Delarole.

Imagem 5. Mará nova. Comentários como o de Boaiva, "Mará era bonita demais nova", foram muito freqüentes. Foto: Renato Delarole. 
Para as mulheres Apeuna, Mará, Matuia, Myrá e Murukaí, que têm atualmente entre 45 e 50 anos, foi marcante a possibilidade de verem a si mesmas no tempo em que eram jovens e bonitas ${ }^{114}$. Estas mulheres, na época moças, aparecem em muitas fotografias de meados da década de 1970 dançando ao lado dos pajés mais velhos na função de uirasimé nos rituais xamanísticos ou vanapy e muravy, dançarinas nos rituais do Tauva (ver prancha 3), funções que eram privilegiadamente executadas por meninas solteiras que já haviam se tornado moças (consideradas maduras para contrair casamento). É significativo que Matuia e Myrá pediram que eu deixasse com elas justamente as fotografias em que são retratadas dançando na festa ou apenas pintadas e enfeitadas ${ }^{115}$. Na prancha 4 reproduzo as imagens recebidas por elas: Myrá ficou com as fotografias 1, 2, 3 e 4 e Matuia, com as fotografias 5, 6, e 7 .

Após pedir de presente a imagem reproduzida acima (imagem 4), em que aparece dançando ao lado de seu primeiro marido, Pinasiré, um importante pajé já falecido, Mará comentou: "O pai de Pamevyra [seu filho mais velho de 28 anos] não queria ter filho; ele falou que era pra eu ficar enfeitada, na festa. Antigamente Asuriní era assim; ficava na festa e não tinha filho. Depois que tinha filho acabou. Agora não". Inevitavelmente as comparações entre como aconteciam as festas no período em que Delarole fotografou e como ocorrem hoje vieram à tona. Mará explicou que hoje as meninas têm filhos muito novas, a partir dos 13 anos, e a média do número de filhos também aumentou bastante comparativamente ao período em que ela era jovem. As mudanças na vida das mulheres Asuriní, especialmente em relação à idade para o início da maternidade e o número de filhos, foram suficientemente exploradas pela literatura (Müller, 2002; Miranda,

${ }^{114}$ A recepção das imagens entre os homens desta mesma faixa de idade, Apebu, Murumanaka, Takiri, Manduka, para citar alguns deles, oscilou entre a satisfação de ver os parentes falecidos e uma certa nostalgia pela vida asuriní no passado. Como as mulheres, eles também são retratados pintados e enfeitados na festa, atuando em funções de auxiliar do pajé (vanapy), além de tocador de flauta ou até kauirao (jovem investido de posição de "iniciado" no ritual Turé), mas essa experiência não apareceu em relevo no contato com as imagens. Em virtude da falta de disponibilidade desses homens para o trabalho (à exceção de Apebu), não conto com informações sistemáticas acerca das suas reações.

115 Deixei com os Asuriní todas as 750 fotografias impressas. Ao longo do período de campo fui distribuindo para aqueles que me pediam e, ao final, doei metade das restantes para escola da aldeia Koatinemo e a outra metade para a escola da aldeia Ita'aka. 
2014, dentre outros), motivo pelo qual não me alongo neste ponto. Apenas para reiterar algumas observações - que nos permitem compreender os comentários de Mará sobre as fotografias -, na década de 1970, Müller registrou que a idade ideal para a procriação entre as mulheres variava entre 20 e 25 anos; até esta idade, elas dedicavam grande parte de seu tempo às atividades rituais e à arte gráfica. Em 1976, momento em que o trauma do contato se fazia sentir, Müller registrou a existência de 26 mulheres adultas, das quais apenas dez geravam filhos, e, das sete com mais de 45 anos, apenas uma. Realidade muito diferente do que ocorre atualmente, quando, a partir dos 13 anos, as meninas já estão casando e tendo o primeiro filho; não raro, há moças na faixa dos 20 anos com mais de 4 filhos ${ }^{116}$.

Marakauá, índia velha, também enfatizou a participação das mulheres nas festas antigamente ao lembrar que, quando Parakakyja foi dançar pela primeira vez na festa, há cerca de vinte anos, Matuia (nora de Parakakyja) falou para ela: "Eu, quando era nova, dançava sem calcinha, só com pintura e colar". Sobre a fotografia reproduzida a seguir (imagem 6), ela comentou: "Eu só fico nova no Koatinemo Velho, sem roupa, pintada, toda a vida dançava. Aqui [aldeia atual] não faz mais nada".

\footnotetext{
116 Como é o caso de Murapyjava, de 23 anos, que tem 6 filhos, a mais velha com 10 anos; de Jejy'i, de 24 anos, com 5 filhos; Kumé, de 26 anos, com 4 filhos; Kyraí e Karakatu, ambas com 26 anos e com 5 filhos. Entre as mulheres de 30 e 40 anos a tendência é o número de filhos aumentar: Tevutinemi com 31 anos e 7 filhos, Parakakyja com 32 anos e 6 filhos e Taymira com 37 anos e 11 filhos.
} 


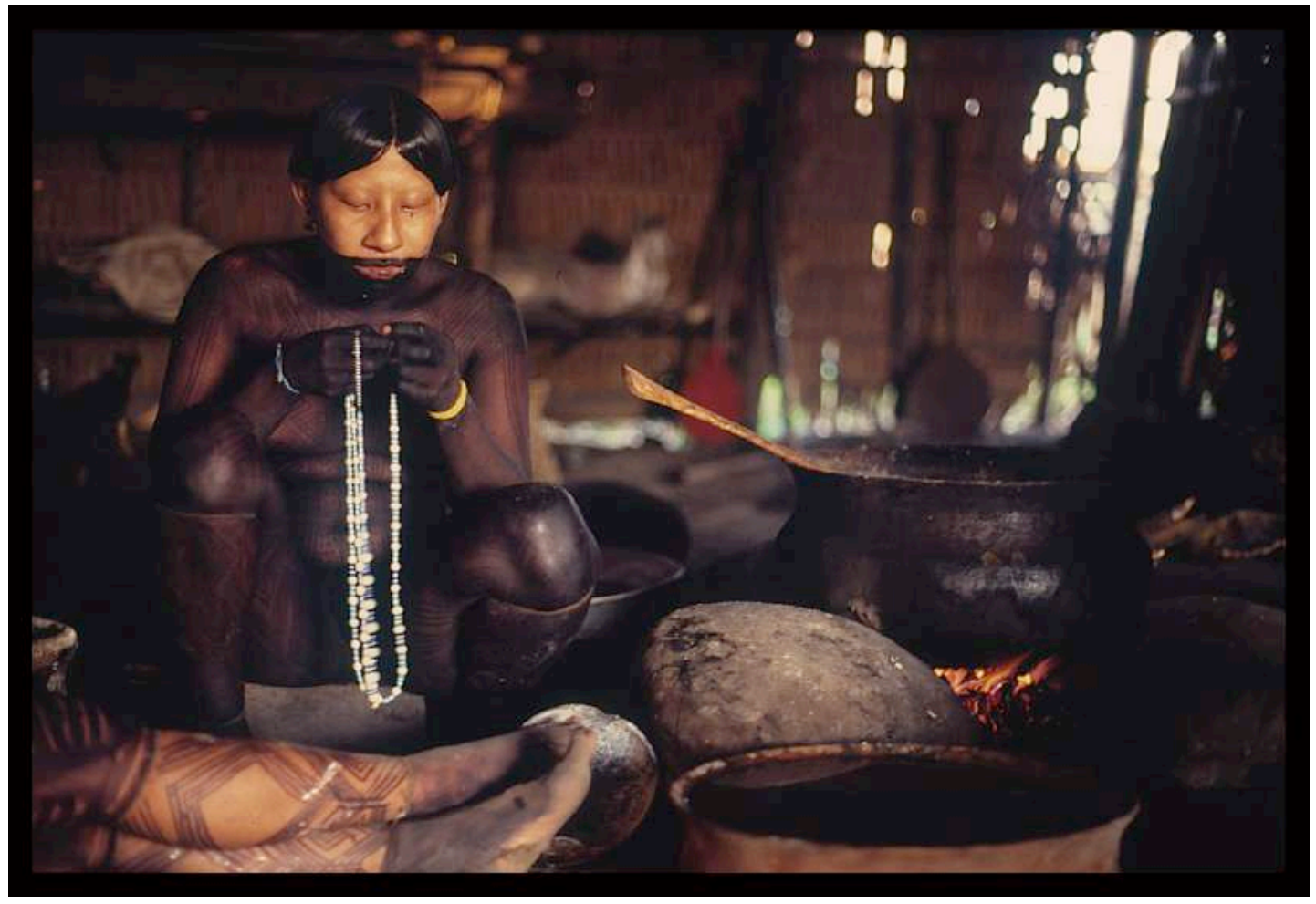

Imagem 6

Marakauá pintada fazendo mingau para a festa do maraká na posição de uirasimé. Foto: Renato Delarole.

Mulheres como Mará, Matuia e Myrá, ao verem as fotografias de Delarole, procuraram ver a si próprias quando moças, novas e bonitas (ikatuip). Admiraram-se com suas próprias figuras no apogeu de sua mocidade, entusiasmaram-se ao se verem dançando pintadas como uirasimé, ponto alto das imagens. Pegaram algumas fotos com a promessa de que fariam quadros para pendurar na parede de suas casas ou para mostrar para os filhos. Para elas, as imagens funcionaram como um espelho generoso, que subtrai o tempo. 
prancha 2

\section{Sessões de fotografias nas aldeias Ita'aka e Koatinemo Maio e junho de 2015}
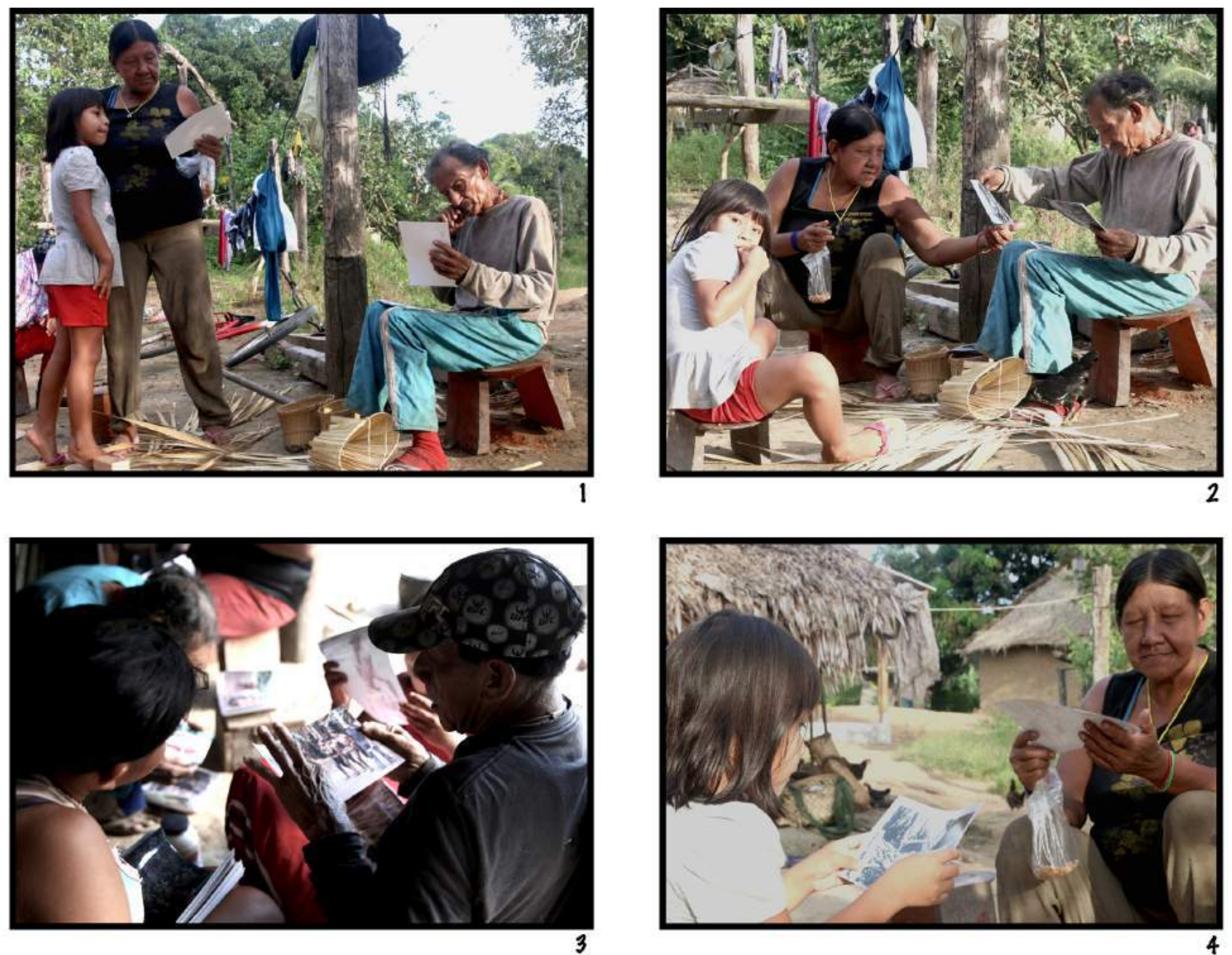

Fotos: Alice Villela

Neste conjunto de imagens as fotografias circulam no pátio em frente à residência de Koati (aldeia Koatinemol, velho sentado nas fotos 1 e 2 acima. Murukai, sua esposa (fotos 1,2 e 4), também se interessa e Boaiva (foto 3), que frequenta a casa de Koati pois tem um filho casado com uma filha dele, também participa das sessões. A menina que aparece nas imagens é filha de Boaiva. 

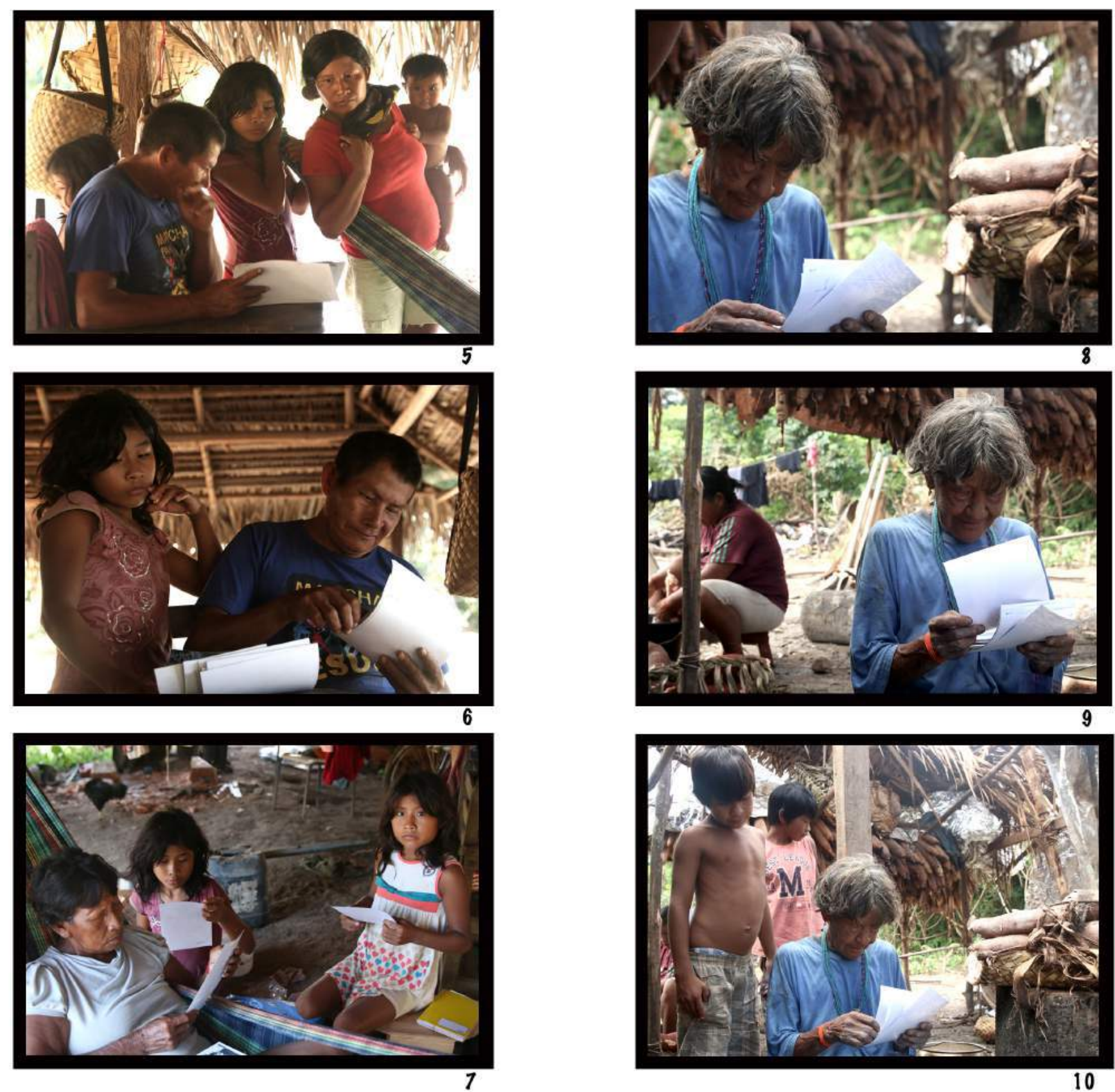

Fotos: Alice Villela

Na sequência das imagens 5,6 e 7 as fotos säo mostradas no núcleo de Apewu (aldeia Koatinemo). Na foto 5 também está presente Karakatu, sua nora com os filhos e na foto 7 sua esposa, Weweí, examina as fotografias ao lado das netas. Nas fotos 8,9 e 10 Ajuruí (aldeia Ita'aka) vê as imagens, na última da sequência um menino, filho de Takamy, seu marido, também as observa. 


\section{pracha 3}

\section{Jovens dancam no ritual do Tauva}
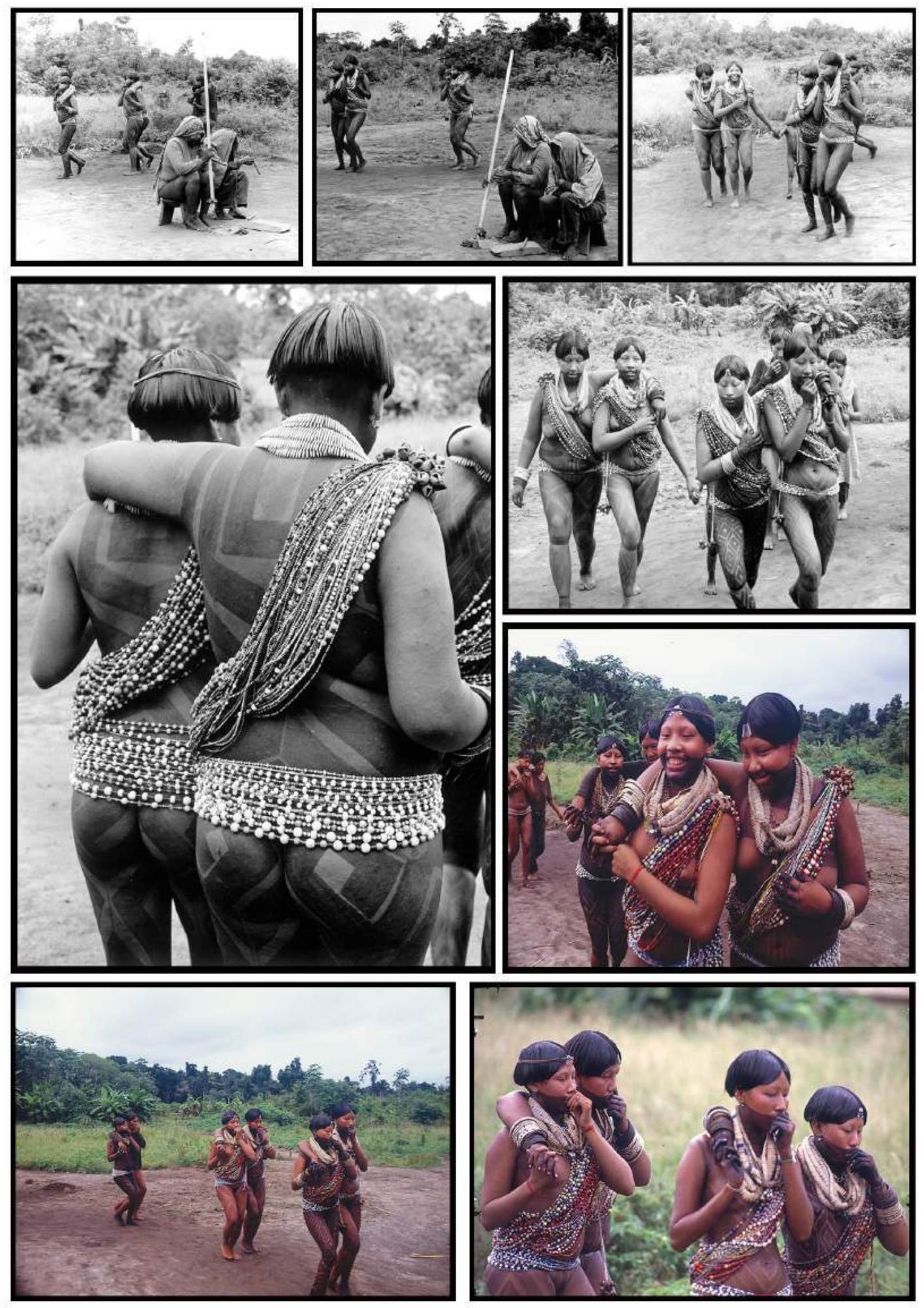

Fotos: Renato Delarole, 1978 e 1980.

Nas fotos acima, as duas tauyva cantam sentadas com 0 chocalho ava'ip. As mosas no papel de vanapy e muravy dangam abraçadas em duplas: Matuja e Murukai, Apeuna e Myrá. Elas levam as mäos à boca para responder ao canto da tauyva. Chama a atensäo a quantidade de enfeites usados: kajyja (colar de dente de macaco), muyjovaia (colar cruzado de micangal, mypijara (jauará pendurado no colar), ka'apuava (colar de cintura), maritá (pulseiral só de côco ou com mytukyga (osso de mutuml, atyva (enfeite de cabeşa feito de prato de cerâmica), tapukura (enfeite de perna feito de linha de algodão), tupaii I linha na cabecal, namikwayma (brincol além das pinturas (juaka). 
prancha 4

\section{Fotos que Myrá e Matuja} escolheram como recordação

Fotos 1,2,e 3 Myrá e Apeuna.

Foto 4 "Eu nova" (Myrá).
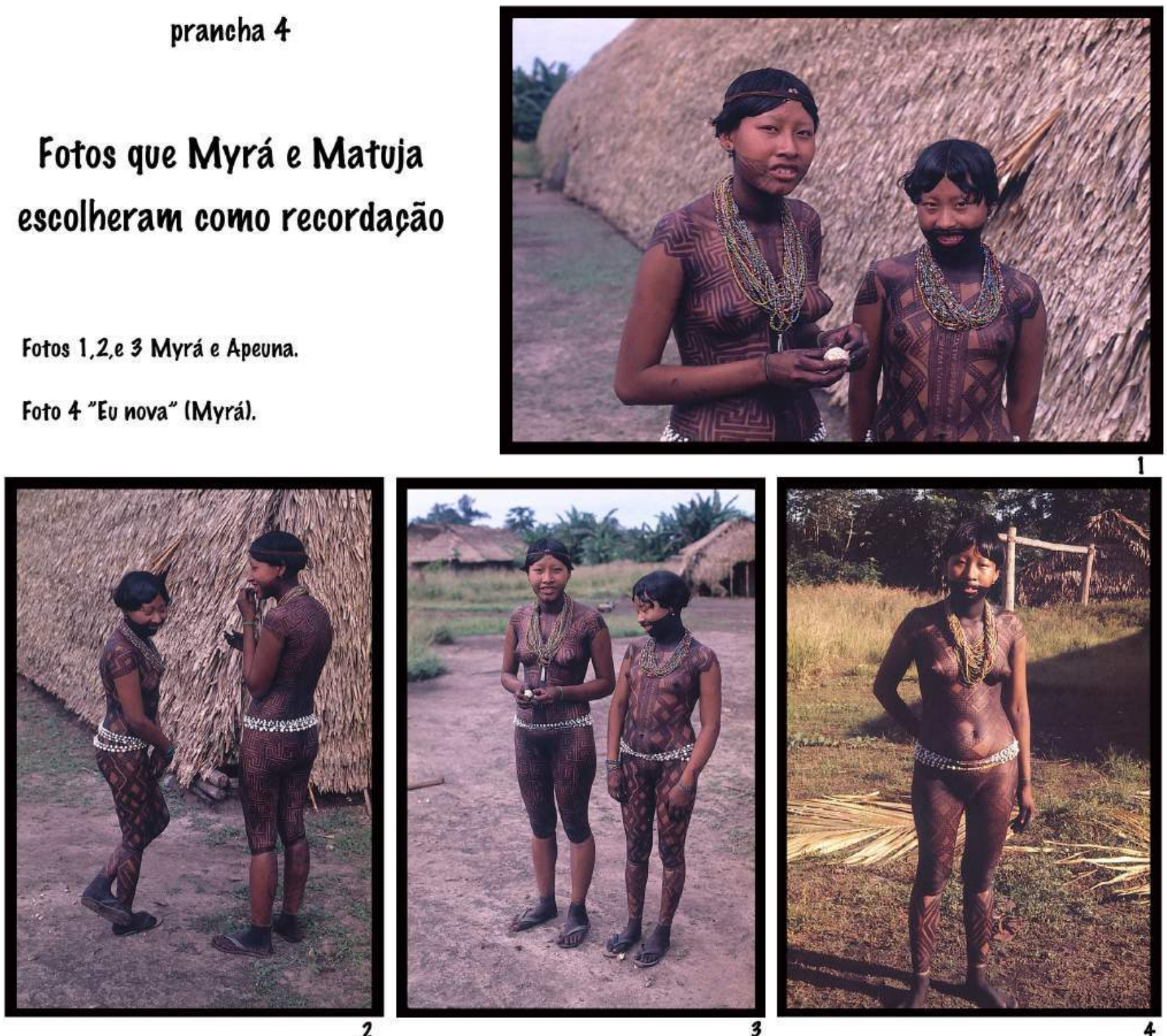

Fotos 5,6 e 7 Matuja nova. "Eu bonita, pintada" (Matuja).
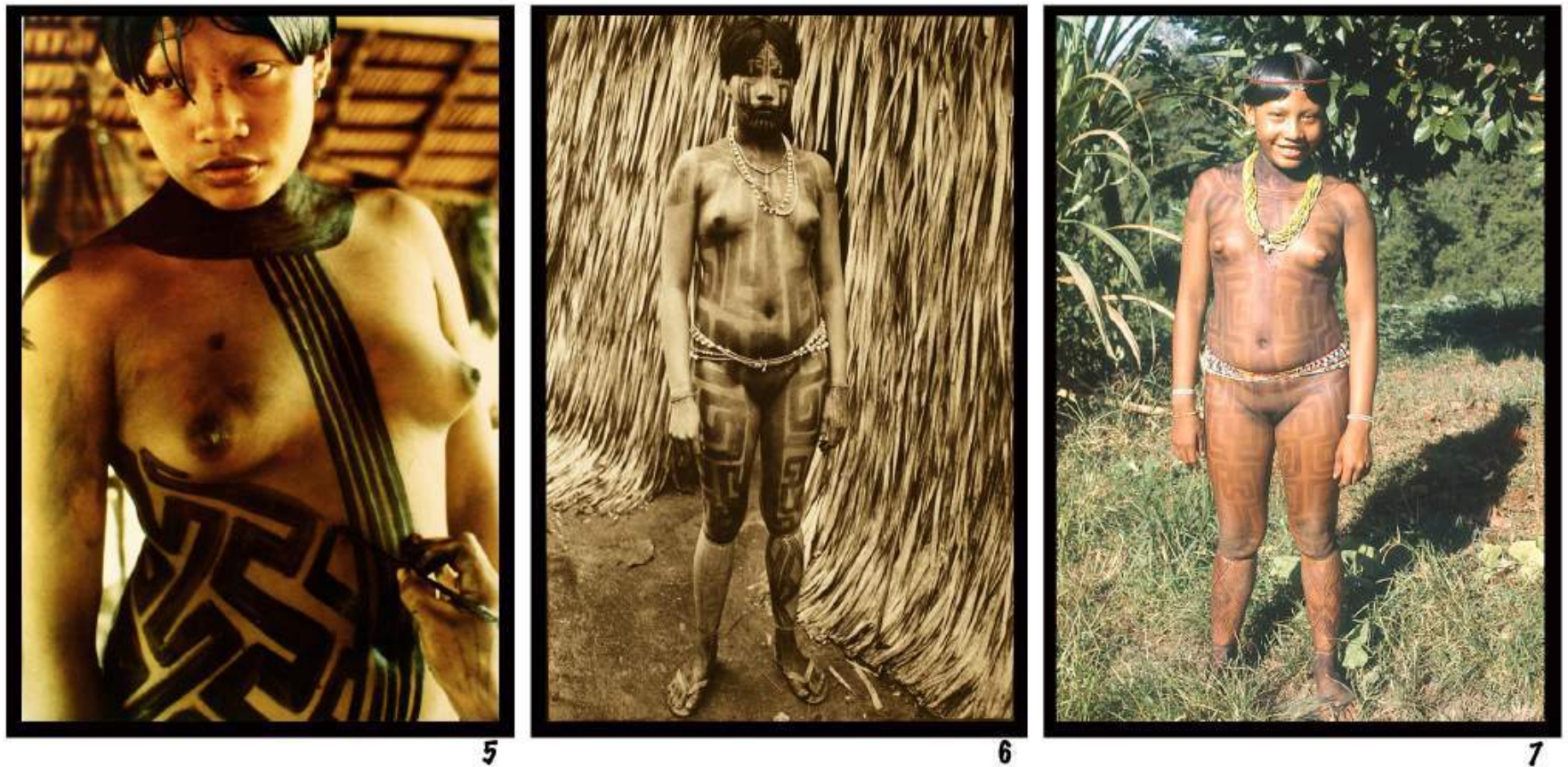

Fotos: Renato Delarole 


\subsection{Ver e lembrar, a memória dos parentes ${ }^{117}$}

"Antigo é assim. É bom ver quem era vivo". (Apebu, ao ver fotografias de Delarole)

Para os Asuriní que eram adultos durante a permanência de Renato Delarole nas antigas aldeias ${ }^{118}$, as fotografias ativaram memórias de relações, vínculos de pertencimento, elos, eventos e histórias ocorridas nas imediações das relações próximas com os "antigos" Asuriní.

Quem primeiro indicou o elo entre parentes via fotografia foi o ancião Mure'yra. O velho foi o primeiro a ver e a manusear as fotografias que levei ao campo. Sua curiosidade em saber o que eu havia trazido para eles "desta vez" o impeliu a vir ao meu encontro nas acomodações da farmácia logo de manhã, após a primeira noite na aldeia Koatinemo. Do primeiro bloco de fotografias, cerca de 60 imagens impressas foram vistas uma a uma. 0 olho percorria toda a foto; por vezes se dava conta de que o sentido da imagem não era aquele que ele olhava, então ele mesmo girava, reposicionando-a. Eu apenas observava. Não dizia nada, esperando alguma reação, manifestação, expressão. Cada imagem era examinada com cautela pelo índio. Deixei que ele pudesse se relacionar com as imagens. Lentamente começou a me dizer: "jeky'yra", "jerendyra", "jesemere", apontando para as pessoas retratadas nas imagens. Ao perceber que eu não compreendia exatamente, arriscava uma tradução para o português: "irmão", "mamãe Matuia", "Takiri papai", etc. O esforço de Mure'yra foi dispendido, todo o tempo, a tentar reconhecer quem estava presente no retrato.

\footnotetext{
117 Falo em parente aqui da maneira como os Asuriní o empregam, como uma tradução do termo retá (jeretá, meu parente). Futuramente pretendo aprofundar como são considerados os parentes ou quem são, da perspectiva asuriní, os parentes, o que certamente poderá render boas reflexões sobre a relação dos índios com as fotografias. 118 Ou seja, pessoas que em 1976, data em que Delarole chega no Koatinemo Velho pela primeira vez, tinham pelo menos 20 anos, como é o caso de Boaiva, Mure'yra, Koati, Takamuin, Moteri, Ajuruí, Burí, Aramé. A maior parte das imagens foi registrada na aldeia Koatinemo Velho, lugar de que os Asuriní lembram bem. No Avasikirera, Delarole fotografou durante o curto período em que permaneceu entre os índios em 1986.
} 
Tanto Mure'yra quanto Marakauá foram muito além do reconhecimento dos parentes. Ambos olharam as 750 fotografias detidamente em função do forte interesse que, logo de início, demonstraram, o que foi exequível graças ao tempo que dispuseram para o trabalho. Com eles foi possível nos debruçarmos sobre as fotografias e, assim, ouvir diversas histórias e conhecer melhor as memórias que estavam sendo despertadas. Outro trabalho realizado consistiu no mapeamento das imagens mais significativas para cada um no contexto da totalidade do acervo. A seleção dos dois, ou "álbuns", refazem relações e vínculos de parentesco com algumas das pessoas retratadas nas imagens.

O album da Marakauá, o álbum do Mure'yra ${ }^{119}$

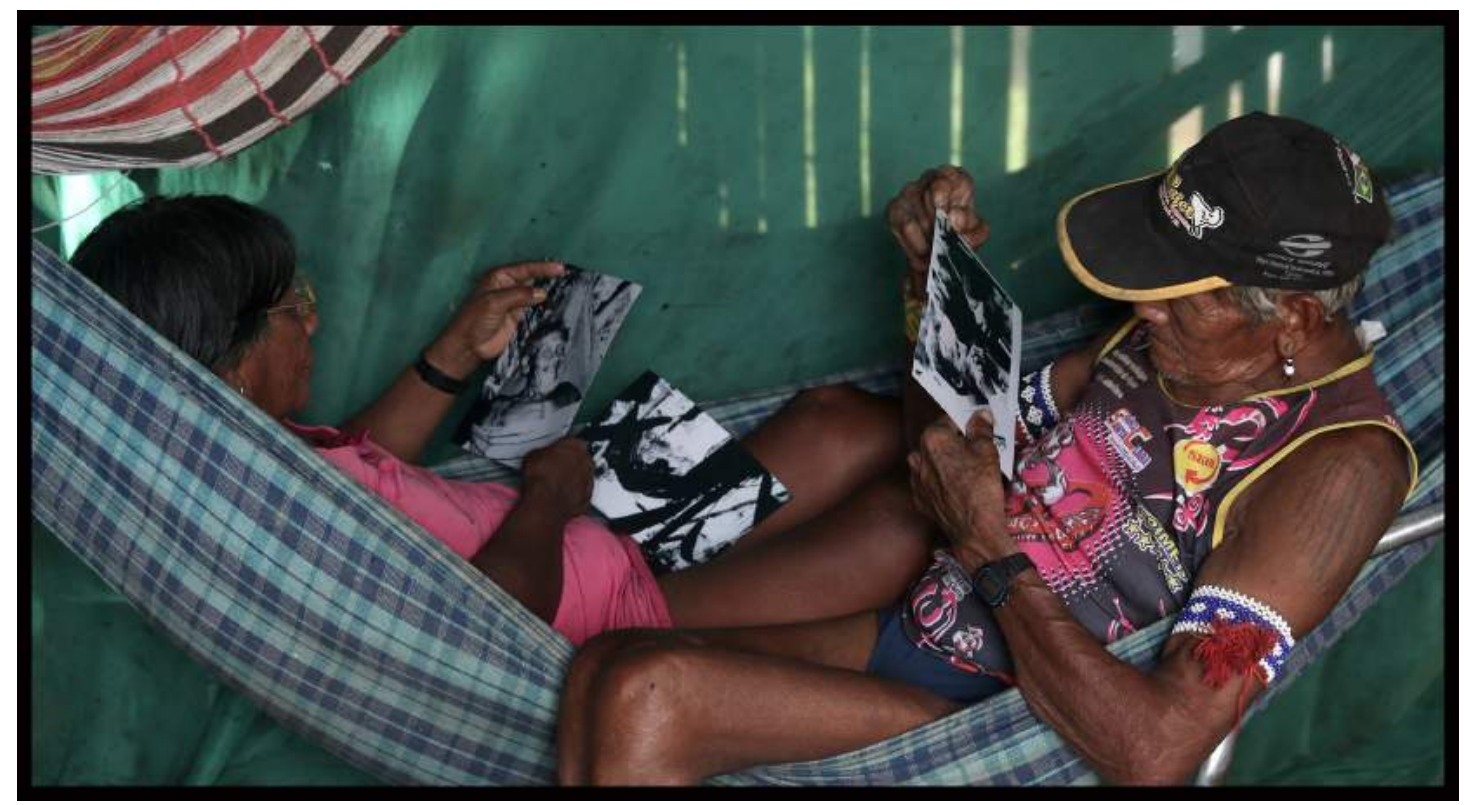

Imagem 7

Mure'yra e Marakauá durante sessão com as fotografias na residência do casal. Foto: Alice Villela, maio de 2015.

\footnotetext{
${ }^{119}$ Nesta seção, não me dedico a analisar as imagens selecionadas, apenas as exibo nas pranchas, indicando os comentários realizados, pois se trata da apresentação de um procedimento metodológico que me auxiliou a tornar clara a dinâmica das fotografias como possibilidade de lembrar dos "parentes".
} 
A fotografia reproduzida acima traz um pouco do ambiente de intimidade em que se realizaram as sessões fotográficas com o casal. Depois de mais de uma semana em encontros diários com Marakauá e Mure'yra, chegamos à seleção bem resumida das imagens mais significativas. Com Marakauá chegamos a 15 fotografias (prancha 6) e com Mure'yra, a 11 (prancha 5). Para não parecer absurdo o resultado de partir de pouco mais de 750 e chegar a menos de duas dezenas, devo explicar o procedimento de trabalho. Enquanto contemplavam e examinavam as imagens, ambos iam tecendo comentários, geralmente associados aos parentes retratados. Ao fim de cada dia de trabalho eu lhes perguntava sobre o que mais os havia marcado, quais imagens recém-vistas eram as mais significativas, e sugeria que indicassem uma ou duas dentre as mais expressivas. Embora tecessem comentários identificando praticamente todas as pessoas retratadas, quando eram solicitados a escolher algumas dentre o grande montante de imagens, sempre preferiam seus parentes próximos. É óbvio que os comentários não ficaram restritos aos parentes; por vezes, o casal também identificou o que mais as fotografias traziam como referente: objetos, ações, lugares, etc.

Ainda a respeito da proposta de seleção, ao final das sessões, sugeri que eles escolhessem dentre as pré-selecionadas no máximo cinco fotografias cada um; disse que as imagens escolhidas eu lhes ofereceria como presente. Dentre as pré-eleitas, Mure'yra escolheu três (imagens 3,4 e 9 da prancha 5) e Marakauá, apenas uma (imagem 7 da prancha 6). Com estas poucas imagens em mãos, pedi que olhassem detidamente foto por foto e que me contassem histórias. Marakauá se envolveu com a proposta e forneceu relatos interessantes; tais narrativas serão tratadas nas próximas seções; por ora, vejamos como ficaram as seleções de Mure'yra e Marakauá e o modo como se apropriaram do grande acervo de imagens para refazer laços de parentesco com as pessoas retratadas ${ }^{120}$.

\footnotetext{
120 Reproduzi as indicações e comentários da maneira como Mure'yra e Marakauá fizeram, incluindo traduções, explicações e nomes próprios quando necessário. A tradução dos termos de parentesco foi utilizada tendo como base a terminologia de relações de parentesco sistematizada por Müller (1993, p. 309-310) que está reproduzida em anexo.
} 


\section{prancha 5}

\section{Seleção Mure'yra}

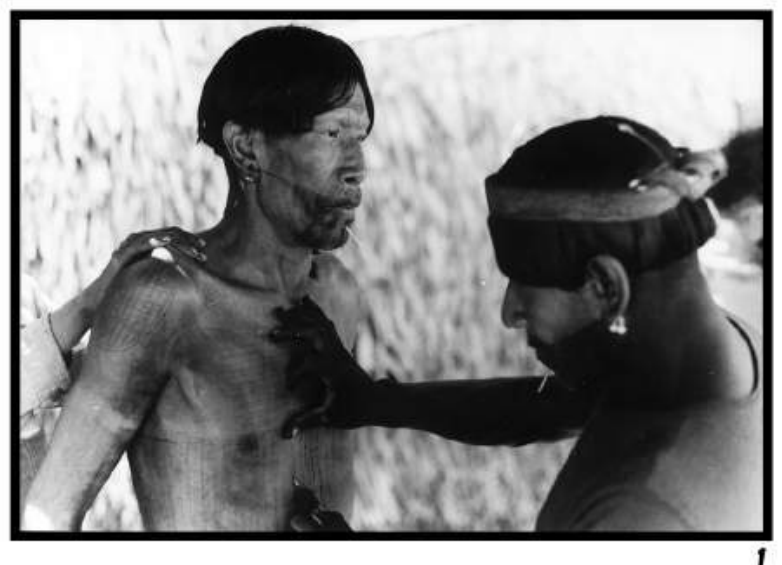

"Boakara" (posicão do guerreiro que é tatuado no ritual do Tauval.

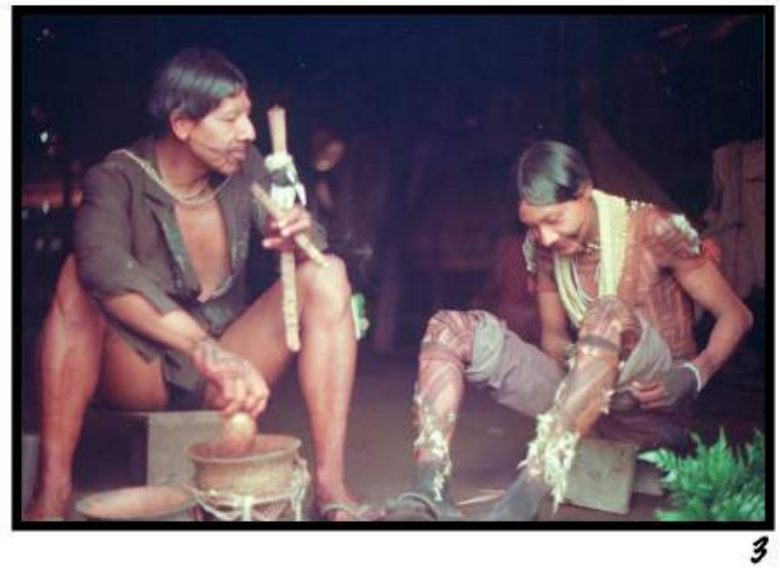

"Jesamere" (meu primo, l'iva) e "jera'yra" (meu filho, Tutē).

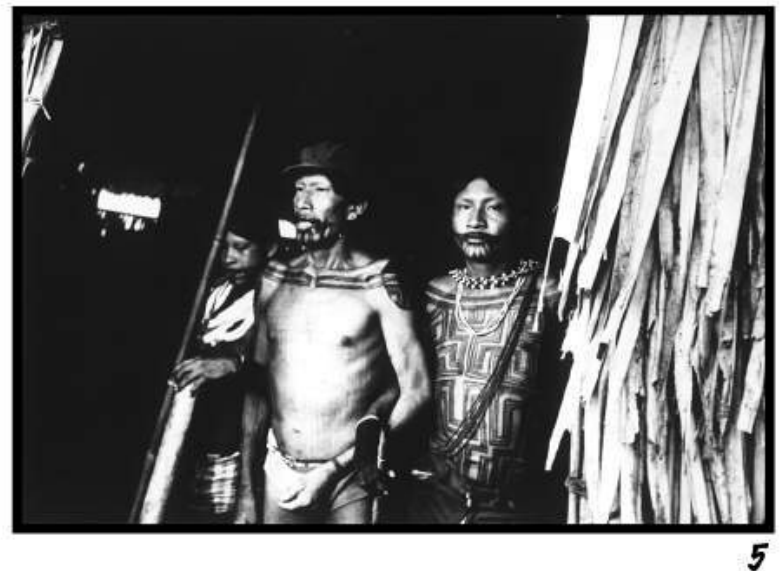

"Ga a'y. Marakauvarerakwara, mururuvara". (Ele é valente. Marido de Marakauvá é chefel.

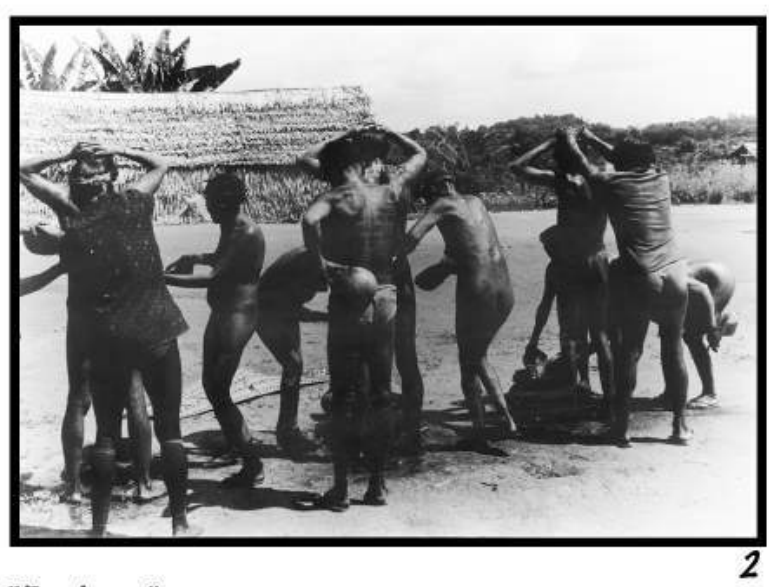

"Boakara".

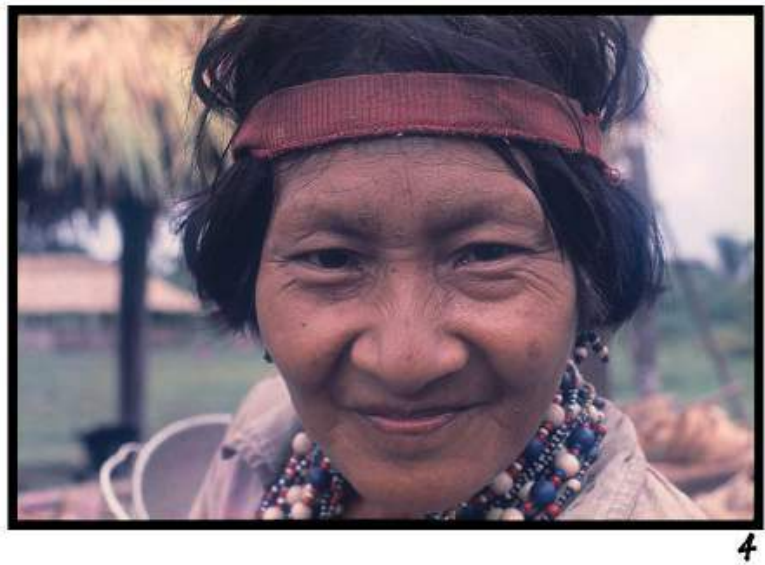

Jeremiriká (minha esposa, Mapurugi). Mure'yra pega a foto, separa e a coloca embaixo do braco.

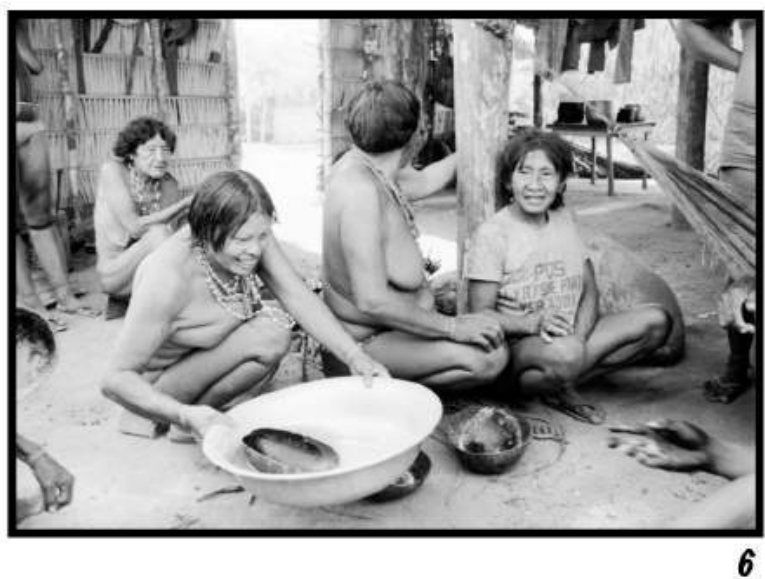

"Titia Tuvá, Ajui (atrás), Okina lao centro voltada para trás) e jeremiriká (minha esposa) Mapurugi (à direita) e outra jeremiriká, Miravô là esquerda seguranda a bacia)". 


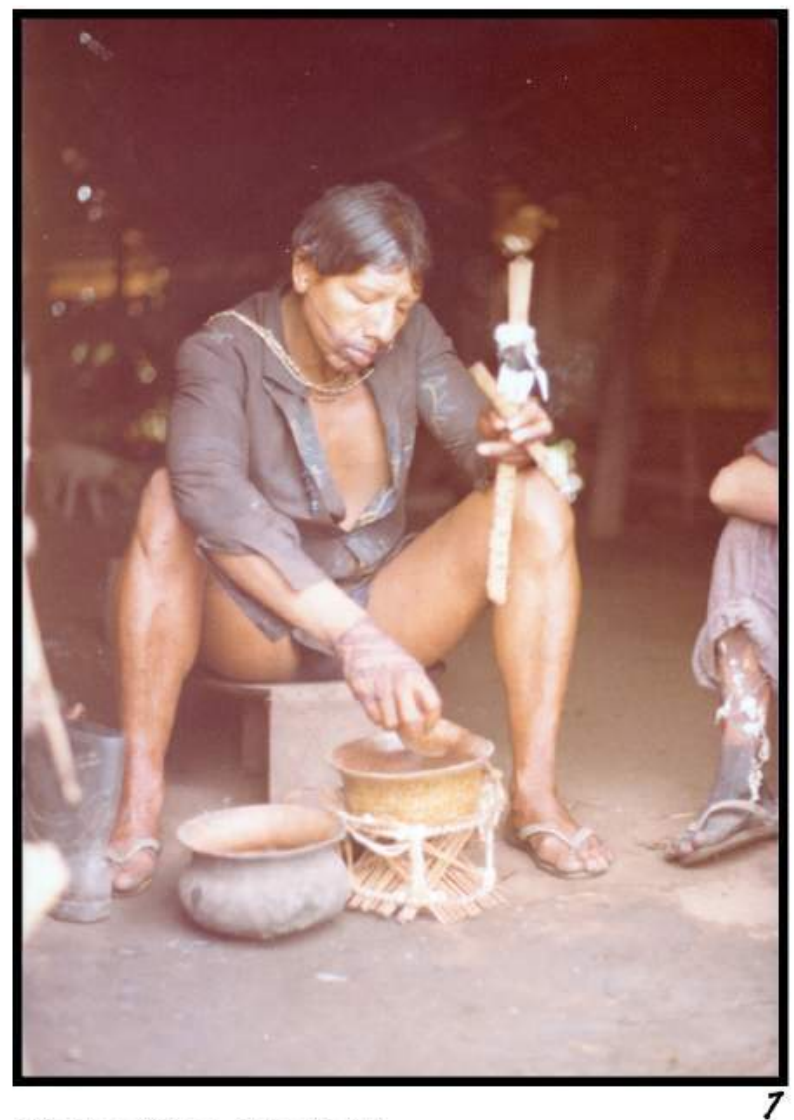

"Jera'yra" (mev filho, Tutē).

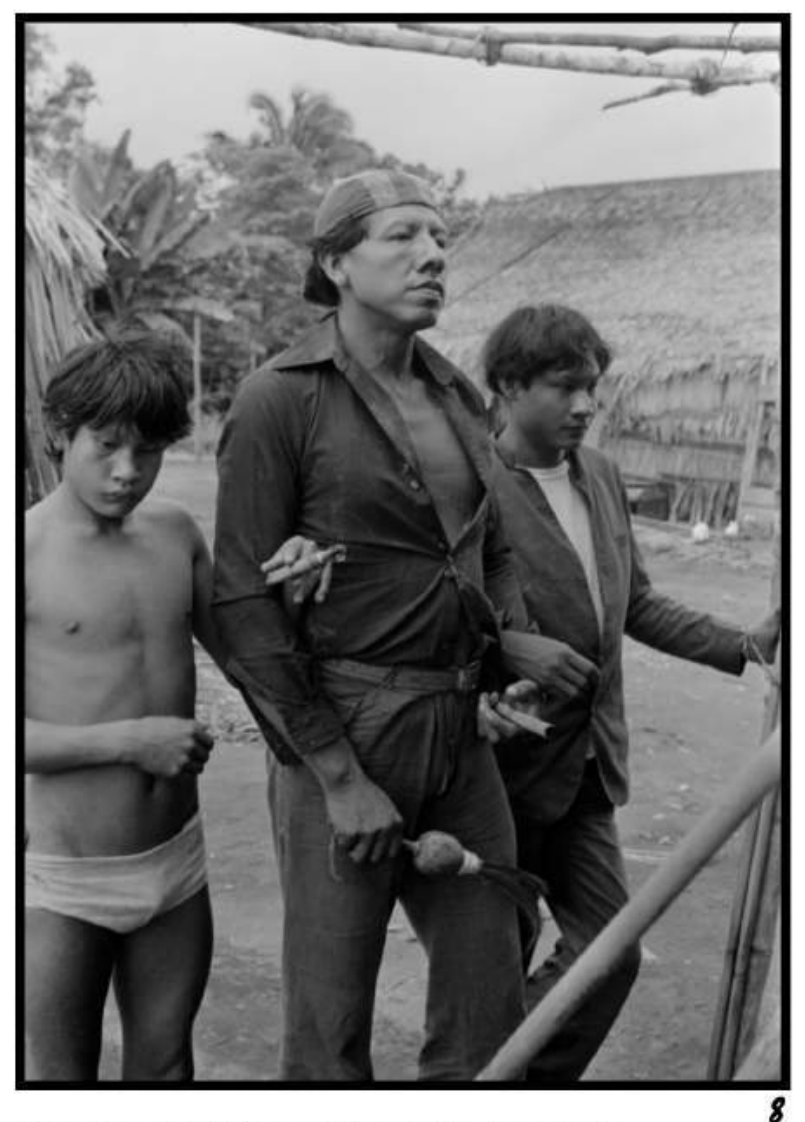

"Jera'yra, Tutē". (Meu filho, Tutē). Ao centro.

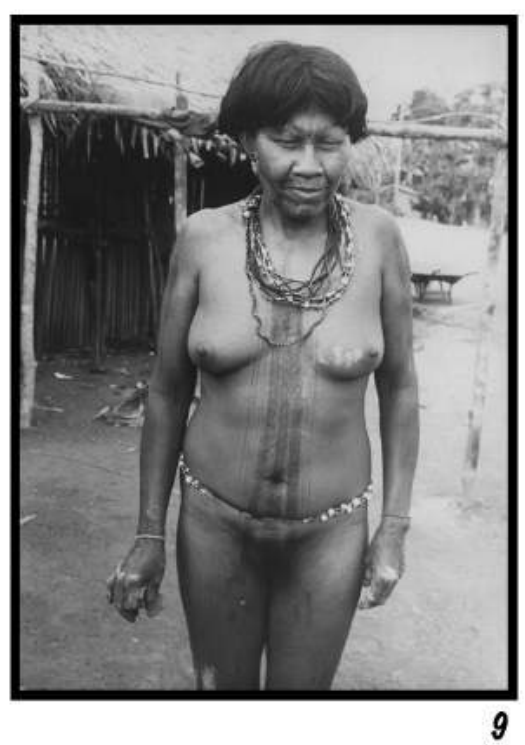

"Jeremiriká". (minha esposa, Mamari).

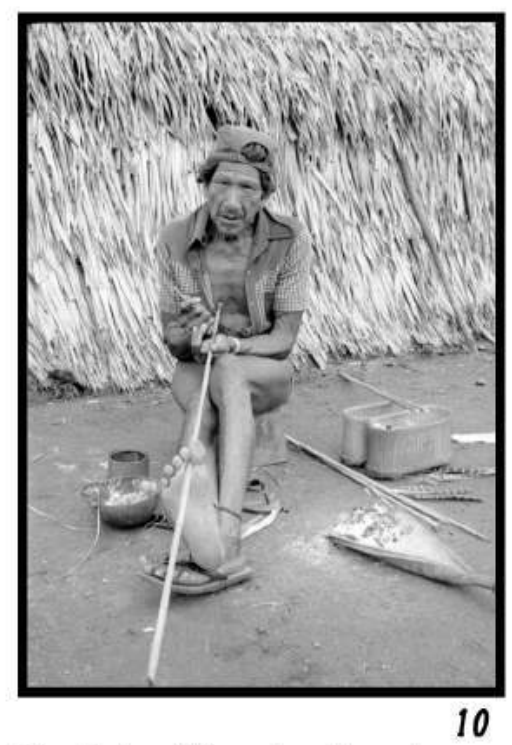

"Jereky'yra" (meu irmão mais velho, Kurijál.

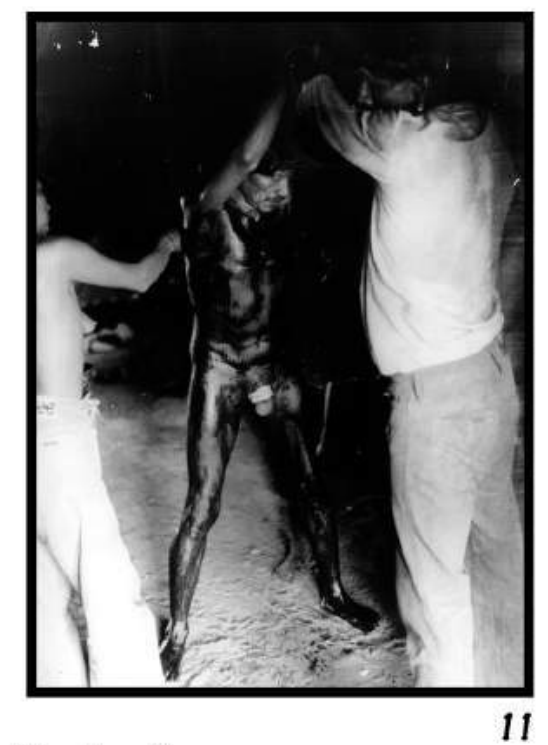

"Boakara".

Nas fotos 1, 2 e 11 Mure'yra menciona a posicão do guerreiro (moakara) nos rituais do Tauva e não os vínculos de parentesco com as pessoas retratadas. 


\title{
prancha 6
}

\section{Seleção Marakavá}

\author{
Fotos: Renato Delarole
}

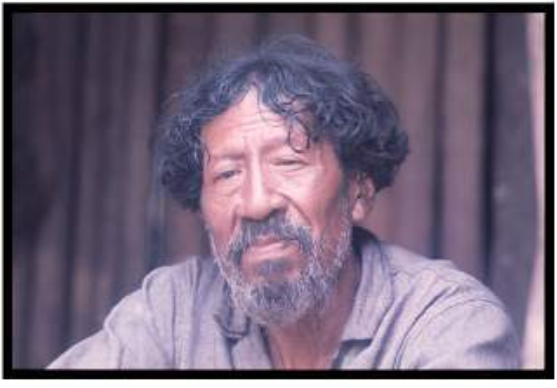

"Jetutyra (meu tio, irmäo da minha mãe). Morreu no Koatinemo Velho doente do ouvido. 0 nome dele é Panega'e".

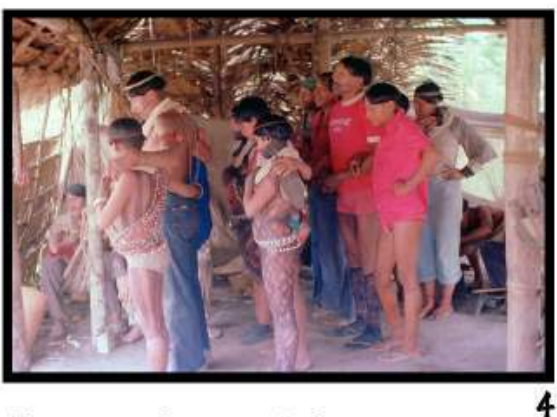

"Festa do Tivagava". Seus dois maridos na foto: l'iva, primeiro homem da terceira fila e Avona, terceiro homem da terceira fila (ambos de vermelho).

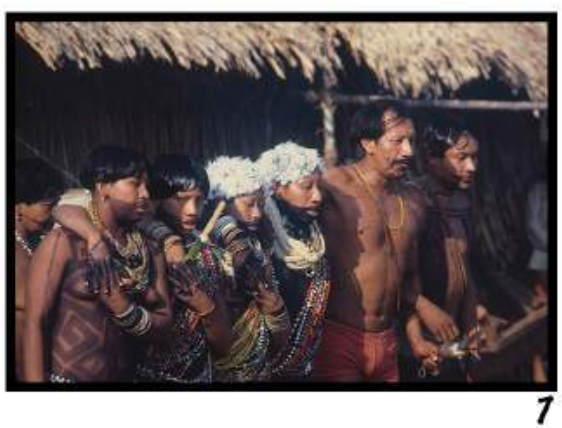

"Meus dois maridos na festa". Da direita para a esquerda l'iva e depois Avona abracado à Marakavá.

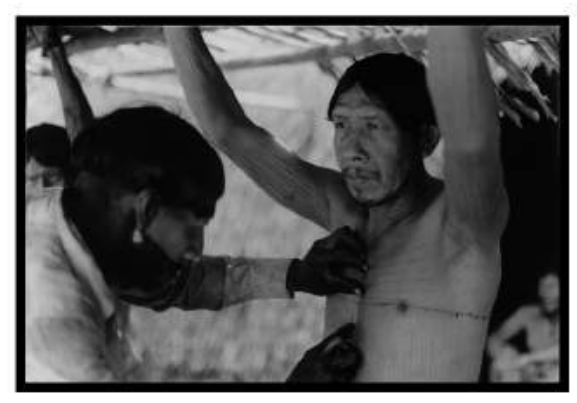

"À esquerda, "jesamere" Imeu primo), à direita, "jekyvyra (mev irmão)".

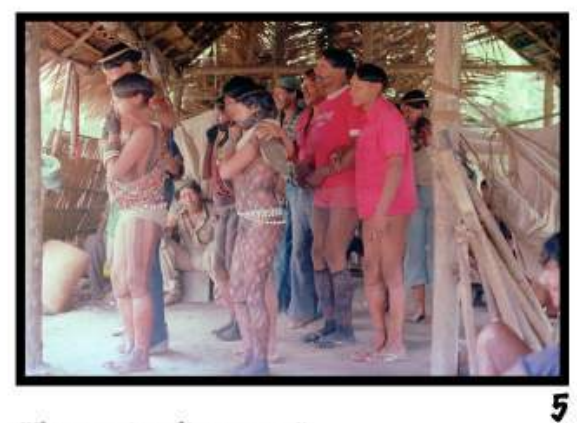

"Festa do Tivagava".

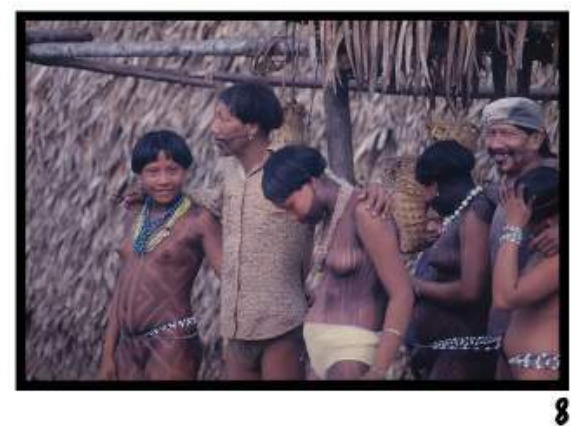

"Jeruvyra" (meu tio). Marido de Apeuna, Tataokaia.

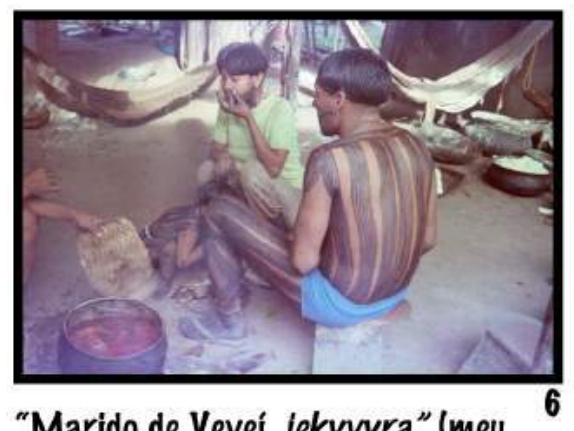

"Marido de Veveí, jekyvyra" Imeu irmāol.

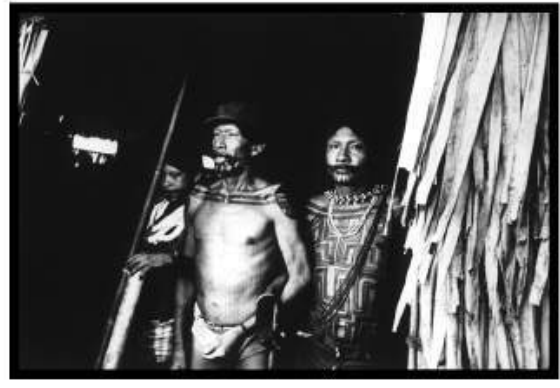

"Meu marido pintado dancando na festa".

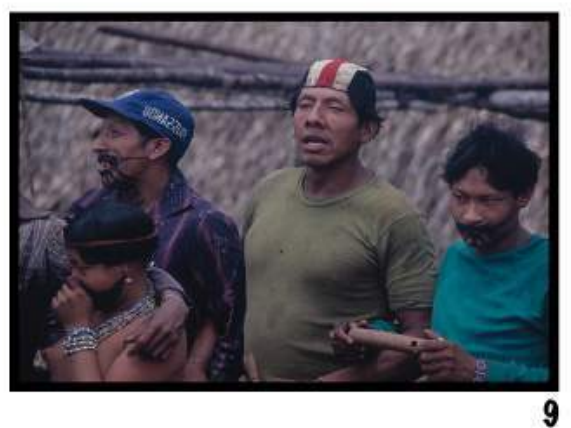

"Mukui jererakwara" Imeus dois maridos)". A direita l'iva e à esquerda Avona. 


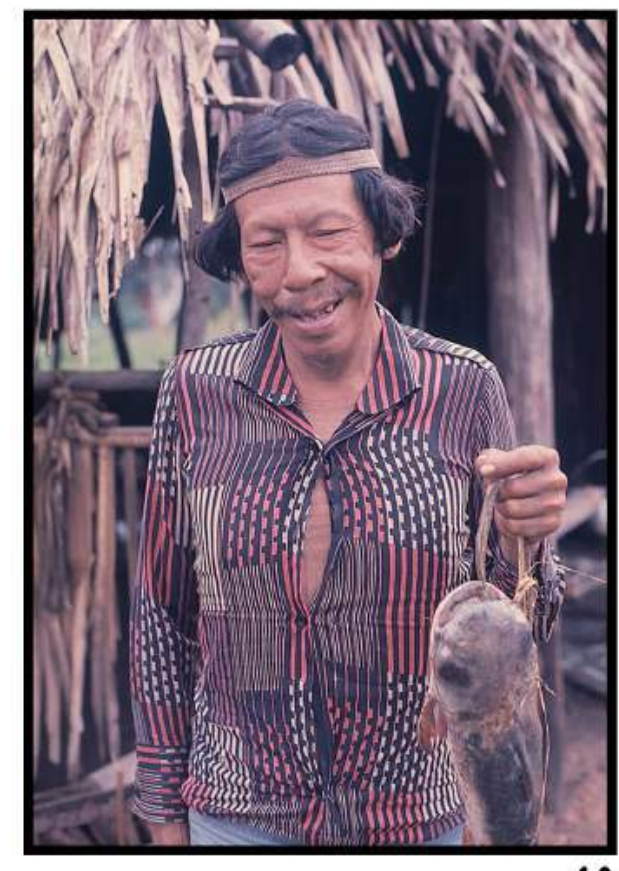

"Jekyvyra" (mev irmão, Juvá).

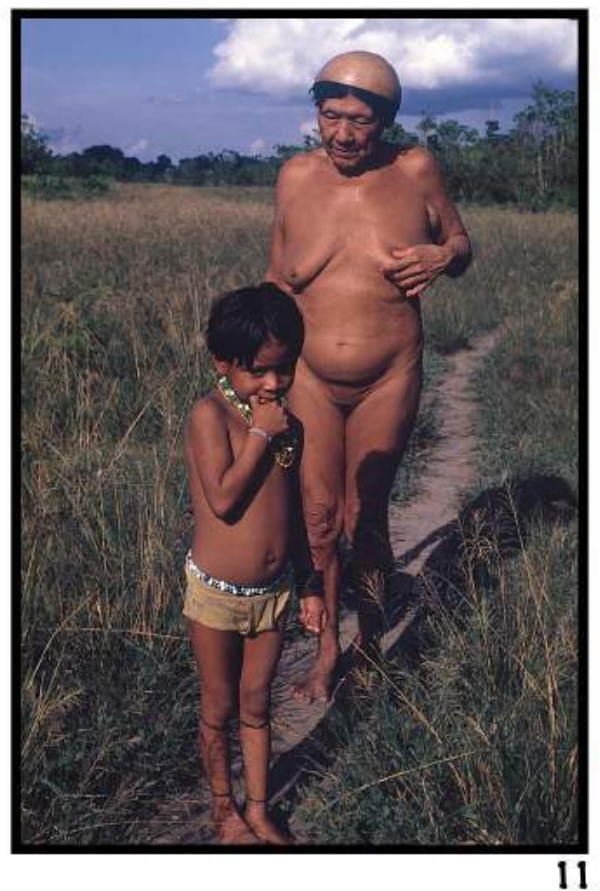

"Jehy'yra (minha tia, irmã da mäe). Tuvá e a tia (Ajuí) que criou ela".

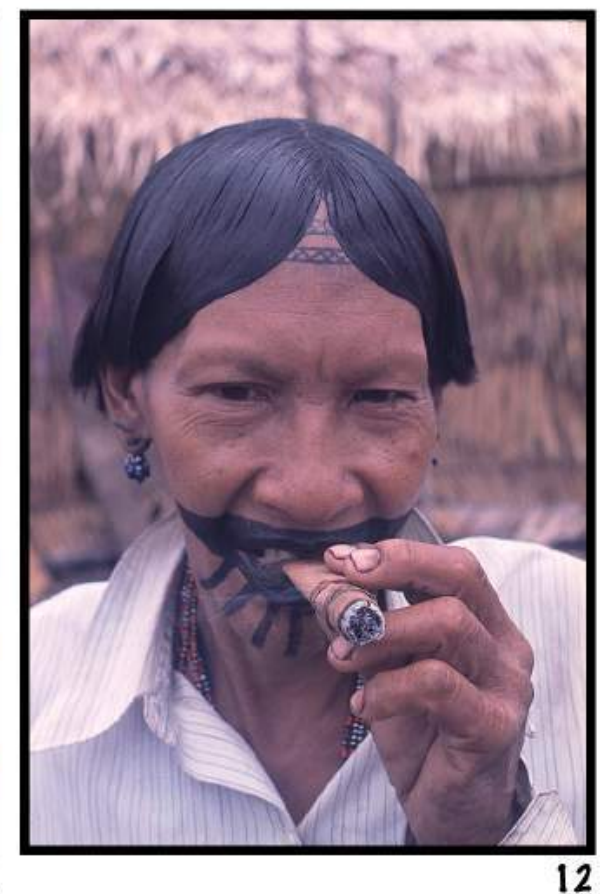

"Jehy'yra" (minha tia).

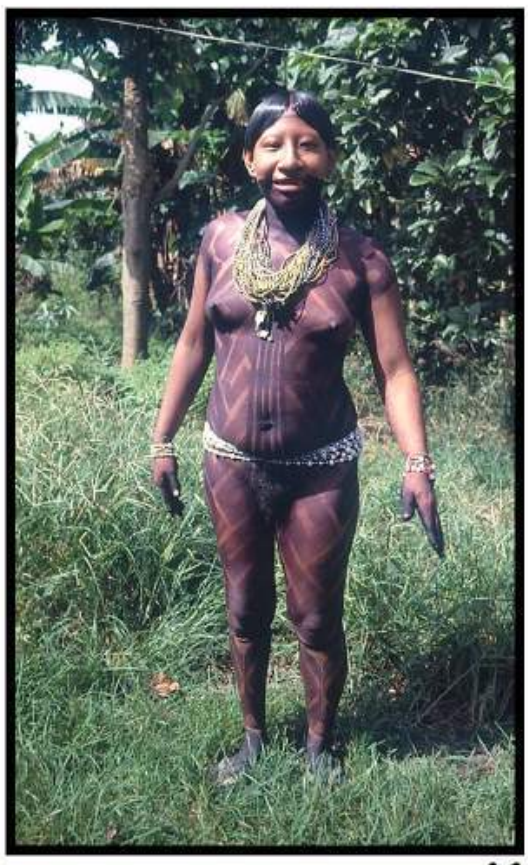

"Je" (eu).

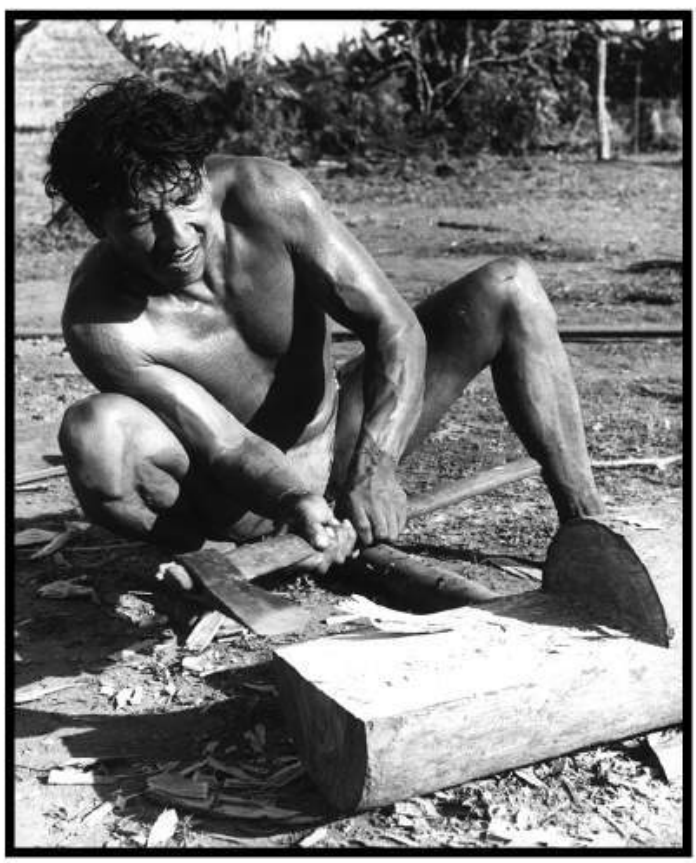

14 "Jesamere (meu primo), Capitão, depois Manduka virou Capitāo. Ele é mururuvara (chefe)".

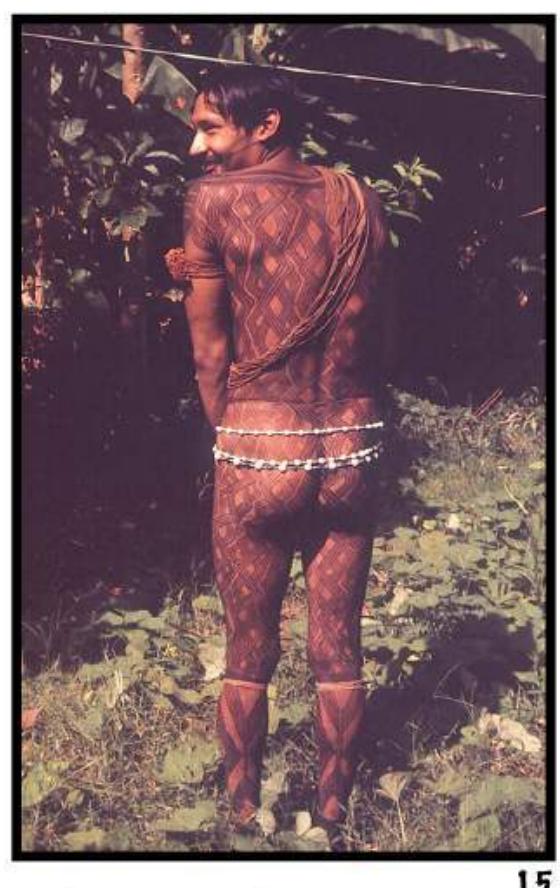

"Jererakwara (meu marido) com vergonha". 


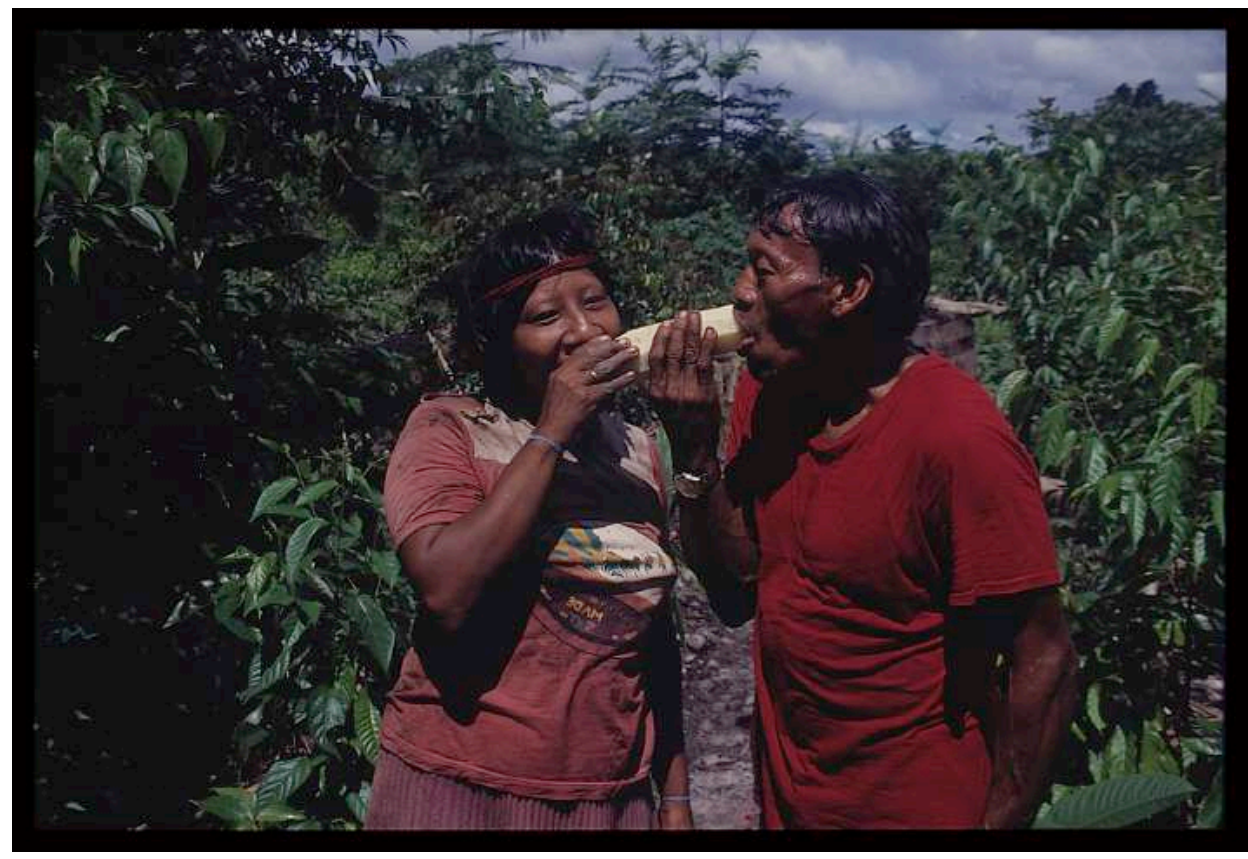

Imagem 8

Mure'yra e Marakauá posam para foto após arrancar mandioca na roça.

Foto: Renato Delarole.

A foto acima traz Marakauá e Mure'yra numa situação de descontração. 0 fotógrafo é cumplice do momento em que o casal brinca com a mandioca doce (maniakal) no retorno da roça. Quando, na casa dos dois, em uma das sessões com o acervo, eu me deparei com esta fotografia, separei-a de imediato. Talvez ela fosse umas das escolhidas por mim, num âmbito somente pessoal, por expressar um momento cotidiano em que o casal (que se tornou próximo a mim) se exibe em atitude carinhosa e posada. Mostrei a Marakauá esperando algum sorriso de aprovação, mas minha ação não teve efeito algum. O que ela queria ver eram as fotografias dos seus parentes "antigos", especialmente dos ex-cônjuges já falecidos, aos quais ela se referia como mukuĩ jererakwara, "meus dois maridos".

Dentre todas as imagens, escolheu uma. $\mathrm{Na}$ foto eleita (reproduzida a seguir), um bloco de seis pessoas dança durante ritual xamanístico. Marakauá está abraçada ao seu marido mais velho, Avona, que canta e toca o yapu, chocalho usado pelo pajé durante o ritual. 0 marido novo, I'iva, atua como ajudante do xamã (vanapy) e está posicionado do lado direito de Avona. Do lado esquerdo de 
Marakauá está Apeuna; ambas estão paramentadas com penas de gavião na cabeça pois atuam na função de uirasimé, mulheres cuja principal atividade na festa é preparar as refeições rituais - mingaus para os xamãs, participantes e espíritos. À esquerda de Apeuna estão Matuia e Mará, dançarinas que auxiliam no canto e na dança. Todas as mulheres estão enfeitadas com pinturas (juaka), colares de dente de macaco (kajyja), colar cruzado de miçanga (muyjuvaia), colar de cintura de miçanga (ka'apuava), maritá (pulseira de côco babaçu com osso de mutum, mytukyga) e brincos de miçanga (namikwayma). Todos dançam posando o olhar na altura do chão com expressão de concentração, e apenas Matuia olha para a câmera.

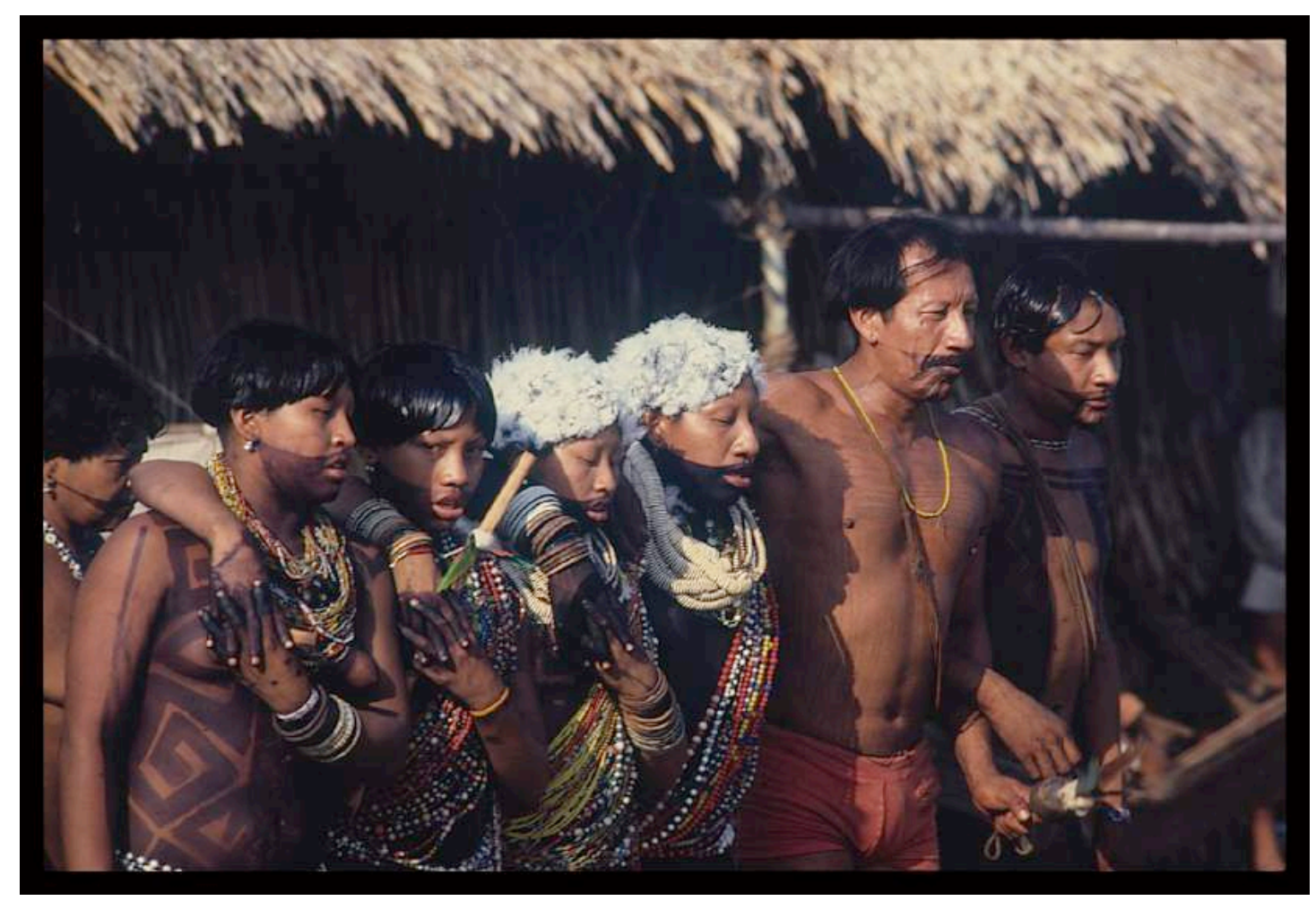

Imagem 9

Fotografia escolhida por Marakauá em sua seleção final. O homem de calção vermelho é Avona; ao lado direito dele, I'iva; ambos foram maridos dela. Foto: Renato Delarole.

No relato, incitado pela fotografia, Marakauá conta do casamento com os dois maridos retratados. Reproduzo a seguir o relato ${ }^{121}$ na íntegra, dada a riqueza de informações que apresenta.

121 O relato foi fornecido na língua asuriní e traduzido por Matuia. 
Jemyga'ara ${ }^{122}$, esse aqui que me criou [apontando para Avona na foto] ${ }^{123}$. Ele só dá comida primeiro pra mim, porque minha irmã [Moteri, hoje com 68 anos] largou ele. Aí ele ficou sozinho, ficou triste, sente falta dela, não fica quieto. Foi atrás de tapy'yia [branco]. Tapy'yia atirou nele e quase mata. Aí meu pai falou pra minha irmã: "Por que tu deixou ele?". Aí meu pai chamou ele [Avona] e disse: "Fica com essa minha filha mais novinha, vê se ela vai te deixar também". Aí ele vem, ficou comigo, só que nem como filha até eu ficar moça. Aí eu fiquei moça e fiquei com ele por muito tempo. Juntei com ele lá no Ipixuna, fiquei um "tempão" com ele. A gente fazia muita festa lá; aí viemos. Aí Araweté só ficou brigando com a gente. $\mathrm{Eu}$ vim duas vezes aqui na beira do Xingu com ele, ficava andando e roubando as coisas de branco beiradeiro que tinha roça. Nunca a gente separou. Aí padre Antônio encontrou ele. Lá no Koatinemo Velho, aquele marido meu, novinho [I'iva], foi meu marido velho [Avona] que chamou ele pra ficar comigo. Ele [marido novo] já estava rapazinho pra ficar comigo. Aí meu marido velho chamou ele pra morar com a gente porque ele queria casar com uma outra mulher nova ${ }^{124}$.

[...] Assim que era prometida [pro marido novo], o marido velho falou: "Tu vai ficar com esse homem quando ele ficar grande". Ele [marido novo] já tá rapazinho no Koatinemo Velho, já mora junto comigo. Ele ficou como que nem meu filho primeiro. Ele ficou rapaz e já estava namorando com outra mulher, foi atrás de Mará, Myrá, Murukaí, aí eu casei ele.

[...] Ele [Avona] falou pra mim: "Fica com esse novo que eu vou casar aquela menina [Kuipiuna] que já está moça da idade da Muruawi [se refere à filha da Matuia que tem mais ou menos 11 anos]. "Tá bom, eu vou ficar com ele, então", eu respondi. "Então deixa nós dois em paz, sem brigar, sem nada", eu falei assim pra ele [Avona]. Primeiro ele ficou com a mãe dela [Maia, mãe de Kuipiuna], aí meninazinha dorme junto que nem filha dele. Aí ele já estava namorando a avó de Apyrakamy [Maia] e quer vir me namorar. Eu ainda morava na mesma casa que ele. Aí ele briga de ciúme comigo, nóis [ela e marido novo] estamos deitados e ele quer brigar. Aí a mãe da Matuia [irmã de Avona, garendyra] vai e fala pra ele ficar longe de mim, que ele já tinha mulher nova. Depois que irmã dele falou com ele, aquele meu marido velho me deixou mesmo. Depois ele não briga mais comigo, eu só dava comida, ele conversava; eu soltei ele, ele ficou meio longe.

122 Müller (1993, p. 71) utiliza o termo jeremygara para designar "aquele que me criou". Acredito se tratar do mesmo termo, apenas com uma diferença no modo de grafar.

123 Algumas das informações adicionais entre colchetes, que visam auxiliar na compreensão do relato, foram fornecidas pela tradutora, Matuia.

${ }^{124}$ A tradutora, Matuia, explica que ele casou com a avó de Apyrakamy primeiro (Maia), criou a filha dela, Kuipiuna, e depois casou com a menina quando já estava moça. 
[...] Porque minha irmã deixou ele. Aí meu pai falou: "Não sei porque minha filha deixou esse homem porque ele é pajé, sabe tudo, trabalha duro". Eu fiquei com jemyga'ara; ele me pegou pequena até ficar moça, aí chamei ele de jemyga'ara. Assim que eu fiquei com ele, que meu pai que mandou.

0 relato de Marakauá é muito interessante pois, ao narrar em primeira pessoa os episódios envolvidos nos seus enlaces com os dois maridos, ela nos informa a respeito do modo como os Asuriní procediam tradicionalmente nos arranjos matrimoniais. Matuia, a tradutora do relato, explica: "Asuriní era assim: quando o homem queria mulher nova, primeiro ele tinha que ficar com a mãe, criar como filha a menina [filha da mãe] até ela ficar moça, depois casar com ela". Nesta relação, o cônjuge mais novo, homem ou mulher, chama de jemyga'ara quem o criou, e este utiliza o termo jeremymĩgá para se referir "àquele que foi criado por mim".

Uma relação privilegiada nesses tipos de aliança ocorre com filhos adotivos. 0 relato de Marakauá está cheio de bons exemplos. Seu marido mais velho casou com ela quando ainda era menina; assim, ele a criou como filha para futuramente tê-la como esposa. No entanto, ele decide se casar com outra moça mais nova (mãe de Apyrakamy, Kuipiuna) e, como a moça ainda era muito nova, ele casa com a mãe dela (avó de Apyrakamy, Maia), cria a menina como filha adotiva e, depois, quando está moça, casa-se com ela. Ao deixar Marakauá, o marido sugere que ela se case com seu filho de criação, I'iva, que se torna, então, o marido novo de Marakauá.

O casamento entre as jeremyga'ara e jeremymĩgá parece ter sido preferencial tradicionalmente. Müller (1993, p. 71) sugere que as regras de casamento entre os Asuriní estavam baseadas nas diferenças de sexo e idade e não na classificação dos indivíduos pelo parentesco. A união entre 'aquela ou aquele que me criou' e 'aquela ou aquele que foi criado por mim', com prioridade para o filho adotivo, filho da esposa ou do marido, era prática muito comum. 0 que acontecia com a pessoa, para ambos os sexos, era o seguinte: quando adolescente, casava com um cônjuge mais velho, e, quando maduro, contraía casamento com um cônjuge mais novo. 
Outro aspecto presente no relato é que os casamentos eram arranjados pelos pais dos cônjuges. Marakauá termina seu depoimento ressaltando justamente este ponto: "Assim que eu fiquei com ele, que meu pai que mandou". De acordo com Matuia, hoje quase ninguém aceita esse tipo de arranjo:

Se a família acerta assim, não dá certo. Foi assim que Mamari [mãe de criação da Mará, já falecida] carregou Kyraí para casar com Ajé [filho de Mará] e não deu certo, ele deixou ela. Parajuá [filho mais velho de Matuia] também foi acertado de casar com Parakakyja, e no começo ele não gostava dela não, custou a dar certo.

Atualmente, nos novos matrimônios, as relações jemyga'ara / jeremymĩgá foram praticamente extintas; os casamentos realizados nos últimos anos são monogâmicos e entre cônjuges da mesma faixa de idade. Apenas um homem maduro (33 anos) chamado Atyva seguiu esta regra, casou com uma mulher, Taymira (37 anos), e sua filha, Kereca (21 anos). Criou a menina e há cerca de cinco anos casou também com ela, ficando com duas esposas. Apenas Atyva e Takamuin (índio de 64 anos) possuem duas esposas. Este último casou-se com uma mulher nova de nome Tevutinemi (31 anos) há cerca de 18 anos e continuou casado com Ajuruí, sua esposa velha (68 anos).

Mure'yra, marido atual de Marakauá, assim como o seu primeiro marido (Avona), também é mais velho que ela. No entanto, o enlace dos dois não foi produzido a partir da relação jemyga'ara / jeremymĩgá. Após contar sobre os dois maridos presentes na fotografia, Marakauá descreve como foi que se uniu com seu atual esposo. O casamento aconteceu na aldeia Avasikirera, local onde moraram os Asuriní antes de formar o Koatinemo atual. Mure'yra, que liderou a construção da nova aldeia, saiu do Koatinemo Velho para fazer roça grande e logo em seguida mais gente veio atrás, assim formaram o Avasikirera. Marakauá conta que, quando perdeu seu marido novo (I'iva), não queria outro casamento. Apijava, casada com Yru (filho de criação de Marakauá e Mure’yra), explicou que, na época, ela não precisava mesmo de marido, "[...] porque quando era nova fazia tudo igual homem, caçava, pescava, atirava". Depois de muita insistência ela aceita casar com Mure'yra, mas se impõe de forma vigorosa a fim de evitar 
manifestações de ciúme e abusos de força física para com ela, o que, segundo relata, eram práticas comuns entre os casais ${ }^{125}$.

Marakauá e Mure’yra criaram Yru, filho da esposa nova (Kuipiuna) do marido velho de Marakauá. Esta foi outra história desdobrada da memória de Avona. Como ela mesmo relata, Avona se casa primeiro com Maia e cria a filha dela, Kuipiuna e, quando a menina se torna moça, casa-se também com ela. Com Kuipiuna tem uma filha, Apyrakamy. Após a morte de Avona, Kuipiuna casou com um Parakanã e engravidou de Yru. Quando Yru era bem pequeno, Kuipiuna ficou muito doente por conta de malária; ela foi para a cidade se tratar e acabou falecendo. O pai de Yru voltou para a aldeia Parakanã e Mure'yra, esposo de Marakauá, pegou o menino para criar. A avó de Yru, Maia, morreu depois da filha, Kuipiuna. Marakauá chama Maia de jerekyra, irmã mais velha.

A morte de Avona foi um evento significativo e marcante na memória de muitos Asuriní. Segundo relatos, morreu assassinado de maneira trágica: teve seu braço cortado com um facão por um índio de outra etnia que passava uma temporada na aldeia Koatinemo Velho. 0 motivo da briga foi a disputa por Maia, então esposa de Avona. 0 índio, que os Asuriní chamam de "Uaurá", perdeu-se do seu povo e foi trazido pela Funai para se ver se "era parente" dos Asuriní. 0 incidente trágico obrigou Uaurá a deixar a aldeia. Consta no Livro de Registro Administrativo de Óbito de Indígena nº 12 que, no dia 3 de outubro de 1989, faleceu Avona Asuriní, "acidentado por outro índio, 'decepando o braço esquerdo'". O corpo foi sepultado na aldeia Koatinemo Velho dois dias depois.

\section{$\underline{\text { Um destino incerto }}$}

As histórias sobre o paradeiro de I'iva, marido novo de Marakauá, apareceram quando ela viu uma fotografia em que o jovem todo pintado dança ao lado do pajé falecido Pinasiré, atuando como seu ajudante (posição de vanapy).

125 Embora eu não mencione aqui, ouvi de algumas mulheres muitos relatos de relações conjugais envolvendo ciúmes, disputas e brigas, o que inclui os casamentos com mais de um cônjuge. 
Olhando atentamente para a imagem (imagem 10, reproduzida a seguir) ela conta:

Meu marido novo era valente. Ele fazia muita coisa, banco, arco e flecha, mombaka [colar de osso de mutum e côco] pequenininha, era rico demais. Akaraí levou ele pra Belém. 0 chefe de posto [da Funai] levou ele porque ele estava doente. Mas ele ficou sozinho em Belém. Ficou sozinho e outro akaraí roubou ele.

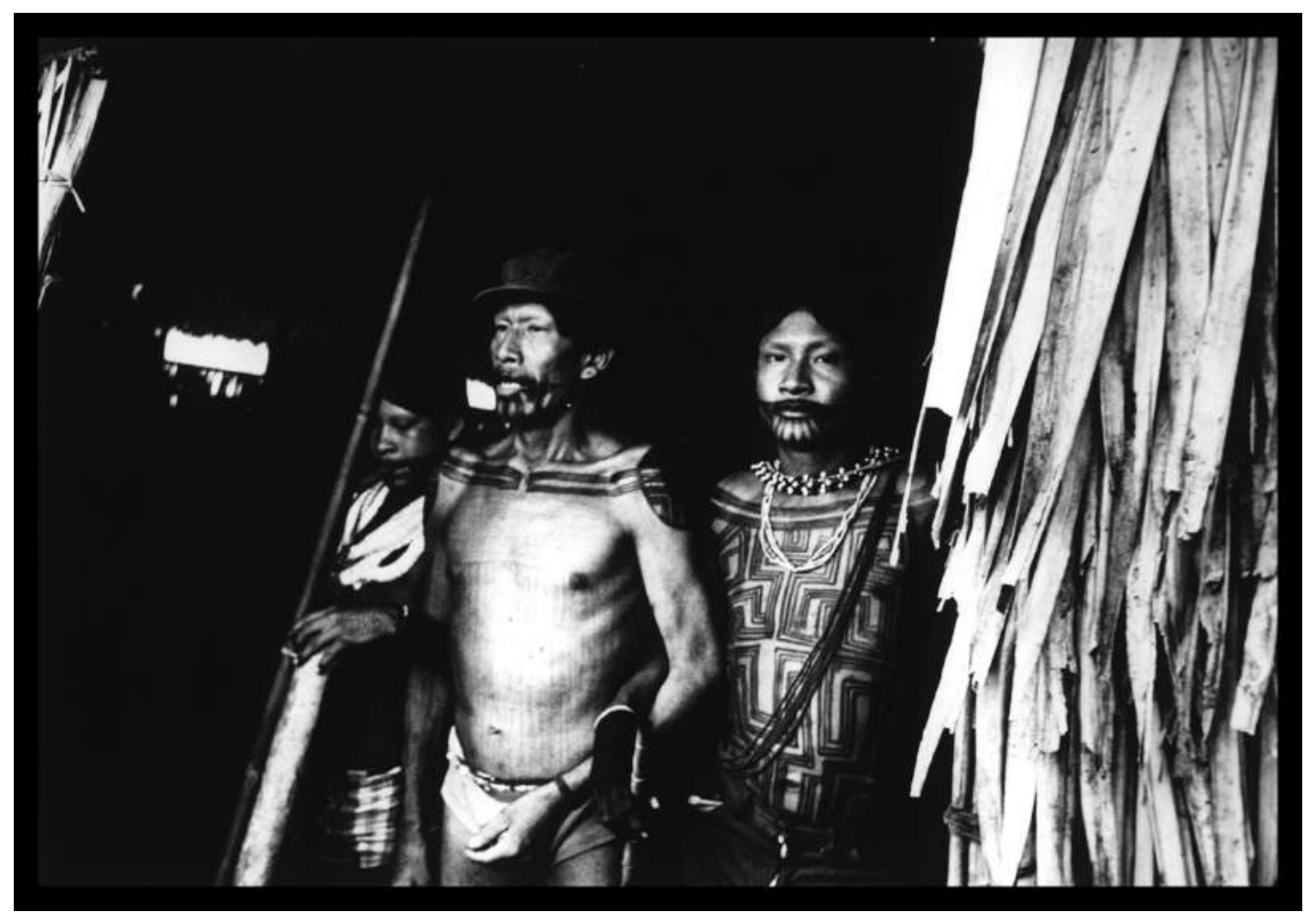

Imagem 10. I'iva todo pintado dança ao lado do pajé Pinasiré. Foto: Renato Delarole.

As fotografias em que I'iva é retratado não foram comentadas apenas por sua ex-esposa; praticamente todos que o conheceram e com ele conviveram se manifestaram de alguma forma. "Esse aqui é que ninguém sabe pra onde ele foi", disse Turé, mulher de cerca de 40 anos. Alguns me asseguraram que I'iva casouse com uma índia Munduruku, que conheceu na Casa do Índio de Belém na ocasião em que foi se tratar, e que hoje mora entre os Munduruku do Pará. Outros disseram que ele morreu e foi enterrado em Belém. 0 que abre mesmo margem para diversas versões a respeito do paradeiro de I'iva é o fato de seus ossos nunca terem chegado até a aldeia para serem enterrados na tavyve; em vista disso, como ter certeza de que ele está morto? 
prancha 7

\section{Retratos de l'iva}
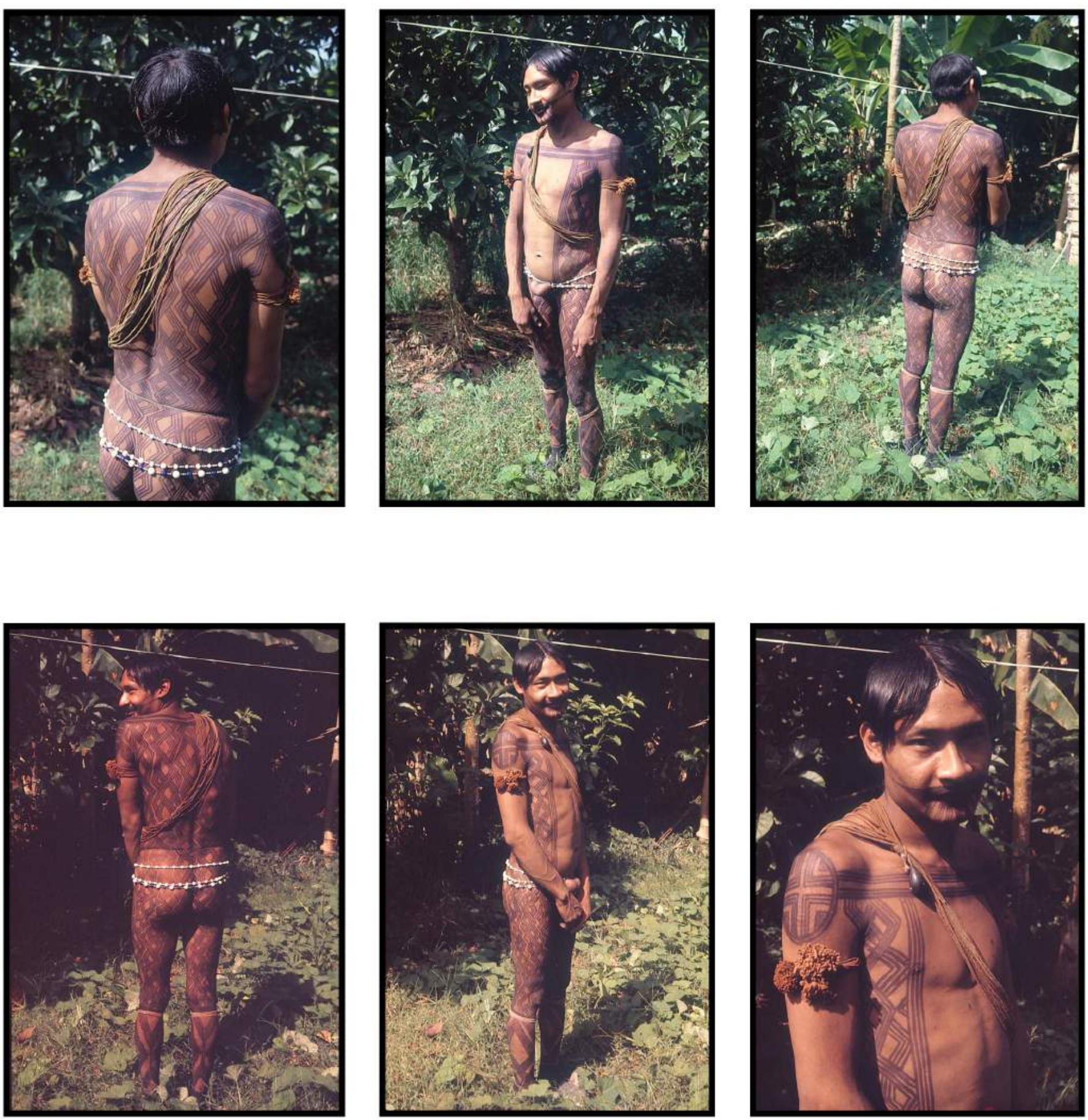

Fotos: Renato Delarole 
Após ouvir o relato de Marakauá e escutar diversos comentários de outros Asuriní, encontrei no Livro de Registro Administrativo de Óbito de Índio ${ }^{126}$, que fica guardado no posto de saúde da aldeia Koatinemo, a ficha que ajuda a traçar o destino do índio desaparecido. Consta no livro que no dia 11 de janeiro de 1985 "[...] faleceu o índio I'iva Assurini de encefalite aguda no Hospital Barros Barreto em Belém". No campo "Observações" aparece: "Idade aproximada 23 anos, era casado com Marakauá, não deixou filhos". Segundo o documento, o corpo foi sepultado em Belém no dia 12 de janeiro do mesmo ano. Quem assina o Registro é Napoleão Solimões Filho, então chefe do posto da Funai na aldeia Koatinemo Velho, no dia 16 de fevereiro de 1985.

De posse dessas informações, procurei Marakauá para preveni-la sobre o que eu acabara de saber. E foi então que eu conheci sua versão, a respeito do destino de I'iva, de maneira aprofundada. 0 que teria acontecido, segundo ela, é que o índio desapareceu na ocasião em que Solimões, chefe de posto que levou I'iva para tratamento em Belém, saiu para comprar uma refeição para ambos, deixando-o sozinho. Solimões retornou à aldeia sem I'iva e contou aos Asuriní que a situação da saúde dele havia piorado, levando a óbito, e que o corpo teria sido enterrado em Belém. 0 chefe de posto trouxe os pertences de I'iva (dentre os quais roupas, espingarda e lanterna) para a aldeia e os entregou a Marakauá, aconselhando-a para que os guardasse. No entanto, Marakauá destruiu tudo, menos a lanterna e a espingarda, por insistência de Solimões. A recém-viúva foi até a roça do marido e tirou todos os pés de melancia e mandioca que haviam plantado juntos; ela disse: "Eu piquei tudo e deixei lá".

Apijava, nora de Marakauá, que acompanhou o relato da sogra, interferia na conversa sempre que queria me explicar algum aspecto da sua fala. Neste momento, ela esclarece: "É porque Asuriní é assim, quando uma pessoa morre a gente tinha que jogar tudinho dela". Para fazer com que eu entendesse melhor, ela contou que sua mãe, Taymira, que perdeu um bebê de aproximadamente um ano há cerca de oito meses, enterrou todos os pertences da criança na cova aberta para seu sepultamento dentro da casa grande da aldeia do Ita'aka. "Minha mãe jogou os pacotes de fralda fechados no buraco" e, além disso, deixou o

126 Registro Administrativo de Óbito de Índio no. 06, página 02. 
salário-maternidade, auxílio que as mulheres recebem do governo federal por bebê nascido (cerca de R\$2.000), na lixeira do hospital em Altamira - PA. "O resto que sobrou, que não deixou na lixeira do hospital, ela jogou no buraco do caixão".

Conta Marakauá que I'iva era uma pessoa muito dada, gostava de conversar com todos e os brancos, logo que o conheciam, afeiçoavam-se a ele: "Por isso que roubaram ele em Belém". Quando Solimões retornou sem o índio para o Koatinemo, ela conta: "Alguém ouviu ele dizer para a irmãzinha ${ }^{127}$ que no caixão dele só tinha papelão". Marakauá especula: "Roubaram ele ou foi também que ele se casou no Munduruku. Lucineide [índia Munduruku que vive entre os Asuriní] disse que tem um Asuriní lá".

As evidências de que I'iva está vivo são muitas. Apebu conta que teria visto o índio na ocasião em que andou pela área procurando macaco entre os igarapés Ipiaçava e Piranhaquara:

Aquele homem veio para marcação da terra com CNEC128. Tinha muito akaraí. Eu falei com ele. 0 nome dele que os akaraí chamavam era Benedito. Ele perguntou da mulher dele e eu falei que ela estava casada já com Mure'yra. Ele queria voltar se ela não tivesse marido. Ele não voltou.

Marakauá diz que I'iva queria mandar "as coisas" para ela, mas que, quando soube que estava casada, ficou com raiva e foi embora. Depois, quando Mure’yra estava com cancêr de próstata (há cerca de oito anos) e passou uma boa temporada em tratamento em Altamira-PA, I'iva teria voltado a rondar os Asuriní. "Ele voltou, não sei quem viu", diz a índia.

A causa da sucessão de eventos envolvendo I'iva tem origem na morte de seu irmão (Tataokaia). I'iva teria ficado muito triste com a morte do irmão.

\footnotetext{
127 Referindo-se a Edith, uma das duas missionárias do grupo Irmãzinhas de Jesus, que se estabeleceram entre os Asuriní do Xingu em meados de 1982.

128 Apebu se refere à equipe do CNEC - Consórcio Nacional de Engenheiros Consultores S.A. É sabido (Cf. Müller, 1993, p. 45) que a empresa realizou trabalho de campo na área de domínio dos Asuriní para estudos de inventário em vias de avaliar a viabilidade do projeto hidrelétrico na região do Xingu entre 1985 e 1986. Muito provavelmente é a este trabalho que está se referindo.
} 
Marakauá conta que ele "[...] não parava de chorar, aí cabeça dele começou a doer. Ele lembra muito do irmão dele. Ele tinha que esquecer porque estava ficando triste demais". Marakauá relata que, quando seu ex-marido sumiu, ela pensou muito nele, e continua, "[...] minha cabeça queria me matar, cabeça quer me matar. Eu fiquei triste, nem fazia comida, nem queria Mure'yra perto. Ele [Mure'yra] perguntava por que eu estava brava com ele, eu dizia que estava lembrando muito daquele meu marido". Os retratos de I'iva trouxeram todas essas histórias que acabamos de descrever, mas não a tristeza pela saudade do ente querido. Marakauá indica que as fotografias trazem "só a lembrança" dele, mas não o sentimento de tristeza: "Antes eu ficava triste, agora não".

\section{Tantos outros parentes}

Muitos outros parentes foram vistos e lembrados. Mas, para citar apenas mais dois casos, recorro às sessões de fotografias com Veveí, índia de aproximadamente 65 anos.

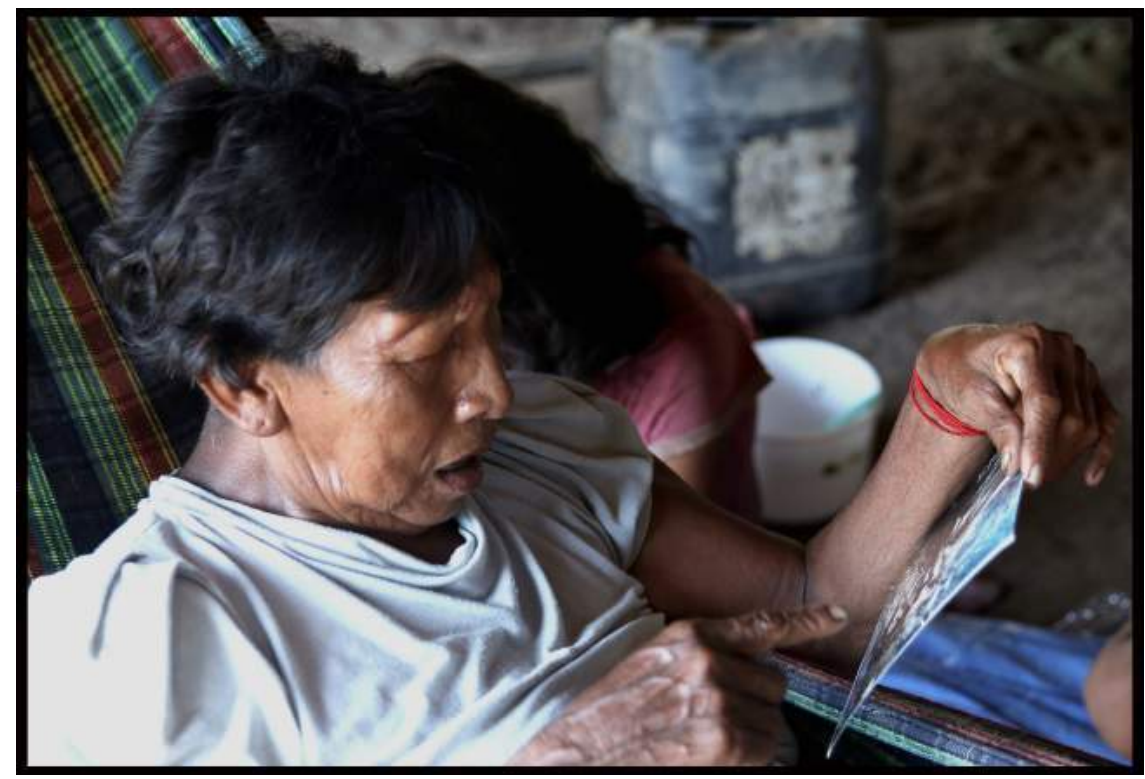

Imagem 11

Sessão de fotografias com Veveí. Foto: Alice Villela, junho de 2015. 
Veveí pediu que eu lhe mostrasse fotografias de seu marido falecido. Ao ver a totalidade das fotos do acervo, a índia separou, uma a uma, as imagens de seu ex-cônjuge (Momuna) e pediu de presente. Ela pegou o conjunto das fotos, abraçou e brincou dizendo que ia dormir com elas. A memória da morte trágica de Momuna veio à tona. Um dia ele foi para a roça e não voltou mais. Foi encontrado horas depois com um tiro na garganta. Os Asuriní localizaram a espingarda dele apoiada em uma árvore e o corpo no caminho para a roça. As diversas versões indicam que ele teria sido assassinado, mas cada uma possui um ponto de vista de quem seria o culpado ${ }^{129}$. A morte teria sido causada por uma disputa por mulher.

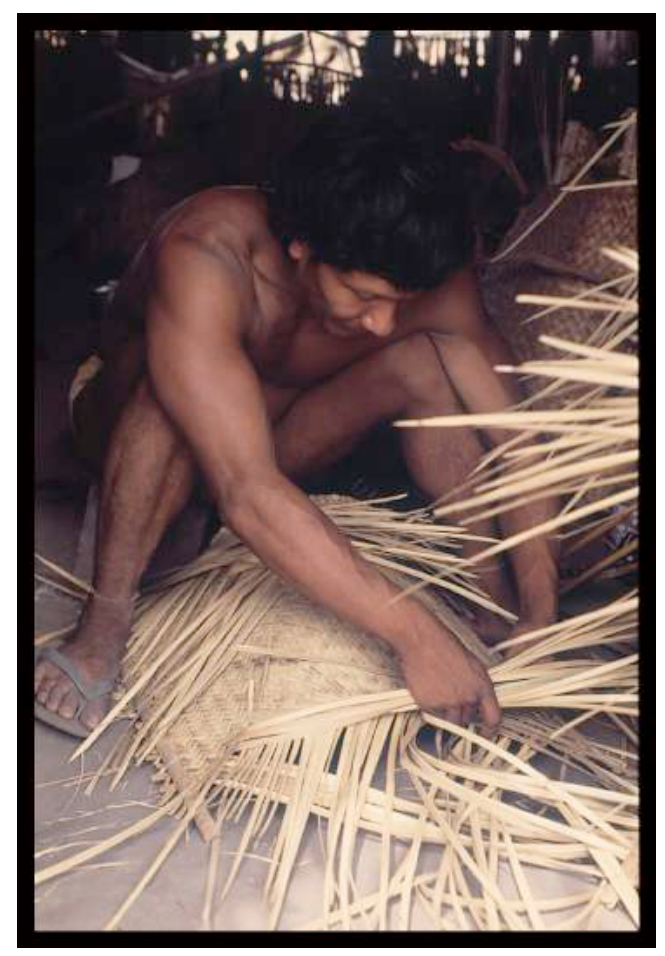

Imagem 12

Momuna. "Meu marido, eu estou com saudade. Eu quero mesmo meu marido", comentou Veveí ao ver esta imagem.

Veveí também quis ver e lembrar de Japepaí, sua filha com Momuna, já falecida. A fotografia trouxe a sua história. Quando tinha onze anos, Veveí deu a filha para uma parente de nome Tupaverí criar. Ela diz ter deixado a filha porque

${ }^{129}$ Os acusados são os próprios Asuriní ou índios de outras etnias que teriam brigado com Momuna na cidade. Não cabe mencionar nomes nem detalhes aqui. 
Japepaí tinha uma deficiência nas pernas e andava com o auxílio de muletas, e, como Veveí, já casada com Apebu, vivia fazendo expedições ao mato, não conseguia levar a menina ${ }^{130}$. Um dia, chegou na aldeia um índio Arara, de nome Ananum, à procura de uma esposa. Ele se casa, então, com Tupaverí, que a esta altura estava viúva, e passa a criar Japepaí, a filha de Veveí. Quando já estava moça, Japepaí casa-se com Ananum, com quem tem uma filha, Jejy'i. Quando Japepaí está grávida do segundo filho, Tupaverí faleceu. Japepaí ficou muito triste, chorava dia e noite a perda da companheira com quem dividia o marido. Ela chorou tanto que adoeceu e logo foi levada para a cidade. A índia não resistiu e ambos, mãe e bebê (bem pequeno, cerca de dois meses), faleceram ${ }^{131}$.

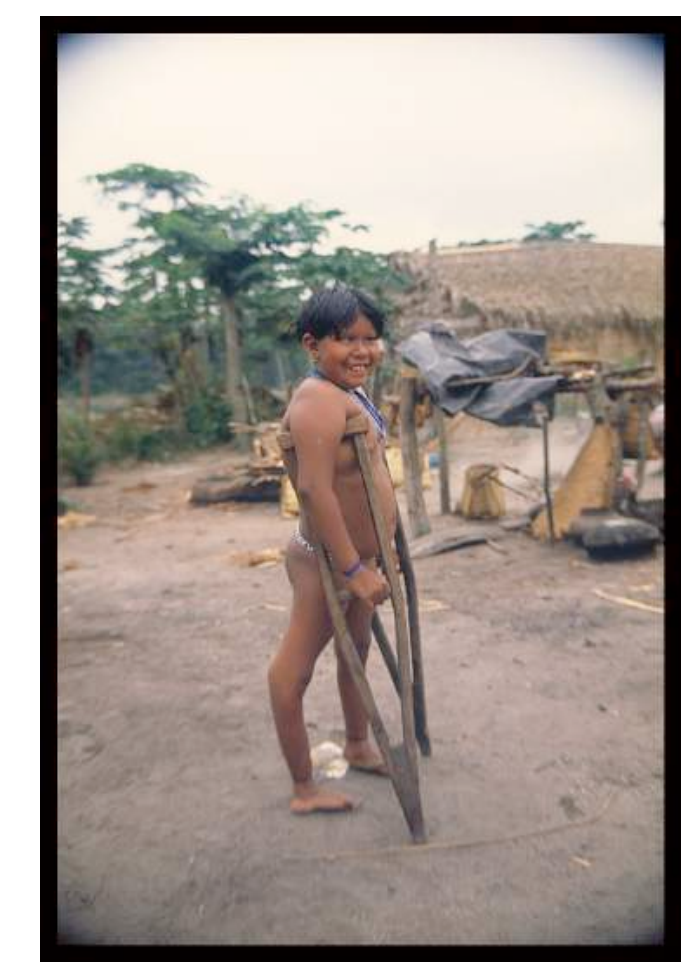

Imagem 13

Japepaí, filha de Veveí. Foto: Renato Delarole.

130 De fato, na etnografia de Müller (1993, p. 298), consta a informação de que, em 1977, Momuna mudou-se com a esposa, Veveí, e com a filha, Japepaí, que tinha aproximadamente cinco anos, para a casa de Tupaverí e Ivakaká. Residindo na mesma casa, Tupaverí passou a dividir os cuidados com a menina.

131 No Registro Administrativo de Óbito de Índio consta que Arare'a (outro nome de Tupaverí) Assurini faleceu no dia 27 de julho de 2004, em Belém, tendo sido sepultada dois dias depois na aldeia Koatinemo (Registro $n^{\circ} .01$ fl. 001), e Japepaí Assurini faleceu no dia 3 de setembro do mesmo ano (Registro no. 002, fl. 002) tendo sido sepultada no mesmo dia na aldeia Koatinemo, um intervado de dois meses entre um óbito e outro. 


\subsection{Ver e lembrar, lembrar vendo}

A conversa sobre a lembrança dos parentes amadureceu no dia em que Marakauá viu a seqüência de fotos do Tivagava. Ela escolheu duas entre as várias imagens da festa para integrar a sua série das quinze selecionadas (fotos 4 e 5 da prancha 6). As imagens retratam o ritual Tivagava dentro do complexo do Turé no momento em que os Kauirao - papel dos jovens iniciados - dançam abraçados às meninas (provavelmente vanapy do Tauva) e seguram o yapema, objeto ritual esculpido em madeira. Sobre estas duas imagens, ela comentou: "Gostei muito dessas aqui, tem todos os parentes". Entre as pessoas que mais gostou de ver retratados estão seus dois maridos, I'iva e Avona. Ela diz: "Bivé [antes] via foto de parente e ficava triste, agora não".

Marakauá explicou que, quando era nova e via fotos de pessoas já falecidas, ficava com muita saudade; agora, que está velha, não sente mais saudades; as fotografias evocam "só lembrança". Ao final da apreciação de todo o acervo de Delarole, ela relata que gostou demais de ver as fotografias dos parentes pois: "[...] hoje morreu tudinho, não tem quase parente vivo". Em outro contexto, o índio Takiri fez um comentário muito semelhante ao de Marakauá em relação ao mesmo acervo: "Gostei de ver o antigo porque pessoal já foi tudo embora".

Enquanto veem as fotografias, os Asuriní lembram dos parentes (jerea tejeta re'e, eu lembro dos parentes, ou jerea jereta re'e, eu estou lembrando dos parentes). "Ver" na língua asuriní é esak (aesak, eu vejo), o verbo é usado na linguagem corrente também para se referir à atividade exclusiva ao xamã quando visualiza seres e espíritos (pajé uesak, o xamã vê) durante o sonho e em suas viagens cósmicas nos momentos do ritual. É bom lembrar que a atividade de "ver" do xamã se constitui como uma verdadeira experiência - ele se casa e tem filhos no mundo dos espíritos, ao se transformar em um deles. Portanto, trata-se de um "ver" ampliado (ver aqui é conhecer, experimentar), diferente do ver cotidiano. Para se referirem à lembrança dos parentes, empregam a construção jerea jereta, na qual jerea quer dizer "eu lembro". Mas jerea também é empregado para denotar "meu olho" (por exemplo, jerea'y, meu olho dói). Assim, jerea pode significar "meu olho" e também "eu lembro", dependendo do contexto. 
Ter saudade dos parentes pode ser expresso da seguinte maneira: "Tejeta aesaka'u". Alguns Asuriní me explicaram que esse termo pode ser traduzido como "eu vejo longe". A partícula $a^{\prime} u$ é igualmente empregada no verbo sonhar, apua'u (eu sonho). Tal ocorrência é verificada em outras línguas tupi-guarani132, geralmente associada à atividade do sonho ou para designar situações outras em que haja a separação entre "alma/corpo". Em Araweté, a raiz a'o encontra-se no verbo para "sofrer saudade" (mo- $\left.a^{\prime} o\right)$ e no conceito de coisas perigosas me'e a'o, o que conota uma separação potencial entre um princípio espiritual e mental e seu suporte corporal, ou base físico-real. Dizem os Araweté que a saudade dos mortos-ausentes, manifestação da memória e da consciência, é algo que nos "despresentifica", mo-ao, "[...] separando nossa alma do corpo e tornando-nos translúcidos e leves" (Viveiros de Castro, 1986, p. 509).

Se tenho saudades, estou vendo. De outra forma, se estou lembrando, estou vendo. Seria demais arriscar dizer que lembro com meu olho, mas podemos declarar que para os Asuriní há ênfase no movimento simultâneo de lembrar e ver ou de lembrar vendo. Há, aqui, um destaque na atividade visual como artifício da memória. Creio que isto tem relação, pelo menos em parte, com o fato de que o meio de abordar e ativar memórias foi via imagens fotográficas. Os Asuriní também apreciam ouvir gravações de cantos rituais e toques de flautas turé para lembrar, tanto das seqüências musicais, quanto de pessoas e situações do passado, mas não tenho dados para avaliar que tipos de relações estas práticas poderiam engendrar na memória.

Embora Marakauá tenha dito que as fotos provocaram "só lembrança", sem tristeza nem saudade, Mure'yra, seu esposo, manifestou algo diferente em relação às mesmas fotografias. A imagem a seguir retrata Mamari, ex-esposa de Mure'yra quando nova. Essa foi uma das três escolhidas pelo velho para receber de presente e guardar consigo. Quando pedi para que Mure'yra falasse sobre Mamari e comentasse a foto, ele se recusou. Permaneceu olhando para a imagem e depois de algum tempo me disse que não queria falar porque poderia ficar

\footnotetext{
132 Mo-au, "sonhar" na língua wajãpi, o sufixo verbal $a^{\prime} u$ para "sonhar, conjecturar", a forma ma'e ra'u para "coisa de mau agouro" e a t-a'u-wer para "fantasma" em tenetehara. Para outros exemplos, ver Viveiros de Castro, 1986, p. 513.
} 
triste. Mamari faleceu nos últimos dez anos, mas parece que sua figura não foi suficientemente esquecida para poder ser lembrada via fotografia.

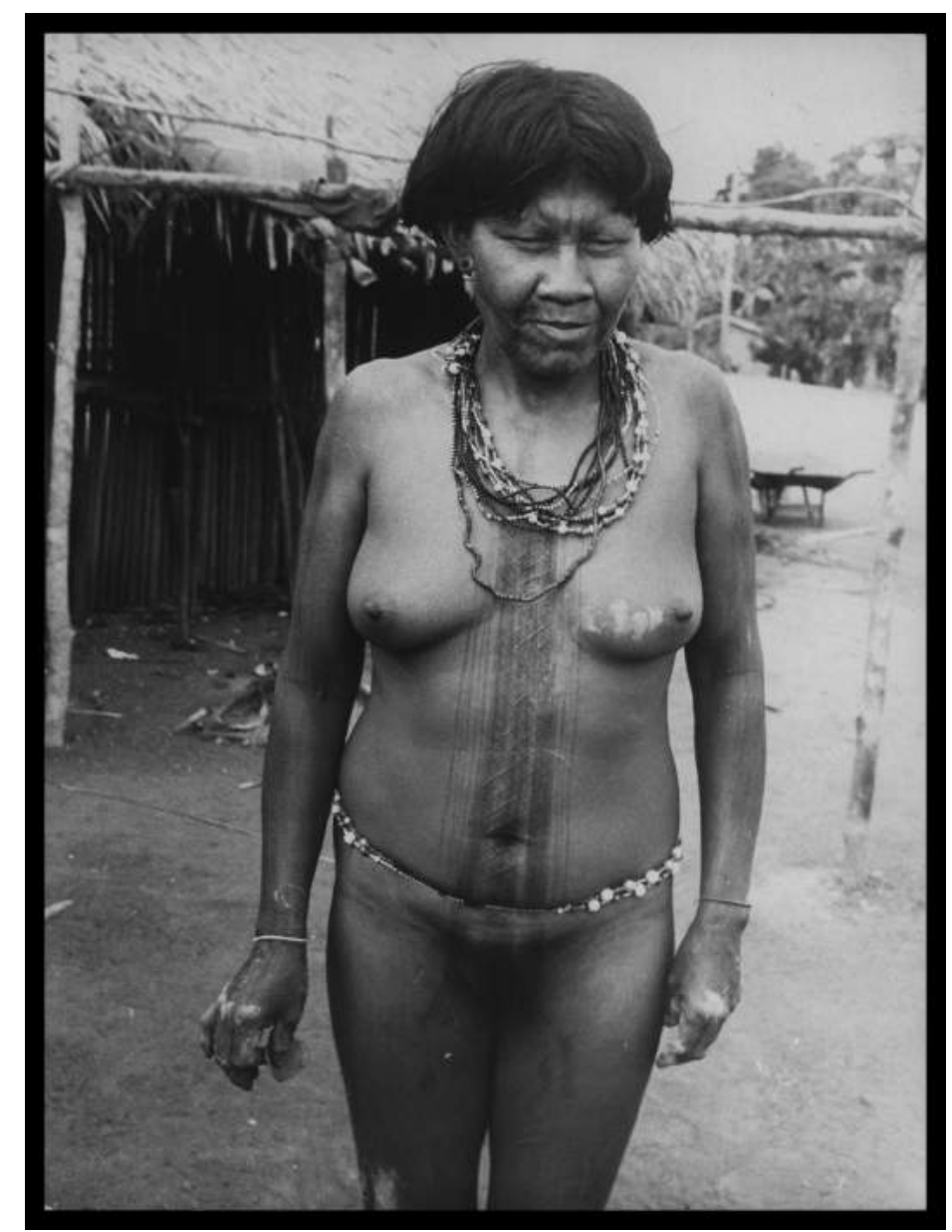

Imagem 14

Mamari, uma das esposas de Mure'yra. Foto: Renato Delarole.

Em suma, as fotografias possibilitaram, especialmente aos velhos Asuriní, ver e lembrar, ou melhor, ver e lembrar vendo. A saudade dos parentes pode gerar tristeza (ajemumy'a, eu estou triste), nos "despresentificar" e fazer que se adoeça. Boaiva, velho de mais de 70 anos, contou que um médico da cidade o aconselhou a não ficar triste pois poderia ficar doente: "Fica triste e o coração dói". A lembrança, a saudade e a tristeza podem andar juntas. Recordemos o caso de I'iva, que adoeceu depois de ficar muito triste com a morte do irmão, ou o episódio em que Japepaí ficou enferma após a morte de Tupaveri. Ainda hoje, as crianças que residem junto aos velhos são instruídas a respeito do perigo de se 
lembrar e ter saudade de alguém que já morreu, como demonstra a narrativa que Burí conta para a menina Muruavi, transcrita a seguir133.

Havia duas irmãs. A mais nova morre, deixando a mais velha sozinha. A irmã que ficou mora em uma casa com seu marido, mas sente muita saudade da irmã que morreu e adoece. Pede ao marido para buscar água para ela. Ele vai e pede para outro cuidar dela. Na ausência do marido, o anhynga da irmã falecida vem e a chama para ir no mato [ka'au]. A irmã não pensa duas vezes e segue o anhynga até chegarem na roça nova [ka'yau]. Enquanto isso, o marido volta, deixa a água, procura pela esposa e a encontra. Ele briga com anhynga. "Deixa ela" (ejiai ireī), ele diz. Ele é pajé e viu anhynga. Anhynga esqueceu a irmã. 0 marido fez petymbo ${ }^{134}$ para anhynga esquecer a esposa.

Conforme já foi abordado, o anhynga dos mortos são seus espectros que se tornam visíveis apenas para os xamãs. Os que não contam com as capacidades especiais escutam e sentem sua presença. Deste modo, a visão, sentido que é ressaltado pelos Asuriní na atividade de lembrar dos parentes retratados nas fotografias e que se estende, também, mas de outra forma, à capacidade dos xamãs, cede espaço para audição e olfato. A memória de uma pessoa comum a respeito da presença de anhynga não é, e não pode ser, visual. A presença de uma memória visual, neste caso, representaria um risco.

Ao que tudo indica, ver, seja lembrando com saudades ou vendo uma fotografia, pode ser perigoso em se tratando de parentes cuja morte acabou de acontecer. Na história contada por Burí, não apenas a irmã que ficou deve esquecer (jerea'it, eu esqueço) ${ }^{135}$ a falecida, mas também o anhynga da falecida precisa esquecer a irmã que permaneceu e deixar de persegui-la. Fotografias de pessoas cuja morte é recente representam um risco, bem como pronunciar o nome do recém-morto. A imagem, o nome e a lembrança do morto podem trazer seu espectro para perto dos seus parentes.

\footnotetext{
133 Contada por Burí e traduzida por Matuia, em novembro de 2012.

134 Principal rito dos rituais xamanísticos maraká.

135 Não foi possível identificar o que significa a partícula "it"; jerea, conforme foi apresentado, significa "eu lembro".
} 
Mas este não foi o caso das fotografias do acervo Delarole, que trouxeram memórias de parentes que faleceram há pelos menos dez anos, e não mais oferecem grandes ameaças; o caso de Mure'yra relatado anteriormente de fato é uma exceção. Bem aceitas, as fotografias circularam com extrema fluidez e sem restrições, principalmente entre os velhos, que foram ficando cada vez mais ávidos para vê-las, inclusive mais de uma vez. A prática de "só lembrar", explicitada por Marakauá, tira da fotografia a névoa de perigo e a investe de uma positividade digna de nota.

Em um contexto enormemente diferente do que viviam os Asuriní no passado, que pode ser caracterizado, grosso modo, pelo convívio intenso com os brancos, alterações na pirâmide populacional (três quartos da população asuriní são crianças e jovens, e pouco mais de uma dezena são velhos com mais de 60 anos), mudança radical nas regras de casamento, dentre muitos outros, a presença dos parentes via fotografia representou uma espécie de conforto (e refúgio) aos velhos, que têm dificuldades de compreender e de se situarem na atual conjuntura caracterizada por transformações profundas e aceleradas. 


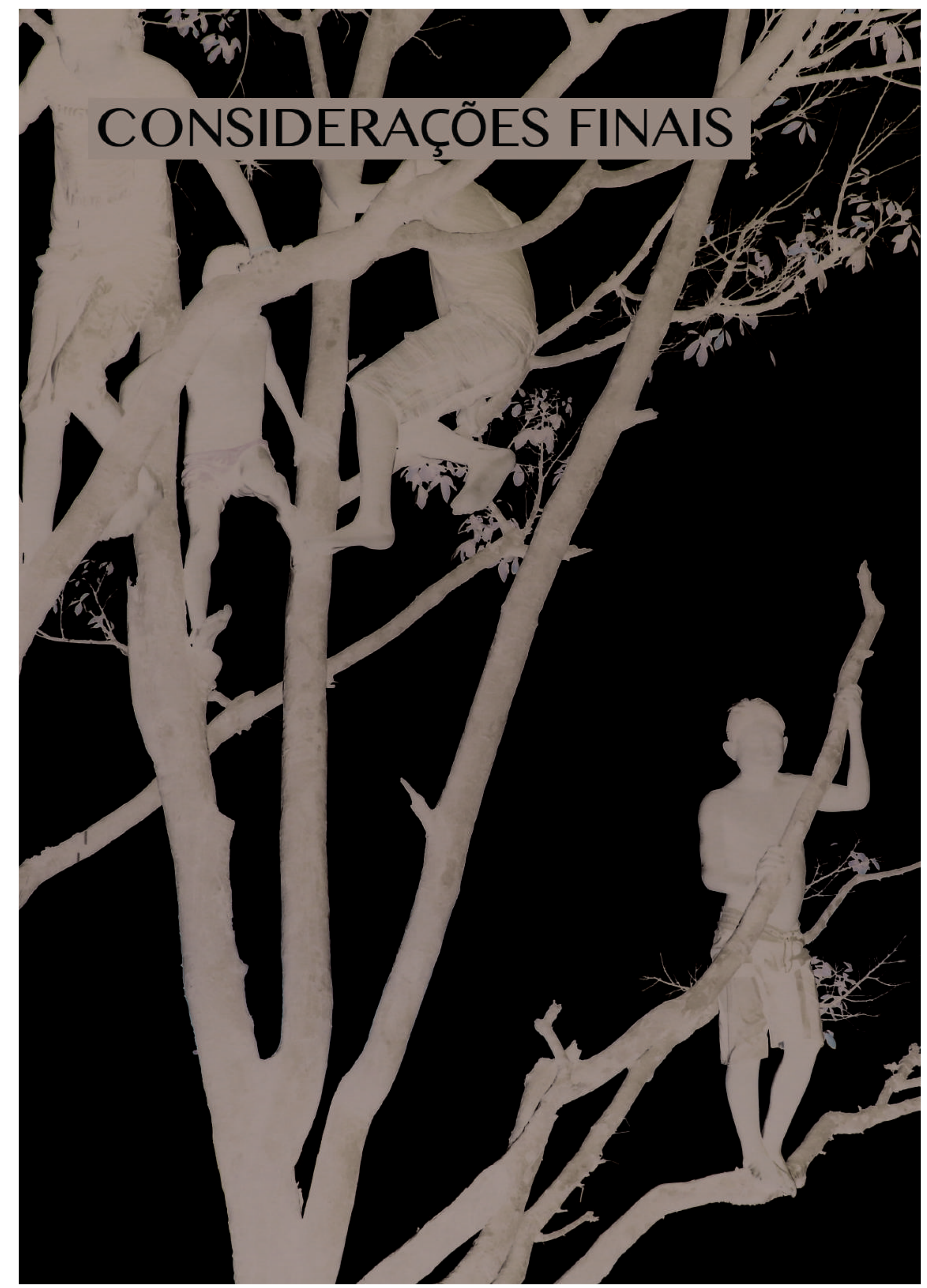




\section{CONSIDERAÇÕES FINAIS}

\section{O NEGATIVO E 0 POSITIVO EM TRANSFORMAÇÃO}

Do contato inicial aos dias atuais observamos uma mudança significativa na relação dos Asuriní com as imagens produzidas pelas tecnologias dos brancos. Se, no primeiro encontro com os padres católicos, a fotografia teria agido de modo patogênico, causando doenças e mortes, nos dias de hoje ela pode ativar memórias e lembranças de parentes falecidos, experiência que foi vivida de maneira positiva, tanto em relação ao acervo de Renato Delarole, quanto às fotografias produzidas por Anton Lukesch. Poderíamos presumir que a relação dos Asuriní com imagens fotográficas passou de algo nocivo, danoso e perigoso para o profícuo, benéfico e conveniente, ou do negativo ao positivo. Esse percurso pode parecer, a princípio, ser o fio condutor do argumento. Contudo, como se pretendeu evidenciar ao longo do trabalho, o que se verificou foi algo mais complexo do que pode parecer inicialmente.

Procuramos mostrar que a ideia da fotografia como objeto patogênico foi produzida a posteriori - anos depois do primeiro encontro dos Asuriní com a câmera dos padres - na situação em que se fizeram sentir seus efeitos nefastos (mortes e adoecimentos). As fotografias que integram o livro Bearded indians of the tropical forest registram índios à vontade, em poses e sorrisos, diante dos novos interlocutores. Como os Asuriní demonstraram em seus relatos, o contato com os brancos foi uma forma de pôr fim às guerras intertribais, consistindo em uma estratégia de sobrevivência. Portanto, mesmo que tenham desconfiado da fotografia desde o primeiro encontro com a câmera de Lukesch, sua presença foi tolerada como prática inevitável e necessária ao convívio com os brancos. No 
episódio do primeiro encontro, quem manifestou medo e suspeitou do funcionamento da câmera e das intenções dos padres foi um xamã, mas teria logo sido advertido por outros indígenas para que não protestasse.

A ambigüidade inerente à relação com a fotografia nada mais é do que a ambigüidade segundo a qual se relacionam com os brancos. Embora tenham deixado de ser chamados de tapy'yia, inimigos, passando a ser referidos como akaraí, com quem os Asuriní travam relações amistosas e de parceria, a desconfiança no trato com esses interlocutores está sempre presente. Como disseram alguns índios, "os akaraí estão mansos, mas estão ficando bravos de novo". A fotografia funciona como um objeto mediador da relação com os brancos e, por conseqüência, o modo como essas novas imagens podem agir causando efeitos está atrelado ao tipo de relação que se estabelece com seus produtores, o que varia, não apenas de acordo com o momento histórico em que estão vivendo os Asuriní, mas também na dependência de quem são os akaraí com os quais dialogam.

O que torna todo esse mecanismo mais complexo é o fato de os relatos sobre a relação com a fotografia no passado serem produzidos com uma ênfase no momento em que estão vivendo no presente. Um bom exemplo é que nos primeiros trabalhos de campo ouvi de alguns índios que a fotografia no contato causou mortes e adoecimentos (o que me fez supor que a agência das imagens partiu dos padres católicos). Na última incursão à área indígena identifiquei a produção de relatos com diminuição dos efeitos da agência da fotografia dos padres e hostilidade à Funai, ao afirmarem que as mortes e adoecimentos foram de responsabilidade da frente de atração do órgão indigenista (que assumiu o contato depois da partida dos irmãos Lukesch), cuja omissão e descuido para com os Asuriní foi determinante para o desastre populacional. A animosidade em relação à Funai se verifica no contexto atual em que, de fato, o órgão indigenista se encontra bem pouco presente no cotidiano da aldeia, num momento profundamente delicado caracterizado pela grande interferência, na região, do projeto de construção do complexo hidrelétrico de Belo Monte. Sem a Funai presente, os índios têm que articular e negociar diretamente com o consórcio 
construtor da Norte Energia, o que os coloca, em quase todas as situações, em condição de extrema fragilidade.

Portanto, as relações com os brancos não são unicamente produtivas e positivas nem apenas conflituosas e suspeitas; elas são tudo isso ao mesmo tempo; relações de amizade e parceria não se dão sem desconfiança e animosidade. Esse mesmo mecanismo é suplantado para a relação que os Asuriní estabelecem com a fotografia, nem apenas positiva nem unicamente negativa, mas positiva $e$ negativa ao mesmo tempo, a ambivalência entre os polos sendo a regra. A ambivalência das imagens técnicas reside no fato de que podem capturar o ynga da pessoa retratada. Assim, fotografias podem oferecer riscos na medida em que são um objeto que imita a pessoa, e que, por isso, se coloca em relação de contigüidade com seu modelo, partilhando o seu princípio vital. No caso da imagem da televisão, do vídeo e do filme, a relação que se estabelece é com o ynga enquanto sombra e voz. A sombra de um corpo no chão é, de certa forma, um efeito projetivo do princípio vital animado; no entanto, a sombra separada do corpo também pode remeter aos espectros anhynga, principalmente se a imagem em movimento for de uma pessoa já falecida. Voz e imagens (em movimento e estáticas) separadas do corpo apontam para estados de desintegração ou separação das partes que constituem uma pessoa, o que se vive em ocasiões de adoecimento, morte, ou pelos pajés nas ações rituais e durante os sonhos, momentos em que se deve ter muito cuidado e precaução para que conseqüências negativas não sejam sentidas.

Relações ambíguas são vividas também com os espíritos. O contato com eles durante os maraká é ameaçador pois se comportam como animais - devem ser aprisionados, matam, agridem -, mas participam, também, das atividades da aldeia, dançando, fumando e tomando mingau. Dessa maneira, a relação tensa e conflituosa é, de outro lado, uma relação de troca: ao espírito se oferece tabaco e mingau, e ele fornece aos humanos o ynga e o moynga.

É ambígua a própria condição dos xamãs. Durante os rituais eles se metamorfoseiam nos espíritos e se tornam um deles, perdem os sentidos ("morrem", dizem os Asuriní) nos maraká terapêuticos associados aos Apykwara, Karovara e Tivá, ou corporificam e os trazem para a terra se comportando como 
um deles durante os rituais propiciatórios ligados à caça e à agricultura, associados aos Tajaho e aos Arapuá. Outra situação que reafirma a condição ambivalente do xamã ocorre durante o sono, quando seu duplo (ynga) viaja aos mundos dos espíritos, locais em que o xamã é socializado: ganha um nome, casase, tem filhos.

O que estou chamando aqui de ambigüidade é referido por Müller como a relação de equivalência sem oposição, de isso e aquilo, que é operativa na relação dos Asuriní com os seus Outros. A autora diz: "[...] se há a relação com o mundo exterior, fundamento da diferença como condição da sociedade, ela está na concomitância, simultaneidade de estados de alteridade" (Müller, 1993, p. 279, grifo da autora). Parece-me que, a respeito desta noção filosófica, o xamanismo é um importante modelo; é da condição do xamã de ser, ao mesmo tempo, espírito e humano que deriva a ideia de par, isso e aquilo sem hierarquização ${ }^{136}$. E, dessa maneira, diz Müller, "[a] par dessa função desempenhada pelo xamã, a representação estética também opera neste nível fazendo equivaler representação e realidade [...]" (Op. cit., Ibid.).

Por outra via, procurei mostrar que a relação entre um modelo ou um referente e sua imagem passa longe de ser a de representação do que está ausente, mas, antes, aponta para uma noção de imagem viva em que o objeto que imita evoca o modelo, estabelecendo uma relação de contigüidade com ele, ou simplesmente é parte do referente ou seu duplo. O que Müller chama de "equivalência entre representação e realidade sem hierarquização" pode ser levado mais além, pois a imagem não apenas "equivale ao real" mas o produz; ela "faz existir". Narrativas fílmicas "fazem existir universos virtuais", e agem de forma produtiva e fértil, comparadas às narrativas dos xamãs aos mundos dos espíritos nos ritos petymojap. Imagens fotográficas do passado trouxeram os antigos para as aldeias através de lembranças e memórias.

\footnotetext{
${ }^{136} \mathrm{~A}$ ambivalência é também a marca dos anhynga. Como dono do desenho, anhynga se refere à multiplicidade e à presença. Multiplicidade de desenhos no corpo de Anhyngakwasiat que não obedecem às regras de divisão da anatomia do corpo nem de gênero (como fazem os Asuriní). E enquanto espectros dos mortos, anhynga se refere à ausência e divisão. Para uma análise mais aprofundada a respeito desse aspecto ver Müller, 2013.
} 
Voltando ao tema da ambivalência, poderíamos dar outros exemplos da ambigüidade da relação dos Asuriní com essas novas imagens. Argumentamos no início que o polo positivo parece prevalecer nos dias de hoje; no entanto, a qualquer momento fotografias podem oferecer riscos, haja vista que o tabu em relação a imagens de recém-falecidos permanece. 0 que estou querendo dizer é que o que parece caracterizar o processo de mais de quarenta anos de contato com essas novas imagens não é a passagem do registro negativo ao positivo, mas um continuum em que permanecem agências, usos e relações ambíguas com fotografias - o que, creio, pode se estender também a filmes e vídeos -, ora pesando mais para um lado, ora mais para outro. E a ambiguidade, se na relação com essas imagens se conservou desde o contato, não se manteve presente da mesma maneira; muita coisa mudou ao longo dos anos.

De fato, os Asuriní vivem hoje uma realidade muito diferente do que experimentavam há quarenta anos. Apenas no que diz respeito ao contato com as imagens técnicas, uma mudança grande pode ser observada nos últimos dez anos. Desde que iniciei meus trabalhos junto aos Asuriní em 2006, assisti à proliferação de aparelhos televisores nas aldeias. No início de minhas pesquisas a aldeia contava apenas com um aparelho que ficava sob a guarda do xamã Mure'yra, em sua casa. Atualmente, todas as 33 residências asuriní contam com pelo menos um aparelho equipado com DVD; não raro, encontramos residências com dois televisores. Outro fenômeno recente é a aquisição de aparelhos celulares que filmam e fotografam, o que foi possível graças ao montante financeiro que entrou na aldeia referente às compensações da usina de Belo Monte. Quanto a câmeras filmadoras, verifiquei a existência de duas na minha última ida a campo; no entanto, os Asuriní as utilizam apenas em ocasiões esporádicas, para registrar reuniões importantes, e ainda assim com muita dificuldade no manejo técnico. E isso tudo sem falar nos diversos pesquisadores e equipes de trabalho que passaram pela aldeia ao longo dos anos portando máquinas filmadoras e fotográficas para a produção de mais imagens sobre os Asuriní.

Poderíamos pensar que o peso do polo positivo na relação com as imagens técnicas tem forte ligação com o fato de que eles se acostumaram a viver 
em meio aos brancos, produtores de imagens na aldeia, e em meio às imagens de "fora", que chegam via televisores e filmes que são trazidos por parceiros e pesquisadores, ou que eles mesmos adquirem na cidade de Altamira. Mas há outro aspecto importante na consideração da diminuição do risco e do perigo no trato com as imagens técnicas nos dias de hoje. 0 xamanismo, que está na base da ideia da fotografia como objeto patogênico, encontra-se em declínio. E este ponto tem consequências, não apenas na relação entre os Asuriní e novas imagens, mas também na relação dos índios com seus Outros (brancos e espíritos), o que gera implicações profundas na manutenção e na produção da vida asuriní.

É preciso notar que o declínio do xamanismo, não apenas diminui o risco associado às imagens técnicas, mas, sim, afeta sua agência de uma maneira geral, da qual decorre o entendimento dessas imagens como "coisa viva". Dessa maneira, não seria o caso de dizer que o polo positivo ganha espaço nos dias atuais, mas de constatar que o que perde força é a capacidade das imagens em agenciar relações e provocar efeitos, sejam positivos ou negativos. Tal colocação poderia ser contra-argumentada por tudo que procurei mostrar no capítulo 4, ao descrever o modo como as fotografias dos antigos agiram ao evocar a presença dos parentes via memórias e imagens. No entanto, esses efeitos foram verificados principalmente entre os velhos que tinham alguma ligação de parentesco com as pessoas retratadas, e, além disso, a presença dos parentes se fez ainda mais forte na residência do casal Marakauá e Mure'yra, que se dispuseram a ver a totalidade das imagens. Mure'yra é, sem dúvida, o maior xamã que os Asuriní tiveram nos últimos tempos, e foi justamente em sua residência que fotografias puderam evocar de forma potente os parentes e, ao mesmo tempo, oferecer algum perigo; o xamã foi o único que expressou o risco de ficar triste, ao ver a fotografia de uma de suas ex-esposas.

Como bem mostrou Müller, nos anos pós-contato, o processo de extinção física se fez acompanhar de extrema vitalidade cultural, manifesta no aumento dos extensos rituais xamanísticos. Entre 1976 e 1982, havia 12 xamãs numa população de 55 indivíduos, ou seja, um xamã para cada quatro pessoas. A autora demonstrou em alguns trabalhos, $(1993,2000$, etc.) como a convivência amistosa 
e ameaçadora com alteridades diferentes (brancos e espíritos) é vivida na ação ritual, estando prevista na cosmologia. Um bom exemplo foi um ritual xamanístico que ocorreu em 1993, quando os Asuriní invocaram espíritos ferozes diante de um público diverso, o que incluiu os próprios índios, mas também funcionários da Funai, missionários católicos e evangélicos, a antropóloga Müller, além de índios Arara e Kararaô. No início da década de 1990, o povo vivia novos desafios na relação com os brancos e esta convivência amistosa e agressiva foi vivida na ação ritual (Müller, 2000, p. 174).

O declínio do xamanismo também tem sido pensado pelos Asuriní. Na minha última incursão ao campo, verifiquei que preocupações e reflexões referentes a esse tema foram muito presentes, principalmente nas conversas com os jovens professores e com as jovens lideranças das aldeias. Na tentativa de fazer que eu compreendesse as histórias que seu pai, o falecido xamã Kurijá, contava, Koain, liderança da aldeia Ita'aka, disse: "Se só falar assim, vira lenda, mas se pajé conta, ele está vendo". Como argumentamos, o xamã vê e vive, experimenta e se metamorfoseia nos espíritos ao integrar seus mundos e, quando conta suas narrativas, fala de uma experiência em primeira pessoa. Foi muito elucidativo o comentário de Koain de que as narrativas, sem o conhecimento prático e a narração do xamã, estão fadadas a virar "lenda", histórias genéricas de um passado, transmitidas pela tradição, mas desprovidas da dimensão da experiência.

Nos dias de hoje, há três xamãs entre os Asuriní: Mure'yra, de 85 anos, Boaiva, de 70, e Parajuá, de 30. Contudo, nenhum dos três tem se dedicado muito ao xamanismo; os dois primeiros, em razão da idade, e o jovem, por falta de interesse e estímulo. Como dizem os Asuriní, é muito difícil alguém novo se interessar em ser xamã. Koain explica: "O pessoal fica muito na cidade, lá é muito iluminado, faz mal pra ele, e fica difícil para espírito". Além disso, o índio avalia que é muito conhecimento (kuakuava) e muita dedicação que a pessoa tem que ter para ser pajé, e os jovens não têm nem interesse nem tempo disponível para uma atividade desse tipo.

Diante desse contexto, Koain se mostrou preocupado. Ele disse que, antes, os pajés "regulavam as coisas", do que apreendo que estava se referindo tanto à 
ordem cósmica quanto à ordem das relações e à boa gerência da vida na aldeia, esta última, função a que ele, como jovem liderança, dedica-se atualmente. Além disso, o jovem disse que os xamãs eram responsáveis pelo cumprimento das regras (apakatuté, "fazer direito") de antigamente - em outro contexto ele se refere às "regras" pelo termo aereka, "nosso jeito" -, que, segundo o índio, eram extremamente rígidas. Para Koain, a ausência de pajés é um dos fatores responsáveis pelo fato de os novos estarem sem direção. Ele afirma: "A minha preocupação é tomar o rumo das coisas". Ele se refere, sobretudo, ao fato de muitos jovens estarem bebendo cachaça nas freqüentes visitas à cidade de Altamira. Contudo, pondera: "Nosso jeito [aereka] tá mudando, mas tem alguns costumes que não podem mudar, por exemplo, comer junto, fazer mingau, fazer a tavyve para enterrar os mortos. 0 que eu não quero é que eles virem akaraí, que outro pense que eles são akaraí".

No depoimento transcrito acima, Koain expressa uma questão que tem rondado os Asuriní e, por mais paradoxal que ela possa parecer ${ }^{137}$, está presente no cotidiano e nas reflexões, principalmente dos jovens, a respeito "do rumo que as coisas estão tomando", para usar uma expressão do próprio índio. Hoje há seis casamentos entre Asuriní e brancos. Essa prática é uma novidade, o que pode ser constatado com o dado de que três desses seis casamentos aconteceram nos últimos seis meses. Obviamente, os Asuriní que estão casando com brancos são jovens ${ }^{138}$. Para os velhos, essas alianças são impensáveis. Veveí afirma: "Asuriní quer morrer casando tudo akaraí". Para aqueles que testemunharam o contato e que consideravam os brancos inimigos (tapy'yia) até pouco tempo, essas alianças podem ser perigosas. A figura ambígua do branco, entre inimigo e aliado, gera insegurança, principalmente nos velhos.

Parece evidente que o declínio do xamanismo se faz acompanhar de muitas outras mudanças, especialmente no que concerne à transmissão de conhecimentos diversos. Refletindo sobre o que muda e o que permanece,

\footnotetext{
137 Quem visita as aldeias pode constatar que eles estão muito distantes de se "transformarem" em brancos, independente do que isto possa significar. Mas adentrar a questão por aí é um caminho sem volta. Não nos interessa avaliar e julgar o processo que eles estão vivendo, apenas reconhecer que reflexões a esse respeito estão presentes. 138 São três mulheres e três homens casados com brancos. A maior parte deles tem até 20 anos.
} 
Koatireí, jovem professor, comenta: "Antes aprendia ouvindo histórias nas casas e na festa, na festa todo mundo participava. Hoje não acontece assim". Um dos motivos de os novos não conhecerem as histórias e as festas asuriní é que "[...] hoje casam cedo e vão pra 'casinha', só alguns convivem com os mais velhos, só alguns têm curiosidade. A festa acontece poucas vezes e, quando tem, quase ninguém vai". As crianças estão falando majoritariamente português, exceto as poucas que residem com avós ou idosos. A convivência com idosos no âmbito doméstico tende a diminuir cada vez mais, e, embora diferentes gerações convivam no contexto de outros espaços em que circulam pessoas de um mesmo grupo doméstico - como as "cozinhas" externas destinadas ao preparo de alimentos e às refeições -, é extremamente reduzido o número de velhos vivos (treze velhos, seis residindo no Ita'aka e sete no Koatinemo). Além disso, muitos deles, que já são viúvos ou não têm cônjuge, moram sozinhos, com um ou dois parentes, o que, na verdade, segue a lógica atual dos Asuriní de que cada família nuclear tenha sua própria residência.

Diante de todas essas mudanças, pode ser que imagens e sons produzidos pelas tecnologias dos brancos, num futuro próximo, entrem em cena para desempenharem novos papéis. Espero que a promissora apropriação asuriní da produção audiovisual possa nos surpreender com renovados usos das imagens. $\mathrm{Ou}$, ainda, que os extensos registros de rituais dos antigos possam voltar a circular novamente, o que vai acontecer, ao que tudo indica, ou pelo menos se depender da vontade de Veveí, índia de 65 anos que me disse no último campo: "Agora não tem mais pajé, então traz pendrive pra mim". Mas não é operando a transmissão dos saberes no lugar dos conhecimentos incorporados que as imagens e sons têrm força. Dentre os múltiplos agenciamentos que promovem, imagens do passado são "boas para lembrar". Como observei em campo, o ato de rememorar o passado gera, inevitavelmente, reflexões sobre o que muda e o que permanece, e sobre os novos rumos que estão tomando como povo. Almejo que as imagens e os sons dos antigos, bem como a produção de outras imagens em diferentes formatos e suportes, possam alimentar a criatividade dos Asuriní que precisam, ao mesmo tempo, garantir a produção continuada de sua maneira de estar no mundo e inventar outras formas de relação com seus Outros, diante dos desafios colocados pelos novos interlocutores. 


\section{REFERÊNCIAS BIBLIOGRÁFICAS}

ALBERT, B. "Images, traces et 'hyper images': impromptu d'ethnographie noctambule". Imagine ambulat homo Augustin. La Trinité, livre XIV, 4, 6, p.1 e ss, s/d. Disponível em: http://www.ctrlab.inf.br/reflexao.html. Acesso em set. de 2015.

"Introdução: cosmologias do contato no Norte-Amazônico". In: ALBERT, B.; RAMOS, A. R. (Orgs.). Pacificando o Branco. Cosmologias do Contato no NorteAmazônico. São Paulo: Editora Unesp, 2000, p. 9-21.

ALBERT, B.; RAMOS, A. R. (Orgs.). Pacificando o Branco. Cosmologias do Contato no Norte-Amazônico. São Paulo: Editora Unesp, 2000.

APPADURAI, A. (Ed.). A Vida Social das Coisas: As mercadorias sob uma perspectiva cultural. Tradução de Agatha Bacelar. Niterói: Eduff, 2008[1986].

BAKEWELL, L. "Image acts". American anthropologist, v. 100, nº. 1, p. 22-32, 1998.

BANKS, M.; MORPHY, H. Rethinking Visual Anthropology. New Haven, CT, Yale: University Press, 1997.

BARCELOS NETO, A. "O universo visual dos xamãs wauja (Alto Xingu)". Journal de la société des américanistes, Paris, v. 87, p. 137-160, 2001.

Apapaatai: rituais de máscaras no Alto Xingu. São Paulo: Edusp, 2008.

BARTHES, R. A câmara clara. Rio de Janeiro: Nova Fronteira, 1984.

BAXANDALL, M. Painting and experience in fifteenth century Italy. Oxford: Oxford University Press, 1988.

BAZIN, A. "Ontologia da imagem fotográfica”. In: Xavier, I. (Org.). O cinema Ensaios. São Paulo: Editora Brasiliense, 1991[1945], p. 19-26.

BELTING, H. Pour une anthropologie des images. Tradução de Jean Torrent. Paris: Gallimard, 2004[2001].

BRUNO, F. Fotobiografia. Por uma metodologia estética em antropologia. 2009. Tese (Doutorado em Multimeios) - Programa de Pós-Graduação em Multimeios, Instituto de Artes da Universidade Estadual de Campinas, Campinas, 2009.

BUENO, A. C. V. Fios de memórias. Um estudo sobre parentesco e história a partir da construção da genealogia manoki (irantxe). 2015. Tese (Doutorado em Antropologia Social) - Programa de Pós-Graduação em Antropologia Social da Faculdade de Filosofia, Letras e Ciências Humanas da Universidade de São Paulo, São Paulo, 2015. 
CAIUBY NOVAES, S. Jogo de espelhos - imagens da representação de si através dos outros. São Paulo: Edusp, 1993.

. "Imagem, magia e imaginação - desafios ao texto antropológico". Mana, Rio de Janeiro, v. 14, p. 455-475, 2008.

. "Apresentação". In: (Org.). Entre arte e ciência. A fotografia na antropologia. São Paulo: Edusp, 2015. p. 9-20.

CARNEIRO, R. "Recent observations on shamanism and witchcraft among the Kuikuro indians of Central Brazil". Annals of the New York Academy of Sciences, Nova York, v. 293, p. 215-228, 1977.

CARNEIRO DA CUNHA, M. Os mortos e os outros. São Paulo: Hucitec, 1978.

"Pontos de vista sobre a floresta amazônica: xamanismo e tradução". Mana, Rio de Janeiro, v. 4, n. 1, p. 7-22, 1998.

. Cultura com aspas. São Paulo: Cosac Naify, 2009.

CESARINO, P. N. "A escrita e os corpos desenhados: transformações do conhecimento xamanístico entre os Marubo". Revista de Antropologia, São Paulo, v. 55, n. 1, p. 75-137, 2012. Disponível em:

<http://www.revistas.usp.br/ra/article/view/47583>. Acesso em 25 de maio de 2014.

COLLIER, J. Antropologia visual: a fotografia como método de pesquisa. São Paulo: EPU/Edusp, 1973.

COUDREAU, Henri. Viagem ao Xingu. São Paulo: Ed. Itatiaia/Edusp, 1977 [1897].

CUNHA, E. B.; FERRAZ, A. L.; HIKIJI, R. S. “O vídeo e o encontro etnográfico". Cadernos de Campo, São Paulo, v. 15, n. 14/15, p. 287-297, 2006.

DA MATTA, R. Apinayé. Um mundo dividido. Petrópolis: Editora Vozes, 1976.

DEBRAY, R. Vie e mort de l' image. Une histoire du regard en Occident. Paris: Gallimard, 1992.

DELAPLACE, G. "Retoucher les morts, les usages magiques de la photographie en Mongolie". Terrain, Paris, n. 62, p. 138-151, 2014.

DÉLÉAGE, P. “Les répertoires graphiques amazoniennes”. Journal de la Société des Américanistes, Paris, v. 93, n.1, p. 97-126, 2007.

DESCOLA, P. Par-delà nature et culture. Paris: Éditions Gallimard, 2005. 
. "La fabrique des images". Anthropologie et sociétés, Paris, v. 30, n. 3, p. 167-182, 2006.

La fabrique des images. Visions du monde et formes de la représentation: catálogo. Paris: Musée du Quai Branly, 2010. (Catálogo de exposição).

DUBOIS, P. $O$ ato fotográfico e outros ensaios. Tradução de Marina Appenzeller. 14a. edição. Campinas: Editora Papirus, 2014[1990].

EDWARDS, E.; HART, J. (Eds.). Photographs Objects Histories. On the Materiality of Images. London: Routledge, 2004.

FIGUEIREDO, M. V. A flecha do ciúme. O parentesco e seu avesso segundo os Aweti do Alto Xingu. 2010. Tese (Doutorado em Antropologia Social) - Programa de Pós-Gradução em Antropologia Social do Museu Nacional/UFRJ, Rio de Janeiro, 2010.

FREEDBERG, D. The power of images. Studies in the history and theory of response. Chicago e Londres: The University of Chicago Press, 1989.

GALLOIS, Dominique. O movimento na cosmologia Waiãpi: criação, expansão e transformação do universo. 1988. Tese (Doutorado em Antropologia) - Programa de Pós-Graduação em Antropologia Social da Faculdade de Filosofia, Letras e Ciências Humanas da Universidade de São Paulo, São Paulo, 1988.

GALLOIS, D; CARELLI, V. "Vídeo nas Aldeias: a experiência Waiãpi”. Cadernos de Campo, São Paulo, v. 2, n. 2, p. 25-36, 1992.

GALVÃO, E. "Áreas culturais indígenas do Brasil: 1900 - 1959". Boletim do Museu Paraense Emílio Goeldi, Belém, no 8, 1960. (Nova Série Antropologia).

GARCIA, U. F. Karawara a caça e o mundo dos Awá-Guajá. 2010. Tese (Doutorado em Antropologia Social) - Programa de Pós-Graduação em Antropologia Social da Faculdade de Filosofia, Letras e Ciências Humanas da Universidade de São Paulo, São Paulo, 2010.

GELL, A. Art and agency: an anthropological teory. Oxford: Clarendon Press, 1998. "A tecnologia do encanto e o encanto da tecnologia". Concinnitas. Tradução de Jason Campelo. Rio de Janeiro, ano 6, v. 8, n. 1, p. 40-63, 2005[1992].

GONÇALVES, M. A. "De Platão ao photoshop: as imagens e suas leituras". Ciência Hoje, Rio de Janeiro, v. 298, p. 12-17, 2010.

GONÇALVES, M. A.; HEAD, S. C. (Orgs). Devires imagéticos - Representações / apresentações de si e do outro. Rio de Janeiro: 7 Letras, 2009. 
GORDON, C. Economia Selvagem. Ritual e mercadoria entre os índios XikrinMebêngôkre. São Paulo: Editora da Unesp, 2006.

GOW, P. "Cinema da floresta: filme, alucinação e sonho na Amazônia peruana". Revista de Antropologia. Tradução de Heloisa Buarque de Almeida. São Paulo, v. 38, n. 2, p. 37-54, 1995.

. "Da etnografia à história: 'Introdução' e 'Conclusão' de Of Mixed blood: kingship and history in peruvian Amazônia". Cadernos de campo. Tradução de Andrade, A. M. C.; Collevatti, J. H.; Andrade, H. M. São Paulo, v. 15, n. 14/15, p. 197-226, 2006.

LAGROU, E. “Antropologia e arte: uma relação de amor e ódio". Ilha, Florianópolis, v. 5, n. 2, p. 93-113, 2003.

A fluidez da forma: arte, alteridade e agência em uma sociedade amazônica (Kaxinawa, Acre). Rio de Janeiro: Topbooks, 2007.

. "Le graphisme sur les corps amérindiens: des chimères abstraites?". Gradhiva, Paris, n. 13, p. 69-93, 2011.

2013. "Podem os grafismos ameríndios ser considerados quimeras abastratas? Uma reflexão sobre uma arte perspectivista". In: Lagrou. E.; Severi, C. (Orgs). Quimeras em diálogo - grafismo e figuração na arte indígena. Rio de Janeiro: Editora 7 Letras, 2013. p. 67-109.

LARAIA, R. B.; DA MATTA, R. Índios e castanheiros: a empresa extrativista e os índios no médio Tocantins. São Paulo: Difusão Européia do Livro, 1967. 254p. (Coleção Corpo e Alma do Brasil).

LÉVI-STRAUSS, C. O cru e o cozido: Mitológicas I. Tradução de Beatriz PerroneMoisés. São Paulo: Cosac Naify, 2004[1964].

LUKESCH, A. "Über das Sterben bei den nördlichen Kayapó-Indianern". Anthropos, Fribourg, v. 51, p. 968-984, 1956.

. Mythos und leben der Kayapó. Viena: E. Stiglmayr, 1968. 316 p. (Séries: Acta ethnologica et linguistica).

Bearded indians of the tropical forest. The Asurini of the Ipiaçaba. Notes and observations on the first contact and living together. Austria: Graz Akademische Druck - u. Verlagsanstalt, 1976. 147 p.

MADI DIAS, D. "Três paradigmas para pensar o vídeo entre os Kayapó". Catálogo Fórum Doc BH 2011. Belo Horizonte: Ministério da Cultura, Filmes de Quintal e Ufmg, 2011. p. 300-328. (Catálogo de festival de cinema). 
MARESCA, S. La photographie - Un miroir des sciences sociales. Paris: L'Harmattan, 1996.

MARTINS, J. S. Sociologia da fotografia e da imagem. São Paulo: Editora Contexto, 2008.

MAUSS, M. "Esboço de uma teoria geral da magia". In: . Sociologia e Antropologia. São Paulo: Cosac \& Naify, 2004[1904].

MENEZES BASTOS, R. "O Payemeramaraká kamayurá: uma contribuição à etnografia do xamanismo no Alto Xingu". Revista de Antropologia, São Paulo, v. 27/28, p. 139-177, 1984-1985.

MILLER, D. Material Culture and mass consumption. Oxford: Basil Blackwell Ltd., 1987.

MIRANDA, X. B. 2014. Kunumi rukara: uma etnografia dos terreiros de criança asuriní. Dissertação (Mestrado em Antropologia Social). Programa de PósGraduação em Antropologia Social da Universidade Federal de São Carlos, São Carlos, 2014.

MITCHELL, W.J.T. Iconology - image, texte, ideology. Chicago: The University of Chicago Press, 1986.

MONSERRAT, Ruth; JESUS, Irmãzinhas. Língua asuriní do Xingu. Observações gramaticais. Altamira: Prelazia do Xingu e Conselho Indigenista Missionário, 1998.

MOREIRA LEITE, M. Retratos de família. 3a edição. São Paulo: Edusp, 2001 [1993].

MÜLLER, R. A pintura do corpo e os ornamentos xavante: arte visual e comunicação social. 1976. Dissertação (Mestrado em Antropologia Social) Programa de Pós-Graduação em Antropologia Social do Instituto de Filosofia e Ciências Humanas da Universidade Estadual de Campinas, Campinas, 1976.

"Denúncia à Funai". São Paulo: 1977. Veja, São Paulo, n. 472, p. 65-66, 21 de set. 1977. Entrevista concedida à revista.

. "Assurini: intimidade com o sobrenatural". Brasília: 1979. Revista de Atualidade Indígena, Brasília, ano 3, no 19, p. 10-19, nov./dez. 1979. Entrevista concedida à revista.

26-43, 1980. 

1984/85.

“Asuriní do Xingu". Revista de Antropologia, São Paulo, v. 27/28, p. 91-114, De como cincoenta e duas pessoas reproduzem uma sociedade indígena: os Asurini do Xingu. 1987. Tese (Doutorado em Antropologia Social) - Programa de Pós-Graduação em Antropologia Social da Faculdade de Filosofia, Letras e Ciências Humanas da Universidade de São Paulo, São Paulo, 1987.

. "Tayngava, a noção de representação na arte gráfica Asuriní do Xingu". In: VIDAL, L. (Org). Grafismo Indígena - Estudos de Antropologia Estética. São Paulo: Edusp, 1992, p. 231-248. $\overline{1993 .}$.

Asuriní do Xingu, história e arte. 2a. edição. Campinas: Editora da Unicamp, . "Maraká, ritual xamanístico dos Asuriní do Xingu”. In: Langdon, J. (Org.). Xamanismo no Brasil: novas perspectivas. Florianópolis: Editora da UFSC, 1996.

. "Corpo e imagem em movimento: há uma alma nesse corpo". Revista de Antropologia, São Paulo, v. 43, no 2, p. 165-193, 2000.

"As crianças no processo de recuperação demográfica dos Asuriní do Xingu". In: Lopes da Silva, A.; Macedo, A. V.; Nunes, A. (Orgs). Crianças Indígenas, ensaios antropológicos. São Paulo: Global Editora, 2002. p. 188-209.

"Danças indígenas: arte e cultura, história e performance". In: Ligiéro, Z; Dos Santos, C. A. Dança da terra. Rio de Janeiro: Ed. Papel Virtual, 2005. p. 13-27.

"Arte gráfica Asuriní do Xingu: corpo, mito e pensamento". In: Lagrou. E.; Severi, C. (Orgs). Quimeras em diálogo - grafismo e figuração na arte indígena. Rio de Janeiro: Editora 7 Letras, 2013, p. 163-180.

MÜLLER, R.; DELAROLE, R.; LABONIA FILHO, W. Project of health recuperation for the "Asuriní" indians of Koatinemo (Brazil). São Paulo: IWGIA, 1986. Relatório endereçado à IWGIA e ao Ministério das Relações Exteriores da Dinamarca.

NIMUENDAJÚ, C. "Tribes of the lower and middle Xingu river". In: Steward, J. (Ed.). Handbook of south american indians. Washington D.C.: Smithsonian Institute / Bureau of American Ethnology, v. 3, Bulletin 143, 1948.

PELLEGRINO, S. Imagens e substâncias como vínculos de pertencimento: as experiências Wajãpi e Yanomami. 2008. Tese (Doutorado em Antropologia Social) - Programa de Pós-Graduação em Antropologia Social da Faculdade de Filosofia, Letras e Ciências Humanas da Universidade de São Paulo, São Paulo, 2008. 
PLATÃO. "Crátilo". In: Diálogos. Tradução de Carlos Alberto Nunes. V. IX. Belém: Universidade Federal do Pará, 1973. (Coleção Amazônica).

RÉUNION DES MUSÉES NATIONAUX (França). Brésil indien. Les arts des Amérindiens du Brésil: catálogo. Paris: Galeries nationales du Grand Palais, 2005. Catálogo de exposição.

RIBEIRO, B. "A oleira e a tecelã: o papel social da mulher na sociedade asuriní". Revista de Antropologia, São Paulo, v. 25, p. 25-61, 1982.

. "Tecelãs tupi do Xingu". Revista de Antropologia, São Paulo, v. 27/28, p. 355-402, 1984-85.

RIBEIRO, D. "Indigenous cultures and languages of Brazil". In: Hopper, J. H. (Ed.). Indians of Brazil in the twentieth century. Washington: Institute for CrossCultural. Research, 1967, p. 77-168.

ROUILLÉ, A. A Fotografia entre documento e arte contemporânea. São Paulo: Editora SENAC, 2009.

SAHLINS, M. "O 'pessimismo sentimental' e a experiência etnográfica: por que a cultura não é um 'objeto' em via de extinção (Parte II)". Mana, Rio de Janeiro, v. 3, n. 2, p. 103-150, 1997.

SCHADEN, E. "Aculturação indígena. Ensaio sobre fatores e tendências da mudança cultural de tribos índias em contato com o mundo dos brancos". Revista de Antropologia, São Paulo, v. 13, p. 1965.

SCHAEFFER, J-M. Les célibataires de l'art. Pour une esthétique sans mythes. Paris: Gallimard, 1996.

SEVERI, C. "Warburg Anthropologue, ou le déchiffrement d'une utopie. De la Biologie des images à l'Anthropologie de la mémoire". L'Homme, Paris, n. 165, p. 77-129, 2003.

SILVA, F. A. As Tecnologias e Seus Significados. Um estudo da cerâmica dos Asurini do Xingu e da cestaria dos Kayapó-Xikrin sob uma perspectiva Etnoarqueológica. 2000. Tese (Doutorado em Antropologia Social) - Programa de Pós-Graduação em Antropologia Social da Faculdade de Filosofia, Letras e Ciências Humanas da Universidade de São Paulo, São Paulo, 2000.

. Cultura material e dinâmica cultural: um estudo etnoarqueológico sobre os processos de manutenção e transformação de conjuntos tecnológicos entre os Asuriní do Xingu. São Paulo: MAE/ USP, 2005. Projeto de pesquisa apresentado à Fapesp. 
SOUZA, M. L. R. 1994. Nomes e história do contato entre os Asuriní do Xingu. Dissertação (Mestrado em Antropologia Social) - Programa de Pós-Graduação em Antropologia Social da Faculdade de Filosofia, Letras e Ciências Humanas da Universidade de São Paulo, São Paulo, 1994.

TAUSSIG, M. Mimesis and alterity: a particular history of the senses. New York and London: Routledge, 1993.

TAYLOR, A. C. "Voir comme un Autre: figurations amazoniennes de l'âme et des corps". La fabrique des images. Visions du monde et formes de la représentation. Paris: Musée du Quai Branly, 2010. (Catálogo de exposição).

VAN VELTHEM, L. H. O Belo é a Fera- A estética da produção e da predação entre os Wayana. Lisboa: Museu Nacional de Etnologia Assírio e Alvim, 2003.

VERNANT, J. P. "A categoria psicológica do 'duplo'". In: Mito e Pensamento entre os Gregos. Tradução de Haiganuch Sarian. Rio de Janeiro: Ed. Paz e Terra, 1990[1973].

"Da presentificação do invisível à imitação da aparência". In: . Mito e Pensamento entre os Gregos. Tradução de Haiganuch Sarian. Rio de Janeiro: Ed. Paz e Terra, 1990[1973].

VIDAL, L.; LOPES DA SILVA, A. "Conclusão. Antropologia estética: enfoques teóricos e contribuições metodológicas". In. VIDAL, Lux (Org.). Grafismo Indígena. São Paulo: Nobel/ Fapesp/ Edusp, 1992.

VILLELA, A. Das Acontecências: experiência e performance no ritual Asuriní. 2009. Dissertação (Mestrado em Artes) - Programa de Pós-Graduação em Artes do Instituto de Artes da Unicamp, Campinas, 2009.

"Quando a imagem é a pessoa ou a fotografia como objeto patogênico. In: Caiuby Novaes, S. (Org.). Entre Arte e Ciência - A fotografia na Antropologia. São Paulo: Edusp, 2015.

VILLELA, A.; GRUNVALD, V. " Alguns apontamentos sobre fotografia, magia e fetiche". Publicação do projeto temático: "A experiência do filme na antropologia", São Paulo, 2015. No prelo.

VIVEIROS DE CASTRO, E. 1977. Indivíduo e sociedade no Alto Xingu: os Yawalapíti. Dissertação (Mestrado em Antropologia Social) - Programa de Pós- Graduação em Antropologia Social do Museu Nacional/UFRJ, Rio de Janeiro, 1977.

. Araweté: Os Deuses Canibais. Rio de Janeiro: Jorge Zahar Editores - Anpocs, 1986. 
_. A Inconstância da alma selvagem. São Paulo: Cosac \& Naify, 2002.

. "Perspectival anthropology and the method of controlled equivocation".

Tipití: Journal of the Society for the Anthropology of Lowland South America, v. 2, iss. 1 , p. 1-20, 2004.

"A floresta de cristal: notas sobre a ontologia dos espíritos amazônicos". Cadernos de Campo, São Paulo, v. 14/15, p. 319-338, 2006.

VON SIMSON, O. R. "Imagem e Memória". In: Samain, E. (Org). O Fotográfico. 2 $2^{\underline{a}}$ edição. São Paulo: Hucitec, 2005.

WAGLEY, C.; GALVÃO, E. The Tenetehara indians. A culture in transition. New York: Columbia- University-Press, 1949.

WOLFF, F. "Por trás do espetáculo - o poder das imagens". In: Novaes, A. (Org.), Muito além do espetáculo. São Paulo: Editora Senac, 2005. p.16-45.

WRIGHT, R. B. História Indígena e do indigenismo no Alto Rio Negro. São Paulo: Instituto Socioambiental - ISA, 2005.

\section{OUTRAS FONTES}

Documentos e acervos

DOCUMENTAÇÃO E TRANSMISSÃO DOS SABERES TRADICIONAIS DOS ASURINÍ DO XINGU. Campinas: Iphan/ Unicamp. 1 Kit Multimídia.

DELAROLE, R. Fotografias do acervo pessoal de Regina Müller. 750 fotografias, cor e PB. Campinas, 2015.

Filmes

Acontecências. Direção: Alice Villela e Hidalgo Romero. Campinas: Unicamp e Laboratório Cisco, 2009, 23 min, DVD, cor.

A Guerra do Fogo. Direção: Jean-Jacques Annaud. EUA: Twentieth Century Fox Film Corp, 1981, 100 min, cor. Título original: La Guerre du Feu.

Floresta do Mal - Caminhos da morte. Direção de Declan O’Brien. EUA: Fox Film do Brasil, 2009, 93 min, cor. Título original: Wrong Turn 3 - Left For Dead.

Morayngava. Direção: Regina Müller e Virgínia Valadão. São Paulo: CTI/ Vídeo nas aldeias, 1997, 16 min, NTSC, cor. 
O Brinquedo Assassino. Direção de Tom Holland. EUA, 87 minutos,1988. Título original: Child's Play.

Xapiri. Direção: Leandro Lima e Gisela Motta, Laymert Garcia dos Santos e Stella Senra, Bruce Albert. São Paulo: Cinemateca Brasileira, Instituto Socioambiental, Laboratório de Cultura e Tecnologia em Rede/i21, Hutukara Associação Yanomami, 2012, $54 \mathrm{~min}$. 
ANEXO 


\section{Terminologia de relação de parentesco ego feminino}

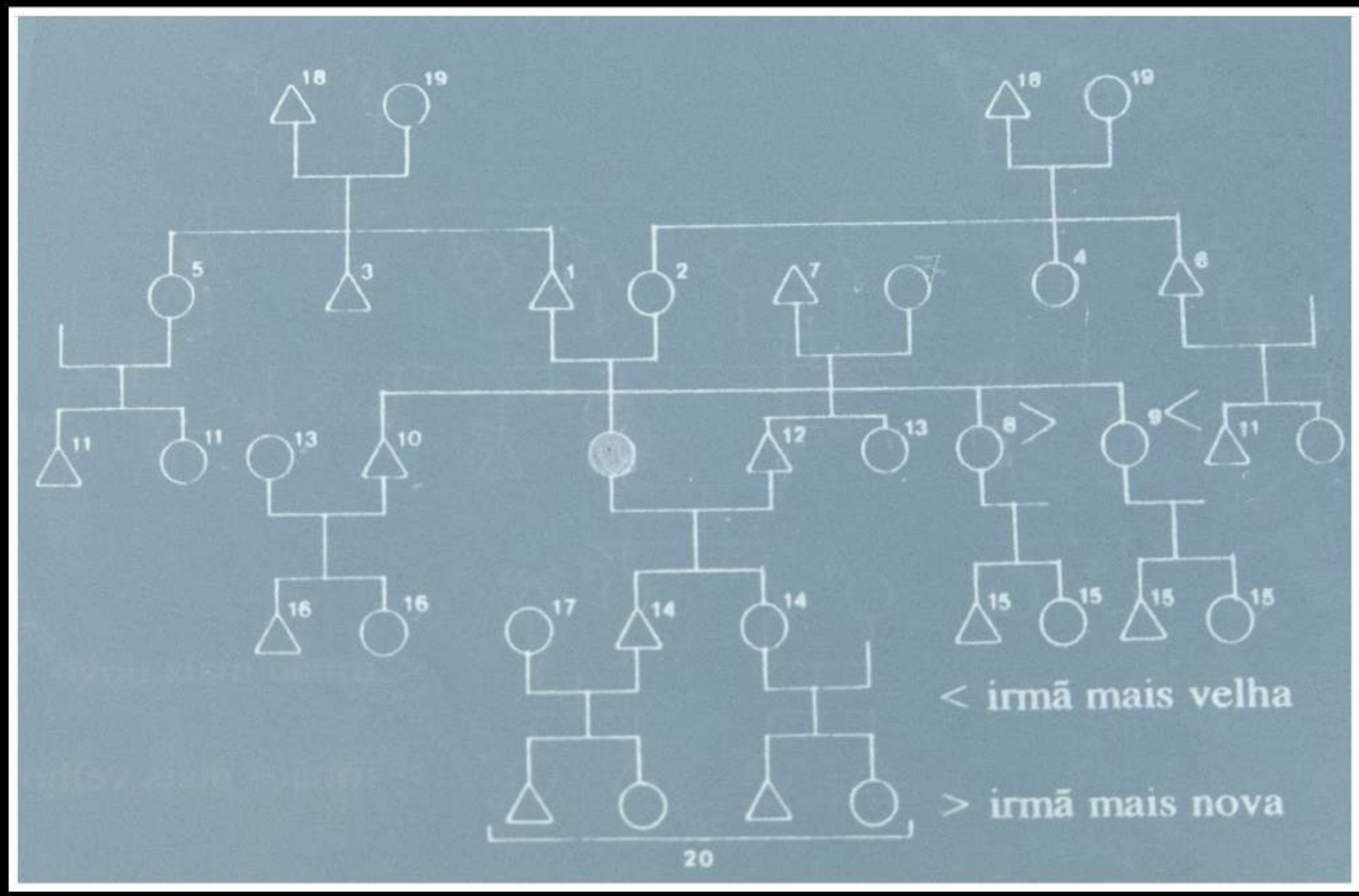

1 - jeruva

2 - jehy,mihi

3 - jeruvyra

4 - jehy'yra

5 - jajé
6 - jetutyra

7 - jeijara

8 - jerekyra

9 - jekypy'yra

10 - jekyvyra
11 - jesambere

12 - jererakwara

13 - jeokeí

14 - jemembyra

15 - oremembyra
16 - jepengí

17 - jemembytaty

18 - jeramũi

19 - jaryia

20 - jeremiarerũi 


\section{Terminologia de relação de parentesco ego masculino}

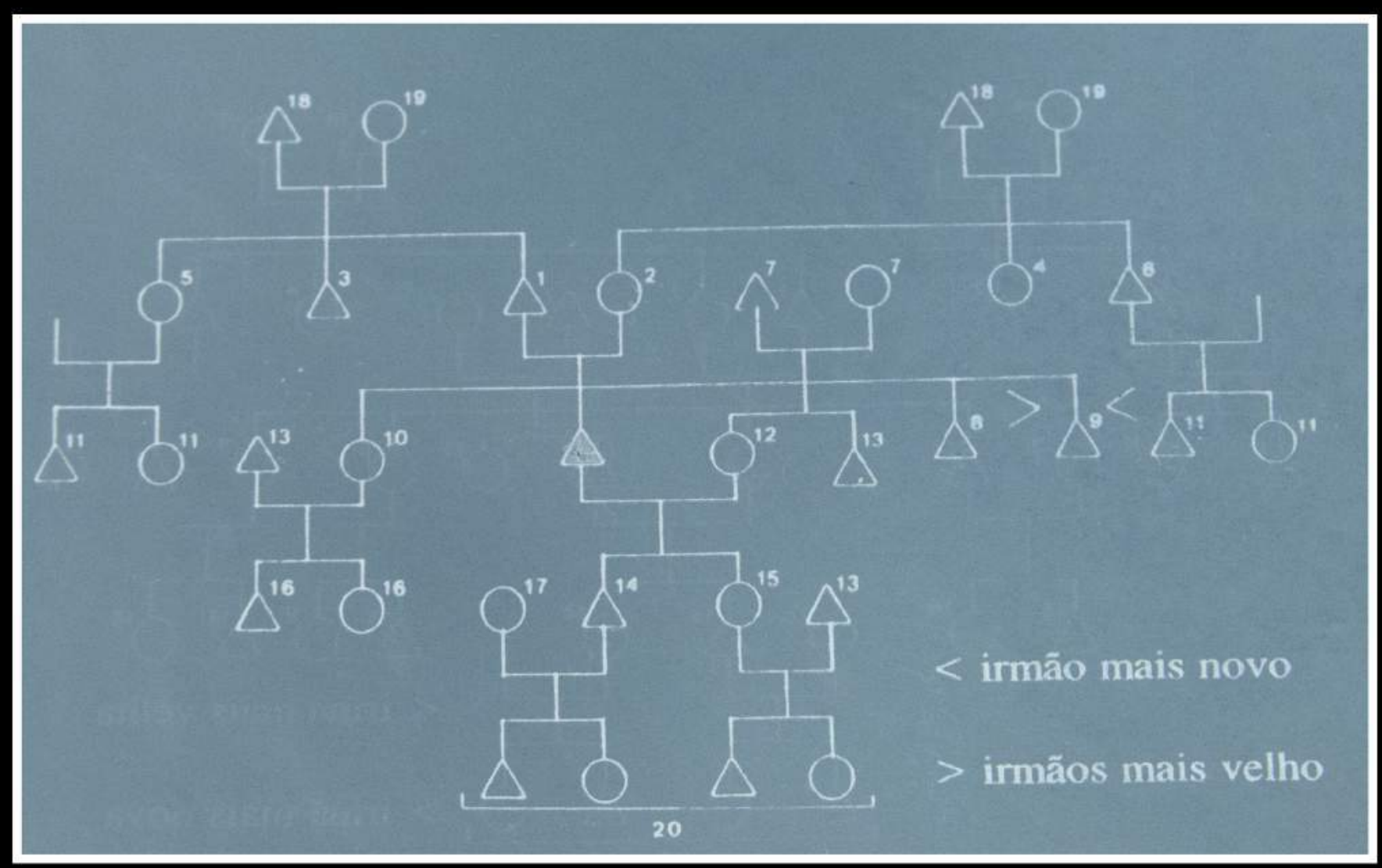

1 - jeruva

2 - jehy,mihi

3 - jeruvyra

4 - jehy'yra

5 - jajé
6 - jetutyra

7 - jeijara

8 - jeky'yra

9 - jeryvyra

10 - jerendyra
11 - jesambere

12 - jeremiriká

13 - jerayroyra

14 - jera'yra

15 - jerajira
16 - jekunhỹmembyra

17 - jera'ytaty

18 - jeramũi

19 - jaryia

20 - jeremominú 